UNIVERSIDADE DE SÃO PAULO

FACULDADE DE EDUCAÇÃO

A criança incompreendida: análise de um roteiro familiar

Caio Moretto Ribeiro

SÃO PAULO-SP 
CAIO MORETTO RIBEIRO

\title{
A criança incompreendida: análise de um roteiro familiar
}

\author{
Versão Original
}

Dissertação apresentada à Faculdade de Educação da Universidade de São Paulo para a obtenção do título de Mestre em Educação.

Área de concentração: Psicologia e Educação

Orientadora: Profa. Dra. Ana Laura Godinho Lima

SÃO PAULO-SP

2018 
AUTORIZO A REPRODUÇÃO E DIVULGAÇÃO TOTAL OU PARCIAL DESTE TRABALHO, POR QUALQUER MEIO CONVENCIONAL OU ELETRÔNICO, PARA FINS DE ESTUDO E PESQUISA, DESDE QUE CITADA A FONTE.

Catalogação na Publicação

Serviço de Biblioteca e Documentação

Faculdade de Educação da Universidade de São Paulo

37.046 Ribeiro, Caio Moretto

R484c A criança incompreendida: análise de um roteiro familiar / Caio Moretto Ribeiro; orientação Ana Laura Godinho Lima. São Paulo: s.n., 2018.

$161 \mathrm{p}$.

Dissertação (Mestrado - Programa de Pós-Graduação em Educação. Área de Concentração: Psicologia e Educação) - - Faculdade de Educação da Universidade de São Paulo.

1. Educação 2. Infância 3. Família 4. Cinema I. Lima, Ana Laura Godinho, orient.

Elaborada por Natalina de Jesus Delfina da Luz - CRB-8/4018 
RIBEIRO, C. M. A criança incompreendida: análise de um roteiro familiar. 2018. 160 p.

Dissertação (Mestrado em Educação) - Faculdade de Educação, Universidade de São Paulo, São Paulo, 2018.

Aprovado em:

Banca Examinadora

Profa. Dra.

Instituição:

Julgamento:

Profa. Dra.

Instituição:

Julgamento:

Profa. Dra.

Instituição:

Julgamento 


\section{SUMÁRIO}

AGRADECIMENTOS

$\begin{array}{ll}\text { RESUMO } & 7\end{array}$

$\begin{array}{lr}\text { ABSTRACT } & 8\end{array}$

INTRODUÇÃO E JUSTIFICATIVA 9

1. Considerações teóricas metodológicas: o cinema como discurso 17

2. Natureza incompreendida da criança, natureza compreensiva da mãe 26

2. 1. Incompreendido, de Florence Montgomery (1869) 26

2. 2. A construção discursiva da criança incompreendida em Misunderstood 29

2. 3. Quem pode ocupar a posição de compreensivo e quem não pode? 38

2. 4. Individualidade relativa da criança 49

3. Infância incompreendida, função materna reestruturante $\mathbf{5 2}$

3. 1. Quando o Amor é Cruel (Incompreso) 53

3. 2. Mary Poppins $\quad 60$

3. 3. A Noviça Rebelde 69

3. 4. O discurso sobre a infância em Quando o Amor é Cruel, Mary Poppins e A Noviça Rebelde 73

4. Essência individual incompreendida da criança, família que aceita 76

4.1. Billy Elliot $\quad 76$

4.2. Minha Vida em Cor-de-Rosa 88

4.3. A Família Bélier 101

4.4. Moana 108

4.5. O Grande Dia 117

4.6. Pequena Miss Sunshine 126

4.7. Incompreendida 139

4.8. Aceitar os filhos como eles são 149

CONSIDERAÇÕES FINAIS - TELEVISÃO 156

REFERÊNCIAS 


\section{AGRADECIMENTOS}

À Profa. Dra. Ana Laura Godinho Lima, minha orientadora, e a todos do grupo de estudos Psicologia, Pedagogia e Relações de Poder pelo incentivo, pelas correções e pela companhia intelectual nesses três anos.

Às professoras doutoras Carlota Boto e Valéria Cazetta, pela leitura atenta e pelas indicações durante a qualificação.

Aos amigos Thiago Aoki, Rita Barbosa, Fábio Accardo, Laís Braga, Fernando Mekaru, Hugo Ciavatta e André Lopes, que sempre me estimularam, pelo exemplo e pelas palavras, a continuar estudando e tentando entender melhor o mundo em que vivemos.

Aos alunos que enriqueceram esse trabalho com suas perguntas, sem saber que eram minhas também.

Ao meu avô Doly, que nos deixou no intervalo de tempo em que escrevia esse trabalho, pelo exemplo.

Aos meus pais Márcio e Filomena, pelo amor.

Aos meus irmão, Márcio e Bianca, pela amizade.

Ao Lucas, Thais, Zero, Cecília, pelo apoio.

Aos meus filhos Samuel e Isabel, que atravessaram nossas vidas nos transformando a todos e trazendo tanta inquietação e tantas alegrias.

À Mariana, pela companhia e pelo amor que se transforma e se renova, por insistir em sonhar comigo e por rir e recomeçar a cada vez que precisamos fazer novos planos. 
"Para os seres humanos, a necessidade de trabalhar conscientemente em suas relações recíprocas nunca tem fim. " (ELIAS, 2010) 


\section{RESUMO}

RIBEIRO, C. M. A criança incompreendida: análise de um roteiro familiar. 2018. 160 p. Dissertação (Mestrado em Educação) - Faculdade de Educação, Universidade de São Paulo, São Paulo, 2018.

Em 1869, livro mais vendido na Inglaterra, 12 mil exemplares em quatro anos, foi Misunderstood (Incompreendido), de Florence Montgomery. Em 1966, o livro foi transformado no filme Quando o amor é cruel, uma tradução bastante livre do título original: Incompreso, de Luigi Comencini. Em 2014, a diretora Asia Argento realizou uma releitura da obra em seu filme Incompresa (Incompreendida). Três momentos distintos, três crianças incompreendidas. Utilizando essas obras como eixo condutor e ampliando a análise com a decisão controlada de observá-los ao lado de outros filmes que tematizam as relações entre pais e filhos e a criança incompreendida pelos pais - Mary Poppins, A Noviça Rebelde, Billy Elliot, Minha Vida em Cor-de-rosa, A Família Bélier, Moana, O Grande Dia e Pequena Miss Sunshine - observamos: como se constrói o enunciado da criança como incompreendida em cada uma dessas produções, com quais outros enunciados se relaciona e de que maneira, qual é a forma de compreendê-las que se ensina aos adultos e que normas se constroem. Tomando os filmes e textos como discursos, utiliza-se do instrumental teórico desenvolvido por Michel Foucault para identificar um conjunto de normas produzidas discursivamente e dirigidas aos adultos sobre como compreender as crianças. Realiza-se, portanto, uma análise em três tempos sobre o governo à distância das crianças pelas normas produzidas por textos e filmes que têm como tema central a criança incompreendida, de modo a tornar pensáveis algumas relações entre família e educação.

Palavras-chave: Educação. Infância. Família. Cinema. 


\begin{abstract}
RIBEIRO, C. M. The misunderstood child: analysis of a familiar script. 2018. 160 p. Dissertação (Mestrado em Educação) - Faculdade de Educação, Universidade de São Paulo, São Paulo, 2018.

In 1869, Misunderstood, written by Florence Montgomery, was England's bestselling book: 12 thousand prints in four years. In 1966, the book was transformed into the movie Incompreso, by Luigi Comencini. In 2014, the director Asia Argento released her own version of Comencini's movie, called Incompresa. Three different moments, three misunderstood children. Following these works as a guideline and enlarging the analysis with the controlled decision to observe them next to other movies about parent-child relationships and children misunderstood by their parents - Mary Poppins, The Sounds of Silence, Billy Elliot, Ma Vie en Rose, Famille Bélier, Moana, Le Grand Jour and Little Miss Sunshine - , we observe: how the statement of the misunderstood child is made up in each production, to what other statements it relates and in which way, how do these works teach parents to understand their children and which standards they produce. Analysing the book and movies as discourse, we use Michel Foucault's theoretical tools to identify the discursive making of a set of standards directed to parents on how to understand their children. We analyse in three different moments, the governing at a distance of the children by the standards produced by works about misunderstood children, aiming to make it possible to think about some relations between family and education.
\end{abstract}

Keywords: Educação. Childhood. Family. Cinema. 


\title{
INTRODUÇÃO E JUSTIFICATIVA
}

A partir das discussões da Constituinte, registrou-se na Constituição de 1988, em seu artigo 226, que “A família, base da sociedade, tem especial proteção do Estado" e definiu-se no $\S 3^{\circ}$ que "Para efeito da proteção do Estado, é reconhecida a união estável entre o homem e a mulher como entidade familiar, devendo a lei facilitar sua conversão em casamento" e no $\S 4^{\circ}$ que "Entende-se, também, como entidade familiar a comunidade formada por qualquer dos pais e seus descendentes".

Da forma como foi escrito, o texto abriu margem para diferentes interpretações sobre aquilo que se entende legalmente como família no Brasil. Enquanto um grupo compreendia que a definição se restringia à união entre homem e mulher, outro argumentava que isso não estava discriminado no próprio texto. Assim, com o objetivo de eliminar a divergência das interpretações, em 5 de maio de 2011, o Supremo Tribunal Federal (STF) julgou a Ação Direta de Inconstitucionalidade (ADI) 4277 e determinou que:

\begin{abstract}
A Constituição de 1988, ao utilizar-se da expressão "família", não limita sua formação a casais heteroafetivos nem a formalidade cartorária, celebração civil ou liturgia religiosa. Família como instituição privada que, voluntariamente constituída entre pessoas adultas, mantém com o Estado e a sociedade civil uma necessária relação tricotômica. Núcleo familiar que é o principal lócus institucional de concreção dos direitos fundamentais que a própria Constituição designa por "intimidade e vida privada" (inciso $\mathrm{X}$ do art. $5^{\circ}$ ). Isonomia entre casais heteroafetivos e pares homoafetivos que somente ganha plenitude de sentido se desembocar no igual direito subjetivo à formação de uma autonomizada família. Família como figura central ou continente, de que tudo o mais é conteúdo. Imperiosidade da interpretação não-reducionista do conceito de família como instituição que também se forma por vias distintas do casamento civil. Avanço da Constituição Federal de 1988 no plano dos costumes. Caminhada na direção do pluralismo como categoria sócio-político-cultural. Competência do Supremo Tribunal Federal para manter, interpretativamente, o Texto Magno na posse do seu fundamental atributo da coerência, o que passa pela eliminação de preconceito quanto à orientação sexual das pessoas. (BRASIL, 2011)
\end{abstract}

A decisão do STF definiu o entendimento de que a união homoafetiva está em concordância com a definição de família da Constituição e deve, portanto, ser aceita legalmente, permitindo o casamento homoafetivo em cartório. A medida, por sua vez, provocou reação de setores da sociedade contrários à união homoafetiva, o que culminou com a articulação para a aprovação do Projeto de Lei 6583 de 2013, que instituiria o Estatuto da Família. Se aprovado, o projeto decretaria que: 
Para os fins desta Lei, define-se entidade familiar como o núcleo social formado a partir da união entre um homem e uma mulher, por meio de casamento ou união estável, ou ainda por comunidade formada por qualquer dos pais e seus descendentes. (BRASIL, 2013)

Esse texto restringiria o entendimento do STF e impediria o reconhecimento legal das uniões homoafetivas. O projeto ganhou força em 2015 quando o deputado Eduardo Cunha (PMDB) tornou-se presidente da Câmara dos Deputados e autorizou a criação de um Comissão Especial para acelerar a implantação do Estatuto da Família.

Em campanha para impedir a redefinição legal do termo família proposta pelos deputados da Frente Parlamentar Evangélica e seus aliados, a Associação Brasileira de Famílias Homoafetivas, a Coordenadoria Especial da Diversidade Sexual do Rio de Janeiro e a agência de publicidade NBS se juntaram ao Instituto Houaiss e realizaram uma campanha para a redefinição do verbete "família" no dicionário de modo a contemplar todas as famílias brasileiras. A principal ação da campanha foi a alteração do verbete família no dicionário Houaiss em maio de 2016. A definição de família como "Grupo de pessoas vivendo sob o mesmo teto (especialmente o pai, a mãe e os filhos) $[\ldots] "$ foi colocada como item 1.1 e a definição principal passou a ser "Núcleo social de pessoas unidas por laços afetivos, que geralmente compartilham o mesmo espaço e mantêm entre si uma relação solidária". (HOUAISS, 2016)

Esta não é primeira grande transformação do termo família registrada nos dicionários e provavelmente não será a última. No que pesem as diferenças entre cada país, podemos acompanhar, de acordo com o sociólogo francês estudioso das famílias, François de Singly, importantes transformações que foram registradas em 1680 e no século XIX.

\footnotetext{
Segundo as definições do termo "família" nos dicionários, a separação da família próxima do resto do parentesco e dos criados surge pela primeira vez em França no dicionário de Richelet de 1680. A equivalência entre a palavra família e o conteúdo "pai, mãe e filhos" só se torna evidente no século XIX. Em 1835, o Dictionnaire de l'Académie diz relativamente à "Família": "Diz-se por vezes de parentes que vivem juntos; e mais particularmente do pai, da mãe e dos filhos". (SINGLY, 2007, p. 99)
}

A primeira transformação descrita por Singly, diz respeito à nuclearização da família, que deixa de fazer referência ao conjunto completo do núcleo produtivo a ela associado, o que incluía escravos, afilhados e criados, entre outros, e passa a se restringir à "família próxima”. No século XIX, essa separação se radicaliza e o verbete passa a descrever a família a partir do triângulo "pai, mãe e filhos", excluindo os criados e a ascendência. 
O filósofo Michel Foucault descreve uma linha que colabora para a passagem da família relacional que vigora, de acordo com o autor, até meados do século XVIII, para a família-célula, que a substitui ao analisar as campanhas antimasturbatórias levadas a cabo pelo discurso médico desse período.

\begin{abstract}
A família aristocrática e burguesa (já que a campanha se limita precisamente a essas formas de família), até meados do século XVIII, era afinal essencialmente uma espécie de conjunto relacional, feixe de relações de ascendência, descendência, co-lateralidade, parentesco, primogenitura, aliança, que correspondiam a esquemas de transmissão de parentesco, de divisão e repartição dos bens e dos estatutos sociais. Era essencialmente às relações que se referiam efetivamente os interditos sexuais. $\mathrm{O}$ que está se constituindo é uma espécie de núcleo restrito, duro, substancial, maciço, corporal, afetivo da família: a família-célula no lugar da família relacional, a família-célula com seu espaço corporal, com seu espaço afetivo, seu espaço sexual, que é inteiramente saturado pelas relações diretas pais-filhos. Em outras palavras, não serei tentado a dizer que a sexualidade perseguida e proibida da criança e, de certa forma, a consequência da formação da família restrita, digamos conjugal ou parental, do século XIX. Direi, ao contrário, que ela é um dos seus elementos constituintes. Foi valorizando a sexualidade da criança, mais exatamente a atividade masturbatória da criança, foi valorizando o corpo da criança em perigo sexual que se deu aos pais a diretriz imperativa de reduzir o grande espaço polimorfo e perigoso da gente da casa e constituir com seus filhos, sua progenitura, uma espécie de corpo único, ligado pela preocupação com a sexualidade infantil, pela preocupação com o auto-erotismo infantil e com a masturbação: pais, cuidem de suas filhas excitadas e das ereções de seus filhos, e é assim que vocês se tornarão verdadeira e plenamente pais!
\end{abstract}

(FOUCAULT, 2001, p. 314-5)

A nuclearização da família tem uma história recente. Se seguimos os passos de Foucault, podemos dizer que a história da família-célula, conjugal, é também uma história da medicalização da família a partir do discurso antimasturbatório, que não tinha um caráter moral, mas eminentemente médico. A família tal qual estamos acostumados a admiti-la, sinônimo de "pai, mãe e filhos", é uma família atravessada por discurso de especialistas, uma família medicalizada.

Jurandir Freire Costa, em seu livro Ordem Médica, Norma Familiar (1989), descreve um processo similar ao analisar as transformações da família colonial brasileira, "grande corpo socioeconômico", para a família conjugal, célula da sociedade, que se forma após o período joanino e a vinda da corte portuguesa para o além-mar em 1808. O discurso médico se articula, de acordo com o autor, com um mudança na forma de governo dos cidadãos e reorganiza o poder no interior da família. Os escravos, "até então sinal de conforto, convertia-se em ameaça de doença". (COSTA, 1989, p. 124). A tática da medicina higiênica, 
como nos mostra o autor, era incompatível com a presença de escravos na família, que passa a ser combatida com o apoio da norma médica. Não mais autossuficiente, essa família, que passa a ter na mulher o ponto estratégico de contato com o discurso médico higienista, se reduz ao mesmo tempo em que se liga com a cidade.

\begin{abstract}
Vagarosamente e seguramente, a família, conduzida pela atenção benevolente do médico, fazia de seus laços e de sua casa aquele ambiente 'doce e encantador' tão solicitado pela higiene. Seu grande corpo latifundiário, patriarcal, teológico foi esfacelado. Inicialmente expulso da casa antiga para a cidade moderna; em seguida, recalcado e reintroduzido no novo lar íntimo, higienicamente reorganizado. No convívio interno, reduziu seus prolongamentos e aproximou seus membros, constituindo a família nuclear. No convívio externo aprendeu pelo medo a rearticular suas ligações com o mundo. Em vez de absorver, antropofagicamente, o ambiente social, desenvolveu um metabolismo seletivo, bem regulado, assimilando certos fatos, rejeitando outros, mantendo seu equilíbrio pelas leis de saúde. Aprendeu, igualmente, a depender da cidade, do todo social. A não mais considerar-se auto-suficiente, nem querer para si essa tarefa, quando podia utilizar a divisão social do trabalho. Seu contato com o mundo tornou-se mais orgânico, menos onipotente. A família converteu-se, de grande corpo socioeconômico, em célula da sociedade. (COSTA, 1989, p. 140-1)
\end{abstract}

As mudanças do verbete nos dicionários descritas por Singly apontam, portanto, para um processo mais amplo de constituição de uma família conjugal e relacional. A mudança registrada em 2016, no Brasil, no entanto, ainda que inserida em uma importante discussão sobre a ampliação da noção de cidadania e do reconhecimento jurídico de famílias homoafetivas, inclui um outro critério para determinação de família, até então ausente nas definições principais do verbete família dos dicionários: o afeto.

Tanto a família relacional descrita por Foucault, quanto a célula familiar descrita por Costa são famílias afetivas. Não se trata, portanto, de uma característica inédita nesse processo de transformação das famílias. No entanto, o registro dessa característica em um verbete de dicionário evidencia um aspecto desse processo e dessa disputa narrativa: a definição não se baseia mais em uma estrutura e sim na norma. Não é a relação de parentesco entre os membros que define o que é uma família, mas a forma como se relacionam.

O sociólogo francês François de Singly escreve que

Não é possível, para analisar as famílias de hoje, partir de dados estatísticos, designar as diferenças de composição a partir de um eixo tradição/modernidade. As famílias recompostas, por exemplo, não são mais modernas do que as famílias em que as crianças vivem com os pais. Na maioria dos casos, as primeiras derivam das 
segundas, e não mudam de natureza histórica ou sociológica por artes mágicas do divórcio. (SINGLY, 2007, p. 30)

Se, como escreve Norbert Elias, "qualquer relacionamento familiar é um processo" (ELIAS, 2010), como analisar as famílias em transformação sem lhes impor modelos que distorçam sua percepção? Esta é a contribuição que, cremos, uma análise do discurso cinematográfico pode dar. Iniciar a análise da família pelo cinema permite, portanto, que se crie um jogo de novas dicotomias que permita pensar as famílias por outras categorias que não aquelas já consagradas pela sociologia da família. O sociólogo François de Singly aponta um caminho interessante ao notar que "independentemente da sua forma, as famílias estão sujeitas às mesmas normas, às mesmas tensões" (SINGLY, 2007, p. 30). O cinema permite pensar essas tensões.

O cinema contribui para pensar os problemas contemporâneos, inclusive a família: o modo como são formulados e o modo como são enfrentados. Como defende Douglas Kellner (KELLNER, 2001), a mídia tem hoje papel central na construção das identidades, no processo de socialização e mesmo na elaboração de projetos de vida. O cinema também produz sonhos, ensina os meios legítimos de buscá-los e como lidar com os desvios. A construção da subjetividade nas sociedades liberais cosmopolitas contemporâneas também passa pelo cinema. O cinema é uma “pedagogia cultural” (STEINBERG, 2004).

O que os discursos cinematográficos contemporâneos sobre família mobilizam como problemas? De que formas esses problemas são solucionados? Em outras palavras: de que forma alguns problemas são tomados pelo cinema como um problema de família e como eles ensinam a resolvê-los? Que relações familiares incentivam? Como participam desse processo de construção da subjetividade das pessoas em relação ao modo de viver em família? O caráter pedagógico que buscamos, portanto, não se dá pelo recorte do objeto, uma vez que não analisamos filmes sobre escola nem pensando em seu uso didático, mas pela própria relação do cinema com as pessoas enquanto elemento de um processo de subjetivação, que ensina e que tenta governar condutas.

Se o cinema tem, como defende Bergala, a vocação da alteridade, de "nos fazer compartilhar experiências que, sem ele, nos permaneceriam estranhas" (BERGALA, 2008, p. 38 ), poderíamos, abusando um pouco da ambiguidade da palavra, dizer que o cinema tem a 
vocação de tornar familiar e perguntar: quais modos de se relacionar, quais discursos sobre a relação entre pais e filhos o cinema tem tornado familiares?

Os filmes produzem narrativas acerca de quem somos como membros de uma família - o que é uma família, o que é ser um filho, o que é ser mãe ou pai, o que caracteriza os vínculos entre pais e filhos, que tipos de responsabilidades têm as famílias em relação aos seus filhos, que tipos de obrigações têm os filhos em relação aos seus pais; de que modo esses vínculos e obrigações podem gerar tensões entre, por um lado, as expectativas das famílias em relação às crianças e, por outro lado, os anseios das próprias crianças em viver a própria vida, em tornar-se independentes dos pais etc. Em última análise, portanto, é possível dizer que essa tensão diz respeito à liberdade do indivíduo em face das determinações sociais, a tensão do indivíduo vivendo em sociedade. A questão que se coloca é "até que ponto se pode desafiar a ordem social para viver uma vida livre?" Por isso trata-se de uma questão importante, essencial mesmo na modernidade.

Para empreender a análise dos filmes enquanto parte de um dispositivo que nos subjetiva, tomamos os filmes enquanto discursos. Isso significa dizer que consideramos que as narrativas fílmicas são acontecimentos efetivamente produzidos (e não meras representações), levamos em conta um efeito de raridade e as consideramos como um domínio autônomo, porém não isolado. (FOUCAULT, 2014, p. 145-149). Esses aspectos considerados simultaneamente nos levam a considerar os filmes sobre a família como parte de uma formação discursiva mais ampla - o discurso sobre a família moderna, se se quiser cuja função "pedagógica” é ensinar aos espectadores o que é uma família moderna, qual a sua função, como são/devem ser vividos os papéis de pai, mãe, filho, irmão nessa configuração. Essas histórias não criam do início uma concepção de família, mas se relacionam com outros discursos que descrevem a família e/ou a ela se dirigem para defendê-la, curá-la, celebrá-la ou promover a sua normalização: discursos científicos da psicologia, da puericultura, da pedagogia; discursos moralizantes, religiosos ou não; discursos literários, didáticos, jurídicos ou outros.

Em nossa análise, estabelecemos como eixo central o enunciado de que a criança é incompreendida. Exploramos a construção discursiva desse enunciado em três momentos distintos ou em três séries discursivas distintas. 
No primeiro capítulo, analisamos a construção do enunciado de que a criança é incompreendida pelos pais no livro Misunderstood, de Florence Montgomery, escrito em 1869 e traduzido para o português na década de 1960 como Incompreendido (1960). Observamos como se constrói discursivamente a incompreensão da personagem, quem a enuncia, com quais outros enunciados se articula, como é solucionada e quem pode, na narrativa, desempenhar o papel de compreensivo.

No segundo capítulo analisamos o filme italiano Quando o Amor é Cruel (1966), de Luigi Comencini, uma adaptação para as telas do romance de Florence Montgomery. Observamos a nova dinâmica dos enunciados no filme e expandimos a análise colocando-o lado a lado com outros dois filmes sobre relações entre pais e filhos produzidos na mesma década: Mary Poppins, de Robert Stevenson (1964) e A Noviça Rebelde, de Robert Wise (1965).

No terceiro passamos aos filmes contemporâneos. Analisamos o filme Incompreendida, de Asia Argento (2014), inspirado livremente em Quando o Amor é Cruel, mas, antes, observamos os filmes: Billy Elliot, de Stephen Daldry (2001); Minha Vida em Cor-de-Rosa, de Alain Berliner (1997); A Família Bélier, de Eric Lartigau (2014); Moana: um mar de aventuras, de John Musker e Ron Clements (2016); O Grande Dia, de Pascal Plisson (2015); e Pequena Miss Sunshine, de Jonathan Dayton (2006).

O eixo condutor, portanto, é o livro Misunderstood (1869) e sua reverberação em Quando o Amor é Cruel (1960) e Incompreendida (2014). Esses filmes que apresentam o enunciado de que a criança é incompreendida já no próprio título foram analisados ao lado de outros que tratam da relação entre pais e filhos e nos quais, a única exceção sendo $O$ Grande Dia (2015), o tema da criança incompreendida se apresenta em destaque.

Os filmes contemporâneos foram escolhidos por um critério de diversidade: de temas (surdez, sexualidade, balé, aventura no mar, concurso de beleza etc), de gêneros (filmes classificados como ficção, documentário ou animação) e de nacionalidade (não restringindo a análise a filmes apenas norte-americanos apenas). Todos os filmes, no entanto, são filmes de ampla bilheteria, distribuídos internacionalmente em cinemas comerciais e que passaram no 
Brasil. Como o interesse é analisar a norma, não ampliamos a análise para filmes raros ou direcionados a algum público muito específico.

O título desta dissertação já revela que há uma continuidade em relação ao enunciado de que a criança é incompreendida pelos pais. A estrutura dos capítulos, tomando como eixo condutor o enunciado "a criança é incompreendida pelos pais", mas analisando a forma como este se articula a outros em cada momento, pretende evidenciar algumas rupturas, de modo a explicitar algumas especificidades do discurso cinematográfico contemporâneo sobre a família. 


\section{Considerações teóricas metodológicas: o cinema como discurso}

Este trabalho se insere em uma discussão sobre educação ao menos de duas formas distintas: primeiro, pelo tema da infância e da análise específica do enunciado da criança incompreendida; segundo, e aqui marca-se a especificidade que distingue este estudo de outros do campo educacional, pela forma como articula educação e cinema, tomando os filmes como práticas discursivas, como acontecimentos, enunciados efetivamente pronunciados e que participam de um processo de subjetivação, que ensinam modos de viver em família. Inspirados, portanto, em uma análise de discurso foucaultiana, tal qual proposta em A Arqueologia do Saber (2014), suspendemos algumas unidades tradicionais do discurso - tradição, influência, evolução, mentalidade, espírito do tempo, livro, obra - para fazer aparecer outras relações possíveis que não remetem diretamente a um sujeito fundador ou à distância entre as representações e aquilo que se representa.

Rosa Maria Bueno Fischer, em seus estudos foucaultianos sobre mídia e juventude, coloca a questão nos seguintes termos: "Poderia afirmar-se que alguns sujeitos operam sobre as coisas e as inscrevem, transcrevem e transformam em palavras? Ou estas é que nos impulsionam a ver e tratar as coisas deste ou daquele jeito?” (FISCHER, 2014, p. 24) Essas perguntas são ilustrativas de dois modos de análise sobre o cinema. A primeira é recorrente em alguns estudos que se valem do autor como unidade de síntese e que propõem estudos da filmografia ou de uma noção na filmografia de determinado diretor. A segunda, em análises que utilizam o cinema para decifrar a realidade não-fílmica, como vemos por exemplo, na análise de Amaury Cesar Moraes sobre a escola no cinema. Os filmes, para o autor, seriam vias de acesso para se identificar aquilo que chama de "imaginário social da época", uma vez que, de acordo com ele, "o filme é produzido segundo referências do imaginário social sobre a escola" e, portanto, "do mesmo modo que o desenvolvimento desses instrumentos [de análise fílmica] permite uma maior aproximação da verdade, os vários filmes também permitem, senão o conhecimento da "verdade educacional", ao menos da verdade acerca do imaginário sobre a escola”. (SETTON, 2004, p. 53) Amaury Cesar Moraes e Maria da Graça Jacintho Setton iniciam suas análises a partir de hipóteses similares, enunciada pela professora da seguinte forma: "Parte-se da hipótese de que os produtos da mídia são registros 
históricos de uma época, e, portanto, passíveis de serem vistos como reveladores de valores e significados culturais, e nesse sentido, essencialmente educativos". (SETTON, 2004)

Enquanto esse modo de análise privilegia o estudo de grandes características da mentalidade da época para explicar o cinema ou talvez, de maneira inversa, busca no cinema características reveladoras sobre a mentalidade geral de um tempo, o que pretendemos é uma análise que não tome o cinema como representação, mas como prática discursiva. Assim, evitamos supor a anterioridade de uma família empiricamente observável supostamente mais real em relação a outra construída pelo cinema, do mesmo modo como evitamos uma análise que busque nas famílias empiricamente observáveis reflexos de ideologias veiculadas pelo cinema. Como tomar a sociedade como ponto de explicação para o discurso cinematográfico se ela também é uma construção? Como escreve Paul Veyne: “A sociedade, longe de ser o princípio ou o termo de toda explicação, precisa ela própria ser explicada; longe de ser última, ela é o que dela fazem, a cada época todos os discursos e dispositivos de que ela é receptáculo.” (VEYNE, 2011, p. 44)

O mesmo poderíamos afirmar sobre a família, como o fez Norbert Elias ao escrever que:

As relações familiares são muitas vezes apresentadas como o fundamento de todas as relações sociais do ser humano. Mas isso é um equívoco. A estrutura familiar, quer dizer, o modo socialmente estabelecido de relação entre o homem, a mulher e a criança se desenvolvem em correlação com - e corresponde a - a sociedade mais ampla da qual ela faz parte. (ELIAS, 2010)

Nem a família como ponto de partida, nem a sociedade, mas também não o sujeito. Consideramos que o sujeito também é constituído historicamente, de modo que remontar uma rede de causalidades à função sintetizante de um sujeito transcendental ou de uma subjetividade psicológica seria ignorar as especificidades dessa transformação.

O discurso, assim concebido, não é a manifestação, majestosamente desenvolvida, de um sujeito que pensa, que conhece, e que o diz: é, ao contrário, um conjunto em que podem ser determinadas a dispersão do sujeito e sua descontinuidade em relação a si mesmo. É um espaço de exterioridade em que se desenvolve uma rede de lugares distintos. Ainda há pouco mostramos que não eram nem pelas "palavras" nem pelas "coisas" que era preciso definir o regime dos objetos característicos de uma formação discursiva; da mesma forma, é preciso reconhecer, agora, que não é nem pelo recurso a um sujeito transcendental nem pelo recurso a uma subjetividade psicológica que se deve definir o regime de suas enunciações. (FOUCAULT, 2014, p. 65) 
Se tanto sociedade (e família) como sujeito são construções que se modificam, antes de tomá-los como ponto de partida para uma análise histórica, buscamos uma outra forma de história que permita evidenciar tanto a transformação das práticas institucionais quanto a própria transformação dos sujeitos, os processos de subjetivação que nos constituíram, e não cessam de fazê-lo. Interessa-nos, portanto, menos a análise das influências da biografia individual de um diretor e sua suposta genialidade ou de algo como um suposto espírito da época em determinado discurso e mais a descrição das regularidades e das descontinuidades de uma série de enunciados efetivamente pronunciados. Aproximamo-nos mais, portanto, de uma perspectiva foucaultiana e dos Estudos Culturais, que aceita uma circularidade do discurso. Em outras palavras, aceitamos a possibilidade de que não seja o autor que determine totalmente as regras do discurso, mas que a dinâmica do próprio discurso delimite também aquilo que o autor pode falar. Portanto, estrategicamente, consideramos interessante, como sugere Foucault, partir da análise do discurso, perspectiva de análise que é sintetizada pela professora Rosa Maria Bueno Fischer ao escrever: "Nem espírito de época, nem as influências: antes, a descrição das transformações” (FISCHER, 2012, p. 22).

Nosso ponto de partida, portanto, é outro. Partimos da hipótese foucaultiana de que "tudo age sobre tudo, tudo reage contra tudo" (VEYNE, 2011, p. 98). Inclusive o discurso em sua dinâmica própria. Assim, deslocamos as perguntas sobre a origem e o grau das influências para outras como "o que se fala quando se fala em um filme ou livro sobre relações entre pais e filhos?”, “o que foi efetivamente dito sobre essa relação?", "há transformações no modo de falar sobre a relação entre pais e filhos?”, “o que os filmes ensinam sobre a forma de viver em família?”. Desta forma, o discurso cinematográfico não é analisado como revelador do espírito de um tempo ou de aspectos estruturais da sociedade, mas apenas descrito ao lado de outros discursos, de forma a tornar mais complexa nossa compreensão de nós mesmos, dos modos como são construídas nossas subjetividades e nossas relações, tornando pensáveis e transformáveis, se possível, aspectos que nos pareciam naturais.

Ao tomar os filmes e livros que compõem nosso arquivo como acontecimentos discursivos, apoiamo-nos em quatro princípios de análise descritos por Foucault em sua inaugural no Collège de France (FOUCAULT, 2015a). De modo a evitar esse jogo de 
significações prévias e buscar uma análise que não tome como ponto de partida nem a sociedade, a família, uma suposta natureza da infância anterior a qualquer discurso, uma subjetividade psicológica ou um sujeito transcendental, nos referimos ao princípio de especificidade:

não transformar o discurso em um jogo de significações prévias; não imaginar que o mundo nos apresenta uma face legível que teríamos de decifrar apenas; ele não é cúmplice de nosso conhecimento; não há providência pré-discursiva que o disponha a nosso favor. Deve-se conceber o discurso como uma violência que fazemos às coisas, como uma prática que lhes impomos em todo o caso; e é nesta prática que os acontecimentos do discurso encontram o princípio de sua regularidade. (FOUCAULT, 2015a, p. 100-101)

Tomar os filmes e livros como acontecimentos discursivos efetivos é admitir a hipótese da "total impossibilidade de uma imagem efetivamente representar algo" (MARCELLO; FISCHER, 2011, p. 505), de que não há nenhuma verdade oculta para além do filme que pudesse ser descoberta por uma análise psicológica da trajetória do realizador ou pela análise sociológica do "espírito da época" e, portanto, abrir mão das causalidades psicológicas ou sociais, em prol de uma descrição de acontecimentos discursivos. Além de não remeter a um jogo de significações prévias, mantemos a análise no nível da superfície do discurso, daquilo que foi efetivamente pronunciado, suas relações e regularidades. Trata-se do princípio de exterioridade:

não passar do discurso para o seu núcleo interior e escondido, para o âmago de um pensamento ou de uma significação que se manifestariam nele; mas, a partir do próprio discurso, de sua aparição e de sua regularidade, passar às suas condições externas de possibilidade, àquilo que dá lugar à série aleatória desses acontecimentos e fixa suas fronteiras. (FOUCAULT, 2015a, p. 101)

\section{Como escrevem Fabiana de Amorim Marcello e Rosa Maria Bueno Fischer:}

Somos hoje assolados por perguntas como: de que modo a criança é influenciada pela mídia? Qual o papel da mídia (ou do cinema, em particular) na produção de uma infância cada vez mais sexualizada, ou de uma juventude cada vez mais agressiva, agitada, violenta? Longe de tentarmos responder a estes questionamentos, nossa proposta é que voltemos nosso olhar a outras indagações, a nosso ver, anteriores: de que criança estamos falando, quando tratamos, em nossas pesquisas, da relação entre infância e cinema (infância e mídia)? Qual o conceito que temos de juventude, quando deixamos as questões de uma suposta influência tomarem a frente na arena das discussões? Temos clareza sobre estes aspectos? A ideia, portanto, é ir na direção contrária de uma generalização de categorias ou conceitos tão complexos como a infância, a juventude, a violência (e outros colocados em 
semelhante lógica). E isso a partir de dois movimentos: o primeiro, distante de toda e qualquer universalização; e outro, distante também da noção de influência porque isso implicaria entender a imagem em um mero aspecto mimético, vertical e linear. (MARCELLO; FISCHER, 2011)

Poderíamos transpor o discurso à pesquisa sobre relações familiares. Em vez de observar a influência dos filmes nas famílias, nos interessa pensar de que família se fala nos filmes, quais conceitos mobilizam, como essas relações familiares se articulam com a narrativa, quais enunciados são pronunciados sobre a criança, quem os pronuncia, com quais outros enunciados se articulam, de que forma? Não buscamos, portanto, a distância entre as famílias empiricamente observáveis e sua suposta representação para analisar quais classes, modos, estruturas são subrepresentadas etc. Não se pretende olhar "a mensagem cinematográfica como fonte de mensagens ideológicas de conservação e/ou resistência" (SETTON, 2004, p.83). O que pretendemos, a partir do princípio de exterioridade, é aceitar essa provocação de Marcello e Fischer (2011). Nem mensagem oculta, nem espírito do tempo, mas, como escreve Foucault: "Tento, ao contrário, definir relações que estão na superfície dos discursos; tento tornar visível o que só é invisível por estar muito na superfície das coisas" (FOUCAULT, 2014). Buscamos, a partir desse jogo de contrastes que é a análise histórica feita sempre a partir do presente, com os olhos do presente, fazer aparecer relações que estão na superfície, tão evidentes que nos passam despercebidas. Trata-se de olhar para o discurso não em sua profundidade ou em um significado oculto, mas em suas conexões. Como escreve Nikolas Rose, valendo-se de Deleuze e Guattari:

Em outras palavras, não se trata de questão sobre o que uma palavra, uma frase, uma estória ou um livro "quer dizer" ou o que ele "significa", mas, de forma distinta, de "com o que ele funciona, em conexão com que outras multiplicidades, as suas próprias são inseridas e metamorfoseadas" - não a sua profundidade ou peso semântico não revelado, mas suas conexões, associações e atividades "superficiais" (ROSE, 2011, p. 247)

Exploramos, do começo ao fim deste trabalho, a possibilidade e o potencial investigativo de uma análise de superfície. Em outras palavras, como escreve Foucault, quer-se "renunciar às 'coisas"”:

substituir o tesouro enigmático das "coisas" anteriores ao discurso pela formação regular dos objetos que só nele se delineiam; definir esses objetos sem referência ao fundo das coisas, mas relacionando-os ao conjunto de regras que permitem formá-los como objetos de um discurso e que constituem, assim, suas condições de possibilidade. (FOUCAULT, 2014, p. 58) 
Analisamos, aqui, portanto, a criança incompreendida não como algo preexistente a qualquer discurso que se trataria de revelar. Não como um objeto dado, mas como um objeto discursivamente construído. Como é construída discursivamente a criança incompreendida em cada série discursiva analisada? Quem pode enunciá-la enquanto incompreendida? De que forma? Articulando quais enunciados? Quais são as continuidades e rupturas nessa construção? Quais são suas condições de possibilidade?

Para poder produzir um discurso fílmico sobre família o diretor ou diretora precisa ocupar uma posição de sujeito específica e reproduzir estruturas discursivas específicas, precisa se inserir em uma determinada ordem do discurso (FOUCAULT, 1996). É por conta desse jogo entre o poder produtivo do discurso, as regras próprias que alguém precisa obedecer para falar algo legítimo e as posições específicas que alguém tem que ocupar para poder dizê-lo, que acreditamos ser interessante pensar a partir de uma centralidade do discurso, da compreensão de suas regularidades, de seus princípios de rarefação etc. Como diz Marisa Vorraber Costa: "Também estariam enganados aqueles que vislumbrassem uma vocação conspiratória nas agendas do currículo da televisão, consubstanciada em ensinamentos camuflados e intencionalidades subjacentes." (COSTA, 2002)

As corporações cinematográficas são certamente perigosas, como demonstra Steinberg (2004) ao analisar oligopólio da indústria midiática e da produção de bens culturais direcionados a crianças, mas isso não significa que a observação de suas estruturas seja suficiente para determinar as nuances dos discursos cinematográficos que produzem e de seus efeitos. Do mesmo modo, poderíamos dizer que, assim como a análise da lógica comercial da indústria, o estudo das características biográficas dos cineastas também não bastaria, uma vez que para poderem falar algo desse lugar, com apoio dessas corporações, precisam se inserir em uma ordem discursiva bastante precisa. A mesma autora conclui, a partir de Foucault: "as relações de poder são imanentes às pedagogias e seus discursos" (COSTA, 2002). Isso porque o discurso é uma prática, que "forma sistematicamente os objetos de que fala" (FOUCAULT, 2014, p. 60). O discurso é, como vimos no princípio de especificidade, uma violência, uma prática que impomos às coisas, de modo que nossa forma de agir em sociedade, em família e mesmo em relação a nós mesmos é marcada por práticas discursivas. E essas práticas discursivas têm uma autonomia relativa, uma espessura e uma dinâmica 
próprias. Se a raridade dos discursos pode ser associada à lógica mercadológica de sua produção, ela também pode ser explicada a partir da dinâmica do próprio discurso. Trata-se do princípio de inversão: "lá onde cremos reconhecer a fonte dos discursos, o princípio de sua expansão e de sua continuidade, nessas figuras que parecem desempenhar um papel positivo como a do autor, da disciplina, da vontade de verdade, é preciso reconhecer, ao contrário, o jogo negativo de um recorte e de uma rarefação do discurso." (FOUCAULT, 2015a, p. 100).

Os discursos são raros, mas isso não significa que exista por trás deles um discurso mais profundo e ininterrupto que caberia a nós restituir: princípio de descontinuidade. Como escreve Foucault:

\begin{abstract}
o fato de haver sistemas de rarefação não quer dizer que por baixo deles e para além deles reine um grande discurso ilimitado, contínuo e silencioso que seja por eles reprimido e recalcado e que nós tenhamos por missão descobrir, restituindo-lhe, enfim, a palavra. Não se deve imaginar, percorrendo o mundo e entrelaçando-se em todas as suas formas e acontecimentos, um não dito ou um impensado que se deveria, enfim, articular ou pensar. Os discursos devem ser tratados como práticas descontínuas, que se cruzam por vezes, mas também se ignoram ou se excluem. (FOUCAULT, 2015a, p.100)
\end{abstract}

Porntanto, em lugar dos princípios de criação, das análises de influência ou determinação, da busca por significações ocultas ou de uma suposta unidade do discurso, analisamos o discurso como séries de acontecimentos raros e buscamos identificar suas condições de possibilidade, suas regularidades e suas descontinuidades. Partir do discurso para fazer aparecer algumas relações que nos constroem como somos, que nos fazem pensar e viver em família do jeito que vivemos, evidenciar algumas características do nosso modo de subjetivação presente, eis a proposta. Se essa pesquisa também só é possível enquanto prática discursiva, que ela possa operar não como um comentário que contribua para a rarefação dos discursos, mas como uma sugestão que convide a pensar de outro modo que, evidenciando algumas regularidades e descontinuidades na trajetória do enunciado da criança incompreendida e dos enunciados com os quais se articula, permita que novos acontecimentos discursivos sejam possíveis.

\title{
A análise de um enunciado
}


Na presente análise, o estudo dos acontecimentos discursivos é centrado no enunciado "a criança é incompreendida pelos pais". O conceito de enunciado, central na modalidade de análise do discurso delineada por Foucault, está longe de ser simples ou auto-evidente. Em $A$ Arqueologia do Saber, acompanhamos o filósofo no processo de delimitação do que entende por enunciado, e encontramos ao longo do livro, algumas definições distintas. Antes de defini-lo, Foucault nos alerta que não se trata, como se poderia supor, de uma unidade: ele [o enunciado] não é em si mesmo uma unidade, mas sim uma função que cruza um domínio de estruturas e de unidades possíveis e que faz com que apareçam, com conteúdos concretos, no tempo e no espaço. (FOUCAULT, 2014, p. 105)

Não sendo uma estrutura, nem tendo uma unidade material a priori, não é possível analisá-lo "nem por uma análise formal, nem por uma investigação semântica, nem por verificação". Não se trata se encontrar o significado oculto ou primeiro ou mais verdadeiro, nem de remontar a uma estrutura que permita tudo ser dito. $\mathrm{O}$ enunciado sendo uma função que atravessa a linguagem e, ao atravessá-la permite a aparição de unidades concretas, é apenas observável na relação entre aquilo que foi efetivamente pronunciado, "pela análise das relações entre o enunciado e os espaços de diferenciação, em que ele mesmo faz aparecer as diferenças". (FOUCAULT, 2014, p. 111) Em vez de um "referente", Foucault relaciona o enunciado a um princípio de diferenciação, uma vez que aquilo a que o enunciado se refere não existia previamente. É no próprio ato de enunciação que se recorta aquilo que é diferenciado do todo e que identificamos como referente. $\mathrm{O}$ enunciado também se relaciona a uma posição de sujeito, a um campo associado e a uma materialidade específica.

Sobre o enunciado "a criança é incompreendida pelos pais", poderíamos, portanto, dizer: a criança incompreendida : não é anterior ao conjunto de enunciados que a descrevem e a definem. É o próprio acontecimento da prática discursiva que produz a criança incompreendida e isola esse enunciado de outros possíveis. A posição de sujeito seria o status específico que alguém precisaria ter, o lugar que uma pessoa precisaria ocupar para poder pronunciar esse enunciado. Quem é capaz de afirmar que a criança é incompreendida? A incompreensão da criança pode ser construída em relação ao enunciado segundo o qual o adulto, por não compreendê-la, pensa que ela não tem coração, em relação ao enunciado de uma suposta essência não admitida pelos adultos ou em relação a outros enunciados. É apenas nessa relação com o campo associado que é possível afirmar o sentido de um enunciado. Para Foucault, um atributo fundamental do enunciado é a sua dimensão material, 
de modo que pensamentos não expressos, intenções ocultas não se configuram como enunciados. Um enunciado pode ter como superfície de emergência um romance literário ou um tratado médico, um filme, uma legenda. Ele chega a nós porque está inscrito em alguma materialidade.

No caso específico, analisamos, portanto, o enunciado da criança incompreendida e não a frase "a criança não é compreendida pelos pais". Que essa construção específica não apareça literalmente dessa forma exata em nenhum momento, nada muda, desde que, pela observação dos exemplos extraídos da base empírica selecionada seja possível depreendê-lo como uma função que está ali presente. 


\section{Natureza incompreendida da criança, natureza compreensiva da mãe}

Em 1869, o livro mais vendido na Inglaterra, 12 mil exemplares em quatro anos, foi Misunderstood (Incompreendido), de Florence Montgomery (ALTICK, 1986). Em 1966, o livro foi transformado no filme Quando o amor é cruel, uma tradução bastante livre do título original: Incompreso, de Luigi Comencini. Em 2014, a diretora Asia Argento realizou uma releitura da obra em seu filme Incompresa (Incompreendida). Três momentos distintos, três crianças incompreendidas. Como se constrói o enunciado da criança como incompreendida em cada uma dessas produções? A análise desses discursos permite tornar pensável um conjunto de relações produzidas discursivamente sobre o governo à distância das crianças pela condução das condutas dos adultos que delas se ocupam.

Em primeiro momento, olhamos para o enunciado de que a criança é incompreendida, tal qual produzido discursivamente no livro de Florence Montgomery no século XIX, na Inglaterra vitoriana e seu campo de coexistência com outros enunciados. Depois, observamos quem pode legitimamente compreender a criança e de quem não pode no texto. Ainda, ao final deste capítulo, observamos alguns efeitos produzidos em relação à individualidade de cada membro da família.

\section{1. Incompreendido, de Florence Montgomery (1869)}

Em nossa análise, foram utilizadas, lado a lado, a edição brasileira Incompreendido, de 1960, única que foi encontrada em português, e a primeira versão do texto inglês, Misunderstood, de 1869, disponível em formato digital, de forma a evitar problemas que poderiam ser causados pela análise exclusiva de uma tradução tardia.

Em Incompreendido, escrito por Florence Montgomery em 1869, a narrativa começa dois anos depois da morte de Lady Adelaide Duncombe, com a criada Virgine tentando disciplinar o primogênito Humphrey (7 anos) e o caçula Miles (4 anos), enquanto o pai, Sir Everard Duncombe, membro do Parlamento inglês, realizava, fora de casa, suas funções 
públicas, voltando para casa apenas em visitas rápidas e aos finais de semana. O livro descreve as artimanhas dos garotos para se livrar da vigilância da governanta francesa e a angústia do pai em tentar proteger o mais novo e compreender o mais velho, que acreditava "não ter coração" até o final. A situação muda apenas após um acidente, quando Humphrey fica sob cuidados médicos e o pai se aproxima, pouco antes da morte do filho. A cada visita do pai, a governanta conta-lhe das traquinadas de Humphrey e de como ele expõe a saúde frágil de Miles a diversos riscos. Apesar de temer a morte do caçula, é o mais velho que é apresentado como incompreendido e que, após desobedecer o pai e escalar uma árvore podre sobre o lago, se acidenta, fica sem os movimentos e morre.

O livro contrapõe uma construção discursiva que busca apresentar uma suposta visão de mundo dos filhos àquilo que seria a visão dos pais e se pretende um livro direcionado a adultos para ensiná-los a compreender as crianças, como revela o prefácio da edição inglesa:

The following is not a child's story. It is intended for those who are interested in children; for those who are willing to stoop to view life as it appears to a child, and to enter for half-an-hour into the manifold small interests, hopes, joys, and trials which make up its sum.

It has been thought that the lives of children, as known by themselves from their own little point of view, are not always sufficiently realised, that they are sometimes overlooked or misunderstood ; and to throw some light, however faint, upon the subject, is one of the objects of this little story.

So much of it has been gathered from observation and recollection, that the Author cannot help hoping it may not entirely fail of its aim. (MONTGOMERY, 1869)

Lynne Rosenthal, doutora pela Columbia University, em seu artigo Misunderstood: A Victorian Children's Book for Adults (ROSENTHAL, 1974), comenta que, ao contrário dos livros para e sobre crianças produzidos na Inglaterra vitoriana, Misunderstood se diferencia por ser o primeiro a descrever o comportamento das crianças sem tentar modificá-lo, focando seus esforços na tentativa de transformar o comportamento dos pais e não o dos filhos. A autora encontrou, em uma edição de janeiro de 1870 do jornal The Saturday Review, um comentário sobre o livro em que um leitor afirmava que "Child-life itself does not sufficiently appeal to passion and sensation to claim strong interest from our hurried intelligence, yet its problems can not be neglected". A atenção sobre questões específicas da infância, apesar de já terem suscitado o interesse de alguns filósofos, ainda não eram um problema central para os pais, de tal forma que a proposta do livro é vista como inovadora, como dotada de um 
realismo raro. O mesmo leitor escreve: "We were not prepared for so faithful and suggestive a picture of childish life as... Misunderstood." (ROSENTHAL, 1974, p. 96) Trata-se, portanto, de um livro considerado inovador, que apresenta uma perspectiva nova sobre a infância à época ao apresentar com pretensões educativas e de governo, de modo que, ensinando adultos algo verdadeiro sobre as crianças, ajudasse a acabar com mal-entendidos.

O livro Incompreendido começa com a descrição dos irmãos Humphrey e Miles esperando pela chegada do pai na nursery. Na versão brasileira, a tradução apresenta aos leitores, em nota, uma definição de nursery da seguinte maneira:

No mundo anglo-saxão, a nursery é o apartamento das crianças em geral, às vezes composto de uma só repartição, onde elas comem, dormem e brincam, sob a vigilância de uma moça ou de uma preceptora. (MONTGOMERY, 1960, p. 7)

De acordo com Rosenthal, a nursery era um padrão nas casas urbanas de famílias burguesas da época. Os pais, afirma, se separavam fisicamente dos filhos e tanto a mãe como o pai viviam vidas sociais próprias, ainda que de formas distintas, deixando as crianças ao encargo de criados, que se ocupavam delas no andar superior. Pais e filhos, mesmo nos casos em que os pais não se ausentavam durante toda a semana, como o de Sir Everard, quase não se viam. Uma das consequências é que conheciam seus filhos por raros e rápidos momentos de convívio ou em segunda mão, pela informação passada pelos criados. (ROSENTHAL, 1974, p. 96)

A historiadora Catherine Hall (2009) chama a atenção para o fato de que esse modelo de construção, com uma clara separação dos espaços, era algo novo.

Uma casa desse tipo obedecia uma nova concepção. Não se conseguiria chegar a uma tal diferenciação do espaço nas ruas em forma de crescente das cidades setecentistas, ou talvez essa necessidade não se tivesse feito sentir. Os quartos separados para os filhos, a demarcação entre o local em que se cozinhava e o local em que se comia, tudo isso era novo, associado à ideia de um espaço diferente onde os homens trabalhavam. (HALL, 2009, p. 62)

Hall, porém, mostra que a vida social da mulher burguesa não era tão independente das crianças quanto poderia parecer na leitura de Rosenthal.

Nos meados do século XIX, na imaginação inglesa, a casa era o local das doçuras e delícias, mas percebida de forma diferentes pelos homens e pelas mulheres. Os homens podiam mesclar as preocupações, temores e profundas satisfações da vida pública aos encantos recônditos do lar. Para as mulheres, raramente existia essa 
dualidade; possuíam apenas e exclusivamente o lar, quadro "natural" de sua feminilidade. (HALL, 2009, p. 76)

A separação física entre trabalho e moradia, com a família se refugiando em uma villa afastada, assim como lemos em Misunderstood, não era algo inédito para o período. Ao analisar a vida dos Cadbury, Hall afirma que, se no começo dos anos 1800 "apenas os burgueses mais ricos podiam dispor de uma residência separada da empresa" (HALL, 2009, p. 57), isso não diminuía a vontade de separar a moradia do trabalho. Ao contar sobre a mudança de lorde Calthorpe para a villa de Edgbaston, na década de 1830, Hall adverte que o projeto não era exclusividade dos Cadbury.

O projeto de lorde Calthorpe, um dos primeiros em seu gênero, exprimia o desejo da burguesia de possuir uma casa particular e de separar a vida profissional da vida familiar, "as doces carícias e o afeto de uma mulher e filhos" das "preocupações e azáfama dos negócios. (HALL, 2009, p. 60)

O projeto, de acordo com o historiador Phillipe Ariès, não seria sequer exclusividade da Inglaterra, sendo observável em diversas regiões, com temporalidades um pouco distintas.

A partir de uma certa época, variável de um lugar para outro, mas que começa no fim do século XIX, isto é, antes do automóvel, os habitantes mais ricos fugiram da cidade aglomerada e densa, que consideravam ao mesmo tempo malsã e perigosa. Buscaram longe dos locais habitados um ar mais puro e uma vizinhança mais decente. (ARIÉS, 1981, p. 21)

Assim começa Incompreendido: os filhos na nursery esperando ansiosamente o retorno do pai, Sir Everard, que retorna à casa após período de ausência e é recebido pela governanta Virgine com "as lamentações daquilo que tinha feito M. Humphrey durante a semana anterior" e de como Miles tentava imitá-lo colocando em risco sua frágil saúde. (MONTGOMERY, 1960, p. 9)

\section{2. A construção discursiva da criança incompreendida em Misunderstood}

Em nossa análise, analisamos o livro um acontecimento, uma vez que se trata de um discurso efetivamente pronunciado.

não a alma ou a sensibilidade de uma época, nem os 'grupos', nem mesmo as 'escolas', as 'gerações' ou os 'movimentos', nem mesmo o personagem do autor no 
jogo das trocas que ligou sua vida à sua criação, mas sim a estrutura própria de uma obra, de um livro, de um texto. (FOUCAULT, 2014, p. 6)

Deste modo, o que nos interessa é uma análise de como os enunciados se articulam e quem pode legitimamente pronunciá-los. $\mathrm{O}$ enunciado central que analisamos aqui é o que de que a criança é incompreendida. No texto, Humphrey é apresentado como alguém que "do primeiro ao último momento fora um incompreendido" (p. 208). Mas como se constrói essa relação de incompreensão, esse enunciado de que a criança é incompreendida?

[Virgine] Não compreendia o menino: como podia compreendê-lo? Estava fortemente ressentida com ele por causa dos transtornos por ele causados, ignorava o quanto tinha ele sofrido, e a alegria rumorosa do menino constituía a seus olhos uma prova a mais da sua aridez de coração. (MONTGOMERY, 1960, p. 141)

O texto de 1869 constrói Humphrey como incompreendido inicialmente apresentando um desajuste entre a percepção do pai de que o menino não teria "coração" e a realidade vivida efetivamente pelo garoto. De acordo com o texto, isso seria um erro de interpretação daqueles que, como o pai, viam o menino apenas em seus momentos de distração.

- "Não parece ter muito coração", comentou intimamente, observando a figura de seu primogênito, que, vestido de louro, perseguia os cordeiros pelos prados.

Sir Everard constatava que o menino continuava o mesmo porque o via em seus momentos de olvido, quando a natureza e a infância reclamavam os seus direitos e a índole exuberante da criança permitia-lhe afastar o pensamento da sua dor; mas não $o$ via transfigurar-se quando o assaltava a lembrança; não ouvia o apelido familiar, pronunciado pela metade e sufocado por um soluço. (MONTGOMERY, 1960, p. 12)

Em outro momento, na igreja, o filho prefere não ficar próximo ao pai, sentando-se um pouco mais distante, no lugar que era ocupado pela mãe, e o enunciado se repete:

Mas Sir Everard tinha em vão pedido ao filho para sentar-se junto dele; o menino preferia o isolamento. Certa vez ocorreu ao viúvo que isso poderia acontecer devido ao fato de ter sido aquele o lugar de sua esposa, mas nunca acreditara que Humphrey tivesse muito coração ou sentimento e concluíra que devia tratar-se de um simples capricho, mesmo porque nunca se dera ao trabalho de interrogar o filho sobre o fato. (MONTGOMERY, 1960, p. 12)

Desta vez, ainda, percebemos que a incompreensão do filho se deve à falta de iniciativa para o diálogo por parte do pai, que não teria nunca perguntado ao filho o porquê de seu comportamento. Se a criança é incompreendida porque há um descompasso entre a percepção do pai e a realidade, a responsabilidade é apontada inicialmente como sendo do pai, que deveria ter perguntado. O governo da criança é realizado à distância, pela educação 
dos pais, uma vez que a construção da incompreensão da criança é acompanhada da norma para evitá-la: a ação do pai em buscar proximidade e diálogo.

O pai se preocupa, mas não pergunta. Não se trata de ausência de afeto ou de preocupação, mas da construção de que afeto não basta: é preciso ouvir a criança.

Sir Everard Duncombe ficou sentado ainda um pouco depois da função: olhava o rosto sério de Humphrey e procurava imaginar o que estaria pensando o pequeno. Quando o pastor se retirou, levantou-se e dirigiu-se para a saída. (MONTGOMERY, 1960, p. 36)

Humphrey é incompreendido porque é percebido como alguém que não tem coração, quando na verdade teria. Cabe analisar, portanto, como se constrói o enunciado de que Humphrey "não tem coração", com quais outros enunciados se articula?

O pai observa demonstrações de compaixão do filho quando Humphrey resolve passar na frente da casa de Tom, "o capenguinha", para dar-lhe dinheiro para uma muleta (p. 157) ou quando junta dinheiro para comprar uma corneta acústica ao velho Dyson (p. 99) que já não ouvia bem. Nas duas situações o pai está presente e acompanha o filho, mas as passagens não caracterizam o filho como alguém que tem coração. Não ter coração, portanto, não está relacionado à falta de compaixão.

O enunciado de que o menino "não tem muito coração" coexiste e se liga aos enunciados de que, na percepção do pai, ele não seria capaz de sentir a dor da perda da mãe, mas sobretudo de que não seria capaz de sentir culpa ou remorso pelos danos que suas próprias ações causavam ao irmão e aos outros. Deste modo, o enunciado "falta de coração" é construído em sentido mais específico como um problema relacionado a essas características que permitem que um indivíduo se considere responsável por seus próprios atos.

- Por que não vieste ajudar-me a vestir esta manhã? - perguntou-lhe Sir Everard, beijando-o.

Humphrey amarrou a cara.

- Virgine não o permitiu - respondeu; - pensou que fosse um bom castigo.

Eis a oportunidade! Sir Everard percebia que não convinha deixa-la fugir.

- Um castigo! - repetiu, tentando assumir um tom solene. - Desgosta-me saber que mereceste um castigo. Por quê? Que fizeste?

Humphrey olhou para o teto, depois para o pavimento, depois em volta do quarto.

- Não consigo lembrar, papai! 
Sir Everard esforçou-se para não sorrir. "De que servem as repreensões para tal menino? - pensou - um menino que não se lembra nem por que culpa mereceu castigo? (MONTGOMERY, 1960, p. 87)

Neste trecho, constrói-se de forma mais clara do que em outras passagens, uma oposição entre castigo e culpa. De que vale o castigo para uma criança que não sabe qual é a culpa que a fez merecedora da punição? Assim, a necessidade de que a criança seja compreendida se liga à necessidade de sair de uma esfera da disciplina e do castigo, associadas à figura da governanta, para se atingir um ideal de autocontrole e responsabilidade, que só seriam possíveis se a criança demonstrasse remorso ou culpa.

Quando, Miles, o irmão caçula, ficou doente por um descuido seu, Humphrey, impedido de entrar no quarto para que o irmão pudesse repousar, se pôs ao lado de fora a chorar, temendo que o irmão tivesse o mesmo destino da mãe. A cena construída neste momento retoma o conflito principal dando contornos precisos ao enunciado de que Humphrey é uma criança incompreendida: o menino, que é tão sensível, por sua natureza volúvel, parece aos adultos não ter coração. Coração, aqui, novamente, associado ao remorso.

E ele era muito bom de coração, pobre pequeno! Tão pronto ao remorso dos próprios erros; tão sensível a uma palavra dura, tão descuidado, apesar de tudo, tão volúvel que ninguém poderia crê-lo capaz de sentimentos profundos; até seu pai (embora não desejasse diverso, embora satisfeito da habilidade do filho de tornar alegre, para si próprio e para Miles, cada acontecimento de sua vida solitária), até seu pai o estranhava e mais de uma vez dissera a si mesmo: "Aquele menino não tem coração!"

Não tem coração! No entanto, enquanto o vemos lá, no corredor, o seu coraçãozinho está por arrebentar. (MONTGOMERY, 1960, p. 133-4)

O pai, quando pergunta, não presta atenção o suficiente no filho para perceber que este sente culpa e remorso. Ao ver o filho cuidando de uma gralha feia e brava, o menino conta por que continua alimentando-a, mas o pai, apesar de se preocupar em não chatear o filho, não é atento às suas explicações que demonstram culpa.

E se não fosse por minha culpa - acrescentou como que falando consigo mesmo - a estas horas ainda poderia voar.

Sir Everard não apanhou as últimas palavras, mas o rosto do menino fez-lhe ver que tinha tocado um ponto delicado e, assim, tratou de mudar de assunto, propondo-lhe irem juntos ao povoado. (MONTGOMERY, 1960, p. 153) 
A incompreensão da criança se constrói a partir da falsa percepção da vivacidade do garoto, visto pelo pai sempre em momentos de brincadeira, como ausência do remorso, da culpa e da saudade da mãe.

Rosenthal argumenta que o livro Incompreendido constrói uma imagem das crianças entre dois pólos, nem como racional, nem como irracional, mas como "troubled by fears which they can neither understand nor communicate to adults". (ROSENTHAL, 1975, p. 98) O papel dos pais, portanto, seria o buscar essa compreensão do que a criança não consegue expressar de forma clara, mas que seria possível perceber se observado com atenção. Nos momentos finais de Humphrey, após lamentar a ausência irreparável da mãe e constatar a inevitabilidade de sua morte, há um momento de ponderação do pai.

Mas percebia ter-se enganado; tinha ficado satisfeito quando seus meninos estavam bem e eram alegres, contentara-se de não ir mais além e tinha ficado no escuro de tudo aquilo que as simples palavras de Humphrey lhe estavam revelando. (MONTGOMERY, 1960, p. 213).

A norma de cuidado toma forma: seria preciso estar presente e disposto a escutar as crianças para tentar compreender a "complexidade de seus caracteres" a partir das daquilo que crianças revelam em suas "simples palavras" (MONTGOMERY, 1960, p.213). A construção da criança incompreendida, portanto, propõe uma conversão do olhar. A causa da incompreensão é construída como um erro de percepção daqueles que consideram, de forma errada, que a criança, por sua natureza volátil não demonstraria culpa e remorso a ponto de poder se responsabilizar por seus próprios atos. Assim, é preciso que aquilo que em um primeiro momento era visto como um sintoma da "ausência de coração", fosse então visto como um sintoma de uma natureza própria da criança.

Dizendo isso, virou a cabeça, porque a alusão ao jantar dos eleitores tinha-lhe evocado a imagem do menino irrompendo a biblioteca, cheio de vida, de saúde, de beleza; e por um instante sentiu-se oprimido pelo contraste com a figurinha definhada que jazia ali. (MONTGOMERY, 1960, p. 223).

O texto ensina que a vivacidade da criança não deve ser vista como ausência de responsabilidade moral, de capacidade de sentir culpa, remorso; pelo contrário, deve ser entendida como sinônimo de uma vida saudável e bela, uma característica natural, que pode sim ser governada, se não se restringir à educação disciplinadora. Mas como se constrói o enunciado de que essa vivacidade e movimento são naturais de Humphrey? 
Carlota Boto, a partir da leitura de Philippe Ariès, assinala a transformação, no século XVII, da criança de "adulto em miniatura" em "pequeno inocente":

\begin{abstract}
Do século XVII em diante, nota-se uma preocupação em afastar as crianças dos considerados jogos maus e reservar para a infância brincadeiras específicas, tidas como apropriadas à idade. Começava a aparecer o sentimento particular da infância como etapa específica da vida. Passava-se a se resguardar a criança, por pudor, de tudo o que se poderia considerar tema para 'gente grande. Sob tal compasso, a 'gracinha frágil' - ou o adulto em miniatura - seria substituída pelo 'pequenino inocente'. (BOTO, 2009)
\end{abstract}

Humphrey, por suas traquinadas, à primeira vista, dificilmente seria classificado como "pequeno inocente", sobretudo na comparação com Miles. A análise dos enunciados sobre a natureza de seu comportamento, porém, parecem resgatar a inocência de seu comportamento.

No livro, contrapõe-se o tédio ao movimento, construindo a imagem das crianças, sobretudo de Humphrey, como alguém que não consegue ficar parado, por sua própria natureza. Há, porém, uma oscilação nos enunciados relacionados ao movimento como característica natural, de forma que a vivacidade é apontada ora como específica de Humphrey em relação a Miles, ora como natural da infância, ora como ligada ao gênero e ora ligada à idade. Essa oscilação parece ocupar um papel significativo na incompreensão da criança, exatamente porque é onde o texto mais vacila entre explicações aparentemente contraditórias.

Logo de início, enquanto esperava o retorno do pai, o movimento e a vivacidade são apresentados como características da infância.

Que tarde tremendamente chuvosa! E tanto mais tediosa, para os dois pequenos, que esperam a volta do pai justamente naquele dia, e têm dele a ordem de ir buscá-lo na estação. (MONTGOMERY, 1960, p. 7)

Em outros momentos, como nas cenas em que o menino está de cama sem movimentos, a característica é apresentado como mais específico da natureza de Humphrey: "Cada um de nós reflita sobre a intensidade de tal momento para uma natureza como aquela!" (MONTGOMERY, 1960, p. 196).

Talvez o principal momento em que o movimento se coloque como algo próprio de Humphrey seja na indagação do pai sobre o que significaria a vida para o garoto:

Pois afinal, qual era o significado da palavra vida para Humphrey? Ai! As faculdades de que acabava de ser privado eram justamente os germes de sua existência: as coisas pelas quais ele se movia e tinha vida. Tirando-lhas, que lhe 
restava? Que seria a vida, sem elas? Que é uma casca da qual foi tirada a noz, um estojo que já não contenha a jóia? (p. 178)

Novamente, a comparação com outros animais sustenta que se trata de uma característica natural, mas natural de um indivíduo específico, natural de Humphrey:

\begin{abstract}
"As abelhas corriam de flor em flor, os pássaros se perseguiam de árvore em árvore, entre o zumbido incessante dos mosquitos; e Humphrey, a mais feliz e risonha de todas as criaturas da natureza, estava pois destinado a nunca mais brincar sob os raios do sol?

Pensou na irrefreável vivacidade do menino, no prazer que lhe vinha do movimento e do exercício físico. De manhã à noite, nunca parado, nunca cansado de correr ao ar livre. Nele houve sempre um gozo desenfreado da vida em si e por si, como se o simples fato de existir e de se mover encerrasse toda a felicidade. (MONTGOMERY, 1960, p. 180)
\end{abstract}

Quando a mãe fala dessa característica do filho, relaciona-a a uma suposta masculinidade: "Orgulhava-se dos seus modos másculos, da sua incansável atividade e do seu espírito pronto”. (MONTGOMERY, 1960, p. 10)

Miles, mais novo, também apresentaria características ligadas a uma suposta masculinidade, mas de modo distinto. Enquanto a masculinidade de Humphrey é produzida como associada à vivacidade, a masculinidade de Miles é produzida como relacionada à curiosidade.

Se Miles fosse uma menina, provavelmente sentir-se-ia satisfeito em passar aquela ilustração sem outras indagações; a mente das meninas apreende os conceitos de modo um tanto superficial. Miles, no entanto, como homem que era, levantou os grandes olhos profundos ao rosto de Joana com ar interrogativo. (MONTGOMERY, 1960, p. 39)

Por fim, quando o texto apresenta as lembranças da mãe, Lady Duncombe, como aquela que compreendia Humphrey, uma característica chama a atenção: a existência de algo como um desenvolvimento biológico das crianças. A oposição entre tédio e movimento seria, assim, mais forte em Humphrey do que em Miles porque seria uma característica ligada à idade.

- Humphrey tem três anos a mais - objetava Lady Duncombe; - não vais pretender que um menino daquela idade fique tranquilamente sentado como um pequeno que ainda não tem dois anos; nem por isso é menos afetuoso que Miles, embora de modo diverso. (MONTGOMERY, 1960, p. 10) 
A oscilação entre as explicações sobre o movimento como algo natural, portanto sinônimo de uma vida saudável e bela, ora sendo uma característica da natureza de Humphrey, ora sendo uma característica natural da infância, ora ligada à masculinidade, parece se estabilizar com esse enunciado, que coloca a vivacidade e o movimento como questões relacionadas à idade. Deste modo, a característica é ao mesmo tempo natural da infância e do gênero e específica de Humphrey em relação a Miles, por conta de sua idade.

Lady Duncombe, portanto, alerta que o enunciado "Humphrey não tem muito coração" seria inválida, seria um erro de percepção, uma vez que ele apresentaria seu afeto de modo diverso. O argumento usado para justificar as diferentes expressões do afeto, que estariam na base da incompreensão de Humphrey, seria o de que não se pode esperar dele um comportamento igual ao de Miles, sendo que têm idades diferentes. À cada idade corresponderia um comportamento e uma forma de expressar afeto.

Assim, o texto ensina ao leitor que a origem do comportamento de Humphrey está para além de sua vontade, que sua volatilidade e paixão pelo movimento não são sintomas da ausência de coração, da incapacidade de sentir culpa e remorso, que ele sente inclusive mais do que os outros: "naturezas como a de Humphrey não estão aptas para este mundo. Tal capacidade de dor não tem trégua aqui embaixo" (MONTGOMERY, 1960, p. 204). Quando o leitor, após uma conversão do olhar proposta pela narrativa, passa a ver as características de Humphrey não como má-vontade, mas como características naturais de sua masculinidade e de sua idade, a inocência de Humphrey é resgatada.

Mas, fosse apenas uma característica natural ligada ao gênero e à idade, como seria governada? Há uma outra característica construída como natural das crianças, que introduz a possibilidade de governo: o fato de imitarem. Na relação entre Miles e Humphrey, o conflito surge entre a natureza volúvel do mais velho e natureza tímida do mais novo que não conseguia dizer não ao irmão.

Tímido por natureza, Miles tornava-se afoito quando Humphrey dava a nota; obediente e submisso quando só, a um sinal de Humphrey criava coragem para desafiar Virgine e se tornava tão moleque quanto o irmão. (MONTGOMERY, 1960, p. 15)

A menção à imitação é recorrente: "Miles assustou-se àquela ideia, mas não gostava de dizer não" (p. 50). "Miles avançou timidamente. A ideia não lhe agradava muito, mas um 
ato de insubordinação ao irmão nunca lhe ocorreria.” (p. 121). O irmão mais novo, apresentado como alguém que imita, é perdoado pelas ações, que são vistas como culpa do mais velho.

Miles imita Humphrey. Humphrey imita o pai e os personagens das histórias do tio.

Quando o oficiante abriu o missal, Humphrey sentou-se no canto do banco imitando exatamente a posição do pai. Precisava sempre de um pouco de tempo para copiar a atitude do pai e, às vezes, mal o conseguia, Sir Everard cruzava uma perna ou movia a mão e, então, o pobre pequeno atrapalhava-se todo e precisava começar tudo de novo. (MONTGOMERY, 1960, p. 32)

O pai chega inclusive a afirmar ao tio, após suas histórias às crianças que "todas as aventuras que acabas de contar serão fielmente reproduzidas, caro Carlinhos, garanto-te. Virgine vai ter que fazer, coitada" (p. 48). A própria ação de escalar o galho podre sobre o rio, que leva à morte de Humphrey, é apresentada como inspirada pelas histórias de marinheiro do tio Carlinhos. "Como eram divertidas as histórias do tio Carlinhos! Comentou Humphrey com um suspiro. - Como gostaria de ouvi-las de novo! É uma pena que papai me tenha proibido de trepar naquele ramo. " (p. 160) No seu leito de morte, Humphrey pede ao pai, como último desejo, que jamais revele ao tio esse segredo. A culpa é apresentada, ao menos na relação entre adultos e crianças, como um fardo daquele que inspira, de quem dá o exemplo, e não daquele que imita. Humphrey, em seu último gesto, como prova final de que, ao contrário do que se achava, ele que tem coração, morre carregando a culpa do tio, livrando-o do fardo. "E ninguém nunca soube que o último desejo da criança fora que nunca, nunca o tio viesse a saber que fora sua história que lhe tinha dado a ideia do ramo que se debruçava sobre o lago das ninfas" (p.229).

É porque imitam, que este livro sobre a natureza da infância, pode ser um livro direcionado a adultos sobre como compreendê-las e governá-las. 


\section{3. Quem pode ocupar a posição de compreensivo e quem não pode?}

Qual é o status de quem, nesse texto, podia se colocar como alguém que compreende a criança? Em outras palavras, uma vez que a criança é discursivamente construída como incompreendida, quem era capaz de compreendê-la?

No livro Incompreendido, a mãe não é a única que compreende Humphrey. Há também a figura da lavadora Dolly, que teria flagrado o menino em momentos de explosão de sentimentos e sempre se posiciona ao seu lado, mas a mãe é a única, além da narradora, a enunciar uma explicação para a incompreensão do garoto: a incompatibilidade entre o comportamento esperado pelo pai e o comportamento próprio da idade do garoto. É também a única capaz de refrear os efeitos da incompreensão da natureza própria da maturação do filho: a disciplina excessiva do pai e da governanta Virgine, além de seus próprios impulsos disciplinadores. Assim, a mãe é a única que consegue permitir que o garoto se desenvolva de forma ideal, não um mosca-morta, mas um menino másculo, vivo, capaz de sentir remorso e culpa e de se autocontrolar e se responsabilizar por seus atos, uma vez que teria sido marcado pelos ensinamentos cristãos recebidos da boca da mãe durante a infância.

A narrativa não aponta contradição entre o enunciado de que "a mente das meninas apreende os conceitos de modo um tanto superficial" e o fato de que as únicas pessoas capazes de compreender Humphrey tenham sido Dolly, ainda que parcialmente, e a mãe. Essa ausência de contradição entre os enunciados nos leva a concluir que a compreensão não se coloca no texto como um problema intelectual, mas como uma habilidade de percepção natural da mãe, que, portanto, não poderia ser delegada, reforçando a produção da norma evidenciada por Hall de que a "as mulheres possuíam apenas e exclusivamente o lar, quadro 'natural' de sua feminilidade"' (HALL, 2009, p. 76).

A babá Virgine é, desde a primeira página, apresentada como excessivamente disciplinadora, tanto aos olhos dos filhos quanto aos olhos do pai.

Poder ficar longe de Virgine por muito tempo era o cúmulo da felicidade. Ela aparecia-lhes como um ente criado especialmente para ser obstáculo a qualquer projeto de divertimento. (MONTGOMERY, 1960, p. 8) 
No texto, constrói-se a oposição entre a visão de mundo das crianças e a de Virgine como uma incompatibilidade. Ela era a fiscal da lei, que dizia não a tudo: "um ente criado para prever perigo onde a eles parecia apenas haver recreio". (MONTGOMERY, 1960, p. 8) Virgine ocupa, na dinâmica da narrativa, um importante ponto de ancoragem como contraponto estratégico para a construção das virtudes dos membros da família.

Virgine é a realidade, enquanto o tio é maravilha. Contrapõe-se o mundo das maravilhas das histórias do tio Carlinhos e suas histórias de marinheiro à realidade de Virgine: "Oh! - exclamou Humphrey com um grande suspiro, descendo do reino das maravilhas à mesquinhez da vida de cada dia, ao ouvir o nome de Virgine" (MONTGOMERY, 1960, p. 47).

Virgine é séria, enquanto a mãe era amável. Ao contrário da babá, a falecida mãe, sempre com "ternos olhos" e "sorriso amável” (MONTGOMERY, 1960, p. 136) aparece no texto como aquela que compreendia o mais velho. Nos lamentos da ausência da mãe pela narradora, constrói-se uma norma de conduta, o ideal de maternidade pela constatação da carência:

Pobres cabecinhas sobre as quais uma mamãe amorosa não se abaixará nesta noite, murmurando doces palavras de ternura e bênção! Pobre rostinhos em que não encostará o demorado beijo materno! (MONTGOMERY, 1960, p. 25)

Também nesse lamento, pela comparação com outros animais, a presença da mãe é construída como natural e sua ausência como um distúrbio à ordem das coisas.

Fora nos prados, os cordeiros se deitam junto da ovelha; em cima, sobre as árvores, os pássaros aquecem-se ao torpor da asa materna; mas nenhum passo leve, nenhum ruge-ruge de saias, nenhuma lâmpada velada incomodará o sono sem sonhos dos dois irmãozinhos. (MONTGOMERY, 1960, p. 25)

A mãe é apresentada como alguém que possui uma vocação natural ao ensino sobre a palavra de Deus e esse ensinamento é visto como o princípio de moralidade que guia os homens públicos quando adultos. Deste modo, liga-se a educação da mulher ao equilíbrio social. Ao mesmo tempo, se a mãe é a responsável pela moralidade por conta de sua própria natureza, constrói-se a figura da mãe como insubstituível e a figura da governanta, consequentemente, como um problema.

Pobres pequenas inteligências, forçadas a depender de tal forma dos ensinamentos de uma criada ignorante! Obrigadas a renunciar, no desabrochar da infância, àquelas 
lições sobre a divina Verdade que para outros são dadas tão amorosamente e, ao mesmo tempo, tão naturalmente pelos lábios de uma mãe afetuosa, aquelas lições que ficam impressas no coração do homem tornado adulto por muito tempo depois que os lábios que as haviam pronunciado estão fechados para sempre.

Certo é que o poder de associação é grande e aquelas passagens das Escrituras que trazem ao menino a imagem viva da mãe, são as mesmas que, mais tarde durante a vida, continuam as prediletas e mais apreciadas. (MONTGOMERY, 1960, p. 41)

Após constatar a solidão e o desespero do incompreendido Humphrey, que "naquela hora tinha tanta necessidade de compaixão, e ninguém ia ao seu encontro" (p. 134), a narradora compara duas vezes a situação do rapaz à dos adultos, caracterizando os adultos como meninos que cresceram.

Meninos tornados adultos, mas meninos todavia, mesmo se dotados de raciocínio, quantos de nós não lutam da mesma maneira contra esse sentimento de raciocínio, quantos de nós não lutam da mesma maneira contra esse sentimento indefinível? (MONTGOMERY, 1960, p. 135)

Não parece haver aqui uma anulação das diferenças entre infância e idade adulta, tão marcada em outros momentos do texto, mas a construção de uma analogia: assim como as crianças precisam do cuidado da mãe, os adultos precisam do cuidado de Deus: "Como aquêle que é confortado pela mãe, assim eu [Deus] te confortarei” (MONTGOMERY, 1960, p. 138).

Após caracterizar os adultos como "meninos tornado adultos" (no original, "children of a larger growth, but children in understanding still", que seria, em tradução livre, "crianças de tamanho maior, mas ainda crianças no entendimento"), o texto continua afirmando que os adultos, o nós a quem o texto se endereça (ELLSWORTH, 2001), reagem da mesma forma à dor e marca essa dor como aquilo que nos movimenta em direção à sociedade.

Quando essa coisa misteriosa, que nós, com expressão mais amadurecida, chamamos dor (sorrow), nos assalta, o nosso primeiro pensamento não será: "Que fazer para afastá-lo?" Seja chamado pena, desespero, desilusão, angústia, preocupação, chame-se como se quiser, não tentamos nós sufocá-lo mudando de qualquer modo o fio dos nossos pensamentos? Não é esse mesmo sentimento que empurra o rico a frequentar a sociedade, a viajar, a atordoar-se, e o pobre à taverna? (MONTGOMERY, 1960, p. 135-6)

Se, como o texto afirma, só Deus pode aplacar a dor, a saída de casa com esse objetivo seria inútil. A família ocupa, portanto, um lugar privilegiado. A necessidade de formação moral religiosa das crianças pela mãe aparece justificada por garantir uma conduta 
correta do adulto, enquanto a vida em sociedade aparece como essa tentativa equivocada de aplacar a dor que deveríamos aplacar buscando a Deus. O critério da moralidade e da justiça não é social. Assim, a formação moral dos indivíduos não é feita para a vida em sociedade, mas para o juízo final.

Após o incidente em que o tio Carlinhos conta aos meninos que os "aborígenes" que o Sir Everard receberia em casa para jantar eram canibais e o incidente acaba com Humphrey chamando-os de selvagens, ele é encontrado em seu quarto chorando, porque "tinha medo que tio Carlinhos fosse para o inferno por ter dito uma tão terrível mentira, e ele não podia suportar a ideia" (MONTGOMERY, 1960, p. 85).

O homem (e não a mulher) deveria, de acordo com o texto, ter uma utilidade para a sociedade: "um homem pertence mais ao mundo que à própria casa; e a sua casa não deve ser obstáculo à sua missão de utilidade à comunidade humana" (p. 213). Deve ser útil para a comunidade, mas não é nela que encontra aquilo que aplacará sua dor. Essa dor só seria aplacada em Deus. E a formação sobre Deus é mais eficiente, “ficam impressas no coração dos homens tornado adultos" (p. 41), quando feita pela mãe.

O texto se aproxima, dessa forma, do discurso moral do evangelismo da época, que baseava suas mensagens "no pecado na culpa e na redenção", que via o mundo fora de casa como "lugar de orgulho e pecado" e a família como "centro da luta para reformar os hábitos e a moral", o que seria feito pela "assembleia religiosa familiar", que se torna o "alicerce da vida cristã". A moral familiar que se constrói na burguesia e vai se impor à gentry, está ligada a um evangelismo que, entre outros discursos, colabora para a divisão de funções baseada no gênero. (HALL, 2009, p. 49-52).

\footnotetext{
O compromisso religioso de criar um novo modo de vida, que possibilitava um cuidado constante com a vida espiritual e exigia que os membros da casa fossem praticantes, encontrou sua concretização material na progressiva separação e demarcação dos trabalhos masculinos e femininos.” (HALL, 2009, p. 49-52).
}

Os homens, que viviam do trabalho, no "mundo", deveriam ter um contato constante com o "lar moral" gerido pela mulher, de modo a neutralizar as tendências malignas. (p. 63) Elemento de moralização da masculinidade, a mulher se torna, portanto, a responsável pela moralização da sociedade. Observamos no texto, porém, que não é qualquer mulher que poderia ocupar essa posição. 
A mãe é uma senhora $(\operatorname{Lady})$. As criadas não são senhoras. Questionado pelo tio Carlinhos sobre Dolly, a mulher com quem gostaria de dançar na festa da colheita, Humphrey é enfático:

- Não é absolutamente uma senhora - respondeu Humphrey indignado; - é Dolly, a lavadeira; usa tamancos e as mangas arregaçadas, tem os braços vermelhos como o rosto. Dolly nada tem de senhora. (MONTGOMERY, 1960, p. 44)

E não adiantava abaixar as mangar que "nem assim é uma senhora" (p.45). Senhora, confidencia à Miles, só a mãe.

Não é uma verdadeira senhora, não aquilo que chamo uma senhora. Vês, Miles acrescentou baixando a voz e aproximando-se do irmão para que os outros não o ouvissem - nunca poderei fazer-te compreender, porque tu não te lembras da mamãe. (MONTGOMERY, 1960, p. 44)

Dolly, a lavadeira, aparece no texto quase como um ruído. Por tê-lo flagrado em um de seus momentos de seriedade, Dolly é apresentada como uma mulher que, ainda que não fosse uma senhora e não ocupasse o lugar da mãe, a única naturalmente apta a compreender o filho, seria capaz de compreender Humphrey.

\begin{abstract}
Os jardins eram junto da lavanderia e frequentemente, enquanto passava a roupa junto da janela, observava Dolly os meninos em suas brincadeiras e escutava involuntariamente suas longas conversas. Talvez fosse a única pessoa que tinha visto Humphrey em seus momentos de seriedade. Sem que êle o soubesse, tinha assistido a uma de suas raras explosões de sentimento na época da morte da Lady e, desde então, tornara-se um dos seus mais apaixonados defensores. Nunca poderá esquecer como o menino soluçara sobre a mostarda e o agrião semeados pela mãe e só demasiadamente tarde despontados! (MONTGOMERY, 1960, p. 127)
\end{abstract}

No texto, porém, apesar de se posicionar sempre ao lado do garoto, Dolly não elabora uma explicação sobre o porquê de sua incompreensão, nem sabe confortá-lo ou ajudá-lo. Tudo acontece como se, não sendo uma Lady, a compreensão de Dolly ou os efeitos que ela pudesse produzir fossem limitados, parciais.

A construção do ideal da mulher-mãe se entrecruza, assim, com a construção do ideal de senhora. Se, por um lado, a categoria de Lady parece indissociável da devoção à função do cuidado das crianças, por outro lado, isso não basta para que uma mulher seja considerada senhora.

O nome Adelaide é ainda significativo, uma vez que é o mesmo da rainha Adelaide Luísa Teresa Carolina Amélia (1772-1849), esposa de Guilherme IV, sucessores de Jorge IV 
e Carolina de Brunswick, a "rainha ultrajada". Como nos conta Catherine Hall, Adelaide e Guilherme IV formariam um "casal ideal”, em oposição ao casal anterior. O novo casal seria o marco de uma sociedade em que "já não admitia a licenciosidade dos costumes" e onde "o casamento e a família é que estavam na moda". A mãe falecida, ausência tão marcada no romance, leva o nome de Adelaide e não de Carolina. (HALL, 2009, p. 49)

Durante o século XIX, o código moral da burguesia passa a se impor inclusive sobre o código da gentry, substituindo, de acordo com Norbert Elias, um cânone das boas maneiras, por um cânone da moral.

O cânone comportamental da aristocracia foi um cânone de boas maneiras. Por esse mesmo cânone, os jogos amorosos estavam submetidos a certas regras; mas eles ainda tinham um lugar público na existência social dos indivíduos. O cânone comportamental das boas maneiras permitia falar e agir em matéria de sexo com bastante liberdade. A burguesia ascendente opôs ao cânone das boas maneiras outro modelo de civilização, o cânone da moral. Foi esse cânone que fechou todo o âmbito da sexualidade como uma das zonas mais perigosas, com uma malha diferenciada e fina de proibições, cuja observação rigorosa foi tratada como prova de status das famílias, assim como de seus membros individualmente. (ELIAS, 2012)

A rainha Adelaide e sua homônima mãe-falecida são representativas dessa mudança.

Por fim, Virgine é exagerada, enquanto o pai buscava o equilíbrio. O conflito do pai, Sir Everard Duncombe, se coloca da seguinte forma: por um lado, submeter as crianças à disciplina excessiva de Virgine comprometendo o desenvolvimento dos filhos e, por outro, não conseguir conter as traquinadas de Humphrey e colocar Miles em risco real que poderia levá-lo à morte.

Era preciso fazer alguma coisa para prevenir outros perigos para Miles. Mas o quê? Era evidente que não se podia confiar em Humphrey; e no entanto Sir Everard não podia admitir que se sacrificasse a vida dos seus meninos separando-os, nem obrigar Virgine a uma guarda severa. Era uma mulher nervosa e excessivamente inclinada a ver perigo em tudo que fizessem.

"É justo que os meninos se divirtam - refletia - e na idade de Humphrey é natural que cometam traquinadas. Não quero que se torne um mosca-morta. - Deu-lhe vontade de rir, sem querer, ao pensar em Humphrey mosca-morta. - E pensar que Miles poderia ter caído tão facilmente naquele lago! Teria sido suficiente um simples empurrão por parte de Humphrey, que nunca olha para onde vai, para o fazer cair. Nunca sairia de um banho tão completo. (MONTGOMERY, 1960, p. 146) 
O risco é reforçado, inclusive, pelo alerta do médico: "mesmo as maiores fibras não estão livres de acidentes tais" (p.184). Ao final, antes de morrer, novamente a figura dos médicos aparece. "Sir Everard acompanhou com o olhar aqueles grandes Médicos da Corte que, apesar de toda a sua ciência, nada podiam fazer para o seu menino; nada!" (p. 200) O conselho médico afirma que ninguém está livre pelas “fibras", a descrição da impotência dos médicos em relação ao destino no garoto alertam que ninguém está livre pelo dinheiro. Os dois enunciados, em conjunto, universalizam o risco, impondo que toda criança deveria ser governada. Da mesma forma, todos os adultos que delas se ocupam deveriam se preocupar em compreendê-las. Vale notar, também, que ainda que o médico tenha um papel importante ao universalizar o risco ao qual todas as crianças estão submetidas, não cabe a ele, nesse texto, dizer que a criança é incompreendida ou como compreendê-la.

De um lado o risco de morte, do outro o risco de transformar os filhos em moscas-mortas. A mãe aparece, nas lembranças de Sir Everard, como a única que era capaz de lidar com esse conflito. "Viu-a mais uma vez no ato de conter os seus temores maternos para não obstar no pequeno a paixão da aventura e não ser, com isso, uma sombra à sua felicidade.” (MONTGOMERY, 1960, p. 182)

O conflito entre risco de morte e risco de transformar os filhos em mosca-morta aponta para a formação de um ideal similar ao que Jacques Donzelot descreve ao caracterizar a infância da burguesia francesa do século XIX: a norma de uma liberação protegida.

E a infância? No primeiro caso, a solicitude de que é objeto toma a forma de uma
liberação protegida, de um resgate dos medos e pressões comuns. Em torno da
criança a família burguesa traça um cordão sanitário que delimita seu campo de
desenvolvimento: no interior desse perímetro o desenvolvimento de seu corpo e de
seu espírito será encorajado por todas as contribuições da psicopedagogia postas a
seu serviço e controlado por uma vigilância discreta. No outro caso, seria mais justo
definir o modelo pedagógico como o de liberdade vigiada. O que constitui
problema, no que lhe diz respeito, não é tanto o peso das pressões caducas, mas sim
o excesso de liberdade, o abandono nas ruas, e as técnicas instauradas consistem em
limitar essa liberdade, em dirigir a criança para espaços de maior vigilância, a
escola ou a habitação familiar. (DONZELOT, 1980, p. 44)

À norma de uma liberação protegida da infância burguesa Donzelot opõe a norma da liberdade vigiada da criança pobre. Enquanto para a burguesia o problema é o excesso de vigilância e de punições, para a criança das famílias operárias o que se constrói como problema seria o excesso de liberdade não vigiada. O livro Incompreendido produz um 
discurso sobre as crianças burguesas. O enunciado que identificamos de que a criança é incompreendida aparece, nesse momento, ligado à criança burguesa.

Neil Postman (1999) chega inclusive a afirmar que a ideia de infância quase chega a desaparecer nas classes baixas durante os abusos da Inglaterra industrializada. O sociólogo nos apresenta como exemplo da indistinção entre crianças e adultos o depoimento, entre outros, da menina Sarah Gooder, de oito anos, que trabalhava com medo no escuro de uma mina de carvão, para, depois, ressaltar que se não chegavam a uma "classe de pessoas", por outro lado, a ideia de infância foi mantida viva nas classes altas.

Houve várias razões pelas quais a infância sobreviveu à avareza da Inglaterra industrializada, e uma delas é que as classes média e alta na Inglaterra mantiveram a ideia viva, alimentando-a e difundindo-a. Esse fato não poderia ter sido do menor interesse ou consolo para Sarah Gooder. Mas é importante para a civilização mundial e especialmente para a Inglaterra. (POSTMAN, 1999, p. 68)

Mais do que a constatação da alteração de um modelo de vigilância punitiva para a norma de uma liberação protegida, é possível considerarmos as especificidades dessa norma na Inglaterra, no caso específico do livro Incompreendido e da emergência do enunciado da criança incompreendida em um romance literário. Um dos elementos específicos que chama a atenção é a função atribuída à mãe biológica nessa construção. Nos momentos finais de Humphrey, Sir Everard considera como tudo teria sido diferente com a mãe.

Refletiu na responsabilidade de criar filhos e na necessidade de viver sempre junto deles na esperança de compreender a complexidade dos seus caracteres; e tristemente considerou a irreparável perda que seus filhos tinham com a morte da mãe; quem os teria compreendido tão bem? (MONTGOMERY, 1960, p. 213).

O ideal é a presença da mãe, insubstituível. O pai não se culpava pela morte do filho, por considerá-la inevitável. Essa inevitabilidade é ligada, no texto, logo após o lamento pela ausência irreparável da mãe, ao fato dele ser homem e ter que, por isso, buscar uma vida de utilidade pública:

Não era de temperamento mórbido, e não se exprobrava por aquilo que fora inevitável: pois que um homem pertence mais ao mundo que à própria casa; e a sua casa não deve ser obstáculo à sua missão de utilidade à comunidade humana. (MONTGOMERY, 1960, p. 213).

$\mathrm{Na}$ ausência da mãe, que o compreendia naturalmente, a solução incompleta e parcial seria a presença do pai: "Por sorte - concluiu em alta voz - daqui a há pouco as sessões 
terminarão e eu poderei ficar aqui para vigiá-los.” (MONTGOMERY, 1960, p. 146) Aos olhos do pai, o ideal seria ter a capacidade de observar os filhos o tempo todo.

Todavia, não conseguia afastar aquele pensamento [de que Humphrey fosse ao lago tentar escalar o galho podre e levasse Miles] e, olhos fixos n'água, lamentava não pudesse existir algo parecido com aquele espelho mágico da história que tinha lido para os meninos, para poder ver até Wareham e tranquilizar-se a respeito. (MONTGOMERY, 1960, p. 170)

Mas, apesar da fantasia, o próprio pai apresenta dúvidas em relação ao excesso de controle. A ação disciplinadora é construída discursivamente de forma problemática, por um lado pelo risco de transformar a criança em mosca-morta e, por outro, porque, ainda que o tal espelho existisse, estar presente e se preocupar não bastaria se não conseguisse compreender "a complexidade de seus caracteres" (p. 213). O dilema de Sir Duncombe parece sintetizar as preocupações formativas do poder descrito por Foucault como disciplinar: como criar corpos ao mesmo tempo dóceis e eficientes? (FOUCAULT, 2015b)

A fim de solucionar este dilema, Sir Duncombe chega a desejar um espelho mágico que lhe permitisse observar o filho o tempo todo, mas logo considera que isso seria igualmente ineficiente. A solução para o pai está menos direcionada à vigilância constante e mais direcionada a possibilidade de internalização das normas. É preciso que Humphrey se construa como um sujeito psicologizado, capaz de se tornar seu próprio vigia.

A individualidade da criança entra no limiar de descrição do saber da época. A descrição da criança em sua autonomia relativa, em sua especificidade de criança, fazendo aparecer o enunciado da crianças incompreendida pelos pais, pode ser inscrita em um processo de transformação que Foucault denomina de "reversão do eixo político de individualização". Enquanto, num período anterior, esse ato de descrever, de transformar as vidas em registro, seria, de acordo com Foucault, um "procedimento de heroicização", agora ele agiria como "procedimento de objetificação e subjetivação". Não se descreve apenas o rei, mas a "individualidade cotidiana de cada um". "Ser olhado, observado, descrito em detalhe" deixa de ser um privilégio dos reis e "homens memoráveis" para se tornar um "meio de controle e um método de dominação" de homens calculáveis. (FOUCAULT, 2015b)

A descrição das especificidades da infância e a emergência do enunciado da criança incompreendida pelos pais se relaciona assim à construção do indivíduo moderno, livre e 
psicologizado, governado "através de suas liberdades, escolhas e solidariedades, e não apesar delas" (ROSE, 2011, p. 164).

\begin{abstract}
No século XIX, o governo se dirigia por uma ordem moral articulada em uma linguagem da epistemologia associacionista, da Filosofia Moral e das novas teorias psicológicas da patologia mental, Esse vocabulário interpretava a conduta individual como moldada pelos efeitos acumulados da exposição a influências virtuosas ou viciosas no início da vida, tendo estas um efeito duradouro na constituição e no caráter, sendo até mesmo comunicáveis às futuras gerações. $\mathrm{O}$ delinquente juvenil, por exemplo, teria contraído maus hábitos do meio moral corrupto do coração das grandes cidades. Tal delinquência poderia ser prevenida através da remoralização do ambiente doméstico, o qual consequentemente tornou-se foco de inúmeros projetos filantrópicos em Londres, Manchester e em outras cidades industriais britânicas e americanas (...) (ROSE, 2011, 103)
\end{abstract}

As influências do pai e do tio chegariam ao filho por meio do exemplo, que tem como condição de possibilidade o fato de uma das principais características atribuídas às crianças, Miles e Humphrey, ser a de imitar. As influências da mãe chegariam ao filho sobretudo por meio dos ensinamentos cristãos transmitidos de forma amorosa durante a infância de forma que seguissem certos princípios quando adultos.

Essa adequação do comportamento da criança a um conjunto de normas, pela imitação e pelo aprendizado religioso mediado pela mãe, só seria eficiente se as crianças fossem produzidas como indivíduos capazes de julgar a consequência de seus atos como resultado de suas escolhas, ou seja, de sentir remorso e culpa. Ele precisa "ter coração". Assim como o indivíduo moderno descrito por Nikolas Rose, Humphrey também precisa se constituir como uma criança psicologizada e moralmente responsável por seus atos, como "indivíduos que atribuíssem um certo tipo de subjetividade moral a si mesmos e que avaliassem e reformassem a si mesmos de acordo com essas normas” (ROSE, 2011).

A descrição de Humphrey como uma criança incompreendida pelo pai, permite ver na relação entre pais e filhos enunciada em Incompreendido, um processo de eticalização da autoridade (ROSE, 2011, p.131). O governo da criança através de sua relativa autonomia se exerce pela compreensão de sua suposta natureza, o diagnóstico dos elementos de inadequação e a prescrição do que deve ser feito para evitar o comportamento indesejado que se apresenta como um risco. 
A oscilação entre as características consideradas naturais da infância, da idade, do gênero ou do próprio Humphrey se aproxima bastante da descrição de Neil Postman sobre o século XIX, quando, de acordo com o autor, "o que parece ter acontecido é que começou a ser questionada a certeza da opinião sobre a natureza da infância”. (POSTMAN, 1999, p. 75) Postman relaciona essa ruptura à busca por uma matização entre as teorias da criança como tabula rasa, de John Locke, e da criança como próxima de um "estado de natureza", de Jean-Jacques Rousseau. É entre esses dois modos de olhar para a criança que teria surgido, de acordo com o autor, ideias como as da Sociedade para o Estudo da Natureza da Criança, que se colocavam perguntas como:

Deve-se impor obediência irrestrita às crianças? Como se pode transmitir à criança a verdadeira ideia de propriedade? Até onde deve chegar a autoridade das crianças mais velhas? Tolhe-se a imaginação da criança se se exige dela rígida adesão à verdade? (POSTMAN, 1999, p. 76)

As perguntas, de acordo com Postman, não estariam ligadas nem à concepção de Locke "de que as crianças eram adultos informes carentes de civilização", nem à de Rousseau, preocupada em "como proceder de modo a não prejudicar virtude infantis". Desse modo, "aceitavam a ideia de que há tanto uma lógica quanto uma psico-lógica da infância que devem ser respeitadas". Esse conflito entre as teorias de Locke e de Rousseau e o questionamento sobre as certezas em relação à natureza da infância teriam, de acordo com o autor, montado o "palco" para a emergências das teorias de Freud e Dewey, cujos livros mais influentes são publicados em 1899. (POSTMAN, 1999, p. 75-6)

É nesse intervalo que se situa o livro Incompreendido e seus enunciados. A expressão "psico-lógica", que Postman utiliza em sua interpretação, não aparece em seu exemplo, nem no livro Incompreendido. Porém, as explicações sobre as diferenças entre Humphrey e Miles descritas por enunciados que oscilam entre a natureza individual, a natureza da infância, a natureza masculina e as características naturais da idade se aproximam das perguntas feitas pela Sociedade para Estudos da Natureza da Criança preocupadas em não atrapalhar um desenvolvimento natural, que Postman descreve como uma "psico-lógica". Os problemas construídos discursivamente em Incompreendido têm outra proveniência que não os discursos filosóficos de Locke e Rousseau, mas, não obstante, compõem e apontam para uma parte 
menos nobre das condições de possibilidade para a emergência dos discursos sobre uma "psico-lógica" das crianças.

$\mathrm{Na}$ produção discursiva analisada, a compreensão não é monopólio de um saber médico, filosófico ou científico, mas da mulher-mãe, por suas características supostamente naturais e que têm como superfície de emergência um romance literário. A tensão construída na dinâmica própria do livro não é entre uma criança tábula-rasa ou uma criança com virtudes inatas, mas entre a disciplina excessiva que poderia levar à produção em uma criança mosca-morta e a falta vigilância, que poderia levar ao risco de morte. O problema que se apresenta, portanto, diz respeito à necessidade de transferir para a criança a capacidade de se autogovernar, de sentir culpa e remorso, características que o Sir Everard acreditava ausentes em Humphrey e que apenas a mãe conseguia reconhecer, sendo a única capaz, por suas características naturais, de compreender a complexidade dos caracteres de Humphrey e de equacionar o conflito educacional. À família, portanto, caberia compreender a natureza da criança que se diferencia daquela de seus outros membros. A criança já não é uma figura indiferenciada no seio da família.

\section{4. Individualidade relativa da criança}

Norbert Elias escreve que “A descoberta da infância é a descoberta de sua relativa autonomia." (ELIAS, 2010), quando as crianças deixam de ser vistas como adultos em miniatura para serem consideradas seres com especificidades e necessidades próprias e distintas das dos adultos. Assim, os gestos de indisciplina deixam de ser vistos exclusivamente como má-vontade ou desobediência. De certo modo, um livro destinado a adultos para mostrar-lhes a perspectiva da criança incompreendida é exemplar da consolidação dessa transformação. A criança é dotada de individualidade e se torna incompreendida pelos adultos.

No livro História Social da Criança e da Família, o historiador Philip Ariès, analisando a liberação dos retratos de família de sua função religiosa, chama a atenção para as ilustrações da vida familiar, no começo do século XVII, que retratam a família reunida à mesa: "a virilidade é ilustrada pela refeição que reúne toda a família em torno da mesa", "a 
idade viril é sempre a família”. A partir dessas e de outras observações, Ariès conclui pela emergência, nos séculos XVI-XVII do "sentimento de família". A multidão ou assembleia, personagem principal até o século XVI, perde gradualmente espaço, na iconografia, para a família. A vida em público da Idade Média perde lugar para a intimidade da família. (ARIÈS, 1981) A substituição de uma preocupação com a honra da ascendência começa a ser substituída por um cuidado com a descendência. A criança começa a deixar de ser vista apenas como perpetuação da linhagem para ser vista em suas individualidades, como escreve Carlota Boto (2009).

Segundo Ariès, a Idade Média não conhecera o sentimento de infância ao qual os tempos modernos nos habituaram. Pode-se dizer que a Idade Média identificava a criança mediante uma nítida representação da idéia de linhagem. Reconhecia-se o valor da infância pela projeção que a figura da criança ganhava quanto ao seu destacado lugar na perpetuação do sangue da família. (...) Os filhos não interessavam por suas individualidades, mas por serem portadores do germe da preservação familiar.

De acordo com esses autores, essa individualidade se refere à diferenciação entre a natureza dos adultos e a das crianças e ao sentimento de família, ligado ao foco na descendência em substituição ao foco na perpetuação da linhagem. Trata-se, como frisou Norbert Elias, de uma autonomia relativa, no sentido que é uma autonomia da infância como categoria e não de uma individualidade psicológica de cada criança no interior da família. No caso de Humphrey, sua individualidade é apresentada como uma configuração única, mas formada a partir de elementos genéricos: o fato de que imita, a natureza da idade, a masculinidade e as imposições dos adultos. Dessa forma, sua individualidade, "a complexidade de seus caracteres" (p. 213), pode ser compreendida em cada um desses aspectos de forma genérica.

Por um lado, a criança aparece como alguém que possui uma natureza distinta da dos adultos, por outro lado o poder de decisão sobre o que é ou não considerado uma vocação da criança aparece como monopólio do pai. Quando Miles, após ouvir as histórias do tio Carlinhos, questiona o pai sobre a possibilidade de ser marinheiro, o pai logo veta, com a seguinte justificativa: “- Bem, não me parece que seja esta justamente a tua vocação respondeu Sir Everard; - no entanto ainda tens muito tempo diante de ti..." 
(MONTGOMERY, 1960, p. 47). A individualidade da criança é, em Misunderstood, assim como afirma Norbert Elias, "a descoberta de sua autonomia relativa” (ELIAS, 2010). 


\section{Infância incompreendida, função materna reestruturante}

Um século depois da publicação do livro Misunderstood, de Florence Montgomery, o diretor italiano Luigi Comencini lança, em 1966, o filme Incompreso, traduzido para o português brasileiro como Quando o Amor é Cruel. Acompanhamos neste capítulo a reaparição, neste filme, do enunciado de que a criança é incompreendida pelos pais em relação com outros enunciados e observamos algumas rupturas e continuidades desse discurso.

Alargamos aqui a análise incluindo outros filmes que também tratam do objeto “criança incompreendida" nesse período: Noviça Rebelde (1965), de Robert Wise, e Mary Poppins (1964), de Robert Stevenson. Seguimos a sequência do livro Misunderstood (1869) ao filme Quando o Amor é Cruel (1966) e, depois, ao filme Incompreendida (2014) como um fio condutor por sua posição estratégica para pensar o enunciado de que a criança é incompreendida pelos pais, uma vez que são filmes que já trazem esse enunciado no título e que se remetem um ao outro, mas não nos limitamos ao livro ou aos filmes como operadores de síntese. Como sugere Michel Foucault em A Arqueologia do Saber, suspendemos temporariamente essas unidades "o livro", "a obra" para "podermos apreender outras formas de regularidade, outros tipos de relação. Relações entre os enunciados." Dessa forma, tomando os enunciados em suas relações e "libertando-os de todos os grupamentos considerados como unidades naturais, imediatas e universais, temos a possibilidade de descrever outras unidades", de pensar de outro modo, de tornar outras relações visíveis e refletir sobre elas. (FOUCAULT, 2014, p. 35)

Analisar o livro Misunderstood ao lado dos filmes Quando o Amor é Cruel (Incompreso), Noviça Rebelde e Mary Poppins neste capítulo e ao lado de outros filmes no capítulo a seguir, é, portanto, uma "decisão controlada" para fazer ver um conjunto de relações que "não seriam arbitrários, mas que, entretanto, teriam permanecidos invisíveis" caso se propusesse a analisar as unidades do discurso tradicionais como: a obra de um diretor autor, um livro, uma disciplina ou, no caso mais específico do cinema, a obra de um diretor ou um gênero fílmico específico. Assim, fazemos aparecer relações que "jamais teriam sido formuladas, por elas mesmas, nos enunciados em questão", mas que também não constituem 
um "discurso secreto, que animaria, do interior, um discurso manifesto". Antes, trata-se de um recorte sempre provisório, que permita fazer ver relações entre enunciados: “a análise de sua coexistência, de sua sucessão, de seu funcionamento mútuo, de sua determinação recíproca, de sua transformação independente ou correlativa". (FOUCAULT, 2014, p. 35-6)

\section{1. Quando o Amor é Cruel (Incompreso)}

O enredo do filme é aparentemente bastante semelhante ao do livro: o pai, Sir John Edward Duncombe, após a morte de Lady Duncombe, vive com os filhos: Milo, caçula, e Andrea, primogênito. Ele não consegue criá-los sozinho, recorrendo aos serviços profissionais de outras mulheres. O filme acaba igualmente com a morte do filho mais velho. Ao contrário do livro, porém, o filme não começa dois anos depois da morte da mãe, mas apenas alguns dias após o fato. A cena inicial é de Sir Duncombe conversando com o pastor sobre as crianças, Milo e Andrea, e planejando como tentará distrair o mais novo e criar coragem para contar ao mais velho sobre o ocorrido.

Pastor - Onde estão os garotos, Duncombe?

Sir Duncombe - Não estão aqui. Eu os mandei embora... para a casa dos Gill... assim que percebi que não havia mais esperança. Eles não sabem nada ainda. $\mathrm{E}$ Andrea? Eu direi a ele... Andrea já é grande. Ainda não sei como, mas vou tomar coragem. Milo? Tentaremos distraí-lo.

(COMENCINI, 1966)

Com a ausência da mãe, a babá Luisa é chamada para ficar com as crianças e logo são apresentados. Uma diferença notável entre a governanta Virgine, do livro de 1869, e a babá Luisa, do filme de 1966, aparece logo de início. Ao apresentá-la aos filhos, entre as funções da babá está "brincar".

Sir Duncombe - Apresento-lhe meus dois filhos. Este é Milo...e este Andrea. Esta é a senhorita Luisa.

Milo - Para que ela está aqui?

Sir Duncombe - Bem... Ela vai vesti-los, dar-lhes comida... Fará companhia a vocês... E... brincará com vocês.

(COMENCINI, 1966)

A babá é, inclusive, comparada à Mary Poppins: 
Dora - Ela é boa e conhece muitas brincadeiras.

Senhorita Luisa - Muitas!

Milo - Como Mary Poppins?

Senhorita Luisa - Claro!

(COMENCINI, 1966)

Milo logo questiona: "Se ela faz tudo, o que fará mamãe quando retornar?". O pai, porém, apenas responde que "Tenho certeza que logo vamos nos entender" sem mais explicações. A função da mãe e da babá são construídas como sendo, ao menos aos olhos de Milo, similares, não havendo necessidade das duas.

Apesar da apresentação focada no brincar, a babá Luisa é construída ao longo do filme como disciplinadora. Ela obriga Andrea a comer a comida de que não gosta e Milo a descansar. "Seu pai quer que Milo descanse às tardes... E tenho que respeitar suas ordens. Entendido?" Depois, quando Andrea pedalava a toda a velocidade e a babá lhe ordena que pare, o menino insulta e culpa-a por ter quebrado sua bicicleta. Para a babá Luisa, foi o ápice: “Já aguentei o bastante. Vou embora! Que seu pai arranje outra. Não aguento mais!” Andrea, ainda bravo, faz um pacto com Milo: "mesmo que ela se desculpe, vamos mandá-la embora". E ainda acrescentam: "Certo, agora somos livres. E se vier outra, a mandamos embora também. Vamos mandá-las todas embora com chutes na bunda." Durante esse enfrentamento entre Andrea e a babá Luisa, o primogênito lembra da mãe:

\footnotetext{
Andrea - Mamãe adorava quando eu corria com a minha bicicleta. Milo - Verdade?

Andrea - Era ela que me encorajava. "Mais rápido, Andrea! Corra, pedale! Tem que bater o recorde." E olhava para o relógio. E... dava-me um prêmio... E agora essa imbecil... Que direito tem?
}

A comparação evidencia que, ao contrário da babá, a mãe era capaz de equacionar a disciplina com os estímulos e que, aos olhos do garoto, só a mãe teria direito de lhe dar ordens, por ser mãe.

As lembranças da mãe são diferentes. Se no livro de 1869 a mãe é descrita como naturalmente amorosa e afetuosa (MONTGOMERY, 1960, p. 41), agora as características marcantes são a alegria, a beleza e o estímulo positivo. Ao contar da mãe a Milo, Andrea diz: "Eu me lembro que ela ria. Sempre estava alegre." Também quando, junto do pai, no consulado, vê uma foto da mãe triste, diz: "Mamãe está mais bonita no retrato que temos em 
casa. Aqui está triste.”. Ao que o pai responde: "Sim, tem razão. Ela não era assim." (COMENCINI, 1966)

Ainda, sobre a lembrança da mãe, em um diálogo entre os irmão, Andrea fantasia que a mãe está presente: "Mamãe... faz o que fazia aqui conosco. Prepara o café da manhã, com pães e manteiga... passa o batom nos lábios... e todos a obedecem, porque é belíssima." A obediência à mãe não se liga à sua austeridade. Na cena seguinte, o pai conversa em particular com Andrea, que já sabia da notícia que receberia e que reage sem desespero para a surpresa do pai:

Sir Duncombe - Eu pedi para que dissessem...que mamãe teve de partir, de repente. Mas não era verdade. Ela estava aqui em casa. Doente... e... durante sua ausência... ela piorou. E agora... entende, Andrea?

Andrea - Entendo. Os Gill falaram baixinho... mas eu os ouvi.

[O garoto mexe nos objetos.]

Sir Duncombe - Pare com isso! Melhor assim, Andrea. Fico contente com sua valentia. Eu sabia que você era forte, na verdade... decidi dizer-lhe que...mamãe já não está aqui. Mas não imaginava que fosse tão bravo. Melhor assim... tudo será mais fácil na sua vida.

(COMENCINI, 1966)

Ao contrário do livro de 1869, no filme, a capacidade de sentir remorso é identificada desde o começo no primogênito e, portanto, não faz parte de sua construção discursiva como incompreendido: "Quer saber por que não consegue dormir? Está com remorsos pelo que fez hoje." (COMENCINI, 1966)

A imitação como princípio gerador dos problemas de comportamento e como abertura de possibilidade para o governo à distância da criança pela educação dos pais também não reaparece na versão cinematográfica. Mesmo a ideia de se pendurar no galho sobre o lago, que acaba levando Andrea à morte, não é inspirada nas histórias do tio, mas parte do próprio garoto, como podemos observar no diálogo entre os irmãos:

\footnotetext{
Andrea - Sabe o que é aquele galho?

Milo - É um galho que caiu.

Andrea - Não, é um 'audaciômetro'.

Milo - O que é um a-auda-ciômetro?

Andrea - Olhe bem. Se eu me penduro aqui, não acontece nada. Não range porque não há nenhum perigo, mas se depois faz 'crack'. Eu já cheguei em dois 'cracks'. Quero ver se chego no terceiro. Se eu chegar no terceiro bato meu recorde.
}

O mesmo acontece com a iniciativa de ir à cidade. Enquanto no livro do século XIX é o pai que leva Humphrey (nome do filho mais velho no livro, que muda para Andrea no 
filme) e aguarda enquanto ele compra seu presente, aqui é o próprio Andrea que foge para a cidade para comprar o presente sozinho e fazer uma surpresa ao pai. A cena na cidade se desenrola com Milo insistindo para ir junto com Andrea. A compra demora mais do que o esperado, os dois voltam correndo de bicicleta e se seguram em um ônibus para ganhar velocidade e chegar em casa antes do pai. O carro do pai, dirigido por seu motorista, ultrapassa os garotos, que ele não reconhece:

\footnotetext{
Sir Duncombe - Que inconsequentes! Mas... é o Andrea... e o Milo também! Chegando em casa, o pai adverte o filho:

Sir Duncombe - Você é incorrigível, não tem nenhum senso de responsabilidade.
}

Como podemos perceber, apesar de haver continuidade no enunciado de que a criança é incompreendida, os outros enunciados com os quais se articula não são os mesmos. Deparamo-nos, aqui, com uma das consequências de empreender um projeto foucaultiano de descrição dos acontecimentos discursivos, tal como o autor sugere em A Arqueologia do Saber, a saber: o aparecimento do descontínuo.

\footnotetext{
Um dos traços mais essenciais da história nova é, sem dúvida, esse deslocamento do descontínuo: sua passagem do obstáculo à prática; sua integração no discurso do historiador, no qual não desempenha mais o papel de uma fatalidade exterior que é preciso reduzir, e sim o de um conceito operatório que se utiliza; por isso, a inversão de signos graças à qual ele não é mais o negativo da leitura histórica (seu avesso, seu fracasso, o limite de seu poder), mas o elemento positivo que determina seu objeto e valida sua análise. (FOUCAULT, 2014, p. 10)
}

O enunciado de que a criança é incompreendida reaparece, mas ligado a outros enunciados. Deste modo, ao mesmo tempo em que podemos constatar uma continuidade na construção discursiva das crianças, a partir de um regime de verdade, como incompreendida, é possível, igualmente, marcar que há uma descontinuidade na forma como esse enunciado é construído e como opera em cada momento. A construção discursiva da criança como incompreendida aparece em Quando o Amor é Cruel, assim como no livro Misunderstood, ligada ao enunciado da ausência de responsabilidade. Porém, enquanto no livro o pai suspeita que a suposta incapacidade do filho de ser responsável se deva a sua "ausência de coração" e à incapacidade de sentir remorso, no filme de Comencini o enunciado com o qual coexiste é o da criança imprudente, inconsequente, que não seria capaz de pensar na consequência de seus atos. Além do grito do pai, a questão aparece com ironia na cena seguinte quando o pai 
finalmente abre o presente: um relógio com a foto dos garotos e a inscrição "seja prudente, não corra". O pai, ao receber, questiona:

\begin{abstract}
Sir Duncombe - Então eu deveria ser prudente, é?
Andrea - Manda-me para o colégio, papai. Sou muito ruim.

Sir Duncombe Você não é ruim. Simplesmente é assim. As coisas não te afetam, elas resvalam... Não vi você sofrer nem sequer quando... então lhe disse que era sorte você ser assim, mas tenha cuidado, não exagere. Porque em algum momento, sem querer, poderia machucar seu irmão. Agora vá.
\end{abstract}

(COMENCINI, 1966)

O moralismo evangelista do livro está completamente ausente do filme. O menino não tem digressões pensando nas missas e nas escrituras. $O$ fato de que as coisas lhe afetam, ao contrário do que acreditaria o pai, fazendo, portanto, do filho um incompreendido, é construído também por meio da cena de bebedeira e da ajuda do tio.

Há no filme um evento inédito, um gravador que teria a voz da mãe conversando com o pai, que lhe pede para recitar uma poesia. Andrea encontra o aparelho e fica escondido escutando a voz da falecida mãe, mas eventualmente comete um erro e apaga o conteúdo da fita. O menino, então, procura um técnico na cidade, mas o senhor lhe informa que não será possível recuperar o conteúdo. Quando o menino lhe explica que se tratava da única gravação com a voz de sua mãe, que está morta, o senhor serve-lhe uma bebida e o garoto volta embriagado para casa. O tio encontra o garoto, percebe a situação e o ajuda a vomitar no banheiro e dormir. O tio sabe que o menino sofre. É um elemento externo ao núcleo familiar restrito e que permite construir discursivamente a incompreensão do garoto pelo pai. A diferença entre a percepção do pai e essa outra percepção permite que se construa o enunciado de que o garoto é incompreendido. A figura externa colabora na construção dessa imagem por flagrar o menino em momentos espontâneos de sofrimento e preocupação que o pai é incapaz de perceber por não estar presente e não dialogar. Continuidades em relação ao livro. A diferença é que neste filme a questão pode ser solucionada. O pai pode se conciliar com o filho a tal ponto que lhe é suficiente.

A diferença entre as percepções se evidencia, após a bebedeira, no diálogo entre o pai e o tio:

Sir Duncombe - Veja Andrea. O mundo poderia acabar e ele continuaria brincando. William (tio) - Acho que você está enganado, John. Andrea é como um cãozinho sem dono. Tente acariciá-lo...

Sir Duncombe - Andrea não é um cão. É um menino... e gostaria que ele tivesse reações humanas. 
William (tio) - Não quero ofender nem crianças nem cães, mas ambos precisam de um dono.

Sir Duncombe - Tentei me tornar amigo dele.

William (tio) - Amigo não, John. Dono. Faça com que leve um jornal na boca e verá como ficará feliz.

Sir Duncombe - Ah, Will. Não consegue falar sério nunca?

William (tio) - Não, mas me calarei. Você já me entendeu.

(COMENCINI, 1966)

É nessa assimetria entre as percepções que o pai e o tio têm do garoto que se constrói a incompreensão do pai. O tio teria flagrado o menino em momentos de dor, enquanto o pai só o perceberia em momentos de distração.

$\mathrm{Na}$ cena seguinte, o pai chama o garoto para lhe ajudar no consulado e Andrea pode escolher entre ir ver carros com Milos e o tio ou ajudar o pai a abrir cartas no consulado, construindo-se, pela proximidade entre as cenas, uma relação entre fazer o cãozinho trazer o jornal com a boca e chamar o filho para ajudar no trabalho. O filho escolhe ajudar o pai. A sequência constrói, desta forma, a percepção do tio como verdadeira. A mesma cena já traz elementos da construção de uma possível conciliação entre pai e filho.

O problema central da incompreensão do filho pelo pai em Quando o Amor é Cruel não é mais o de uma percepção equivocada sobre a natureza de uma criança em movimento, altiva, como irresponsável e "sem coração", mas o da percepção equivocada do filho como inconsequente. Perguntamos, então: como se constrói discursivamente esse enunciado do filho inconsequente, a que outros enunciados se articula?

No filme, a inconsequência está fortemente ligada à ideia de que o perigo de se pendurar no galho, como diz Andrea após o acidente, "ajudava-me a acalmar os nervos". A morte da mãe, a falta da mãe, causa em Andrea ataques de nervos, explosões de emoção que ele não consegue controlar.

O filme ainda sugere que tanto as explosões quanto a indisciplina de Andrea seriam amenizadas pela presença de um adulto que fosse capaz de canalizar essa força. A figura que desempenhava esse papel, a mãe, morreu. Porém, o pai pode, ao menos teoricamente, ocupar esse papel. Há conciliação. Tardia, mas há.

Sir Duncombe (lendo a carta de Andrea) - Sem dúvida nenhuma, meu melhor amigo é meu pai. Naturalmente, é mais velho que eu, mas isso não tem importância. É muito alto e muito forte. Pode levantar-me facilmente com uma mão e fala muitos idiomas. Além de pai e filho, somos muito amigos e nossa amizade se baseia em muitas coisas. Por exemplo, brincamos muito juntos e entre nós não existe nenhum 
segredo. Se me sinto triste, ele imediatamente me compreende. Então, me pega em seus braços e me diz...

Sir Duncombe (para Andrea) - Por que não terminou?

Andrea - Você nunca me diz nada.

Sir Duncombe - Quer que acabemos juntos? Por favor, vamos tentar.

Andrea - Se quiser.

Sir Duncombe - Claro, agora mesmo. Vejamos como continuar... "Me pega em seus braços e me diz: "Filho, me perdoe, porque não é verdade que seu pai sempre te compreendeu. Ele estava tão cego por sua dor, que não se deu conta de que... você também sofria, quem sabe mais que ele." Não é verdade? "Papai demorou muito para entender isso. Tempo demais. E isto é triste... imperdoável... Mas a partir de agora seremos grandes amigos porque agora é ele quem lhe pede, e está orgulhoso de pedir-lhe. Você é o filho que qualquer pai gostaria de ter."

Andrea - O que diz... é verdade, papai? Você verá... vou me recuperar... E já não me importo que não possa andar... Mas me sinto tão fraco. Então... ainda que eu não sobreviva, não fique triste. Quando mamãe... se foi... eu fiquei com você. Mas se agora mamãe me quer...

(..)

Milo - Papai, ele dormiu?

Sir Duncombe - Sim.

Milo - Ele vai acordar se eu lhe der um beijinho?

Sir Duncombe - Não. Anda, volte a brincar.

[A câmera focaliza no retrato da mãe, coberto por um vidro que reflete Andrea, de modo que ficam unidos na imagem]

O momento de reconciliação é bem diferente. Se no primeiro o menino não suporta a ideia de viver sem se movimentar e quer morrer e encontrar a mãe, no segundo o menino, ao descobrir o carinho do pai por ele, resolve viver. Ele não liga para a ausência de movimento agora que tem o pai como amigo. Se ele vai é apenas porque a mamãe está "querendo companhia".

Quem pode compreender não é mais exclusivamente a mãe que teria uma habilidade supostamente natural, o que torna a pessoa da mãe biológica substituível. A conciliação tardia entre pai e filho e a morte do filho, porém, constroem a figura materna como sendo catalisadora desse processo. A figura materna seria responsável por conter os excessos disciplinadores do pai, que depois são exercidos por meio das ordens às babás, e reequilibrar o lar ensinando o pai a lidar com o filho. A construção discursiva da compreensão da mãe a coloca como alguém que entende que o filho, para não se tornar indisciplinado, precisa de estímulos e não de interdições.

Nesse ponto, o elemento do brincar se torna central. O ideal de babá é aquela brinca com as crianças, ainda que a promessa não se cumpra e a babá passe a ser mal vista pelas crianças. O ideal de pai, na visão do filho, o "pai-amigo", mas que não deixa de ser 
“pai-dono", no sentido construído pelo tio. O ideal de mãe é a mulher que estimula o filho e está sempre feliz.

A oposição entre a troca constante de babás sisudas e disciplinadoras e a figura materna que estimulava e estava sempre feliz, sugere que seria necessário mudar de estratégia para governar as crianças de forma eficiente. $\mathrm{O}$ filme, portanto, ensina os pais que a estratégia da interdição, da disciplina excessiva, não funciona mais e que é necessário que alguém ocupe esse lugar da mãe catalisadora para equilibrar a família de forma menos impositiva e mais compreensiva.

\title{
3. 2. Mary Poppins
}

Mary Poppins, de Robert Stevenson, é uma adaptação dos estúdios Disney dos clássicos de P. L. Travers escritos na década de 1930 para as telas. O musical foi um sucesso de bilheteria e de arrecadação tão incrível quanto inesperado:

\begin{abstract}
Entre agosto de 1964 e março de 1965, quatro filmes estreantes venderam tantos ingressos e faturaram tanto dinheiro que, coletivamente, representaram a afirmação de uma mudança drástica no gosto dos espectadores norte-americanos e a indicação da nova forma de atuação dos estúdios. Como sempre, Hollywood não reagiu muito bem. Historicamente, o único evento mais prejudicial ao ecossistema da indústria do que um fracasso inesperado é um sucesso inesperado e, pegos de surpresa pela entrada de mais dinheiro do que eles imaginavam que suas produções trariam, os grandes estúdios reviveram algumas de suas mais antigas características: imitação, especulação frenética e pânico.

Três desses filmes eram musicais - Mary Poppins, da Disney, Minha bela dama, da Warner, e $A$ noviça rebelde, da Fox. Quando saíram de cartaz, todos eles se tornaram a maior bilheteria da história de seu estúdio e, em 1966, A noviça rebelde superou $E$ o vento levou como a maior arrecadação da história do cinema.
\end{abstract}

(HARRIS, 2011, p. 77)

Mary Poppins conta a história da família Banks. O filme começa conduzindo os espectadores pela vizinhança. Passamos pelo lar do almirante Boom, aposentado da marinha, que registra todos acontecimentos em seu diário de bordo com pontualidade precisa e nos informa sobre o tempo: "previsão de tormentas para o número 17" (STEVENSON, 1964). É exatamente no número 17 , na rua das laranjeiras que entramos. "Residência de George 
Banks" diz o narrador. George Banks, o proprietário, é o pai da família, um banqueiro bastante rigoroso com a disciplina.

Entramos. Estamos em uma casa londrina do começo do século XX: espaço social no andar de baixo, quartos no andar de cima. A tormenta anunciada pelo almirante começa com a babá Katie Nana deixando a casa. Apesar de ambientada na virada do século, o filme é de 1964, com o olhar de 1964 sobre o passado. Não se fala governanta, fala-se babá. Como nos lembra Anne McLeer (2002, p. 81), mesmo quando os filmes se ambientam no passado, como é o caso de Mary Poppins, sempre falam sobre o momento de sua produção. Um filme é sempre sobre seu presente.

Duas mulheres presenciam a demissão da babá: Ellen e Sra. Brill, empregadas da família. O título de senhora já não carrega mais as distinções sociais observadas em Incompreendido (MONTGOMERY, 1869), e é utilizado para Sra. Brill, que trabalha para os Banks como cozinheira. É ela que tenta deter Katie Nana em vão. "Os pestinhas fugiram de mim pela última vez." (STEVENSON, 1964) Os "pestinhas", como descobriremos a seguir, são Jane e Michael Banks.

Katie Nana ainda está casa quando chega Sra. Banks cantando "Nossas netinhas vão nos adorar e em coro vão cantar: 'muito bem, irmã sufragista!'” (STEVENSON, 1964). Ela cumprimenta todas pelo nome e começa a contar como foi boa a reunião, que Sra. Whitbourne se acorrentou à carruagem do primeiro ministro, que Sra. Ainslie foi para a prisão entregando panfletos. Katie Nana tenta interrompê-la para falar sobre as crianças e sua demissão, mas Sra. Banks continua por algum tempo cantando músicas das sufragistas, "igualdade política, direitos iguais aos homens", "não seremos mais mansas, tolas e subservientes, lutamos por nossos direitos como militantes", "fora com as algemas do passado", até que Katie Nana, consegue interrompê-la e Sra. Banks percebe a ausência das crianças.

É a quarta vez que elas fogem essa semana. Katie Nana pede o dinheiro que lhe é devido, enquanto Winifred Banks, a Sra. Banks, apela em vão: “O que o Sr. Banks dirá?”, "Katie Nana, eu imploro. Por favor, pense bem. Pense nas crianças. Pense no Sr. Banks. Ele estava acostumado com você." (STEVENSON, 1964). O pedido é feito primeiro pensando em Sr. Banks, depois nas crianças. É também pensando na reação do marido que Sra. Banks pede para que guardem os adereços que trazia da reunião: "Ellen, guarde isso. Sr. Banks 
ficará furioso com esta causa.” Sr. Banks é construído, assim, como um personagem central da trama e como aquele que deveria ser agradado.

Enquanto ainda falam de Sr. Banks muda a cena e ele aparece chegando em casa. Conversa com almirante Boom no caminho sobre a força da libra inglesa, sobre o dinheiro e forte e como tudo vai bem. Ele entra em casa cantando:

\begin{abstract}
Sinto uma onda de pura satisfação. Feito um rei montado em seu corcel. (...) Quando volto da rotina para o meu lar confortável. Que vida mais agradável. (...) Pontualidade é meu dever. Às $18 \mathrm{~h} 01 \mathrm{eu}$ entro em casa. Meus chinelos, licor e cachimbo às $18 \mathrm{~h} 02$ devem estar prontos. Que vida mais estável a minha. (...) É ótimo ser um inglês em 1910. O rei Eduardo está no trono. É a era masculina. Sou o rei do meu castelo $\mathrm{O}$ soberano, o mestre. Trato meus criados, crianças e esposa com mão firme, porém gentil. Obrigações da aristocracia. São $18 \mathrm{~h} 03$ e os herdeiros sob meu domínio. Depois de devidamente limpos e adequadamente nutridos afago suas cabecinhas e os mando pra caminha. Que vida mais nobre tenho eu.
\end{abstract}

A trama se desenrola de forma quase dupla, como se as músicas e a narrativa tivessem modos de endereçamento (ELLSWORTH, 2001) distintos. Nesse primeiro momento, as questões políticas que estruturam a narrativa são especificadas apenas nas canções, de forma que uma criança poderia acompanhar a narrativa sem se ater a essas questões, observando apenas o relacionamento que irá se desenvolver entre a Mary Poppins e as crianças Jane e Michael; enquanto, provavelmente os adultos, que compreendem os termos "sufragista" e "soberano", acompanham a oposição entre uma Sra. Banks que milita pelos direitos femininos e um Sr. Banks que se considera "o rei de seu castelo" em uma "era masculina". Assim, para as crianças se constrói uma narrativa sobre uma babá, enquanto, para os adultos, se constrói uma narrativa sobre o papel da mulher e do homem na família.

É somente depois da canção que Sr. Banks se dá conta daquilo que as mulheres tentam lhe contar durante toda a canção: as crianças não estão. Ele chama prontamente a polícia. Enquanto ainda está no telefone, um policial chega à porta com Jane e Michael. O policial tenta amenizar a situação: "Não seja duro com eles. A caminhada foi dura e longa". As crianças explicam que a pipa voou para longe e que foram buscá-la. "A pipa não era das melhores. Nós mesmos fizemos. Se nos ajudasse a fazer uma...”. Na visão das crianças, portanto, o problema é a ausência do pai, que não os ajuda.

O pai não escuta nem o policial nem as crianças, dispensando-os para as empregadas. Ordena que Sra. Brill sirva algo ao policial na cozinha e que Ellen suba com as crianças para o quarto. A conversa continua entre Sr. e Sra. Banks com a mulher se justificando ao homem. 
A visão das crianças de que o problema é a ausência do pai não é compartilhada pelo casal, ainda que seja construída como a versão verdadeira dos acontecimentos, por ser a visão que estrutura a narrativa e que definirá o efeito de fechamento (BORDWELL, 2005) do filme.

Sra. Banks lamenta ter se enganado a respeito de Katie Nana e diz que acertará na próxima vez. Sr. Banks, porém, argumenta que já é a quarta babá em seis meses, que escolher uma babá "requer perspicácia, bons critérios e julgar bem a personalidade" (STEVENSON, 1964) e que, portanto, ele mesmo se encarregará da tarefa colocando um anúncio no Times. Sr. Banks, então, dita a carta à esposa:

Sr. Banks - Procura-se, não, requisitamos. Babá: com pulso, de respeito. sem bobagens. [Continua em forma de canção]. Uma babá inglesa deve ser um general O futuro do império está em suas mãos. Precisamos de alguém, então, que dê boa educação. Uma babá que imponha ordens. Está anotando, Winifred?

Sra. Banks - Tudinho.

Sr. Banks - Um banco inglês precisa de boa administração. Um lar inglês merece a mesma atenção. Tradição, disciplina e regras devem ser as ferramentas. Sem elas, há desordem, catástrofe, anarquia. Resumindo, uma bagunça total.

Sra. Banks - Excelente, George. O jornal vai adorar.

Logo após o pai comparar a função de babá com a de um banqueiro, destacando "tradição, disciplina e regras" ao mesmo tempo como suas qualidade e como as qualidades necessárias para educar seus filhos, aparecem as crianças. Elas se desculpam pela demissão da babá e como forma de se redimirem, escrevem um anúncio para a próxima babá:

Jane - Precisa-se de uma babá para duas crianças adoráveis.

Sr. Banks - Adoráveis. Isso é questionável.

[Continua forma de canção.]

Jane - Para trabalhar nesta posição. Tenha uma alegre disposição.

Sr. Banks - Jane, eu não...

Jane - Rosto corado, nada de verrugas.

Michael - Eu coloquei essa parte.

Jane - Fazer brincadeiras, todas. Tem que ser amável. Tem que ser esperta. Muito meiga e adorável.

Sr. Banks - É ridículo..

Sra. Banks- George, por favor.

Jane - Deve nos levar para passear. Dar-nos presentes. Gostar de cantar. E trazer doces. Nunca ser severa ou ficar irritada. Nunca dar óleo de rícino. Nem mingau. Ame-nos como seus filhos. E que não cheire a água de cevada.

Michael - Também coloquei isso.

Jane - Se não se zangar e tentar nos dominar, nunca lhe daremos motivo para nos odiar. Não esconderemos seus óculos para não enxergar. Nem sapos na sua cama encontrará. Nem pimenta no seu chá. Venha logo, babá. Muito obrigado. Atenciosamente.

Jane e Michael (juntos) - Jane e Michael Banks.

Sr. Banks - Obrigado. Muito interessante. Basta de bobagens. Voltem ao seu quarto. 
As crianças apresentam o próprio comportamento como resposta ao comportamento da babá, de forma que se a babá não tentasse dominá-los, fosse carinhosa e brincasse com eles, não seriam "pestinhas".

Por meio da música, também se constrói uma norma de amor: amar "como seus filhos", ainda que todas as demonstrações desse amor descritas na canção sejam ausentes em seus próprios pais. É exatamente essa ausência que nos indica que os pais precisam de correção. O governo das crianças é exercido pedagogicamente, à distância, pela tentativa de conduzir a conduta dos pais.

Ser alegre, cantar e brincar. O ideal de babá de Mary Poppins se assemelha ao ideal materno de Quando o amor é cruel: "Eu me lembro que ela ria. Sempre estava alegre." Ambos, porém, se afastam em partes do ideal materno de Incompreendido, que conta as verdades de forma naturalmente amorosa e afetuosa. Se, por um lado, continua-se exigindo que a mulher seja amável no trato com as crianças, por outro lado, agora é necessário que ela esteja alegre e brinque.

Essa norma também se expande, ainda que nuances próprias, ao pai. Em Quando o amor é cruel, observamos essa norma no encerramento, quando o pai completa a carta do filho em seus últimos momentos, dizendo que são amigos. Em Mary Poppins, observamos que a versão das crianças apontada no início, de que o problema não são elas nem as babás, mas o pai, que não ajuda a fazer pipas, se impõe como a versão estruturante da narrativa pelo efeito de fechamento, da família reorganizada sem a necessidade da babá e com o pai brincando de pipa com os filhos. Porém, se a vida pública da mãe e sua militância como sufragista é interrompida com o gesto de doação da faixa sufragista, uma vez que não faz parte da construção da harmonia do lar, a vida pública do pai é retomada ao final quando ele é recontratado. A alegria e a brincadeira aparecem como enunciados que moldam a norma do comportamento dos pais em relação aos filhos, mas apenas a individualidade do pai é garantida. A mãe, ao contrário, deve renunciar às suas lutas políticas e à sua individualidade para cuidar pessoalmente das crianças.

O pai ignora as demandas das crianças e rasga o papel escrito por elas. Almirante Boom anuncia uma mudança de ventos e, voando, chega Mary Poppins. Ao contrário do narrador, que apresentava a casa como "residência de George Banks", Mary Poppins se endereça ao Sr. Banks colocando as crianças como referência: “É o pai de Jane e Michael 
Banks?" Depois, se nega a apresentar referências, "é uma ideia muito antiquada" e segue direto para as qualificações:

\footnotetext{
Mary Poppins - "Um: uma alegre disposição". Nunca me zango. "Dois: rosto corado". Obviamente. "Três: Fazer brincadeiras, todas". As crianças adorarão as minhas brincadeiras.

Sr. Banks - Onde conseguiu o papel? Pensei tê-lo rasgado.

Mary Poppins - Com licença. "Quatro: Deve ser amável". Sou amável, porém muito firme.
}

No primeiro contato com as crianças, Mary Poppins pega uma fita métrica de sua bolsa e mede as crianças. A fita, porém, em vez de apresentar a medição da altura, apresenta Michael como "extremamente teimoso e desconfiado" e Jane como alguém que "está sempre rindo, não gosta de guardar nada". Por fim, ainda deixam que ela seja medida pela mesma fita que classifica Mary Poppins como "praticamente perfeita em quase tudo".

Essa é a única cena em que cada uma das crianças é tratada de forma diferente, como um indivíduo com personalidade própria. No restante do filme, são tratados no plural, de forma que têm uma individualidade como crianças em relação aos pais adultos, mas não são tão individualizados em suas características pessoais, ao contrário do que vemos em $O$ amor é cruel e em Incompreendido.

Nessa mesma cena da fita métrica, também se constrói Mary Poppins como o ideal de perfeição, ou quase. $\mathrm{O}$ enunciado de que ela é quase perfeita será explicado, posteriormente, pelo fato dela não ser famíla. Ela é a norma, mas não é mãe nem o pai e essa família já tem mãe e pai. Ela terá, portanto, uma função apenas reestruturante, sem ser assimilada ao núcleo familiar.

E assim se constrói o comportamento de Mary Poppins durante todo o filme: amável, porém firme. Ela faz as tarefas do jeito dela e não da forma das crianças, porém sempre de um modo que as crianças não se sintam controladas, mas se interessem, fiquem curiosas. A cena seguinte talvez seja a que explicita essa construção:

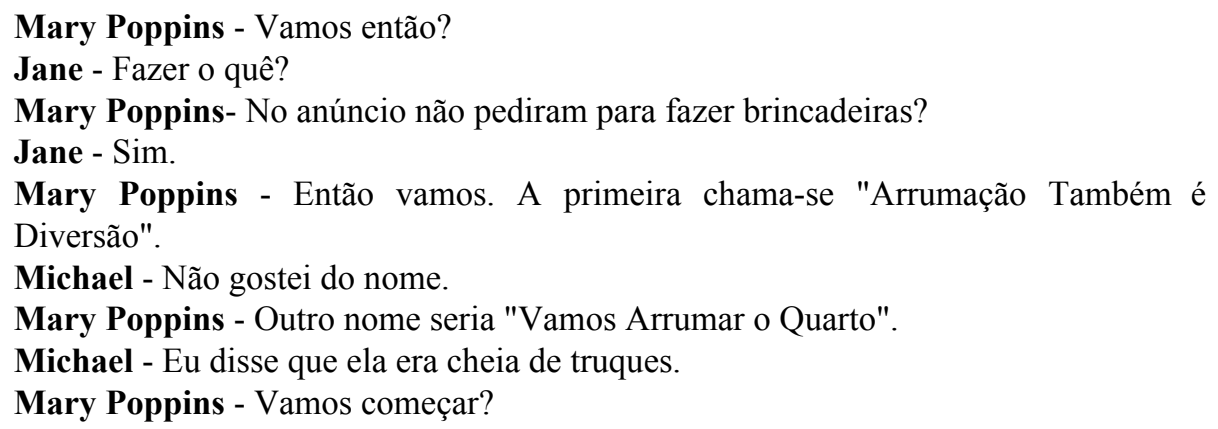




\begin{abstract}
Jane - É um jogo, não é, Mary Poppins?
Mary Poppins - Bem, depende de como o vê. Em toda tarefa a ser feita há um elemento de diversão. Encontre a diversão e pronto! A tarefa vira brincadeira. [Continua como uma canção]. Toda tarefa. Fica muito fácil. Uma farra, uma alegria. É fácil de se ver. Que uma colher de açúcar ajuda o remédio a descer. O remédio a descer. O remédio a descer. Que uma colher de açúcar. Ajuda o remédio a descer. Agora será um prazer. Um pássaro montando seu ninho não tem tempo de descansar. Juntado seus galhinhos, embora em seu trabalho confiante, sempre canta alegremente. Ele sabe que uma canção ajuda tudo num instante. Que uma colher de açúcar ajuda o remédio a descer. O remédio a descer. O remédio a descer.
\end{abstract}

Os três arrumam o quarto cantando e de forma mágica os objetos vão se encaminhando sozinhos para seus lugares. Ela impôs a tarefa, o momento e a forma de realizá-la, mas as crianças fazem tudo alegremente. Tão contentes que, ao final Michael diz: "Eu não quero sair. Quero arrumar o quarto novamente." As músicas e esse elemento de curiosidade e interesse que ela desperta, como se constrói discursivamente por meio da música, são apresentados como uma colher de açúcar, um elemento de diversão que transforma a tarefa árdua em "uma farra, uma alegria".

A brincadeira, esse elemento que transforma a tarefa em prazer, é uma forma de governo. Pela introdução desse elemento, as crianças agem de acordo com o plano de Mary Poppins. O filme apresenta essa forma de governo, em oposição ao modo do pai, como sendo mais eficiente. $\mathrm{O}$ filme nos ensina que a estratégia de Mary Poppins, de fazer com que as crianças realizem suas tarefas voluntariamente, é uma forma mais eficiente de governo das crianças. Assim, o filme pode ser visto em sua dimensão pedagógica como um filme que ensina os pais a forma de se relacionar com os próprios filhos. Certamente o filme não é o único nem pioneiro a construir esse discurso, mas se insere em uma ordem discursiva que compõe esse dispositivo de governo da conduta das famílias.

Diana e Mario Corso em seu A psicanálise da terra do nunca escrevem:

Convém notar que ao seu comando elas sempre obedecem, e aqui não usa nenhuma magia, apenas ela propõe formas que levam em conta as peculiaridades da infância. Jane e Michael faziam de tudo para serem escutados pelos seus pais, eles não eram particularmente monstruosos como os adultos a seu redor acreditavam, eram apenas crianças. (CORSO, 2011)

A passagem mostra que a construção das crianças como incompreendidas, também em Mary Poppins, como em Incompreendido, está relacionada à falta de escuta e à percepção equivocada de infância resultante desta falta. Os psicanalistas chamam a atenção para a existência de peculiaridades próprias da infância, que em grande medida, tomam como um 
pressuposto. Por conta das diferentes abordagens metodológicas e dos objetivos diversos ao nos debruçarmos sobre esses filmes, suspendemos tanto quanto possível a ideia pré-concebida de que exista algo particular na infância, para observar exatamente a construção discursiva dessas peculiaridades.

Se, por um lado, há uma continuidade significativa entre Incompreendido, de 1869, e O amor é cruel e Mary Poppins, da década de 1960, no que diz respeito à construção da falta de diálogo e de escuta como causas da percepção equivocada que produziria a criança como incompreendida; por outro lado, nos filmes da década de 1960, essa escuta já não é apresentada como uma predisposição natural da mãe. A questão central se desloca do problema deixar o filho correr riscos ou produzir um "mosca-morta" para a questão do prazer de realizar as tarefas brincando. Se em Incompreendido, o que dava prazer ao protagonista era o movimento, aqui, o que traz prazer é uma conversão do olhar, que pode ser induzida pelo adulto, transformando as tarefas em brincadeiras.

Nessa visão, contudo, a vida pública da mãe é claramente excludente da sua função materna. Constrói-se uma demanda das crianças que querem a figura da mãe dentro de seu mundo. De acordo com Diana e Mário Corso, operando com sua lógica mágica de pensamento, a Disney faz eco a essa demanda. (CORSO, 2011)

\footnotetext{
Não acreditamos que o sucesso do filme deva-se a qualquer postura patriarcal, apenas fica demarcado um contraponto entre a mãe e a cidadã. A título de curiosidade, no filme não há sequer um diálogo entre a mãe e a babá, esta última sempre se dirige exclusivamente ao pai das crianças. Provavelmente porque a mãe e a babá são faces da mesma figura feminina, a primeira é oficialmente submissa e secretamente revolucionária, enquanto Poppins é o inverso disso, francamente desobediente, mas devota à causa de aproximar os filhos de seu pai. (CORSO, 2011)
}

Novamente, apesar das diferentes abordagens, a análise de Corso nos permite colocar em questão algo interessante ao observar a desobediência de Mary Poppins ao lado da desobediência de Sra. Banks. Mary Poppins é construída como essa figura francamente desobediente em oposição à figura de Sra. Banks, que se preocuparia demais com as causas públicas e seria mais submissa no lar. Há outros elementos presentes. Mary Poppins é uma mulher que circula livremente por londres entre os trabalhadores, de quem é amiga. Ela é construída como uma mulher da classe trabalhadora, mas que carrega todas as características exigidas pela burguesia, do rosto corado à forma de se portar e se vestir. Seus laços com os trabalhadores indicam um pertencimento ao grupo, mas são laços afetivos, uma vez que ela 
não mora em lugar algum e chega voando à casa dos Banks. Ainda que seja possível pensar nas duas formas de desobediência como complementares na luta pelas transformações sociais do papel da mulher na sociedade, o filme constrói esses dois lugares como opostos e privilegia o modo de ação de Mary Poppins. No filme, a desobediência doméstica é justificada, enquanto a desobediência pública é vista como um obstáculo à harmonia familiar. A desobediência doméstica, porém, só é justificada como um meio para um fim, que é a reestruturação do lar, controlando os excessos do marido e restaurando os papéis socialmente construídos para cada gênero dentro de novos limites.

O espaço público é construído como um ambiente sem conflitos, de tal forma de Mary Poppins circula livremente sem restrições, sem assédio, sendo respeitada por todos os homens que encontra e com os quais interage sempre de forma tranquila como alguém plenamente aceita, o que seria uma utopia independente da época que pretendesse retratar. Numa Londres assim, bastaria combater o reinado masculino do lar. A luta política da sufragista é construída de forma não apenas ridicularizada mas também como desnecessária, como um falso problema.

Anne McLeer escreve, em seu artigo Practical Perfection? The Nanny Negotiates Gender, Class and Family Contradictions in 1960s Popular Culture (2002), que Mary Poppins reposiciona o pai como líder da família, ensinando-o a ser mais amigável. O papel da babá seria, de acordo com McLeer, o de restaurar a harmonia familiar, modernizando as relações entre pais e filhos de acordo com os conselhos dos especialistas da época, mas mantendo sua posição como chefe da família. Betty Friedan, em seu A Mística Feminina, nos lembra McLeer, chamava as mulheres a ocuparem os espaço públicos. Mary Poppins, assim como A Noviça Rebelde, afirma, apelavam, ao contrário, para que as mulheres retornassem à esfera doméstica e reorganizassem suas famílias. (MCLEER, 2002)

Ao final, a babá Mary Poppins vai embora voando e o pai prepara uma pipa para empinar com os filhos, retomando o objeto apresentado no começo da narrativa como a causa da discórdia (foi correndo atrás da pipa que as crianças se perderam na rua, levando a babá a pedir demissão). O efeito de fechamento (BORDWELL, 2005) com a construção uma nova harmonia é reforçado ainda com o gesto final da mãe, que abre mão da faixa do movimento sufragista para construir esse elemento de união em torno da família: "Uma boa pipa precisa de uma boa cauda." 


\subsection{A Noviça Rebelde}

O musical A Noviça Rebelde (The Sound of Music) conta a história de Maria, uma freira que não se adequa aos padrões do convento em que vive, em Salzburg, na Áustria, e é enviada para trabalhar como babá de sete crianças na residência do viúvo Barão von Trapp, que comanda a casa com disciplina militar. O Barão começava um relacionamento com a baronesa Elsa Schraeder, que tenta manipular a situação para garantir a efetivação do casamento com o Barão. Os esforços, porém, se revelam vãos, pois o capitão se apaixona por Maria, com quem se casa ao final.

O filme começa com a construção discursiva de Maria como uma freira-problema, com a Reverenda Madre conversando com outras freiras enquanto Maria está sumida. O mote da primeira canção é "Como resolver o problema que é Maria?”. As freiras argumentam em defesa ou não de Maria e a descrevem: "Ela trepa em árvores e rala o joelho. Sua roupa está rasgada. Ela dança a caminho da missa e assobia nas escadas", "Elas se atrasa para os sacramentos, mas a penitência é sincera", "É delicada, é maluca. Uma dor de cabeça. Ela é um anjo. É uma menina.”, “Uma tagarela. Um fogo-fátuo. Uma palhaça.”, "Maria me faz rir”, “Mas como fazê-la parar e obrigá-la a escutar?”. As definições constroem Maria, como uma mulher-criança, sincera, espontânea, divertida, porém incontrolável.

Na cena seguinte, a própria Maria, explicando-se à Reverenda Madre, afirma que não consegue parar de cantar e diz: "Não consigo evitar, onde quer que eu esteja. E pior: não consigo parar de dizer coisas. Tudo o que penso e sinto." Ao que a Reverenda responde: "Há quem chame isso de honestidade".

A música, fio condutor de todo o filme e presente inclusive no título original, é associada, pela fala de Maria, à espontaneidade, pureza e honestidade. Tudo decorre como se Maria fosse imaculada, não tivesse sido corrompida pela vida adulta, ela ainda sobe em árvores e canta. McLeer (2002, p. 87) sugere inclusive que a Maria seja construída à semelhança de Virgem Maria, remetendo a um ideal materno cristão de pureza, uma vez que a personagem, como na narrativa cristã, se casa e se torna mãe virgem.

Após estabelecer a imagem pura e pueril de Maria, o diálogo prossegue construindo a imagem das crianças como ingovernáveis. "Parece que ele tem dificuldades em manter uma governanta por lá”, alerta. Depois, já na residência, o Barão lhe informa que ela é a décima segunda governanta desde a morte da esposa. Assim como em O Amor é Cruel e Mary 
Poppins, a construção das crianças como problemas é realizada inicialmente por meio da troca constante das mulheres encarregadas.

Ao longo do filme, outros enunciados sobre a dificuldade de governar as crianças reforçam os primeiros. As crianças se apresentam a Maria como "incorrigível”, outro “impossível” e, logo em seguida tentam pregar peças em Maria.

Décima segunda governanta. “O que há de errado com as crianças?”, Maria pergunta. “As crianças não têm nada de errado. As governantas, sim. Não conseguiram manter a disciplina, sem a qual não se administra uma casa", responde o Barão. O problema não são as crianças, é a expectativa do Barão, que é apresentada de forma bastante caricatural. Ele passa as instruções à Maria, que incluem tomar os estudos inclusive nas férias, marchar e respeitar rigidamente o horário de dormir.

“Quando brincam?”, interrompe Maria. Já de saída, a trama está montada: o Barão, que chama os filhos com um apito e trata todos como soldados, quer garantir a harmonia da casa pelo rigor disciplinar, enquanto Maria é apresentada como aquela que ri, canta e brinca com as crianças, compreendendo-as em sua especificidade de crianças.

O primeiro pedido de Maria é que o Barão lhe forneça material para que ela costure roupas de brincar às crianças. Ele se nega. "Mas são crianças!”, reclama Maria. Assim, os dois enunciados se ligam: "são crianças", "precisam brincar". O brincar é apresentado como característica constitutiva da infância. O pai, ao negar o brincar, não estaria compreendendo a infância dos filhos. A construção das crianças como incompreendidas em A Noviça Rebelde, portanto, se relaciona com as travessuras e as trocas constantes de governantas, mas também com a interdição do brincar.

Uma vez que Maria cria um elo com as crianças permitindo que brinquem e estimulando-as a cantar, o que também era proibido, ela questiona as crianças sobre as travessuras: "Não entendo como crianças tão boas podem fazer essas travessuras". As crianças respondem: “Como vamos chamar a atenção do papai?”. Elas não são travessas por natureza, apenas agiriam assim, de acordo com o filme, porque o pai não lhes daria atenção.

Também em A Noviça Rebelde, a incompreensão dos filhos é construída como resultado de um erro de percepção do pai por conta de sua ausência e falta de escuta. O pai está sempre viajando: “Como pode viajar tanto?", "Crianças, irei à Viena amanhã de manhã." “De novo não, pai!”, “Da última vez que visitou a baronesa ficou um mês”. E quando está em 
casa, não está atento aos filhos, o que é, em grande parte construído por meio desse diálogo em forma de desabafo entre Maria e o capitão:

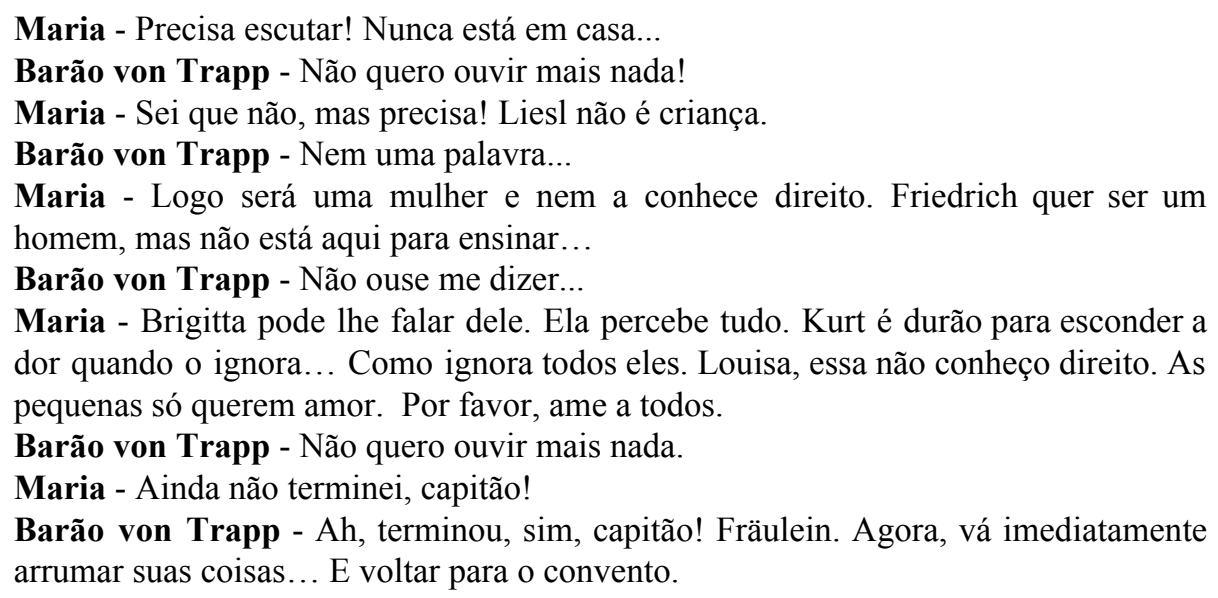

Ele ignora os filhos, porque os trataria como um capitão e não como um pai amoroso. Se consideramos o pedido de Maria, "Por favor, ame a todos", como um enunciado em relação com outros do filme, o "ame", aqui, será visto como um sinônimo de "não ignore", “esteja presente", "escute". O fato de que o Barão não realizaria isso porque trata todos como um capitão é reforçado com o ato falho de chamar Maria de "capitão".

Em, A Noviça Rebelde, os excessos disciplinares do Barão são explicados como forma de lidar com a morte da esposa: "Desde que o capitão perdeu a esposa, coitada... Ele dirige essa casa como um de seus navios. Apito, ordens. Não tem mais música, não se ri mais. Nada que o recorde dela. Nem os filhos.” Após o desabafo de Maria, quando o Barão a chama de Capitão, os dois são surpreendidos com uma música:

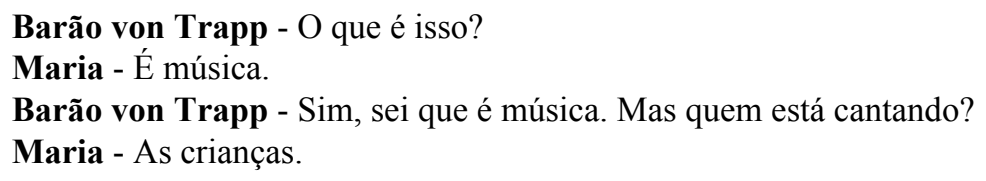

A música, que é construída desde o começo do filme, com a descrição de Maria no convento como aquela que canta porque é infantil e espontânea, aparece como a infância brotando novamente nas crianças. Maria teria resgatado a infância das crianças, incompreendidas pelo pai. O efeito é quase mágico. O pai, sensibilizado pela música, percebe a própria falha:

Barão von Trapp - Você tinha razão. Não conheço meus filhos. Maria - Ainda há tempo capitão. Eles querem se aproximar do senhor. 
Barão von Trapp - E você trouxe música de volta a essa casa. Eu tinha esquecido.

Maria reintroduz o respeito à espontaneidade e à pureza da infância no lar, mas algo ainda ameaça essa espontaneidade: a baronesa. Durante o filme, Elsa Schraeder é construída como uma mulher dissimulada, manipuladora, em oposição à figura de Maria. Para que a harmonia do lar e o cuidado das crianças possa ser mantido, esse modelo precisa ser retirado, substituído. Maria é convertida de governanta em esposa e mãe.

O casamento e o efeito de fechamento (BORDWELL, 2005) como happy ending da família agora em harmonia coroa Maria como o ideal de mulher e de mãe de $A$ Noviça Rebelde. A mãe ideal é espontânea, faz rir, é pura e devota às crianças. Essas características, ao contrário do livro Incompreendido, de 1869, não são consideradas naturais da mulher, mas são construídas como pré-requisitos para a criação dos filhos. A mulher deve ser meio criança, portanto, dependente. Essa relação é construída de forma mais direta no romance entre Liesl, a filha mais velha, de 16 anos, prestes a fazer 17, e Rolfe, o mensageiro de 18 anos, prestes a fazer 19:

\footnotetext{
Liesl - Tenho 16 anos! O que isso tem de criancinha?

Rolfe - Você espera, menina, num palco vazio, que o destino acenda as luzes. Sua vida, menina, é uma página em branco onde os homens desejarão escrever. Escrever... Você tem 16 anos, vai fazer 17. Menina, é hora de pensar. Melhor se cuidar, ser esperta e cuidadosa. Menina, está no limiar. Você tem 16 anos, vai fazer 17 , os rapazes vão se alinhar. Jovens ansiosos e malandros perigosos a vão querer cortejar. Você não tem preparação para o mundo dos homens enfrentar. Tímida, acanhada e com medo das coisas além do seu entendimento. Precisa de alguém mais velho e mais sábio, que lhe diga o que fazer. Eu tenho 17 anos, vou fazer 18. Eu cuido de você.

Liesl - Tenho 16 anos, vou fazer 17. Sei que sou ingênua. Os rapazes que conhecer podem coisas me dizer e logo vou acreditar. Tenho 16 anos, vou fazer 17, inocente como uma flor. Belos solteirões, bebedores bonitões, disso o que vou saber? Não tenho nenhuma preparação para o mundo dos homens enfrentar. Tímida, acanhada e com medo de coisas que não entendo, preciso de alguém mais velho e mais sábio, que me diga o que fazer. Você tem 17 anos, vai fazer 18, de você vou depender.
}

Se por um lado, o ideal da mulher-mãe é o de uma mulher pueril, pura, feliz e espontânea, por outro lado, essa mulher-criança é apresentada como alguém que não conhece os perigos do mundo e que precisa de alguém para cuidar dela. A mulher-criança é construída como uma mulher que depende de um homem. As características de uma boa mãe não são, como no livro Incompreendido, construídas como inatas. Dessa forma, a mãe não é insubstituível. O filme ensina que a função de mãe, no entanto, só poderia ser bem preenchida por mulheres de um determinado perfil de mulher-criança pura, feliz, brincalhona, 
compreensiva e dependente, que seria capaz de compreender as crianças e amenizar os excessos disciplinadores do pai, uma vez que ela também carrega em si parte das características dessas crianças.

\section{4. O discurso sobre a infância em Quando o Amor é Cruel, Mary Poppins e A Noviça}

\section{Rebelde}

Nos três filmes as crianças são construídas, logo no início, como ingovernáveis pela mesma estratégia: a troca constante de babás. Ao fazê-lo, os filmes indicam que a estratégia disciplinadora, do controle por ordens e interdições, precisa ser substituída.

O tio outsider do núcleo familiar restrito que divide o mesmo lar é responsável, em Quando o Amor é Cruel, por revelar o erro de percepção do pai sobre o próprio filho causado pela ausência de escuta e de diálogo. A babá outsider em Mary Poppins é responsável por revelar o erro de percepção do pai causado pela ausência e pelo olhar extremamente disciplinar, reestruturando a família em torno do pai transformado. A babá outsider em $A$ Noviça Rebelde é responsável por revelar o erro de percepção do pai sobre os filhos igualmente pela ausência e pela falta de escuta, mas é integrada ao núcleo em torno do pai transformado. Nos três casos, o outsider não é um especialista, mas apenas alguém que tem um olhar mais atento às crianças e que ousa desafiar a autoridade do pai, que é apresentado como equivocado. Não há nenhum discurso de especialista sobre as crianças.

Em nenhum dos três filmes a babá participa da nova harmonia familiar como babá: em Quando o Amor é Cruel, porque o filho morre e não há a constituição de uma nova harmonia, mas a indicação de um suposto reencontro do filho com a mãe pela morte; em Mary Poppins a babá vai embora voando após cumprir o papel de reestruturar a família; em $A$ Noviça Rebelde a babá é incorporada ao núcleo familiar pelo casamento, convertendo-se em mãe.

Nos três filmes a mãe é ausente. Em Quando o Amor é Cruel e em A Noviça Rebelde porque está morta, em Mary Poppins, porque está dedicada à causa pública das sufragistas. Em todos os casos, o pai é apresentado como incapaz de, nessa ausência da mãe, criar as crianças de forma satisfatória. Nos três filmes a questão central da incompreensão gira em 
torno da figura do pai e não da mãe e é construída como consequência da ausência e da falta de diálogo. Em Mary Poppins e em A Noviça Rebelde, isso é agravado pelo excesso disciplinador do pai, que só é remediado quando aparece uma figura feminina com características maternais para endireitá-lo.

A imitação deixa de ser o elemento que leva ao comportamento visto como travesso das crianças. O comportamento ingovernável das crianças é construído nos três filmes como resposta ao excessos disciplinares das babás e do pai e a solução seria o bom desempenho, por uma mulher adulta, do papel de mãe, reequilibrando a família, controlando o pai e estimulando os filhos pela sugestão e pela brincadeira e não pela imposição. As características da boa mãe são, nos três filmes: sorrir, incentivar em vez de punir, e brincar.

Conjuntamente, portanto, os filmes ensinam que as crianças são incompreendidas porque o pai não está presente e não escuta. Apesar disso, a solução construída para essa incompreensão aponta mais para o comportamento da mãe do que para o comportamento do pai. Se, por um lado, os filmes ensinam que o pai deveria conseguir controlar sua tendência autoritária e estar presente para escutar os filhos e compreender as especificidades da infância e da adolescência, por outro lado, ensinam que a regulação do comportamento do pai é função privilegiada da mulher-mãe. A mãe não é construída como dotada de habilidades naturais apenas por ser mãe e, portanto, torna-se um papel social que não precisaria mais ser necessariamente ocupado pela mãe biológica. Porém, nesse discurso, para que desempenhe esse papel de forma satisfatória, a mãe deve ser devotada aos filhos de tal forma que esteja feliz nesta função, deixando outras funções públicas e se submetendo à autoridade do marido, ao mesmo tempo que a controla quando ela se direciona aos filhos de modo impositivo. A mãe, para exercer adequadamente sua função, deve, então, abrir mão de sua individualidade, uma vez que deve ser totalmente devotada à vida familiar. O pai continua tendo direito à individualidade, mas deve regular seus projetos de modo que não seja ausente. Não há discurso de especialistas sobre a família. A incompreensão do pai é apontada, nos três casos, pela figura de outsider próximo da família a tal ponto que seja capaz de enunciar que a indisciplina é uma resposta ao comportamento autoritário e que os filhos podem ser governados se houver uma mudança de estratégia. A imitação não faz parte da dinâmica, mas tampouco uma suposta essência da criança. A alteração de estratégia seria a substituição de uma educação impositiva por uma mais compreensiva, que estimule e divirta ao apresentar as 
tarefas necessárias de forma mais divertida, um governo fundamentado na compreensão e empatia pelas crianças. 


\section{Essência individual incompreendida da criança, família que aceita}

Passamos agora para uma seleção de filmes contemporâneos, produzidos entre 1997 e 2016: Billy Elliot, de Stephen Daldry (2001); Minha Vida em Cor-de-Rosa, de Alain Berliner (1997); A Família Bélier, de Eric Lartigau (2014); Moana: um mar de aventuras, de John Musker e Ron Clements (2016); O Grande Dia, de Pascal Plisson (2015); Pequena Miss Sunshine, de Jonathan Dayton (2006); e, por fim, Incompreendida, de Asia Argento (2014), uma releitura de Quando o Amor é Cruel (1966).

\subsection{Billy Elliot}

Em Billy Elliot (DALDRY, 2000) acompanhamos a vida da família Elliot na pequena cidade de Durham, interior da Inglaterra, no ano de 1984. A família é composta pelo pai Jackie, os dois filhos Tony e Billy e a avó Nan, que moram juntos em uma pequena casa operária. Enquanto o pai e o primogênito trabalham na mina de carvão e participam ativamente das greves, Billy é responsável por cuidar da avó, que tem problemas de memória e se perde sozinha. A trama gira em torno do fascínio de Billy pelo balé e da relação da família de mineiros com essa paixão do filho de 11 anos. Neste filme, o problema central é, a princípio, uma questão de identidade e que coloca em questão estereótipos de gênero.

O filme começa com Billy colocando um disco e dançando em sua cama. O menino prepara o café da manhã da avó, mas ela saiu sozinha de casa e ele sai para encontrá-la. Em seguida, conhecemos Tony, o irmão mais velho de Billy. Tony xinga Billy por mexer em seus discos, o caçula critica o irmão por fumar: "Se papai soubesse que você fuma essa coisa, ficaria furioso." (DALDRY, 2000). Logo de saída já se estabelece que a relação entre o pai e os filhos é de cuidado que pode se manifestar pela raiva. O primogênito e o pai se arrumam para ir a um piquete. Tony grita ao pai e a Billy enquanto se prepara para sair:

Tony - Anda, pai, vamos nos atrasar. Todo mundo vai estar nesse piquete hoje. Arrumou nosso quarto? Pai?

Pai - Não sobrou muito mais carvão.

Tony - Ótimo. Estaremos escavando de novo mês que vem.

(DALDRY, 2000) 
$\mathrm{Na}$ família Elliot, as individualidades do pai e do filho mais velho estão atreladas a uma batalha por sobrevivência, o que, na construção narrativa, passa pela luta sindical por melhores condições de trabalho nas minas de carvão. O bairro em que moram e o local onde trabalham é, durante o filme, constantemente ocupado por policiais. A televisão ligada na casa, em uma cena, insere a narrativa de luta do pai e do irmão nas minas no contexto da luta por direitos trabalhistas na Inglaterra liberal de Margaret Thatcher:

No discurso de ontem aos conservadores, a Primeira Ministra Margaret Thatcher se referiu aos grevistas do Sindicato Nacional de Mineradores como "Inimigos Internos". O discurso aconteceu depois de vários meses de violentos confrontos entre policiais e mineradores em greve...(DALDRY, 2000)

Billy, por influência do pai, ex-boxeador, vai para a aula de boxe no clube para meninos. O menino acredita, a princípio, que é bom, que tem potencial para o box e olha para a luta com certa reverência:

EVERINGTON, CLUBE PARA MENINOS.

Billy - Tem certeza que não quer vir?

Michael - Eu, não. São um monte de babacas.

Billy - Não são, não.

Michael - É uma merda ficar socando gente. Não sei porque faz isso.

Billy - Sou bom nisso.

Michael - Até parece. Olhe só essas luvas, são do arco da velha.

Billy - Eram do meu pai.

Michael - Por isso mesmo.

(DALDRY, 2000)

Durante a luta, porém, logo fica claro que ele não tem futuro no boxe.

Treinador - De novo, não. Isso é um combate homem-homem, não uma dança de salão. O que está fazendo?

Pai - Acerte-o!

Treinador - Ele está de sacanagem. Vai fundo, mete pancada. Ele tá parecendo uma garotinha. Billy! Acerte-o! Meu Deus, Billy Elliot. Você é uma vergonha para essas luvas, pro seu pai, e para as tradições dessa academia de boxe.

(DALDRY, 2000)

As falas do treinador, comparando o menino com um dançarino, já apontam para um suposto dom da dança a ser descoberto. Também, ao dizer que é um "combate homem-homem" e que Billy está "parecendo uma garotinha", o treinador posiciona o lutar e 
o dançar em relação a diferentes construções sociais de identidades de gênero. Por fim, ainda compara o filho ao pai, como uma desonra.

Exatamente por conta da greve dos mineiros, como um paradoxo das consequências, Billy se aproxima do balé. O treinador avisa que "O andar de baixo está sendo usado como refeitório dos grevistas, então deixarei a sra. Wilkinson usar os fundos do ginásio de boxe para suas aulas de balé. Então nada de assanhamentos, entenderam?” (DALDRY, 2000). Billy fica devendo 50 pence pela aula e deve pagar à Sra. Wilkinson durante a semana. A aula está acontecendo quando Billy chega e fica observando atentamente. A professora, percebendo o envolvimento do garoto, convida: "Por que não vem dançar?". Se tirar o foco das meninas, continua a aula e convida Billy: "Qual é o seu tamanho?", "Vamos lá, eu lhe desafio.” Ao final da aula, Sra. Wilkinson cobra o garoto pela aula:

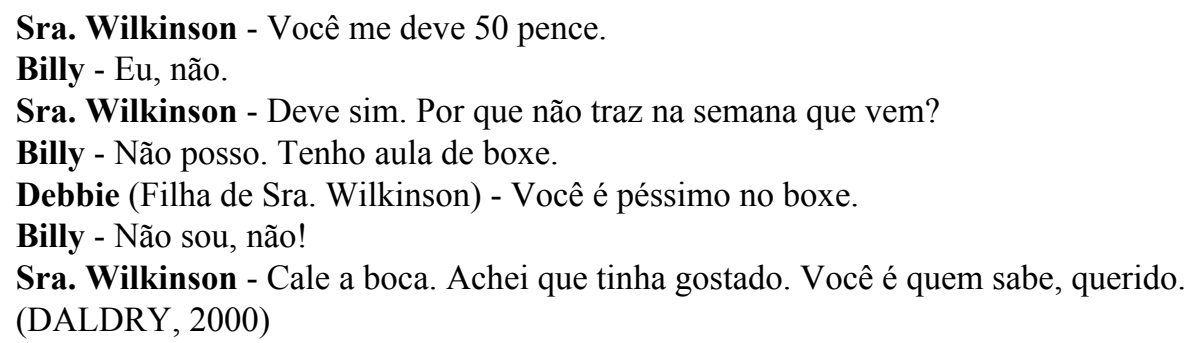

Não sabemos se a professora o faz pelo dinheiro ou não, mas ela não apela a nenhuma outra relação além do gosto. “Achei que tinha gostado" é apresentado como motivo suficiente para continuar o curso, sem o peso das luvas, do legado ou das expectativas.

A cena seguinte é do garoto e da avó, que ficava em grande parte sob seus cuidados, visitando o túmulo da mãe de Billy, enquanto conversam. A avó comenta que a mãe de Billy gostava de dança: "Ele era o preferido da sua mãe, o Fred Astaire. A gente assistia a ele no Palace Picture House, e depois dançávamos na sala que nem malucas. Uma maravilha.”. Ela não se posiciona nem aconselha Billy diretamente, mas compartilha essas lembranças e um sonho antigo de ser bailarina: "Eles diziam que eu podia ter sido bailarina profissional".

A tensão entre ser homossexual e dançar balé aparece em alguns momentos. Entre as cenas mais marcantes sobre a questão, porém, há uma inversão entre quem profere cada enunciado. No diálogo entre Billy e Debbie, a filha da professora, é Billy que ainda está 
desconfortável com a situação e questiona Debbie sobre o fato de só homens homossexuais fazerem balé.

Debbie - Muitos meninos estudam balé.

Billy - Ah, é? Que meninos?

Debbie - Nenhum daqui, mas muitos homens fazem.

Billy - Bichas.

Debbie - Nem sempre.

Billy - Quem, por exemplo?

Debbie - Wayne Sleep. Ele não é bicha. Ele tem corpo de atleta.

Billy - Aposto que não vence o Daley Thompson. Talvez não numa corrida, mas na força. Por que não vem amanhã? Só olhar.

Billy - Não posso. Tenho que ir pra aula de boxe, não é?

Debbie - Você é quem sabe.

(DALDRY, 2000)

Para poder ir ao balé sem contar ao pai e ao irmão, Billy diz que continua frequentando as aulas de boxe e usa os 50 pences para pagar Sra. Wilkinson. A estratégia funciona até o momento em que o treinador pergunta ao pai sobre a ausência de Billy nos treinos. Quando conversa com o pai, na cena em que se confrontam sobre as aulas de balé, Billy incorpora os argumentos de Debbie à sua própria fala e já defende com convicção que não existe uma relação necessária entre a dança e a orientação sexual dos dançarinos.

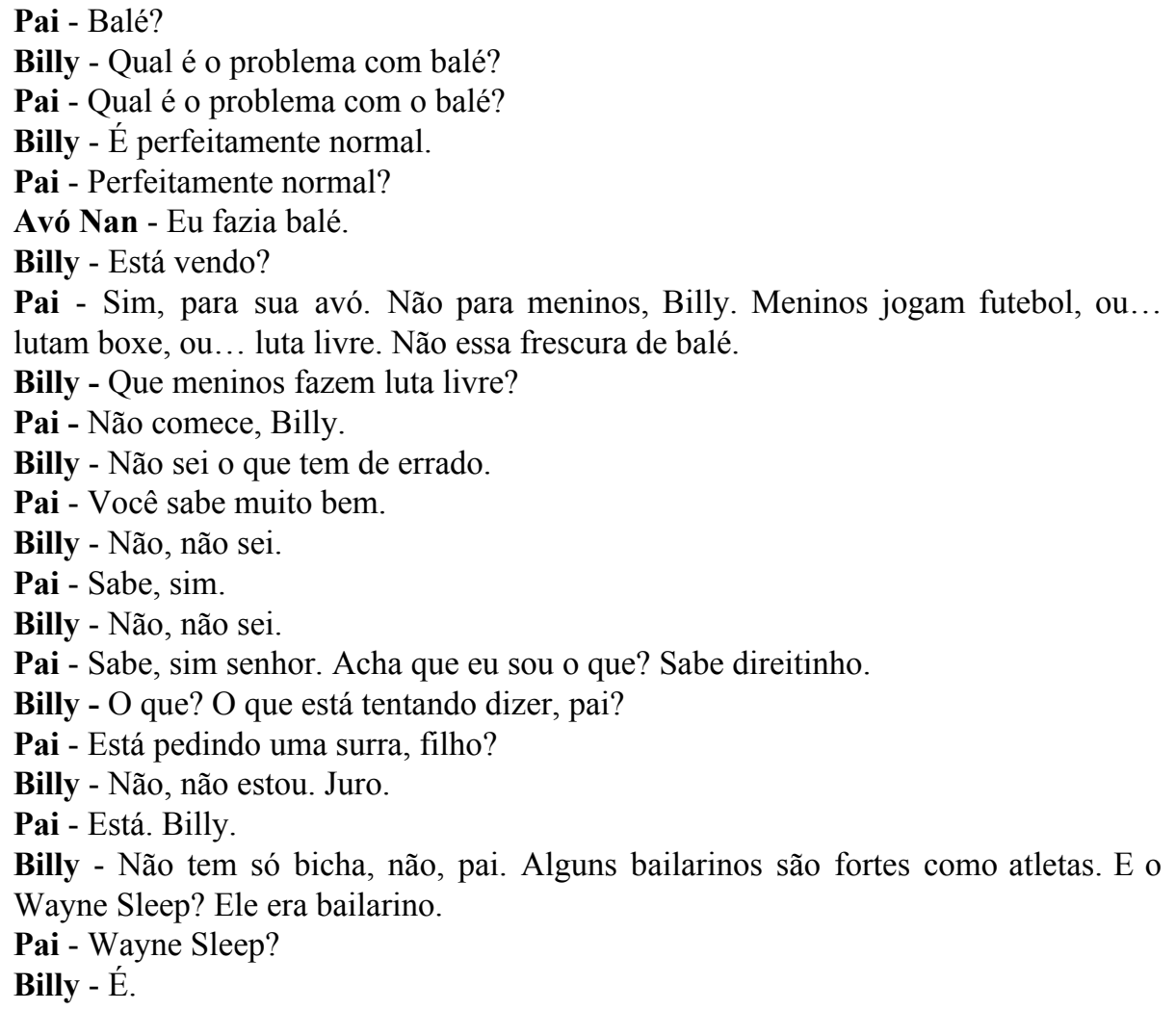


Pai - Ouça, filho, de agora em diante, pode esquecer essa coisa de balé. Pode esquecer o boxe também. Eu me esfalfo por estes 50 pence e você... De agora em diante você fica aqui cuidando de sua avó. Entendeu?

Billy - Muito bem.

Avó Nan - Eles diziam que eu podia ter sido bailarina profissional.

Pai - Dá pra calar a boca?

Billy - Eu te odeio! Você é um canalha! Me larga!

(DALDRY, 2000)

O personagem de Michael, amigo de Billy, também age na narrativa de forma a afastar qualquer relação entre a paixão de Billy pela dança de outras questões relacionadas à identidade de gênero ou à sexualidade. Michael gosta de Billy e de se vestir com as roupas da mãe. Michael questiona Billy tanto sobre a vontade de vestir saias e vestidos quanto sobre a vontade de ficarem juntos e se Billy quer ver seu bumbum. Billy rejeita as duas ofertas e continua conversando com Michael sobre as questões que o afligem relacionadas à vontade de dançar balé contra a vontade do pai. A amizade segue inabalável.

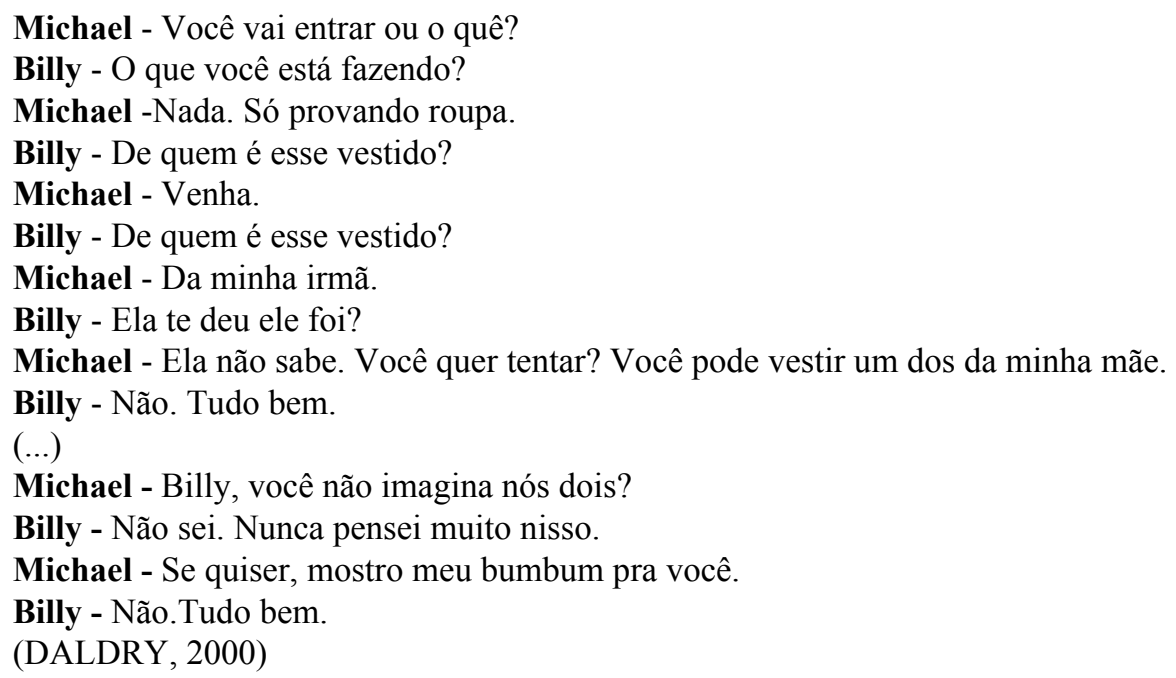

Michael chega a questionar Billy, por que, então, ele vai às aulas de balé toda semana:

Michael - Vai ao balé toda semana?

Billy - Vou, mas não fica falando.

Michael - Por que precisa ir à aula?

Billy - O que acha? Para melhorar, seu burro.

(DALDRY, 2000)

As possíveis relações entre o gosto pela dança e a orientação sexual ou identidade de gênero de Billy são descartadas pela própria narrativa, ao contrário do que supôs, por 
exemplo o crítico de cinema Inácio Araújo ao escrever que Billy Elliot "opera uma troca de preconceitos: aceita-se a homossexualidade como opção sexual, mas ao mesmo tempo projeta o operário no poço profundo da insensibilidade" (ARAÚJO, 2001). Ainda que não concordemos com a análise realizada por Araújo, não deixa de ser interessante notar que um filme sobre um menino que quer dançar balé tenha sido tratado por parte da crítica como um filme sobre homossexualidade. Ao contrário do colega de redação, Marcelo Coelho escreveu na Folha de S.Paulo que "Billy gosta de dançar, mas não faz um gênero de vítima e não parece ter uma inclinação homossexual. Nem sequer se questiona muito sobre sua sexualidade; é um menino apenas." (COELHO, 2001). Ao negar o envolvimento tanto com Michael quanto com Debbie, a orientação sexual de Billy permanece desconhecida do espectador. O balé é apresentado como um fim em si mesmo. Uma paixão, um potencial, um dom que pode ser desenvolvido.

Após qualquer outra relação entre a vontade de dançar balé e a sexualidade ou a identidade de gênero de Billy ser descartada, chegamos à cena em que esse dom é finalmente revelado, enunciado pela professora de dança, Sra. Wilkinson. Billy já enfrentou o pai e está disposto a abrir mão de tudo. Ele vai à casa da professora para avisar sobre a desistência. Revela-se, então, que a professora tinha o projeto de que Billy prestasse o concurso para a Academia Real de Balé de Londres, pois via nele um incrível potencial:

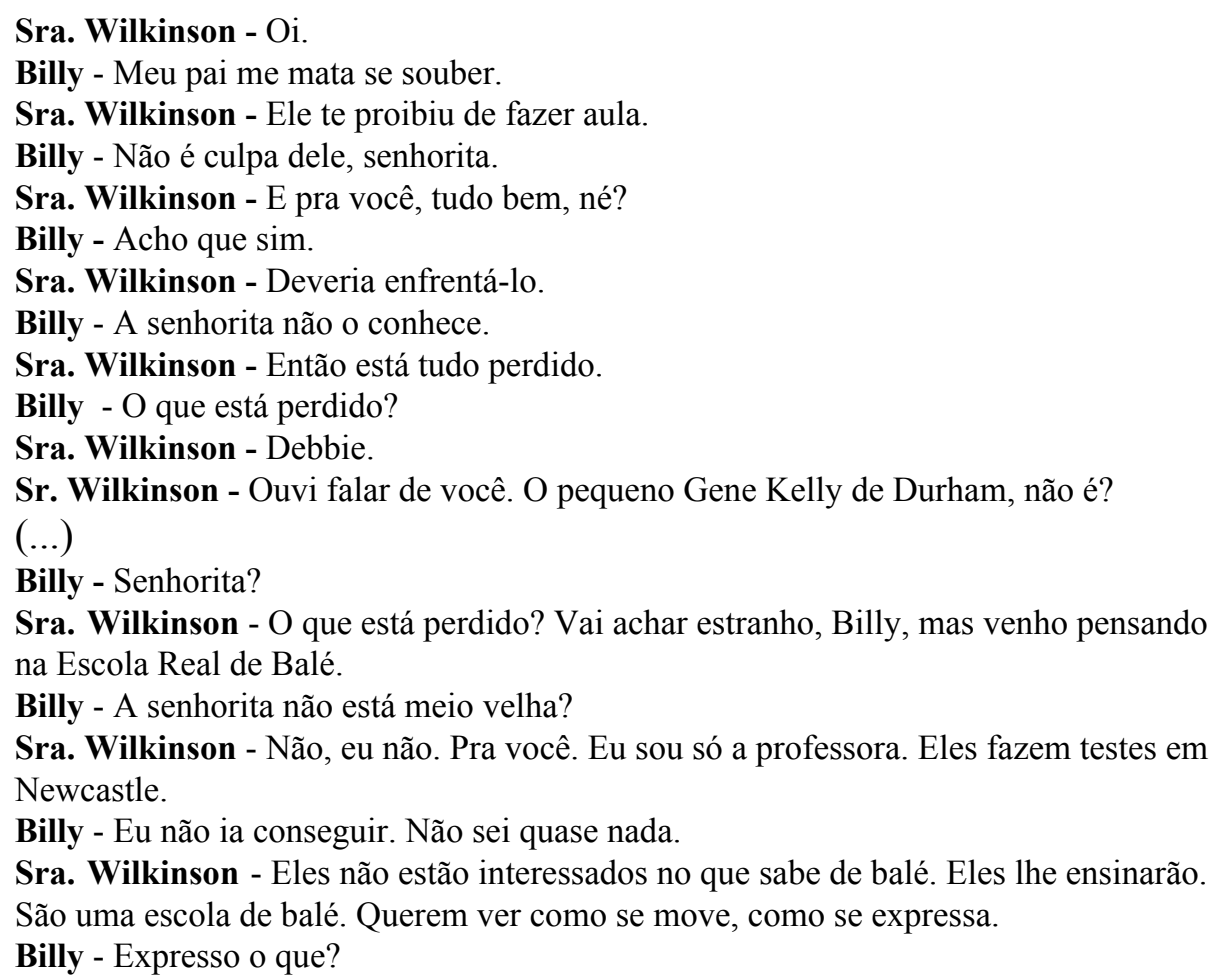


Sra. Wilkinson - Você é bom o bastante pra tentar. Mas teríamos que trabalhar muito duro.

Billy - Mas fui proibido.

Sra. Wilkinson - Eu podia conversar com ele.

Billy - Não, senhorita.

Sra. Wilkinson - Poderia lhe ensinar sozinho.

Billy - Não temos como pagar.

Sra. Wilkinson - Não é pelo dinheiro, Billy.

Billy - Mas e o meu pai?

Sra. Wilkinson - Ele não precisa saber.

Billy - Mas e o boxe?

Sra. Wilkinson - Se quer ficar de bobeira com seus amigos, então tudo bem.

Billy - Tá bem, não precisa se descabelar!

Sra. Wilkinson - Me descabelar?

Billy - Então vai ser uma aula particular?

Sra. Wilkinson - Só eu e você.

Billy - Não está dando em cima de mim, né?

Sra. Wilkinson - Não, Billy, é engraçado, mas não estou. Agora cai fora.

Billy - Cai fora você.

Sra. Wilkinson - Até segunda.

(DALDRY, 2000)

Em Billy Elliot, não é o pai que diz o que é ou não vocação de Billy, como era o caso de Humphrey no livro Misunderstood (1869). A vocação também deixa de ocupar um lugar secundário na trama para se tornar o elemento central em torno no qual se constrói a ideia de incompreensão.

Após começar a treinar individualmente com Sra. Wilkinson, Billy mostra à professora uma carta que a mãe lhe deixara antes de morrer:

Querido Billy, sei que devo ser uma lembrança distante para você... o que provavelmente é uma boa coisa. Já terá se passado um longo tempo, e eu terei perdido ver você crescer, ver você chorar, rir... gritar. Terei perdido me zangar com você. Mas saiba que eu estava sempre aí.. com você em tudo. Com você em tudo. E sempre estarei. E tenho orgulho de ter conhecido você, e tenho orgulho de que tenha sido meu. Seja sempre você mesmo. Te amarei para sempre. Mamãe. (DALDRY, 2000)

A carta fala mais da mãe do que de Billy, fala de tudo que a mãe perderá, sabendo seu destino, de como ama Billy, tem orgulho dele e de alguma forma acompanha sua vida. O único momento em que a carta se dirige para Billy a fim de deixar-lhe algum conselho é no final, quando a mãe escreve "seja sempre você mesmo". 
Figura 1 - Cena de Billy Elliot em que se lê a carta da falecida mãe de Billy: "Seja você mesmo".

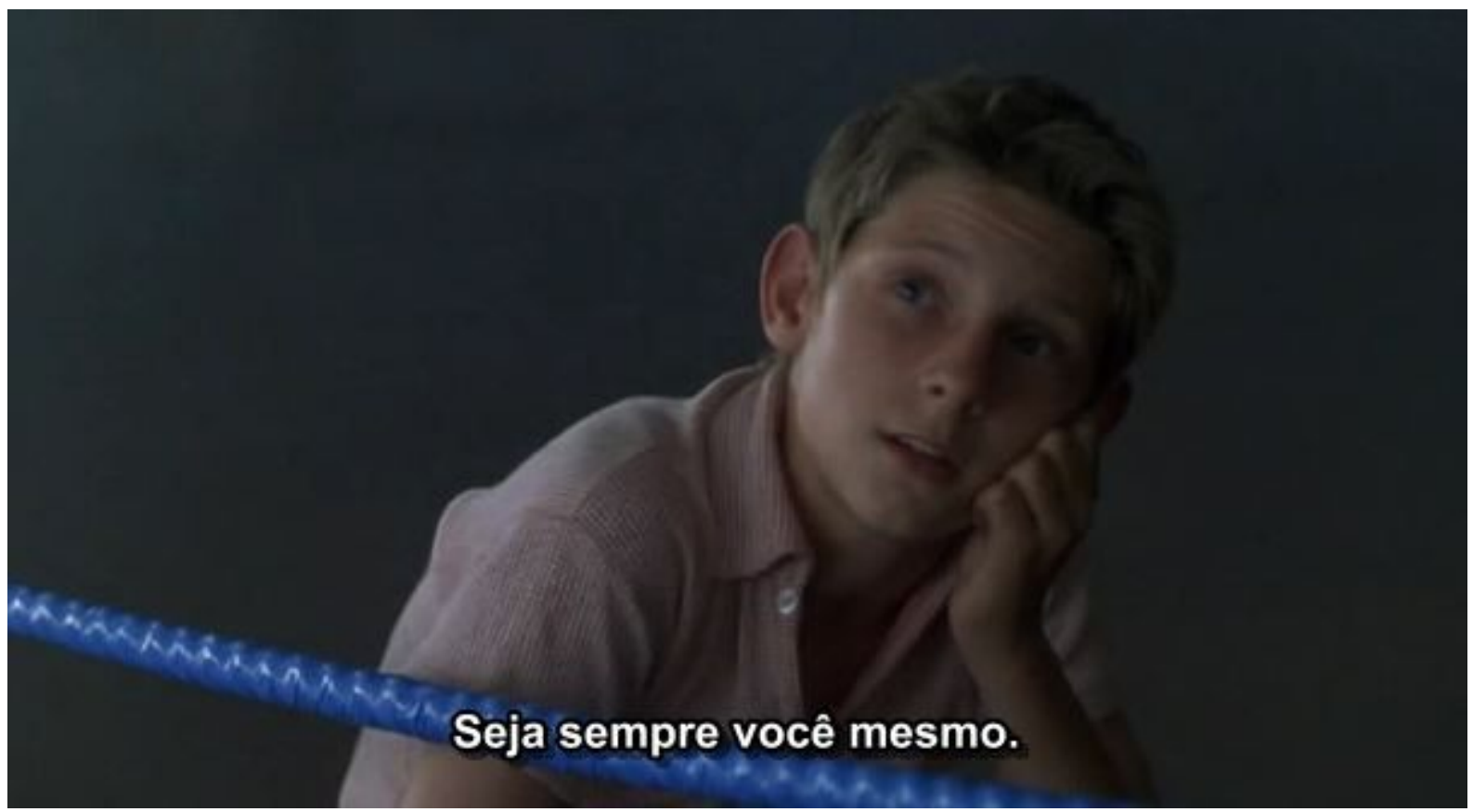

Fonte: print screen do filme Billy Elliot.

Billy mostra a carta para Sra. Wilkinson, a professora de balé. Ela reage dizendo: "Ela deve ter sido uma mulher muito especial.". Billy responde: "Não, ela era só a minha mãe." Constrói-se, desta forma, a imagem da mãe falecida como uma mãe normal, "era só a minha mãe". Suas características são exaltadas não por aquilo que poderiam ter de único, de exclusivo, mas por aquilo que carregam de comum. A cena, somada à leitura da carta, nos ensina que uma mãe normal deve amar o filho, acompanhá-lo de perto e "ensiná-lo a ser sempre ele mesmo". Em relação ao livro de 1869 e aos filmes da década de 1960 analisados nos capítulos anteriores, a descontinuidade, a novidade, está justamente no último enunciado: "os pais devem aceitar os filhos como eles são". Tanto o enunciado de que Billy possui um dom, como o de que os pais devem aceitar os filhos como eles são, ainda serão reforçados em outras cenas centrais para o desenvolvimento da trama.

O pai de Billy encontra o garoto novamente dançando no ginásio. O filho se recusa a parar e dança energicamente na frente do pai. O pai vira as costas, manda o garoto ir para casa e, mesmo sendo o dia do Natal, vai direto à casa de Sra. Wilkinson perguntar quanto tudo isso custaria. Decide apoiar o filho, mas o teste lhe custará 2 mil, dinheiro difícil para a 
situação da família. A cena seguinte é do pai furando a greve para trabalhar. O filho mais velho, Tony, enfrenta o pai:

Tony - Pai! Que diabos está fazendo?! Pai, não pode voltar atrás! Não agora!

Pai - Olhe só pra nós! O que temos para dar ao menino?

Tony - Não pode fazer isso! Não agora! Não depois de tudo que passamos.

Pai - É pelo pequeno Billy! Ele pode ser um gênio, por tudo que sabemos.

Tony - Pai, não pode fazer isso, cara!

Pai - Tony! Ele só tem 11 anos, pelo amor de Deus.

Tony - É só uma criança! Ele é só uma criança! Pai. Por favor.

Pai - Sinto muito, filho. Estamos quebrados, filho. Que escolha nós temos? Vamos dar uma chance ao menino.

(DALDRY, 2000)

O enunciado de que o filho possui um dom é agora pronunciado pelo pai: "Ele pode ser um gênio, por tudo que sabemos", é preciso dar-lhe uma chance. O pai não possui o conhecimento específico que permita dizer se o garoto tem ou não potencial na área, mas confia na palavra da professora. Talvez o menino não passasse no concurso, talvez não se desenvolvesse no balé. Mas não é o sucesso do filho que se apresenta como responsabilidade do pai e sim o fato de dar-lhe uma chance confiando na palavra da professora.

O apoio do pai se constrói como essencial, mesmo ele não sendo capaz de compreender a individualidade do filho. Na Academia Real de Balé, Billy faz o teste e os avaliadores entrevistam pai e filho. Ao pai, perguntam:

\footnotetext{
Avaliador - Sr. Elliot, o senhor é um apreciador do balé?

Pai - Não diria exatamente que sou um especialista.

Avaliador - Esteja consciente que todos os alunos devem manter os mais altos padrões, não apenas no balé, mas também em seus estudos escolares. Nenhuma criança se desenvolve sem ter 100 por cento de apoio da família. O senhor apoia Billy integralmente? Não apoia?

Pai - Sim. Sim, claro.

(DALDRY, 2000)
}

"Nenhuma criança se desenvolve sem ter $100 \%$ de apoio da família". A frase é pronunciada, no filme, pela principal figura de autoridade, aquele que tem experiência na área, que é o responsável por escolher quais crianças têm potencial para se tornarem grandes dançarinos em meio a centenas que são rejeitadas. A afirmação é feita de forma enfática e generalizante: nenhuma criança, 100\% de apoio. A regra se apresenta como universal. Todos os pais devem apoiar integralmente a individualidade de todos os filhos. 
Figura 2 - Cena do filme Billy Elliot em que a comissão de especialistas da Academia Real de Balé avalia Billy e alerta o pai sobre a necessidade de apoiar $100 \%$ o filho..

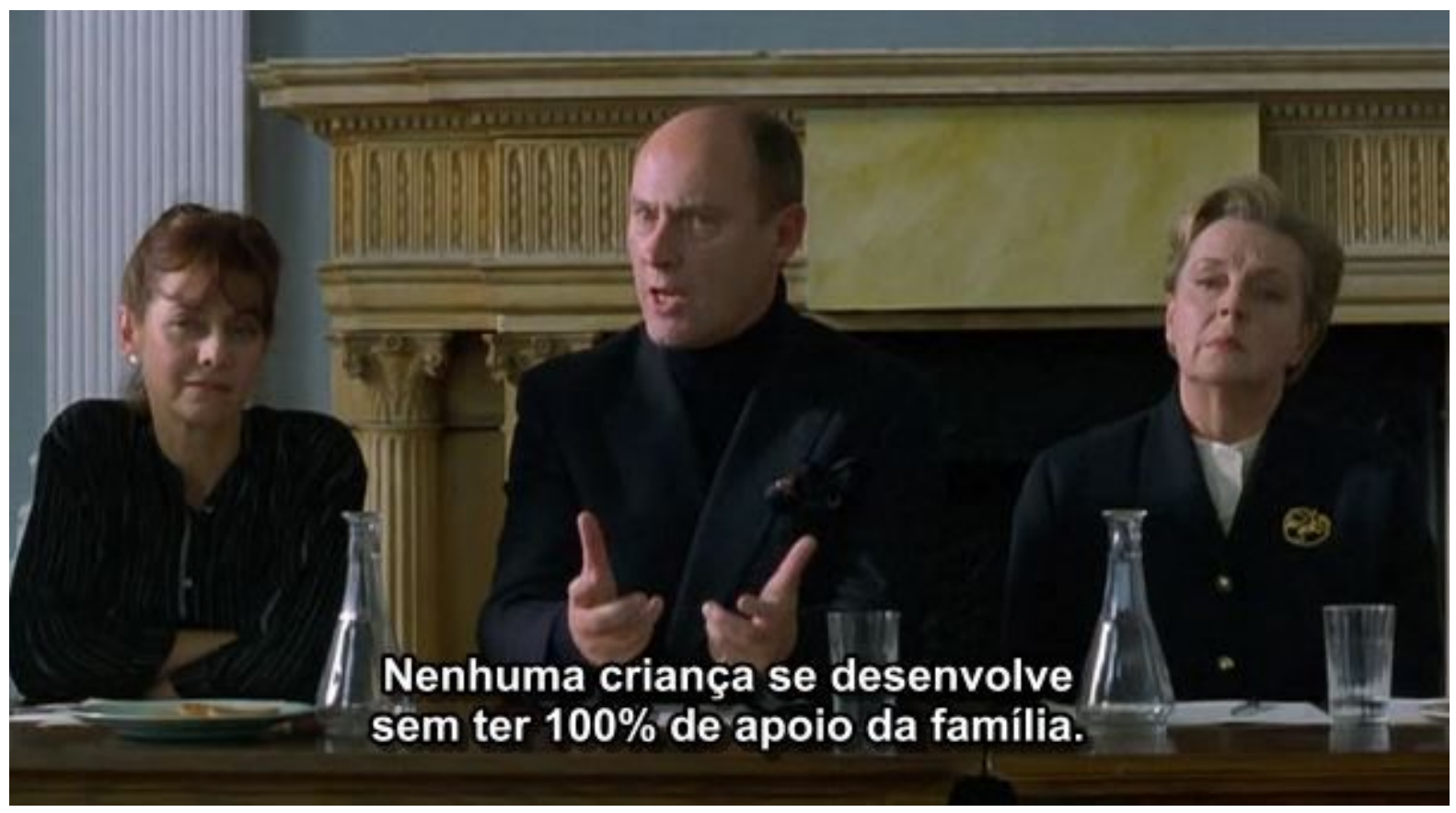

Fonte: print screen do filme Billy Elliot.

Ao Billy, o avaliador pergunta:

Avaliador - Só mais uma coisa. Posso lhe perguntar, Billy. Como se sente quando está dançando?

Billy - Não sei. Eu me sinto bem. No começo é difícil, mas depois que começo, eu me esqueço de tudo. E... desapareço. Parece que eu desapareço. Eu sinto uma mudança no meu corpo todo. Como se tivesse um fogo. E eu fico ali. Voando. Como um pássaro. Como a eletricidade. É. Eletricidade.

(DALDRY, 2000)

Qual é a pertinência da pergunta nessa situação? O avaliador está interessado, neste momento, não nas capacidades intelectuais ou físicas de Billy, mas em como ele se sente. Há uma associação entre o dom, a vocação, e a realização de um desejo, como se o desenvolvimento do dançar estivesse ligado ao desenvolvimento da própria personalidade, da individualidade de Billy. A resposta de Billy, por sua vez, confirma a expectativa, tratando o dançar como uma energia vital, como "um fogo", "uma eletricidade".

O filme termina com o sucesso de Billy, anos depois, se apresentando como estrela no balé $O$ Lago dos Cisnes, teatro lotado, pai, Tony e Michael presentes. Um assistente avisa 
Billy que sua família está presente. No auge da música todos os dançarinos saem de cena e Billy entra dando um salto. Os próprios dançarinos olham com admiração, assim como a família. Corta a cena e entra a mesma música inicial com o Billy, criança igualmente pulando em sua cama enquanto sobem os créditos. Essa última sequência constrói uma imagem final: o salto, o potencial, já estava lá no Billy criança.

Duas grandes descontinuidades, portanto, entre Billy Elliot e os filmes e o livro analisados nos capítulos anteriores. As personagens que podem enunciar quais aptidões correspondem ou não a vocações da criança mudaram. Se, como vimos, em Misunderstood, de 1869, era o pai quem dizia ao filho qual era ou não a vocação da criança (MONTGOMERY, 1960, p. 47), em Billy Elliot essa posição não é mais ocupada por nenhum membro do núcleo familiar, mas por um especialista externo, a professora de dança, que identifica o potencial de Billy para a dança como um dom. Esse deslocamento do enunciador da vocação é condição de possibilidade para a construção da criança incompreendida em Billy Elliot, uma vez que a incompreensão não se liga mais nem à altivez mal compreendida pelo pai como "ausência de coração" (Incompreendido de 1869), nem como imprudência gerada em resposta a uma estratégia impositiva (Quando o Amor é Cruel, Noviça Rebelde e Mary Poppins, todos da década de 1960), mas à dificuldade de pai em compreender a construção da individualidade do filho de modo diverso daquela imaginada por ele, uma vez identificadas a paixão e o potencial para a dança.

Ainda, o enunciado "os pais devem aceitar os filhos como são" se torna uma questão central. Em Billy Elliot, aparece na carta da mãe ("seja sempre você mesmo") depois, como condição colocada pelos membros da academia ao pai para que Billy pudesse se desenvolver ("Nenhuma criança se desenvolve sem ter $100 \%$ de apoio da família") e, por fim, na própria conversão do comportamento do pai que leva ao sucesso do filho.

A incompreensão do Billy se deve ao fato dele apresentar um potencial para a dança que não é inicialmente reconhecido pelo pai, potencial que se revela cedo, como uma oportunidade de mudança de status. O efeito de fechamento, que garante o papel pedagógico do filme ao ensinar os pais como lidar com os filhos, é construído por meio do sucesso profissional. O pai "deu uma chance" ao filho, como ele mesmo diz, apesar de ter demorado a reconhecer o talento e a paixão de Billy. O custo foi o sacrifício individual de abrir mão da 
greve. A recompensa é o sucesso do garoto como estrela principal do espetáculo $O$ Lago dos Cisnes, que fecha o filme. O destino do filho é diretamente e exclusivamente ligado à aceitação por parte do pai. Praticamente nenhuma outra variável é articulada nessa construção.

O professor Júlio Groppa Aquino, em uma palestra que levou o nome de "A família no fogo cruzado da educação contemporânea", se vale do filme Billy Elliot para realizar algumas provocações sobre família e nossa forma de se relacionar com as crianças. Em sua fala, Aquino enfatiza o "acosso da experiência educativa", uma vez que, de acordo com o professor, não sabemos o que é ser um bom pai ou uma boa mãe em relação a como educar as novas gerações. Esse acosso teria se transformado em um nicho de mercado dos especialistas "psi", as "autoridades conselheiras" que nos dizem como viver e, gradativamente, vão desautorizando nossos gestos e qualquer experiência do inédito. $\mathrm{O}$ autor finaliza por defender uma reinvenção da experiência educativa que permita às crianças um pouco de sofrimento e que as deixa "em paz”, sem uma vigilância absoluta. O filme, Billy Elliot, é descrito, no início da apresentação, à luz da teoria do sociólogo Zygmunt Bauman e serve como disparador para a discussão. A ênfase da fala é na passagem da família do mundo sólido, marcada pela segurança, à família do mundo líquido, marcada pela liberdade. As cenas selecionadas ilustram o sacrifício do pai e um projeto de família ligado à ideia de ser superado pelos filhos, de acordo com Aquino, quase inexistente nas camadas médias urbanas da população nos dias de hoje (AQUINO, 2011).

A dimensão do sacrifício, colocada discursivamente em jogo em Billy Elliot, é construída na relação com o uma possibilidade, com um "dar uma chance para o garoto", uma vez identificado um potencial por uma professora. A figura da especialista que aparece não é a da especialista $p s i$, mas a de uma autoridade em uma determinada área, no caso a professora de balé, que enuncia um potencial do filho não reconhecido pela família. Ela não desautoriza os gestos do pai, mas transfere para ele a responsabilidade sobre o sucesso ou fracasso do filho. Uma vez reconhecido o potencial, cabe ao pai dar ou não uma chance ao filho e arcar com as consequências. 


\subsection{Minha Vida em Cor-de-Rosa}

Em Minha Vida em Cor-de-Rosa (BERLINER, 1997), a família de classe média Fabre tenta sobreviver ao competitivo subúrbio francês. A família é composta pela mãe Hanna, pelo pai Pierre, por três filhos e complementada pela presença da avó Elisabeth. A trama central do filme é a relação da família com o filho Ludovic (7 anos), que quer ser menina e se casar com um menino. Trata-se de um filme sobre a relação entre pais e filhos em que o problema central é, a princípio, uma questão de identidade de gênero e sexualidade.

O filme começa com cenas do mundo imaginário do programa televisivo de Pam, que é mimetizado por Ludovic, e no qual ele se refugia em pensamento em momentos posteriores. Após mostrar o mundo mágico e cor-de-rosa de Pam, o filme apresenta três casais diferentes, um por cena, se arrumando para a festa de recepção dos Fabre, que acabaram de se mudar para uma casa no subúrbio com seus quatro filhos. Os três casais repetem, enquanto conversam, o mesmo gesto: marido e esposa se arrumando para a festa, mulher de vestido, homem de calça e camisa. Todos se dirigem à residência dos Fabre e o pai discursa. As cenas do discurso se intercalam com as cenas de Ludovic se maquiando e se arrumando com um vestido cor-de-rosa e brincos.

Sr. Fabre (pai) - Sejam todos bem-vindos. Venham quando quiserem! Serei breve. Quero apresentar-lhes minha tribo. A mais bela...

Avó - Puxou à mãe!

Sr. Fabre (pai) - Minha esposa, Hanna. Meu filho mais velho, Tom, o "inteligente". O segundo, Jean, o "danado". E o resto da prole... Zoé, por exemplo Zoé... Ludovic.

Zoé (sobre a roupa de Ludovic)- É o meu vestido de princesa.

Sr. Fabre (pai) - Ele é Ludovic, o "brincalhão". Essa é a sua piada favorita! (BERLINER, 1997)

Após o ocorrido, dentro de casa, na ausência dos convidados, o pai repreende o filho. A mãe não apoia, mas não demonstra grande preocupação. A avó, ao questionar sobre a regularidade com que o menino se "veste de menina" e ao indicar que aos 7 anos Ludovic já saberia referir a si mesmo no masculino, como bonito [beau] e não como bonita [belle], parece identificar no comportamento o sintoma de alguma questão identitária.

Mãe - Você já tem 7, Ludo. É muito velho para se vestir de menina. Mesmo que ache divertido.

Pai - O que deu em você? 
Ludovic - Eu queria ficar bonita [belle].

Pai (para Ludovic)- Que seja a última vez.

Pai (para a mãe) - Precisamos de mais coisas.

Mãe - Já vou.

Avó - Você faz isso sempre?

Pai - Não! Só de vez em quando.

Mãe - É normal. Até os 7 anos procuramos nossa identidade. Li isso numa uma revista.

Avó - Aos 7 anos, dizemos "bonito" [beau].

(BERLINER, 1997)

O filme continua identificando Ludovic com outros estereótipos associados a meninas. $\mathrm{Na}$ escola, todos levam brinquedos para uma atividade proposta pela professora. A primeira a revelar o brinquedo é Sophie, que levou bonecos de Pam e Ben. Outras crianças estão, a maioria, com brinquedos eletrônicos. A professora questiona Ludovic, que retira da bolsa bonecos de Pam e Ben iguais aos de Sophie, o que é motivo de risada para os outros alunos.

\footnotetext{
Professora - E você, Ludo?

Colega de sala - Ele brinca com bonecas!

Professora - Shh... Vejo que Pam e Ben são populares. Você quer ser como Ben, certo?

[Ludovic nega discretamente balançando a cabeça.]

Professora - Você e Sophie fariam um belo casal.

(BERLINER, 1997)
}

Além de se vestir com roupas caracterizadas socialmente como femininas, Ludovic gosta de brinquedos igualmente vistos pelo grupo como femininos. A professora, ao insistir que ele deve se reconhecer como Ben e que, pela afinidade do gosto pelos bonecos, faria um belo casal com Sophie ainda associa o gosto e a orientação sexual.

A professora continua a atividade se direcionando a Jêrome, filho do chefe do pai de Ludovic. Jêrome, na cena do vestido, é o único que olhara para Ludovic de forma sem se espantar. Agora, mostra seu brinquedo: um caminhão. De dentro do caminhão, porém, retira um pingente. Ludovic olha surpreso. É o pingente que ele estava usando na festa. A professora novamente contém a turma e diz a Jêrome que "não se esqueça de devolver a sua mãe", deixando subentendido que o pingente não poderia ser do próprio garoto. Na cena seguinte, Ludovic se aproxima de Jêrome no recreio e o colega lhe devolve o pingente. 
Ludovic gentilmente oferece o pingente a Jêrome: "Pode ficar, minha mãe acha que perdeu." Os dois sorriem.

É a avó que vai buscar Ludovic na escola, de carro e pergunta:

Avó - Ele não é o filho do chefe de seu pai? São amigos?

Ludovic - Sim! Vamos nos casar quando eu não for mais menino.

Avó - Quando você não for mais menino?

Ludovic - Claro.

Avó - Você tem muito a me ensinar.

(BERLINER, 1997)

Na casa da avó, eles assistem ao programa televisivo de Pam, uma mulher de vestido vermelho e cabelos longos, maquiada, que vive em uma casa colorida de plástico, voa e sopra um pó mágico que faz aparece Ben, um homem loiro carregando flores e que lhe pede em casamento.

Ludovic - Vó! Vó! Vai começar.

Narrador (som da televisão) - E aqui está Pam, a heroína de seu programa de TV favorito.

Ben - Pam, casa comigo?

Pam - Oh, sim, Ben!

Trilha sonora da televisão (Ludovic canta junto)- Eu leio todos os livros sobre romances e rosas, sublinho todas as partes que o namorado pede em casamento, com lápis rosa. Desejo ser feliz. É como uma neurose.

(BERLINER, 1997)

A avó dança junto com o neto e lamenta que quase não tenha convivido com ele nos últimos 5 anos. Depois, utiliza a oportunidade e fala ao garoto sobre adequar-se à realidade e deixar os devaneios não aceitos socialmente para momentos privados de fantasia:

Avó - Gostaria de ser ainda como ela, magra, sem rugas. Mas esse vestido, na minha idade... Ficaria ridícula.

Ludovic - Não ficaria, você é linda!

Avó - Obrigado, meu amor.

Ludovic - De nada.

Avó - Mas todos temos de encarar a realidade. Sei de um truque para fazer coisas sem que pareça ridícula. Quer saber qual é?

Ludovic - Sim!

Avó - Veja. Fecho os olhos...

Ludovic - Fecho os olhos.

Avó - E o mundo se torna o que eu quero.

Ludovic - E o mundo se torna o que eu quero: sou jovem, bela...

(BERLINER, 1997) 
Ao dizer a última frase, Ludovic se imagina com um vestido brilhante na casa colorida de Pam, se olhando no espelho feliz. Continua o filme relacionando Ludovic a padrões de gênero femininos, agora com o corte de cabelo. Ele, que tem o cabelo comprido até a altura do queixo, se recusa a cortar, mesmo sob insistência da mãe. A mãe convence que cortará só um pouco e puxa conversa com Ludovic sobre o que disse à avó:

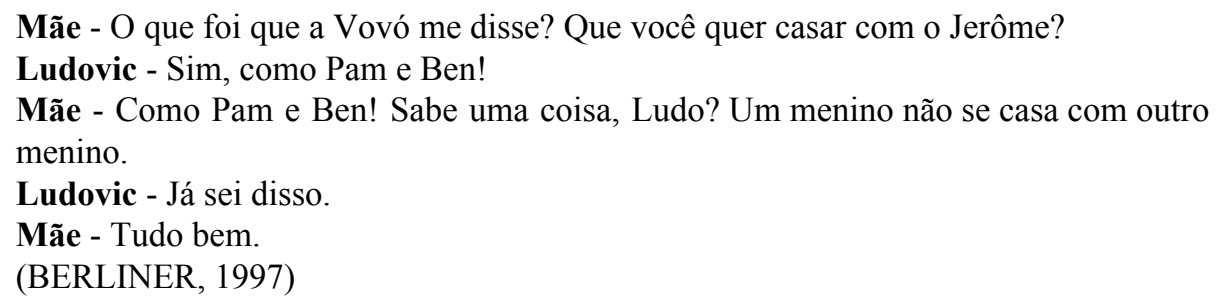

A sucessão da apresentação de estereótipos de gênero, somada ao veto da mãe de que o filho se relacione com outro garoto, parece reforçar a identidade de Ludovic, como menina. A construção indica que Ludovic não vê problemas no veto porque acredita que não será mais menino. Não há nenhuma menção à idade deles. O problema, para a mãe, neste momento, não é o fato de uma criança de 7 anos desejar se casar com outra, mas o fato da outra ser do mesmo gênero.

Ludovic e a mãe vão à casa da família de Jêrome. A mãe de Jêrome faz um vestido para a mãe de Ludovic. Essa, em troca, corta os cabelos daquela. Jêrome apresenta a casa para Ludovic. Há um quarto proibido. É da irmã de Jêrome. "Ela partiu”, ele diz. Mas Ludovic entra mesmo assim e pega um vestido da irmã falecida. Eles encenam um casamento, Jêrome como Ben e Ludovic como Pam. A mãe de Jêrome observa-os pela porta. $\mathrm{Na}$ hora do beijo, ela desmaia. Ludovic imagina Pam magicamente aparecendo e resolvendo todos seus problemas, tirando as mães do caminho e voando com ele e Jêrome. Até que ele cai e volta à "realidade".

Mãe - Não percebeu o que você fez? A irmã de Jerôme morreu!

Ludovic - Eu não sabia, ele me disse que ela tinha ido embora.

Mãe - Isso não é desculpa para esse comportamento, você já tem 7 anos. O que há, Ludovic?

Ludovic - Um dia me casarei com Jerôme.

Mãe - O quê? Mamãe tinha razão. Mentiu para mim. Eu já te disse que um menino não se casa com outro menino. Bom, às vezes...

Ludovic - Mas, serei menina. 
Mãe - Não quero ouvir tolices. Você é menino. E será menino toda sua vida. Você é muito teimoso! Assim como a mãe.

(BERLINER, 1997)

Ludovic enuncia agora, não mais na negativa, e de forma clara: será uma menina. A mãe repreende, se exalta, mas, ao final sorri e demonstra carinho. O mesmo acontece, na cena seguinte, com o pai. Família sentada à mesa, o pai se irrita com o ocorrido: "Jerôme é filho do Albert, o chefe do papai. Então não use roupas de meninas com o Jerôme. Nem com ninguém!" Mãe e irmã tentam acalmar os ânimos. O pai se levanta nervoso. Ludovic se levanta e segue-o até o jardim e lhe oferece a mão. Os dois dão as mãos e voltam abraçados para dentro de casa.

As duas cenas reforçam o carinho dos pais pelo filho ao mesmo tempo que mostram a insatisfação e o desconforto deles com a situação. Não compreendem Ludovic e se irritam. Mas, mesmo nesses momentos, o carinho está presente. Afasta-se, portanto, a possibilidade de que se relacione a incompreensão à falta de carinho.

Na cena seguinte, manhã do outro dia, Ludovic prepara o café da manhã dançando e a mãe repara que ele vestiu o short com os botões para trás. Ela, então, diz ao marido que está de acordo com o que conversaram. Na sequência, todos entrando no carro do pai de Jêrome, chefe do pai de Ludovic, Sr. Fabre anuncia ao superior: "Tomamos uma decisão. Ludovic irá ao psicólogo. Isso vai resolver, garanto. Um dia riremos disto." Não sabendo mais o que fazer, recorrem a um especialista. O fato do pai contar ao chefe sobre o encaminhamento indica também que essa decisão é apaziguadora, é socialmente bem vista como uma busca por solução em face a um comportamento considerado problemático e pelo qual os pais são vistos como responsáveis.

No consultório, a psicóloga questiona sobre o desejo dos pais em relação ao sexo biológico do filho.

Psicóloga - Vocês queriam que ele fosse o quê?

Mãe - O que quer dizer?

Pai - Como assim, "fosse o quê"?

Psicóloga - Menina ou menino?

Pai - Dava no mesmo. O que viesse seria um presente de Deus.

Mãe - Já que estamos aqui terá que dizer a verdade.

Pai - Qual verdade?

Mãe - Como já tínhamos...uma menina e dois meninos...lembro de dizermos que seria bom ter outra menina. 


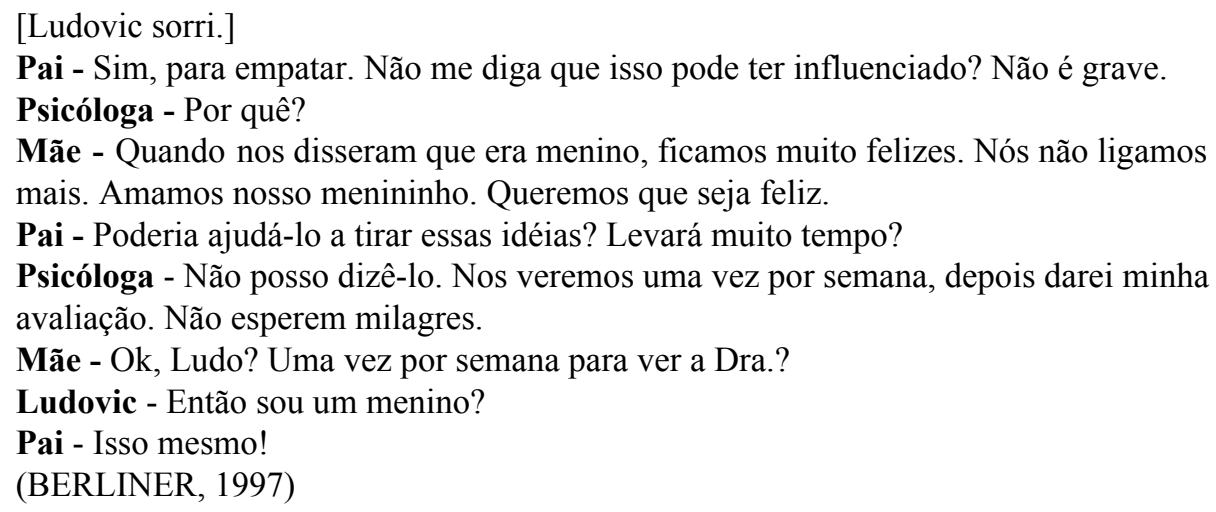

A pergunta constrói uma relação entre o comportamento atual de Ludovic e o comportamento passado dos pais, ainda que essa relação seja efetivamente pronunciada como uma indagação dos pais, em reação à fala da psicóloga. Os pais pedem ajuda para "tirar essas ideias" do garoto. A doutora não promete nada, mas não instrui na direção contrária. Apenas diz para que não esperem milagres.

Ludovic, que agora tem a palavra dos pais de que ele é um menino referendada pela psicóloga, ou pelo silêncio de um diálogo que acontece na presença da psicóloga, guarda todas as suas bonecas. Olha os irmãos brincando de bang-bang e imita-os em frente ao espelho. Depois, leva a mãos às genitálias, mimetizando um gesto socialmente visto como um clichê masculino. Ele, ainda na tentativa de se adaptar agora aos padrões masculinos, repete o gesto na frente de Sophie e tenta beijá-la. Ela empurra-o e diz que não beija garotas.

Conversando com os outros adultos sobre os eventos recentes, em um almoço coletivo, alguém fala sobre uma matéria que viu na televisão sobre transsexuais. É a única vez que a palavra é pronunciada no filme. Ela prossegue dizendo que é triste e que não sabe o que faria se fosse a filha dela. Cada adulto, então, dá palpites sobre como a família deveria lidar com aquilo que é visto como um problema. Thierry diz que "O que serve é fazer esportes". A avó, até então apresentada aparentemente como compreensiva, apresenta sua visão: “Acho que devemos deixá-lo viver sua fantasia.(...) O filho de uma amiga queria ir de saia à escola e ela deixou. (...) Depois de 7 dias ele guardou a saia.”. No interior da casa, o pai conversa com Albert, seu chefe, sobre trabalho. Sr. Fabre tenta tranquilizar Albert sobre a relação entre os filhos, mas a conversa se torna, igualmente, um novo conselho aos pais, desta 
vez, indicando que o comportamento de Ludovic deveria ser uma consequência à influência excessiva da mãe:

Pai - Ludo é estranho, mas ele é inofensivo. A terapeuta deu um jeito nele.

Albert - Quer um conselho de amigo? Seu filho não precisa de psicólogo.

Pai - Então o quê?

Albert - - Não deixe que Hanna tome sozinha decisões com seus filhos.

Pai - Ela não toma.

Albert - - Não leve a mal.

Pai - Criamos todos igualmente. Mas não são produtos em série, são diferentes. Você não sabe porque só tem um filho.

[Albert abaixa a cabeça]

Desculpe, esqueci.

Albert - Deus me tirou um filho e não me tirará outro.

Pai - Entendeu-me?

Albert - Acalme-se!

Pai - Desculpe-me!

(BERLINER, 1997)

O pai resolve passar mais tempo com Ludovic e leva o filho para jogar futebol. Os conselhos não foram ignorados. Ludovic, confuso, conversa com a irmã e pergunta sobre sua própria identidade de gênero.

Ludovic - E então, sou menino ou menina?

Irmã - Não me pergunte! Em biologia vemos por quê somos meninos ou meninas.

$\mathrm{XY}$ é um menino. XX é uma menina. É como no pôquer. Entende?

Ludovic - Não é Deus quem decide?

Irmã - Sim, é óbvio.

(BERLINER, 1997)

Logo após a explicação, Ludovic sonha com Deus deixando cair um X que deveria lhe atribuir para que fosse efetivamente menina. Em conversa com Jêrome, no banheiro, ele faz xixi sentado e depois explica sua situação: "sou menino-menina".

Ludovic - Primeiro tem de entender: sou um menino-menina.

Jêrome - Um menino-menina? Está louco!

Ludovic - Espere! Para fazer um menino, os pais brincam de adedanha. Certo?

Jêrome - Sim, ok.

Ludovic - Venha. Quando um ganha, Deus manda os X e os Y. XX para meninas, $\mathrm{XY}$ para meninos. De acordo? O meu X caiu no lixo. Em seu lugar ficou um Y. Foi um engano científico.

Jêrome - Ande, rápido.

Ludovic - Mas Deus consertará. Ele vai me mandar meu X e poderemos nos casar.

Jêrome - Depende de que tipo de garota você é.

(BERLINER, 1997) 
A situação se agrava quando Ludovic, tranca Sophie em uma sala e ocupa o lugar dela como Branca de Neve na apresentação da escola. Alguém pisa no véu de Ludovic durante a cena e revela-se, na frente de todos os pais e espectadores, que é ele que está esperando o beijo de Jêrome. A família Fabre sai do teatro sob os olhares de todos.

$\mathrm{Na}$ cena seguinte, à mesa, todos da famíla menos Ludovic, conversam sobre o ocorrido.

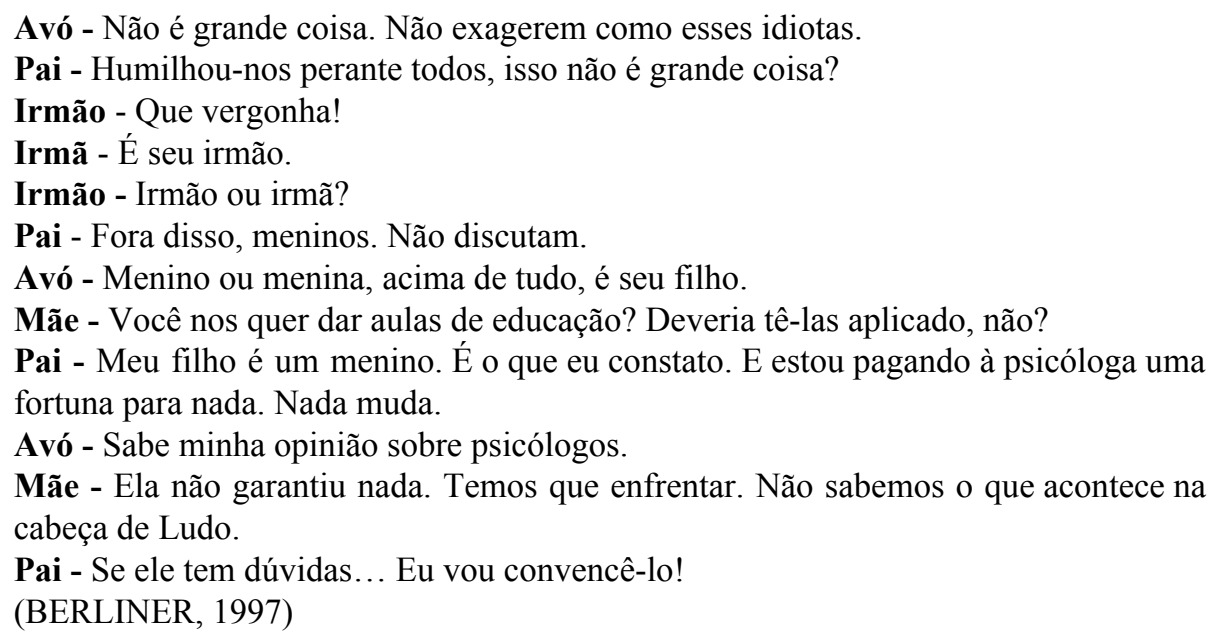

O que o incomodou os pais, na forma como se enuncia a questão, não foi o fato do filho ter trancado a colega e roubado seu papel, mas o fato de ter humilhado a todos por se vestir de branca de neve para beijar Jêrome. Quando o pai se dirige, nervoso, na direção de Jêrome, a mãe intervém e impede. Depois, conversando com a avó, o garoto, triste, diz o que esperava dos pais:

Avó - Calma, logo passa.

Ludovic - Dizem que é má vontade, me nego a mudar e que só lhes dou problemas.

Avó - Eles têm certa razão.

Ludovic - É verdade que eu não mudei, mas... Quero que me amem, mesmo assim.

Avó - Eles te amam, querido.

Ludovic - Tudo o que fazem é para seu bem.

Avó - Não é para o meu bem!

(BERLINER, 1997)

Ludovic quer ser amado independente de ter mudado ou não. Na psicóloga, ele explica sua teoria sobre o X que se perdeu e que é "menino-menina". O pai se enfurece e levanta raivoso:

Pai - "Menino-menina"! Pelo amor de Deus! 


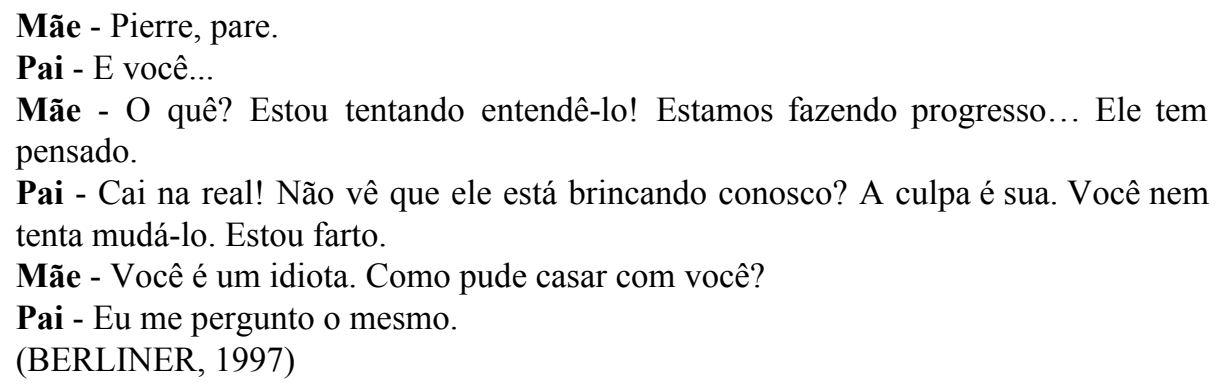

A mãe tenta compreendê-lo, entender a lógica do filho; o pai tenta mudá-lo, ajustá-lo à lógica da sociedade em que vivem. A constatação das diferenças é visto como uma incompatibilidade. O pai se zanga com a mãe porque ela não tenta mudar o filho, a mãe se zanga com o pai porque ele não tenta compreendê-lo. A incompatibilidade em relação à forma de lidar com a questão é vista mesmo como algo que deveria interferir na própria decisão do casamento, como uma condição prévia.

A professora, que tentava controlar a turma ajustando Ludovic, agora assume uma fala de tolerância e respeito às diferenças, mas o diretor da escola convoca os pais de Ludovic para informar sobre a expulsão do garoto por solicitação dos outros pais.

Diretor - Lamento muito, mas o comportamento e gostos de Ludovic são muito excêntricos para esta instituição. Consultaram um especialista?

Pai - Claro que sim!

Diretor - E o que disse?

Mãe - Que é "terapia, não mágica", que leva tempo.

Diretor - Estou de acordo, mas eu tenho esta petição...

Pai - Petição?

Mãe - É insensato.

Pai - Absurdo.

Mãe - Meu filho fez uma besteira, ele não matou ninguém. Sabe o que pode fazer com sua petição?

Pai - Hanna.

Mãe - O quê? Ele me irrita.

[batidas na porta]

Diretor - Sim, entre.

[Ludovic entra em cena]

Diretor - Eu compreendo a Sra., mas como diretor da escola não posso ignorar a assinatura de 20 pais. Todos assinaram a petição.

Pai - Todos? Até os Bruns e os Letieux?

Diretor - Todos.

(BERLINER, 1997)

Pessoalmente, indica-se que tanto professora quanto diretor são contrários à decisão. Porém, como diretor, ele diz não poder ignorar as demandas dos outros pais. É a pressão dos 
pais que determina as ações da escola. Ludovic vai para outra escola. Uma hora mais distante do que a antiga. Agora é a mãe que se cansa do filho e exige que ele se adeque aos padrões da nova escola:

Mãe - Uma hora para a escola, ao invés de 5 minutos. Sei que tem de buscar sua identidade, mas francamente!

Ludovic - Só um X a mais...

Mãe - Cale-se. Fique calado na escola, ou vai acontecer o que aconteceu antes. (BERLINER, 1997)

Após um jogo de futebol, os meninos decidem bater em Ludovic no banheiro. Jêrome simplesmente pega suas coisas e sai sem falar nada. Um dos irmãos se levanta para tentar impedir, mas o outro irmão o segura. Ludovic desaparece. Os pais o encontram dentro do congelador. Com o ocorrido, a família toda fica reunida em torno de Ludovic. Os pais dizem que vão "começar do zero" e para o menino escolher o que quer fazer. Ele pede para "ir de saia à festa de Sophie". O pai resiste, mas decidem adotar a estratégia da avó e aceitar como uma fase passageira. Na festa, com Ludovic de saia, eles explicam aos demais "É uma cura. Estamos deixando ele viver sua fantasia para banalizá-la. Se não é proibido, fica menos interessante." Todos sorriem e dançam. A trilha sonora alegre, porém, é logo interrompida. $\mathrm{O}$ pai perdeu o emprego. Embriagado, ele conta à família e diz que vai lutar. Ludovic questiona se é o culpado pela demissão.

Ludovic - É por minha culpa?

Pai - Não! As pessoas são nojentas.

Mãe - Bando de hipócritas. Todos sorrindo no aniversário... Estou farta de hipocrisia. Sim, tudo que se passa conosco é culpa sua, tudo!

Pai - Crianças, calma. Mamãe está cansada, precisa dormir. Amanhã irá sentir-se melhor.

(BERLINER, 1997)

A psicóloga fala agora apenas com Ludovic:

Psicóloga (sozinha com Ludovic) - Nada mais para dizer? Não quer mais falar comigo? Existem coisas que seus pais nunca entenderão, Ludovic. Quando for grande poderá dizer o que pensa. Entende?

Psicóloga (à mãe) - Ludo não tem falado comigo há semanas. Quando uma criança faz isso, é hora de parar.

Mãe - Tem que continuar, é o seu trabalho.

Psicóloga - Só posso ir até onde ele permitir.

Mãe - Mas...

Psicóloga - O vazio é assustador, mas pode nos ajudar a nos conhecer melhor. (BERLINER, 1997) 
A fala revela um papel mediador da psicóloga. Ao contrário do que fora solicitado pelos pais, ela não tentara modificar o comportamento do garoto, apenas auxiliá-lo em sua autocompreensão e na compreensão de Ludovic pelos pais.

Ludovic acorda com dor de barriga e acha que são cólicas como a da irmã. Antes que possa descer do quarto, vemos o pai chorando ao lado de fora da casa. "Fora viados", diz uma pichação no portão da garagem. A mãe abaixa-se para consolar o marido. Chega Ludovic gritando que está com cólicas menstruais. A mãe, séria entra com o filho. Ele pergunta o que é um "viado" [tapette]. A mãe, ligando a máquina para cortar-lhe os cabelos, responde que "viados são meninos que gostam de meninos, como você". Os dois choram enquanto a mãe corta o cabelo do filho. Ludovic se revolta. Diz que odeia os pais e que quer ir morar com a avó. E vai.

O pai, no entanto, consegue um novo emprego em outra região. Ludovic deve decidir se vai com os pais ou se fica sozinho com a avó, distante deles. Ludovic decide ir. Já na casa nova, o garoto sai para passear. A mãe o questiona:

\footnotetext{
Mãe - Para onde vai?

Ludovic - Passear. Fazem muito barulho.

Mãe - Não é nossa culpa estarmos aqui, certo?

Pai - Não acha que está sendo muito dura com ele? Está melhor desde que nos mudamos. Talvez ele tenha superado.

(BERLINER, 1997)
}

A dinâmica entre o casal se repete: quando o pai se exalta, a mãe contemporiza, mostra-se compreensiva; quando a mãe se exalta, o pai contemporiza. A mãe, em Minha Vida em Cor-de-rosa, não tem individualidade em relação à família e é apresentada apenas na figura de mãe, sem outros projetos além do cuidado doméstico e com os filhos. Nas primeiras cenas do filme, ela se refere a esse lugar de forma irônica quando, logo após mudarem para a casa dos subúrbios. O marido pergunta se está gostando da nova vida, ao que ela responde: “Vamos ver: 'Esquente as pizzas... coloque os aperitivos lá fora e prepare os canapés'. Isso é tudo? Não. Também sinto-me... muito orgulhosa de você, Sr. Fabre.” Ela não afirma que se sente bem, mas aceita a situação pelo marido. Apesar da dinâmica familiar ser marcada por diferenças entre os gêneros, na dinâmica do relacionamento com Ludovic, as diferenças de 
gênero não aparecem. Tanto pai quanto mãe devem compreender o filho e um deve controlar os excessos do outro.

Ludovic se senta à beira da estrada em frente a um outdoor com uma grande propaganda do programa de Pam. É sentado nesse banco que ele é surpreendido por Christine. Uma menina ruiva de cabelos curtos e roupas socialmente consideradas masculinas, que brinca com um estilingue. Ludovic é convidado para o aniversário de Christine. A aniversariante veste, a contragosto, um vestido de princesa. Ludovic veste uma fantasia de um cavaleiro com chapéu. Ela pede para trocar de fantasia com ele. Quando ele se recusa, dizendo que não pode, ela força-o e chama ajuda. A mãe, ao ver Ludovic com o vestido de Christine, no bairro novo, corre atrás dele gritando e lhe dá um tapa. As outras mães seguram-na para que pare. Christine esclarece que foi ela que forçou a troca. Ludovic desaparece. A mãe corre desesperadamente atrás dele. Procura no congelador, anda pela estrada e vê o cartaz de Pam com uma escada. Ao subir, a mãe vê Ludovic no mundo de Pam gritando:

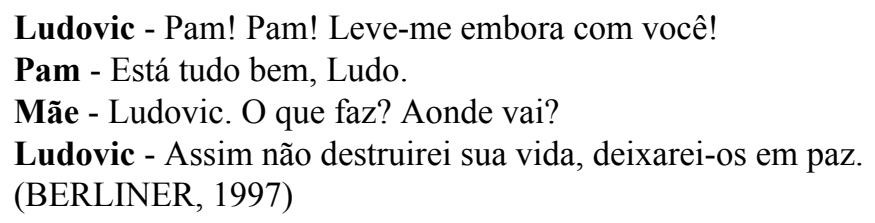

A demanda do filho, apresentada anteriormente, era que os pais o amassem mesmo se não fosse capaz de mudar. Quando os colegas batem nele por que é diferente, ele tenta se matar no congelador. Quando a mãe tenta modificá-lo, ele vai morar com a avó. Agora, quando enfim tentava se adequar, ainda que infeliz, e vê a tentativa frustrada, se percebe como um entrave na vida dos pais e tenta fugir da realidade, refugiando-se no outdoor do mundo de Pam. A mãe tenta entrar no mundo de Pam para segui-lo, mas afunda no chão e acorda no sofá. O pai conversa com a mãe que retoma consciência:

Pai - Meu amor... Hanna. Hanna. Por quê você subiu no anúncio?

Mãe - E Ludovic?

Pai - Ludovic...

Mãe - Não foi com a boneca, certo?

Pai (expulsando as outras pessoas que observavam) - Foi só um choque. Está tudo bem. Vamos tomar um drinque lá fora. Vamos inaugurar a casa.

Ludovic - Vou me vestir normal.

Pai - Faça como quiser.

Mãe - Aconteça o que acontecer, é meu filho.

Pai - Nosso filho. 
Mãe - Sim, nosso filho. Ultimamente havia esquecido disso. Mas, agora tudo ficará bem. (BERLINER, 1997)

Pam passa voando sobre a casa, olha para o espectador e pisca. Fim.

Minha Vida em Cor-de-rosa, ao contrário de Billy Elliot, não coloca em segundo plano as questões sobre sexualidade e identidade de gênero para destacar a questão do dom. Inversamente, remete tudo à uma questão identitária. Os gostos por bonecas, o corte de cabelo, vestir-se com vestidos, assistir Pam, gostar de Jêrome, tudo isso converge para a identidade de Ludovic como "menino-menina" ou apenas como menina. Ainda assim, mesmo utilizando uma estratégia aparentemente oposta à de Billy Elliot, a norma que se constrói é a mesma. Aos pais cabe aceitar o filho como ele é, mesmo quando a individualidade dele se manifesta ou se constrói de forma incompreensível para a família.

Em Minha Vida em Cor-de-rosa, a especialista externa à família é uma psicóloga, uma especialista em sexualidade, em identidade, em gente. Assim como nos filmes anteriores, Ludovic tem uma característica que é reconhecida como inelutável por um outsider em posição de legitimar uma característica não reconhecida pela família. Não se trata aqui de um dom reconhecido e de uma oportunidade para desenvolvê-lo, mas de uma característica identitária contra a qual seria inútil se opor. Ludovic era incompreendido porque os pais queria transformar uma característica que cabia a eles apenas aceitar. Ao final, os pais são reconvertidos: "Faça como quiser. Aconteça o que acontecer, é meu filho".

No artigo "Gênero na infância: análise do filme 'La Vie em Rose' como instrumento pedagógico em educação sexual", as autoras Aline Anacleto e Ana Claudia Maia focam na questão da transexualidade de Ludovic e na forma, de acordo com elas, equivocada da família de lidar com a questão para defender a tese de que o filme poderia ser utilizado didaticamente de modo a sensibilizar "pais e mães, professores e professoras, adolescentes, estudantes etc." A partir dessa sensibilização, seria possível "trabalhar a dificuldade que é lidar com nossas próprias concepções estereotipadas de gênero". As autoras exploram questões apresentadas pelo filme que poderiam contribuir para a construção das angústias de Ludovic e da vivência de sua própria sexualidade como algo doloroso. Apontam os silêncios do pai, dos irmãos e da avó, o estigma que marca a diferença como indesejável e a confusão das famílias que "em sua 
maioria, vivem e reproduzem a crença de que a sexualidade humana é biológica, deixando de entendê-la como uma construção social, cultural e histórica” (ANACLETO; MAIA, 2009).

Não pretendemos questionar o valor dessa análise, sobretudo frente aos "clichês tradicionais" que, de acordo com Norbert Elias, "veiculam uma representação da família humana como configuração imutável e eternamente idêntica de seres humanos" (ELIAS, 2010). Mas, destacamos que a questão de uma possível transsexualidade de Ludovic permanece em aberto no filme. Em Minha Vida em Cor-de-Rosa, o efeito de fechamento (BORDWELL, 2005) do filme é construído pela aceitação dos pais e não se apresenta o futuro do filho. Não sabemos se Ludovic seguirá se vestindo com roupas femininas, não sabemos se passará a se identificar como menina, não sabemos se continuará sentindo atração por garotos, não sabemos se assumirá uma identidade transsexual. A única coisa que sabemos é que agora tem o apoio da família e que "agora tudo ficará bem".

Ainda que o filme seja identificado muitas vezes como um marco por tematizar a transsexualidade na infância, não há, em Minha Vida em Cor-de-rosa, uma tese clara sobre crianças transsexuais. Já sobre a forma como a família deveria se comportar, a norma é facilmente reconhecível: os pais devem aceitar os filhos como eles são, ainda que talvez não sejam jamais capazes de compreendê-los, como diz a psicóloga. Nesse processo de aceitação da individualidade, pai e mãe se apoiam e se controlam mutuamente.

\subsection{A Família Bélier}

Em A Família Bélier (LARTIGAU, 2014) somos levados a uma pequena cidade no interior da França, onde uma família produz e vende queijo. A mãe Gigi, o pai Rudolphe e o caçula adolescente Quentin são surdos de nascença, condição que não é compartilhada pela jovem filha Paula. Após participar de uma aula de canto, Paula descobre que tem potencial para se tornar uma ótima cantora e essa situação curiosa é o fio condutor pelo qual acompanhamos as relações familiares dos Bélier. O filme poderia ser descrito, a princípio, como um filme sobre a relação entre pais surdos e filhos não surdos. 
O filme começa com o nascimento de um bezerro na fazenda dos Bélier. As cenas iniciais apresentam a dinâmica da família, unida e trabalhadora e também a relação específica de Paula, que age como intérprete sempre que necessário. No consultório médico acompanhando os pais, Paula transmite as perguntas para um lado e as respostas para o outro:

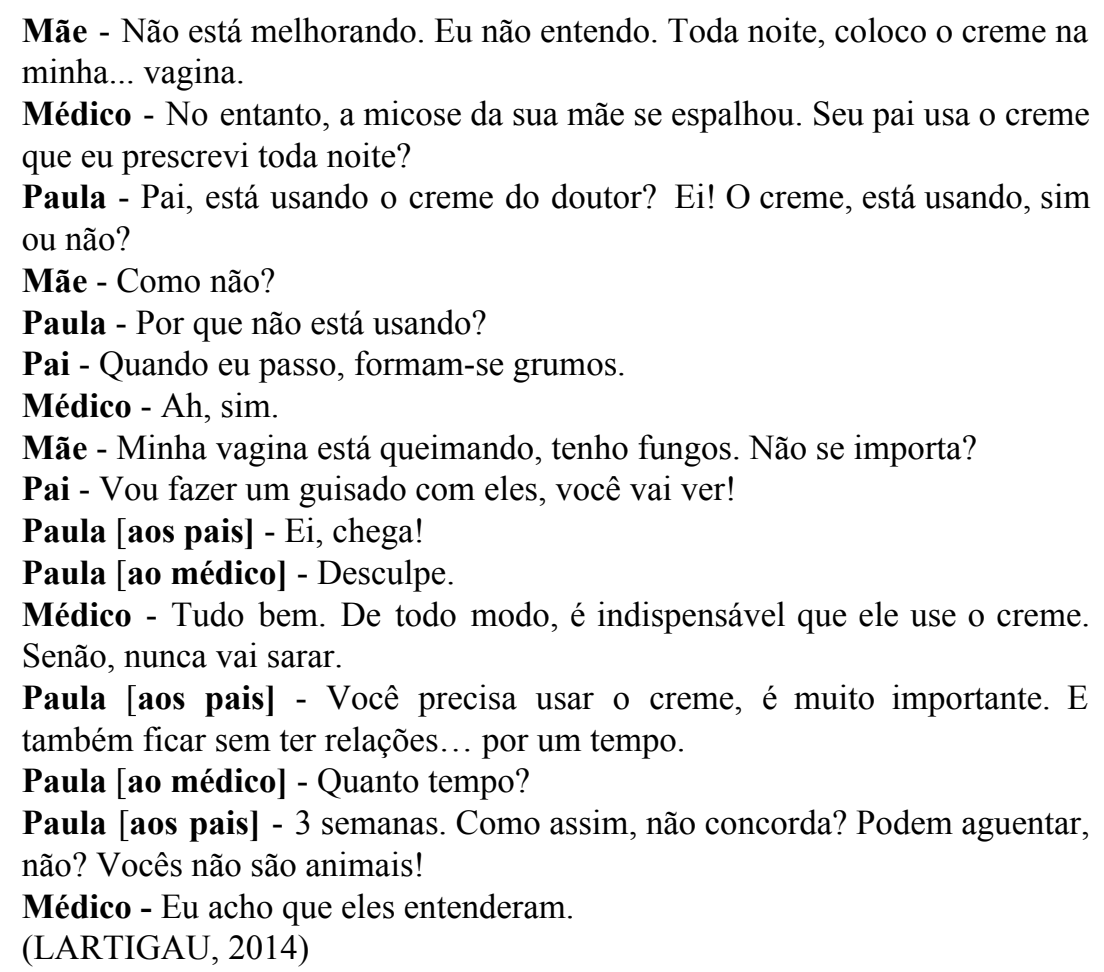

Depois, após encontrarem o prefeito em exercício, que pouco tem feito por eles, o pai decide concorrer para evitar um projeto de criação de um complexo industrial e um shopping que tomariam terrenos rurais e a área do bosque. A filha Paula se opõe.

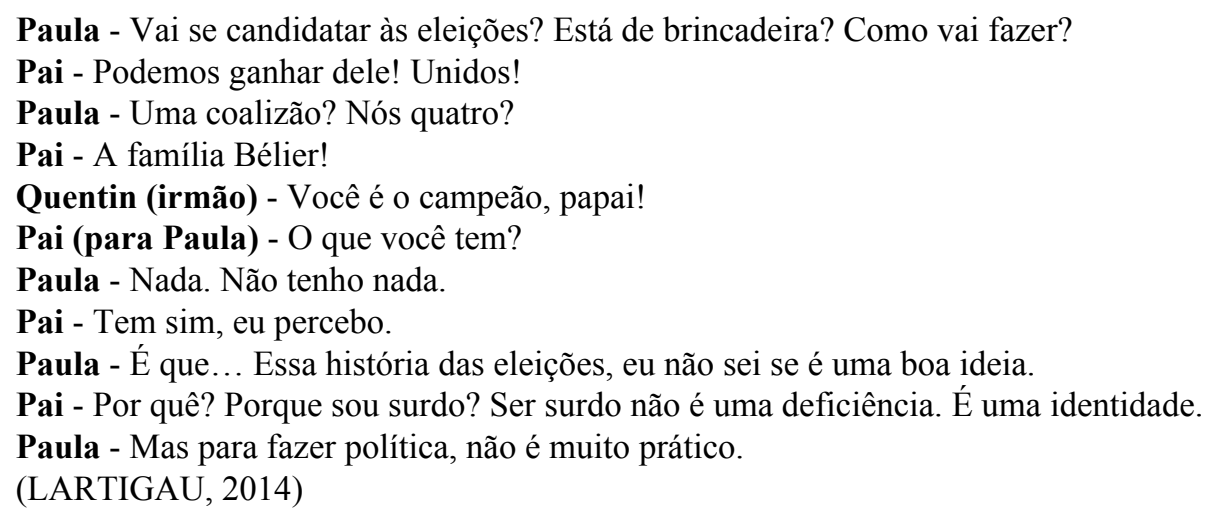


A sequência entre a cena de desconforto na situação de intérprete e a da hesitação em relação à candidatura do pai produzem um efeito de oposição entre a individualidade da filha e o projeto do pai, que demanda uma ação coletiva de toda a família e especialmente dela, como intérprete do grupo. Outras cenas, posteriores, reforçam essa construção apresentando os projetos coletivos da família, que na verdade são do pai, como conflitantes com o desenvolvimento individual de Paula. A individualidade da mãe não é desenvolvida no filme. O fato de ser mãe e de ser surda resume quase tudo que se sabe sobre ela ao longo de todo filme.

Paula, obrigada a frequentar alguma atividade extracurricular, escolhe participar do coral para se aproximar de Gabriel, um garoto por quem se interessa. No processo de testes e de divisão dos alunos de acordo com o tipo de voz, porém, o professor de canto, Sr. Thomasson, percebe o potencial de Paula e a escala para fazer um dueto com Gabriel. Mais do que isso, o professor revela que paula tem "uma pepita na garganta", tem um dom e uma oportunidade. Em três meses haverá um concurso que poderia lhe daria a oportunidade de estudar em Paris.

Sr. Thomasson (professor) - Você tem uma pepita na garganta, Srta. Bélier. E a pepita está brava! Quer aprender canto em Paris?

Paula - Eu?

Sr. Thomasson (professor)- Faz 10 anos que apresento alunos no concurso da Radio France. Faz 10 anos que fracasso, mas... com você e o Gabriel... Gabriel! Venha. Venha. Se aceitar, com você e o Gabriel... temos chance. O concurso é daqui a 3 meses, logo após o espetáculo.

Paula - 3 meses?

Sr. Thomasson (professor)- É pouco. Mas você consegue. Não há tempo a perder. Você tem um dom, Srta. Bélier.

(LARTIGAU, 2014)

Assim como em Billy Elliot, portanto, a revelação do dom é feita por um elemento externo à família, o professor de canto, que detém a autoridade para afirmar com legitimidade que a filha possui um talento não reconhecido pela família. Neste caso específico, esse dom é impossível de ser reconhecido pela família por conta da situação natural intransponível da surdez. Os pais não são capazes de reconhecer, a eles caberia aceitar e estimular. 
Figura 3 - Cena do filme A Familia Bélier em que o professor enuncia o dom de Paula.

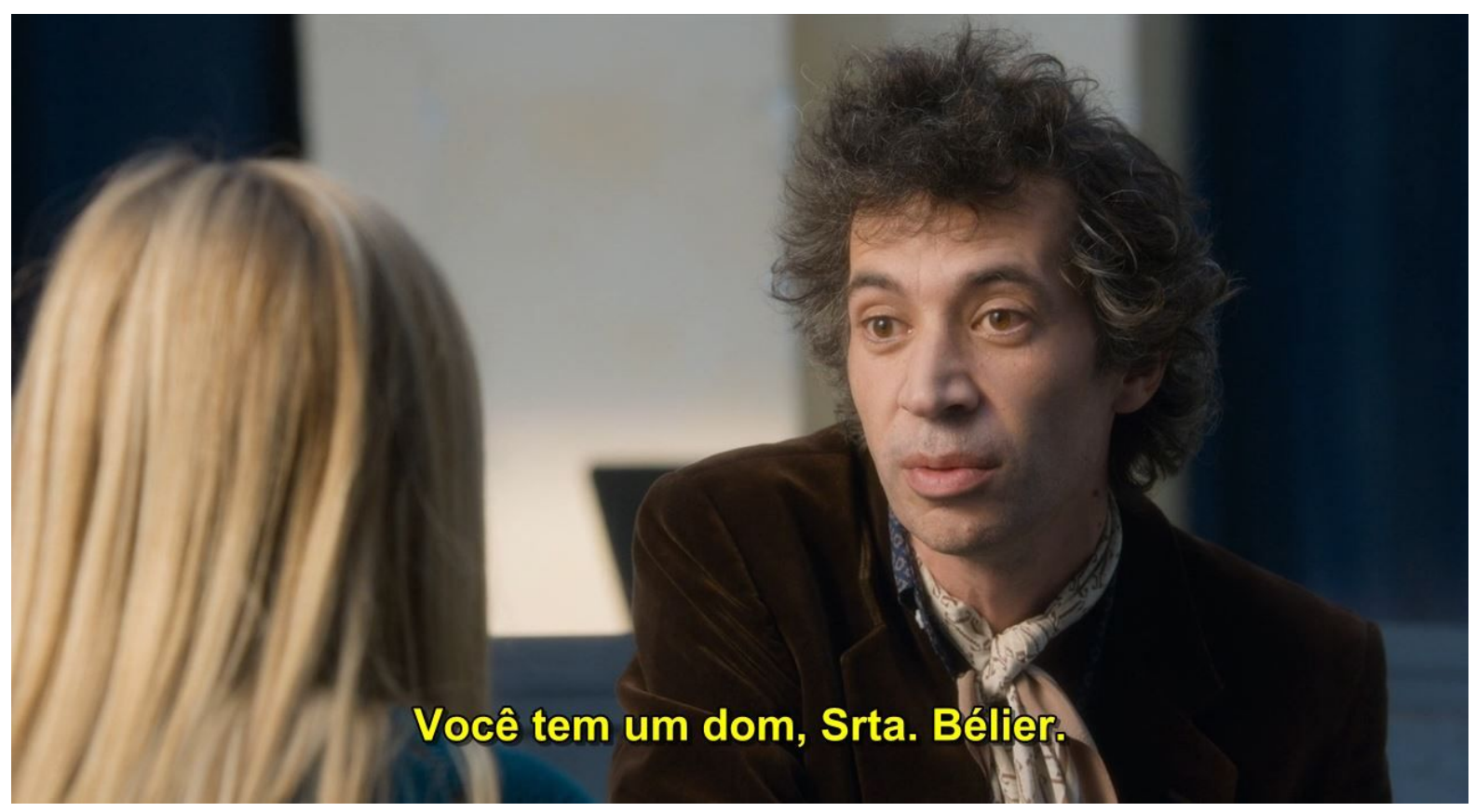

Fonte: print screen do filme $A$ Familia Bélier.

Paula tem medo da situação da família sem ela. A amiga Mathilde a incentiva dizendo que os pais são capazes de viver bem sem ela e que ela tem um dom, que isso é algo extraordinário que deve ser aproveitado.

Paula - Não posso ir à Paris.

Mathilde (amiga) - O quê? Por quê? É demais!

Paula - Com meus pais, o sítio...

Mathilde (amiga) - Pare com isso, já deu! São surdos, não incapazes. Como faziam antes de você nascer? Você quer ir para essa escola?

Paula - Acho que sim.

Mathilde (amiga) - Acha ou tem certeza?

Paula - Tenho certeza.

Mathilde (amiga) - Então preste esse concurso, depois você vê.

Paula - Sim, mas...

Mathilde (amiga) - Não, pare, chega! Não vai passar sua vida inteira aqui, comendo queijo. Você tem um dom. Sabe o que isso representa? É minha melhor amiga e tem um dom!

(LARTIGAU, 2014)

Ela assume um compromisso com o professor de praticar todo dia, mas não comunica à família. O projeto da candidatura do pai e das aulas de canto de Paula entram em conflito. A equipe de um canal de televisão chega à casa dos Bélier para filmar uma reportagem. Paula 
não pode estar nos dois lugares. Fica em casa de mau humor e diz que tinha um compromisso com o namorado. Consegue sair e chega atrasada na casa do professor. Todos ficam descontentes. Paula decide encarar a família e falar sobre as aulas de canto.

Paula - Tenho algo a dizer. É importante. Não, não estou grávida. Vou prestar o concurso para o coral da Radio France. É uma escola de canto em Paris. Meu professor acredita... que eu consigo passar. Sim, é em Paris mas... Não, eu não quero ir à Paris, mas... a escola fica em Paris. Sim, eu canto. Eu até... faço parte do coral do colégio. Há... 3 meses. É, 3 meses, mais ou menos. Não, ele não sabia. Porque eu temia que pensassem que estava abandonando vocês.

(LARTIGAU, 2014)

Os pais não reagem de forma compreensiva. A mãe apresenta a situação como um perigo para a filha, dizendo que tem medo dela sozinha em Paris. O pai reinterpreta como um medo deles, de ficarem sem a filha.

Mãe - Nossa filha quer virar cantora! Você se dá conta?!

Pai - E daí? Que ela cante!

Mãe - Ela está em perigo! Não é o presidente que vai salvá-la! O professor dela disse que ela tem uma voz linda.

Pai - E você já ouviu a voz dela, por acaso?

Mãe - Muito engraçado!

Pai - Ela mal começou. Talvez isso passe.

Mãe - E se ela for aceita? Imagine. Ela estará sozinha em Paris.

Pai - Não é disso que você tem medo. Você tem medo que nós fiquemos sozinhos aqui!

Mãe - Você sabe que ela é meu bebê.

Pai - Seu bebê? Ela até já menstrua! Pegaremos um ajudante para o sítio. Já devíamos ter feito isso há tempo.

(LARTIGAU, 2014)

A percepção de Paula sobre a resistência de seus pais ao novo projeto é contrastada com a percepção que Gabriel, o pretendente, faz dos pais dele. Na visão de Paula e Gabriel, uns que "não deixam o filho viver" e outros que "não se interessam". Dois excessos a serem evitados.

Paula - Por que você saiu do espetáculo?

Gabriel - Por acaso, você nunca fez besteira?

Paula - Não. É a primeira vez que mato aula, inclusive.

Gabriel - Pelo menos seus pais se interessam por você.

Paula - É, bem... Pelo menos seu pai deixa você viver.

Gabriel - Ou não dá a mínima.

(LARTIGAU, 2014) 
Depois que Paula enfrenta os pais, eles contratam uma assistente e têm dificuldades para se acostumar com a nova situação. Uma série de problemas se sucedem e são vistos, pelos pais, como relacionados ao comportamento da filha. O ápice desse conjunto de situações é um ataque alérgico que o irmão sofre. Quando Paula chega em casa, o irmão já está bem, dormindo, e a mãe está embriagada, tomando vinho sozinha.

Paula - Mãe? Mãe, o que está fazendo? Mas, mãe, você não pode ficar assim. Não fique triste.

Mãe - Eu não fui uma boa mãe para você. Tentei transmitir a você os valores da família... mas não podia dar certo entre nós. Eu sou surda. A culpa é minha. Fiz tudo errado.

Paula - Mas você não é uma mãe ruim. Pelo contrário. Você é a mãe que todos sonham ter.

Mãe - Então, por que quer ir à Paris?

Paula - Mãe...

Mãe - Era eu que deveria acompanhar você até o fim. O que foi que eu não vi?

Paula - Não é nada disso. Pelo contrário. É graças a você, ao papai, a tudo que me ensinaram... que eu consegui fazer essa escolha. Vocês me deram as chaves..

Mãe - Quando você nasceu e eu soube que ouvia bem... Você lembra? Eu chorei tanto! Nunca suportei quem ouvia bem. Era seu pai que me consolava. Ele dizia: "Não se preocupe... ela será surda na cabeça dela. Vamos criá-la como uma surda... e, quem sabe, com um pouco de sorte, ela não ouvirá nada!". E agora, você canta? Só faltaria você ser alérgica ao leite de vaca.

Paula - Então, estou condenada a vender queijo o resto da vida porque... não tenho a sorte de ser surda? É isso mesmo? É o que enxergam quando olham para mim?

Paula [ao pai]- E você? Não diz nada?

Pai - Para quê? Tudo bem, vá. Ficaremos muito bem nós dois.

(LARTIGAU, 2014)

Paula, devastada com a conversa, corre até a casa do professor e diz que irá desistir. O professor tenta acalmá-la em vão, dizendo que é normal ficar nervosa. Ela não muda de atitude e lhe diz: "Vou desistir, só isso". O professor então responde:

Thomasson (professor) - Não, não, não. Não é só isso. Você acha que só está desistindo. Na verdade, está cavando um buraco, deitando dentro... e jogando terra por cima. Posso lhe falar desse buraco, eu conheço bem. Estou enterrado no mesmo cemitério.

Paula - E daí? Eu faço o que quiser, é minha vida.

Thomasson (professor) - Tem certeza de que é sua vida?

Paula - Sim.

Thomasson (professor) - Paula, raciocine, por favor.

Paula - Vou desistir.

(LARTIGAU, 2014)

Deixar passar a oportunidade de explorar um dom é apresentado, pelo professor, como uma perda irreparável, é comparável à morte, à cavar a própria cova. Gabriel conversa 
com Paula e a convence a manter o dueto, mesmo sem participar para a seleção para a escola de Paris. Os dois se apresentam no show da escola e os pais de Paula vão assistir. As cenas de canto se intercalam com períodos de silêncio para reforçar a experiência dos pais, que estão presentes, mas que não escutam nada. Assim como em Billy Elliot, a dimensão do sacrifício é ressaltada. Estão lá exclusivamente pela filha.

Após o espetáculo, diz que Paula ainda pode prestar o concurso, no dia seguinte, às 10 horas da manhã. Depois, o professor aborda os pais de Paula, mas é ela que age como intérprete e não repassa as críticas:

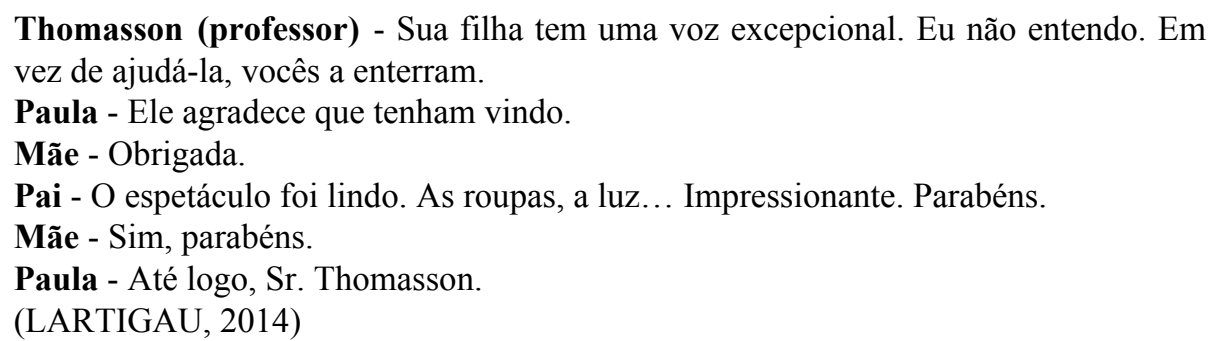

Chegando em casa, a filha se oferece para apagar todas as luzes e senta no jardim. O pai a acompanha e pede para que cante novamente a canção para que ele possa sentir a vibração colocando a mão na garganta dela. Todos dormem. Pela manhã o pai acorda a filha e decide levá-la. Toda a família vai junto.

Depois da conversa, segue uma agitação para conseguir chegar ao festival na hora marcada. Eles chegam à audição e ela canta Je vole, de Michel Sardou, que repete os seguintes versos: "Queridos pais, estou indo embora. Eu amo vocês, mas estou indo embora. Não terão mais filho esta noite. Não estou fugindo, estou voando. Entendam bem, estou voando."

O filme acaba com o professor de canto levando Paula. Ela pede para que ele pare o carro, desce e corre em direção da família para abraçá-los novamente. O pai diz apenas: "vá". A mãe concorda com a cabeça. Paula corre sorrindo.

O efeito de fechamento do filme (BORDWELL, 2005) é construído com a aceitação dos pais ao canto de Paula e o sucesso da filha na primeira etapa, que permitiria o ingresso na escola. Assim, ainda que a trama do filme seja bastante diferente das analisadas em Billy 
Elliot e Minha Vida em Cor-de-Rosa, o filme também ensina que os pais devem aceitar a individualidade dos filhos, mesmo se não sejam capazes de compreendê-la. A incompreensão dos pais em relação à individualidade da filha é levada ao extremo em Família Bélier, uma vez que a compreensão é apresentada como impossível. Não se trata de tentar compreender. Há uma barreira intransponível aqui. Os pais jamais serão capazes de escutar o canto de Paula para poder eles mesmos julgarem se ela tem potencial. Trata-se da defesa de uma confiança total por parte dos pais, que aceitam plenamente o diagnóstico do professor especialista na área e a vontade da filha em seguir esse caminho. Assim como nos filmes já analisados neste capítulo, Família Bélier também relaciona a ideia de que "os pais precisam compreender os filhos" com o enunciado de que "é preciso aceitar os filhos como eles são". Compreender, aqui, é aceitar. Neste filme, essa relação é tão forte que poderíamos inclusive apresentar o enunciado substituindo a compreensão pela aceitação: mais do que tentar compreendê-los, "os pais devem aceitar os filhos como eles são".

\subsection{Moana}

A animação Moana: um mar de aventuras (MUSKER; CLEMENTS, 2016) conta a história de uma família de chefes da aldeia de Motunui. Moana, única filha do atual chefe é preparada para liderança e instruída a nunca avançar no mar para além do recife.

A animação não situa geograficamente nem historicamente a narrativa. Sabemos apenas que o nome da ilha é Motunui. No entanto, as referências culturais toganas, samoanas e maoris revelam inspirações polinésias. O nome da personagem principal, Moana, é também título de um documentário ou docuficção de Robert J. Flaherty, realizado em 1926, apenas quatro anos após seu famoso Nanook. Robert, a esposa e as três filhas passaram um ano em Samoa filmando Moana (1926). O filme documental ensina que Moana significa "oceano profundo", mas, no documentário, o nome é de um rapaz que se prepara para um ritual de passagem para a vida adulta. As vestes preparadas das fibras de folhas para a ocasião, as tatuagens, a água doce de dentro do caule das plantas, o jeito de cozinhar, a forma de subir nos coqueiros são recriadas pela animação. 
A animação começa com a avó contando às crianças uma narrativa mitológica:

\begin{abstract}
No começo, só existia oceano. Até a Mãe Ilha emergir. Te Fiti. Seu coração guardava o maior poder já conhecido. Ele podia criar vida! E Te Fiti compartilhou o poder com o mundo. Mas com o tempo, alguns começaram a querer o coração de Te Fiti. Eles acreditavam que se conseguissem possuí-lo, o grande poder da criação seria deles. E um dia o mais ousado de todos viajou pelo vasto oceano para roubá-lo. Ele era um semideus do vento e do mar. Era um guerreiro. Um vigarista. Um metamorfo que podia mudar de forma com o poder de seu anzol mágico. E o nome dele... era Maui. Mas sem o coração, Te Fiti começou a desmoronar. Dando à luz uma terrível escuridão. Maui tentou escapar, mas foi confrontado por outro que procurava $\mathrm{o}$ coração. Te Ká! Um demônio de terra e fogo. Maui foi atingido enquanto voava... e nunca mais foi visto. E seu anzol mágico e o coração de Te Fiti foram perdidos para o mar. Onde até agora, mil anos depois, Te Ká e os demônios das profundezas ainda procuram o coração. Escondendo-se na escuridão que continuará a se espalhar, espantando nossos peixes, drenando a vida de ilha após ilha, até todos nós sermos devorados pelas garras sanguinárias da inescapável morte! Mas um dia, o coração será encontrado por alguém que viajará além do recife, encontrará Maui e o levará pelo grande oceano, para restaurar o coração de Te Fiti e salvar todos nós. (MUSKER; CLEMENTS, 2016)
\end{abstract}

Após a fala da avó, o pai, chefe da aldeia, chega e tenta amenizar as palavras de sua próprias mãe dizendo que "Ninguém vai além do recife. Estamos seguros aqui. Não há escuridão. Não há monstros.” A sequência entre a narrativa mitológica e a apresentação da personagem Moana e sua família, já indicam que ela provavelmente será a escolhida para recuperar o coração de Te Fiti e salvar a ilha, como de fato acontece. Também já se estabelece de partida o conflito entre pai e filha, uma vez que, de acordo com a narrativa contada pela avó, para salvar o coração de Te Fiti, a pessoa escolhida terá que viajar para além do recife.

Moana, ainda pequena, entra no mar e encontra a pedra verde, o coração de Te Fiti, que a protege magicamente, mas o pai a busca na praia sem ver o objeto e a alerta para não voltar ao oceano: "Você é a próxima grande Chefe do nosso povo. E fará coisas maravilhosas, minha pequenina. Claro que sim, mas primeiro, você precisa saber em que lugar você é destinada a estar." Há um conflito, portanto, entre aquilo que o pai considera que deveria ser o destino de Moana e aquilo que se impõe como seu verdadeiro destino por forças maiores do que o pai. Segue-se uma canção em que o pai apresenta o modo de vida da aldeia e argumenta que "A aldeia de Motunui é tudo de que precisa" e que Moana "deve achar a felicidade bem onde está". 
Logo após a argumentação do pai, Moana encontra a avó dançando no mar e ela apresenta um contraponto:

Gosto de dançar com a água com a corrente e as ondas. A água é travessa. Gosto de como ela se comporta mal. A aldeia pode pensar que sou louca ou dizer que me afastei bastante, mas quando descobrir do que gosta: essa é você. Você é filha de seu pai, teimosia e orgulho. Atente-se ao que ele diz, mas lembre-se: você pode ouvir uma voz interior. E se a voz começar a sussurrar para seguir a estrela mais distante, Moana, essa voz interior é quem você é. (MUSKER; CLEMENTS, 2016)

A avó apresenta diz que a identidade de Moana, sua verdadeira identidade, só será descoberta se ela escutar essa voz interior. Essa voz interior, por sua vez, está ligada ao desejo, a "descobrir o que você gosta". Você é sua voz interior, você é aquilo de que gosta, você é seu desejo. A analogia com o mar completa a mensagem da avó à neta: respeite seu pai, ouça o que diz, mas desobedeça se necessário.

O enunciado "você é sua voz interior, você é o que você gosta", pronunciado pela avó em Moana, permite ver uma relação estabelecida discursivamente entre identidade e interioridade, identidade e desejo e, consequentemente, entre desejo e vocação, que também se apresenta nos demais filmes. A pergunta dos avaliadores da academia de dança à Billy, em Billy Elliot, não foi sobre sobre a dedicação ou sobre os projetos, foi: “como se sente quando está dançando" (DALDRY, 2000).

Figura 4 - Cena do filme Moana em que a avó associa o desejo de navegar ao núcleo identitário de Moana.

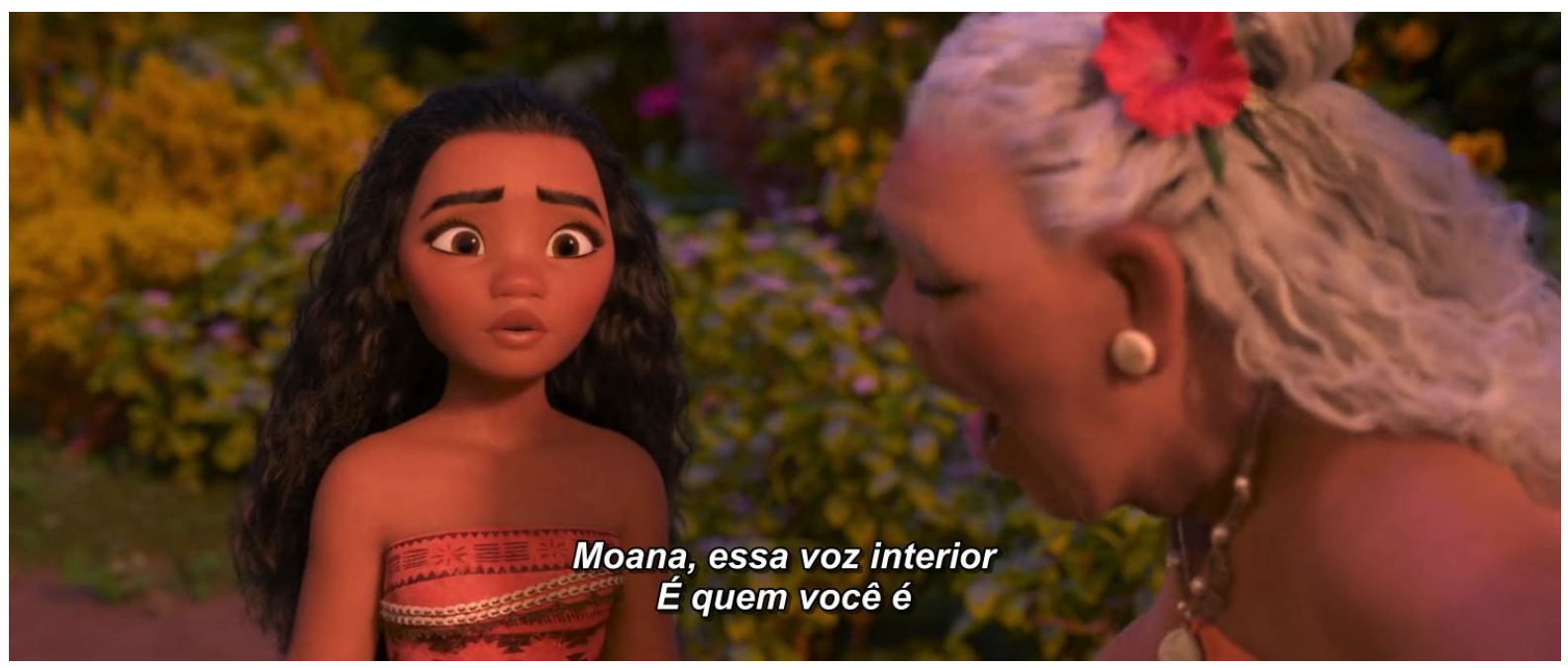

Fonte: print screen do filme Moana. 
O pai, chefe Tui, leva Moana ao alto da montanha e lhe mostra "um lugar sagrado, um lugar dos Chefes.” Ali, apresenta o destino da filha:

Haverá um tempo em que ficará de pé neste pico e erguerá uma pedra nesta montanha. Como eu fiz. Como meu pai fez. E o pai dele, e todo Chefe que já existiu. E nesse dia, quando erguer sua pedra, você vai elevar essa ilha bem alto. Você é o futuro do nosso povo, Moana. E eles não estão lá...[apontando para o oceano] eles estão bem aqui. É hora de ser a pessoa que precisam que você seja. (MUSKER; CLEMENTS, 2016)

O conflito, agora, é enunciado de outra forma, como uma tensão entre "ser quem você é, voz interior, desejo" e "ser a pessoa que precisam que você seja", entre uma identidade ligada à ascendência ou à comunidade e uma identidade ligada ao desejo. Essa nova enunciação do problema apresenta a decisão de ficar ou partir como uma decisão de busca identitária e apresenta as alternativas como mutuamente excludentes. A identidade não está lá, a identidade está aqui.

No entanto, apresenta a identidade familiar ou comunitária como uma falta de liberdade, "ser a pessoa que precisam". O pai coloca o problema da ilha como responsabilidade da filha, de modo que negar essa identidade seria uma atitude egoísta que levaria à ruína da comunidade. Colocado nesses termos, o conflito só poderá ser solucionado quando Moana descobrir que sair da ilha não é apenas um desejo individual, mas é exatamente a ação necessária para salvar seu povo.

Moana tenta se adequar ao papel de liderança que lhe aguarda. Guia o povo, dá conselhos, soluciona problemas, mas a situação da ilha só piora. O côcos estão secos, não há peixes. Moana propõe: "E se pescarmos além do recife?" O pai novamente nega: "Temos uma regra. Regra antiga, de quando havia peixes. Uma regra que nos mantêm seguros, em vez de colocar nosso povo em perigo, para que você possa correr de volta para água. Toda vez que acho que superou isso... Ninguém vai além do recife!" $O$ pai considera que a sugestão da filha está associada ao desejo de navegar. A mãe de Moana procura a filha e tenta mediar a situação, explicando as intenções do pai.

Mãe - Não é como se tivesse dito na frente do seu pai, de pé, em um barco.

Moana - Eu não disse para irmos além do recife porque eu quero estar no oceano.

Mãe - Mas ainda assim, você quer. Ele é duro com você...

Moana - Porque ele não me entende.

Mãe - Porque ele era você. Atraído pelo oceano. Nadando pela costa. Ele pegou uma canoa, Moana. Ele cruzou o recife. E achou um mar imperdoável. Ondas do tamanho 
de montanhas. O melhor amigo dele implorou para estar naquele barco. Seu pai não pôde salvá-lo. Ele espera poder te salvar. Às vezes, quem desejamos que fôssemos, o que desejamos poder fazer... Simplesmente não é nosso destino.

(MUSKER; CLEMENTS, 2016)

O pai, de acordo com a mãe, quer proteger a filha daquilo que sofreu ao tentar seguir seu próprio desejo. A mãe, cuja identidade no filme está exclusivamente associada ao fato de ser mãe de Moana, sem nenhuma construção de individualidade, diz que às vezes destino e desejo não se encontram. $\mathrm{O}$ fato desse desencontro ser pronunciado pela mãe sem individualidade, por um lado, realça a dimensão de sacrifício da própria mãe, a personagem sem desejos. Por outro lado, complexifica a relação entre desejo e destino ou entre desejo e identidade. Não se trata simplesmente de ser aquilo que desejamos, há fatores externos que podem impedir. Moana canta:

\begin{abstract}
Estou olhando para a beira da água desde que consigo me lembrar, sem nunca saber o porquê. Eu queria ser a filha perfeita, mas eu retorno para a água, não importa o quanto eu tente. (...) Aqui é tudo projetado. Eu sei que todos nesta ilha têm um papel nesta ilha. Talvez eu possa cumprir o meu. Posso liderar com orgulho. Posso nos tornar fortes. Ficarei satisfeita se eu fizer isso. Mas uma voz aqui dentro canta uma música diferente. O que há de errado comigo? (MUSKER; CLEMENTS, 2016)
\end{abstract}

Assim como Billy tentando lutar boxe em Billy Elliot, Ludovic tentando se "vestir normal" (palavras dele) em Minha Vida em Cor-de-rosa e Paula tentando participar do projeto político da família em Família Bélier, Moana é construída discursivamente como uma personagem que quer ser uma boa filha e que, para isso, tenta se adequar às expectativas dos pais, mas não consegue.

Em Moana, ao contrário dos outros, porém, a filha não é incompreendida por uma incapacidade dos pais de compreenderem a busca identitária da filha ou por não terem o sentido ou a formação necessárias para reconhecer um potencial. Neste filme, o pai compreende o desejo da filha, porque teve um desejo similar, mas quer privá-la da frustração e dos perigos que essa busca pode trazer.

Moana tenta atravessar os recifes, mas fracassa. A avó a encontra na praia e garante cumplicidade.

Avó - Você ouviu todas as histórias do nosso povo. Exceto uma...

Moana - Que lugar é este?

Avó - Você realmente acha que nossos ancestrais ficaram dentro do recife? 
Moana - O que tem lá dentro?

Avó - A resposta para a pergunta que você fica fazendo a si mesma: 'Quem você está destinada a ser?'. Vá lá dentro, toque o tambor e descubra.

(MUSKER; CLEMENTS, 2016)

A questão da identidade é projetada para o futuro: "quem você está destinada a ser". Destino e identidade se reencontram. Não é uma predestinação das ações, mas uma identidade predestinada. Há uma identidade verdadeira que espera ser descoberta. Realizar-se é descobrir essa identidade. Moana está destinada a ser alguém, não a fazer. A ação é apenas o meio que a levará à realização identitária. Novamente, as escolhas giram em torno de um autoconhecimento, do conhecimento do próprio desejo.

\section{Figura 5 - Cena do filme Moana em que a avó pergunta a Moana quem ela está destinada a ser, supondo uma essência predeterminada.}

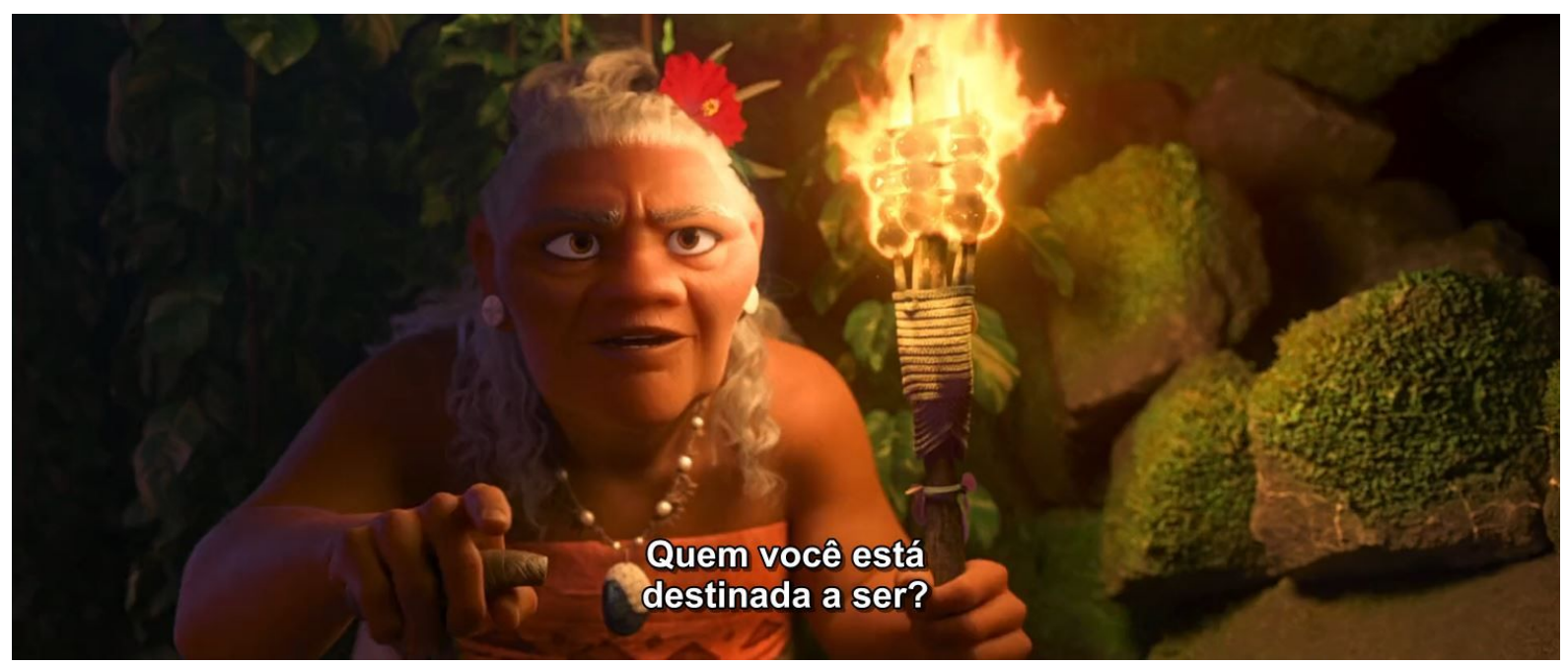

Fonte: print screen do filme Moana.

Moana toca o tambor e descobre que seu povo era navegador e que essas histórias têm sido omitidas. Uma canção mostra a verdadeira identidade de seu povo: "Lemos o vento e o céu. Quando o sol está forte, navegamos ao longo do mar. Na brisa do oceano, de noite, nomeamos cada estrela. Sabemos onde estamos. Nós sabemos quem somos. Quem somos”.

Moana sai da caverna gritando: “Éramos exploradores! Éramos exploradores!” E pergunta à avó "Por que paramos?". A avó, então, explica a maldição e a profecia, entrega-lhe a pedra verde, o coração de Te Ká, e revela que Moana é a escolhida: 
Maui. Quando ele roubou da Ilha Mãe, a escuridão caiu. Te Ká despertou. Monstros atacaram e barcos pararam de retornar. Para proteger nosso povo, os Chefes anciãos proibiram a excursão e agora esquecemos quem somos. E a escuridão continuou se espalhando, espantando nossos peixes, drenando a vida de ilha após ilha. Nossa ilha. Mas um dia, alguém viajará para além do recife, encontrará Maui e o retirará do grande oceano, para restaurar o coração de Te Fiti. Eu estava lá naquele dia. O oceano escolheu você. (MUSKER; CLEMENTS, 2016)

Se, nos outros filmes contemporâneos, esse desejo ou dom, é validado por um especialista externo à família para que haja a aceitação da individualidade incompreendida da criança pelos pais, em Moana, ela é validada pelos deuses e pelas características históricas do povo. Seu povo é um povo do mar e Moana, “oceano profundo", é a escolhida pelos deuses para cumprir a profecia.

Moana interrompe a reunião do conselho, anuncia que são exploradores, que podem navegar. O pai se irrita e diz que deveria ter queimando os barcos, mas antes que possa tomar qualquer atitude, é chamado para ver a avó, que está deitada na cama. A avó chama Moana e lhe diz para partir. Enquanto todos cuidam da avó, ela sai para enfrentar o oceano. A mãe percebe e não impede, ao contrário, abraça Moana em silêncio. A aventura se desenvolve. Moana encontra Maui, eles recuperam o anzol, enfrentam Te Ká, devolvem o coração e acabam com a maldição. Moana retorna para casa para a cena final:

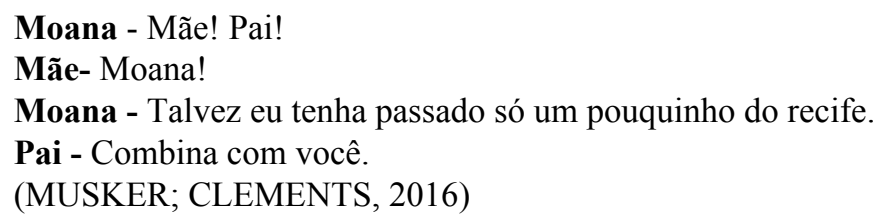

Pai, mãe e filha se abraçam. Os outros moradores da aldeia vêm recebê-la. Agora todos navegam felizes. Moana ensina o pai a encontrar as correntes com o remos e a mãe a dar nós. Moana sobe ao lugar sagrado dos chefes e, sobre as pedras de seus antepassados, coloca uma concha. Moana e o povo encontraram sua verdadeira identidade.

O efeito de fechamento (BORDWELL, 2005) de Moana, com Moana se tornando quem ela está destinada a ser, navegando para além dos recifes contra a vontade do pai, salvando a ilha, depois retornando para a família onde é acolhida com felicidade por um pai 
que diz que "combina com você", reforça também a mensagem de que os pais devem aceitar os filhos como eles são.

Em todos os filmes contemporâneos analisados, a ligação entre o futuro das crianças protagonistas e o os acontecimentos exteriores ao lar são muito fracos ou quase inexistentes. Essas relações aparecem apenas como hostilidade do meio, que se impõem como empecilhos à busca de uma essência, que, por sua vez, deve ser apoiada pela família. Billy Elliot chega a situar historicamente alguns problemas da família, mas o futuro de Billy não é descrito em função dessas questões. Em Moana, uma exceção, futuro individual e comunitário estão atrelados, mas apenas pela situação de chefe de aldeia que Moana está destinada a ocupar. Não é a identidade individual de Moana que é narrada a partir de causas sociais, históricas, mas o inverso: é a história do povo de sua aldeia que segue o modelo de uma busca identitária análoga à de Moana. Assim como Moana, o povo deve se tornar aquilo que está destinado a ser, pela ação individual da personagem. Deve ser tornar, no futuro, algo ao qual está predestinado, algo, portanto, já predeterminado, mas não revelado. A história de Moana é a história da descoberta da essência de um povo e da essência de uma pessoa.

O modo de endereçamento de Moana, mais ajustado às exigências de uma equidade entre os gêneros e a pautas levantadas pelos movimentos feministas, garantiu a Moana uma série de elogios da crítica. A antropóloga e historiadora Lilia Moritz Schwarz descreve aquilo que considera alguns avanços de Moana em relação aos estereótipos produzidos por outras animações da Disney:

\footnotetext{
Moana começa e termina o filme sem namorado. Além disso, não precisa romper com a família para se afirmar. Também não é obrigada a transformar o semideus, Maui, em humano (e assim se casar com ele). Tampouco ocorre o oposto: ela não abre mão do seu mundo para entrar no dele. Ao contrário, nesse jogo de inversões, até a divindade é pra lá de imperfeita: é vaidoso, muito centrado em si, e, ademais, complexado com as besteiras que fez no passado. Para completar a figura, é um pouco gordinho (ao menos na métrica severa da Disney, que prefere príncipes atléticos), com cabelos mechados que lhes caem nos olhos, haja sol ou haja chuva. (SCHWARCZ, 2017)
}

Mais ao final do artigo ainda completa que:

Seria pedir demais dos estúdios Disney que problematizasse a chegada do capitalismo nessas paragens. Mesmo assim, gostaria de brindar a coragem do filme. $\mathrm{Na}$ trama, tudo parece seguir a coerência "da ilha": um local fechado e dominado por seus próprios parâmetros, desafios e receios. Não só a narrativa reproduz músicas, tatuagens e termos locais, como guarda a estrutura dos mitos. Além do mais, a 
heroína é uma mulher jovem; a divindade se expressa sob a forma de mulher, e a mentora, mais velha e sábia (a despeito de por vezes ser tomada como louca) é sua avó. Portanto, o parentesco é matrilinear e a descendência toda feminina. (SCHWARCZ, 2017)

De acordo com a autora, essas mudanças progressistas de Moana não se devem a uma ousadia da indústria cinematográfica, mas à adaptação aos novos arranjos familiares:

Esse é, pois, um desenho antenado com os novos arranjos familiares. Por isso, à sua maneira, ele reage e traduz a realidade de mães que têm decidido conceber e criar seus filhos por conta própria, sem a presença de um marido, de uma família, ou até mesmo de um pai titular. Também diz respeito aos núcleos familiares constituídos apenas por mulheres. Por fim, dialoga com esposas, companheiras, namoradas, e o que for, que não têm como objetivo último na vida encontrar seu príncipe encantado e ponto final. (SCHWARCZ, 2017)

Ainda que, em relação às princesas de animações anteriores, essas mudanças sejam perceptíveis e inegáveis, sobretudo nas relações de amizade de Moana e na ausência de um par romântico como necessário, quando observamos as relações familiares de Moana, vemos uma família conjugal, monogâmica, heterossexual, com uma única filha e contra aquilo que acredita ser o melhor caminho para a filha, deve aceitar o desenvolvimento da individualidade conflitante de Moana na busca por sua própria essência.

Se, por um lado, a personagem mulher é individualizada e não é construída em relação a um par romântico masculino ou ao objetivo de encontrar um companheiro, por outro lado, a mãe de Moana não possui individualidade nenhuma. A construção da imagem da mãe dificilmente seria lida como um elemento progressista. A família descrita em Moana e o modo como ensinam os pais a aceitarem os filhos não apresenta nenhuma ruptura radical em relação às regularidades que observamos no discurso sobre família nos filmes contemporâneos. Que o modo de endereçamento (ELLSWORTH, 2001) de Moana esteja mais centrado em uma multiplicidade de arranjos familiar como supõe Schwarcz, isso gera poucas alterações na forma como a família é construída e instruída. A norma que se constrói em relação a como os pais devem tratar os filhos é a mesma. 


\subsection{O Grande Dia}

O documentário francês $O$ Grande Dia (PLISSON, 2015) acompanha momentos decisivos na vida de quatro pessoas: Nidhi Jha (16 anos), que estuda para disputar uma vaga em um curso preparatório para estudantes de engenharia; Albert Gonzalez Monteagudo (11 anos), que treina para se tornar boxeador em Cuba; Delgermurun 'Deegii' Batjargal (11 anos), que se prepara para uma audição que pode lhe garantir uma vaga em uma reconhecida escola de contorcionismo na Mongólia; e Tom Ssekabira (19 anos), que faz um curso para se tornar guarda florestal em Uganda. Como o próprio título indica, todos precisam passar por alguma prova para que possam prosseguir em seus objetivos.

O filme começa com a seguinte frase, que, de partida, anuncia a ligação entre os quatro casos que irá narrar: "Aqui ou em outros lugares, com a esperança de ter uma vida melhor, meninos e meninas lutam pelos seus sonhos, pelas suas paixões”.

O primeiro menino apresentado é Albert, um menino de 11 anos que dispara socos no ar em um bairro de casas simples de Havana, Cuba. A mãe, Iraida, o chama e ele entra em casa para se banhar com a água de um tonel, ao lado da mãe, que reclama do gás enquanto liga o fogão para esquentar o leite. Chega, Roberto, amigo de Albert. A mãe anuncia que, como as notas do filho estão melhorando, ela vai deixá-lo treinar. Albert e amigo comemoram, mas a mãe alerta: "Mas não pode me decepcionar. Não pode me decepcionar. Lembre que o seu treinador é exigente com as suas notas".

Depois saltamos para Oulan-Bator, na Mongólia, onde a mãe de Deegii acorda gentilmente a filha de 11 anos. "Querida, acorde. Já são 7h. Você tem treinamento. VocÊ precisa treinar, não é?” A casa de Deegii também é simples, mas maior que a de Alberto. Nenhuma das duas tem água encanada. Deegii escova os dentes com a água de um recipiente. Assim como Alberto, Deegii vai a pé para o treino sem a companhia de um adulto. A mãe diz para a filha ter cuidado e pede que traga água na volta. Ela caminha até chegar ao local, uma grande tenda, o Circo Khulan, de onde pratica manobras de contorcionismo em meio a outras garotas, todas orientadas pela professora Ariunaa, que corrige os movimentos exigindo precisão. 
Vamos agora para o Parque Nacional "Queen Elizabeth”, em Uganda, onde Tom, um jovem de 19 anos, observa a paisagem e um livro com fotos de diversos pássaros. Dois colegas o chamam para voltar à aula, na escola nacional de guardas florestais: "Vamos chegar atrasados na aula de falar em público". Tom, no entanto, argumenta que ainda não está preparado e pede que Priscilla faça perguntas sobre uma águia. Ele responde e é elogiado pelos amigos: "Você é inteligente. Temos orgulho de você. Você vai passar." De volta à escola, a professora lembra a todos que o exame será oral e que, por isso, precisam treinar como falar em público. Após a apresentação de alguns alunos, a professora orienta para que não esqueçam da linguagem corporal e pergunta: "Onde está a paixão de vocês? E o amor pela natureza?" Na vez de Tom, ele conta, de forma mais articulada que os anteriores que quer se tornar um guarda florestal para ter um emprego e estudar chimpanzés.

Seguimos para Benares, na Índia, onde Nidhi, uma menina de 16 anos, estuda um livro de geometria coordenada, em inglês, e faz anotações em seu caderno, nas escadas de um templo, à beira de um rio, enquanto outras pessoas se banham e meditam. A avó da garota se aproxima, reforça o vermelho do ponto bindi, na testa de Nidhi e pergunta se a neta já acabou a lição. Ela diz que ainda não, mas aceita voltar para casa. Depois, Nidhi vai sozinha de bicicleta até um Cyber Café, onde busca, pelo computador, a ficha de inscrição para o teste de admissão da Super 30 - Escola de Matemática Ramanujan e a imprime. Chegando em sua casa, igualmente simples, é interrogada pelo pai sobre onde estava e explica sobre o teste e sobre o curso:

Nidhi - É um curso gratuito em Patna que prepara 30 jovens para o concurso da Politécnica.

Pai - E por que quer passar no concurso?

Nidhi - Eu quero ser engenheira.

Pai - Vai ter que morar sozinha em Patna. Como vai se virar?

Nidhi - Vou ficar com outros alunos.

Pai - Será que você vai passar?

Nidhi - Vamos ver. Tem muitos candidatos, mas eu quero tentar.

Pai - Isso é bom. Se conseguir, vai ser ótimo para você.

Nidhi - Isso pode mudar a vida da nossa família.

Pai - Vamos ver...

(PLISSON, 2015) 
Em casa, o pai de Deegii diz para a filha ter cuidado para não se machucar. A mãe diz para a filha fazer o dever de casa. A filha argumenta que a audição é em três dias e que precisa treinar, mas não contesta as ordens.

De volta ao centro de treinamento, quando Albert treina, todos param para assisti-lo e torcer. Ele é diferenciado. Após o treino, Albert limpa o ginásio e é chamado pelo treinador Yosvani:

Treinador - Já limpou o ginásio?

Albert - Já professor.

Treinador - Bom, mandei chamar você, porque inscrevi você em um concurso que vão fazer entre os melhores atletas da região para ver quem vai ser selecionado para a Academia de Boxe de Havana.

Albert - É verdade, professor?

Treinador - É. Você tem condições, mas vai ter que se esforçar mais um pouco. Seus adversário são lutadores que nunca faltaram nos treinos e que são melhores do que você ou iguais a você. Você vai ter que mostrar a sua qualidade. Sabe disso, não?

Albert - Sei.

Treinador - Eu acredito em você. Eu inscrevi você porque quero que você seja o melhor. Você não pode me decepcionar. Não me decepcione.

(PLISSON, 2015)

No dormitório da escola, Tom conversa com um amigo:

Tom - Está com saudade dos seus pais?

Amigo - É claro que estou. Eu não vejo meus pais faz 4 meses. Eu quero conseguir esse diploma e voltar para casa. Aí, meus pais vão ficar felizes. Porque eles se esforçaram para pagar o curso para mim. E você?

Tom - Eu sei que eles devem estar com saudade de mim. Estou com muita saudade deles. Da minha mãe, do meu pai... Sei que eles também estão com saudade de nós. Devem estar com muita saudade. Sei que vamos ser os melhores. Acredito nisso. Mas o governo vai escolher os melhores entre os melhores.

Amigo - É claro.

Tom - Temos que rezar muito para o governo nos escolher. E temos que estudar muito. Nós estamos estudando e vamos passar.

(PLISSON, 2015)

Assim, passados 30 minutos de filme, já está determinado um padrão: os quatro casos narrados são de pessoas que são boas no que fazem, que têm o apoio da família, ainda que com a condição de não tirar notas baixas, e que precisam passar por algum grande teste para poderem seguir seus objetivos: um concurso de boxe que permite o ingresso na Academia de Boxe de Havana; uma audição que permite a admissão na Escola de Circo de Singapura; uma prova que permite o ingresso em uma escola preparatória para o teste de admissão da 
Politécnica; um teste oral que selecionará quais alunos estão aptos a se tornarem guardas florestais.

As cenas seguintes são de todos treinando muito. Nishi estudando, Albert pulando corda e batendo em um saco de pancadas, Neegii fazendo exercícios e escolhendo a roupa para o dia da audição e Tom participando ativamente de todas as atividades com empenho máximo.

Neegii é criticada pela professora, que a alerta: "Você está muito lenta. Posicione os braços corretamente. (...) Você nunca vai ser escolhida. A audição vai ser muito difícil. Os jurados observam tudo. (...) Assim você não vai ser selecionada”. Em casa, no entanto, recebe apoio:

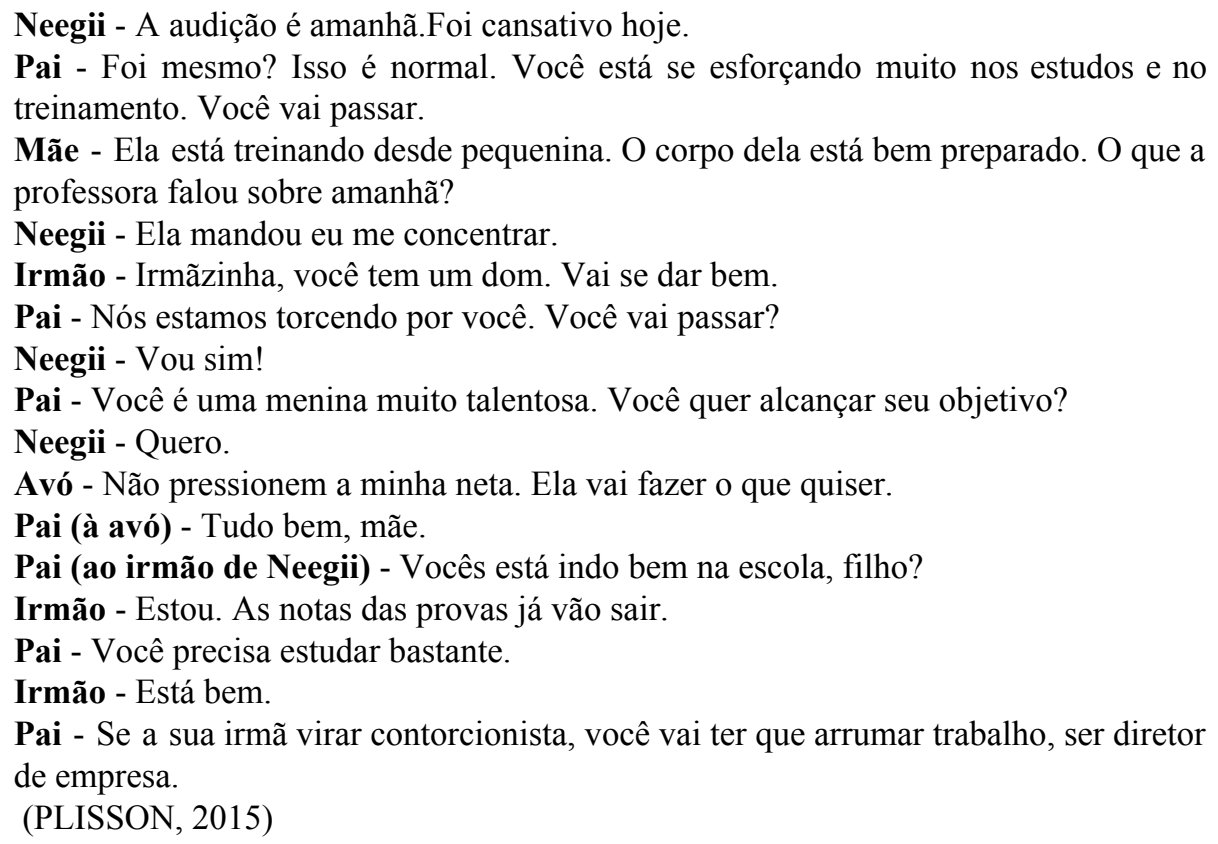

Albert também tem o desempenho cobrado pelo treinador:

Não exponha a cabeça, cara! Sabe o que é isso? Você está comendo bola. Mãos para cima! Você acha que vai ganhar assim? Tem que treinar duro. Quer levar porrada? (...) Que socos são esses? Reaja! Reaja! Você quer ganhar ou não? Acha que vai vencer assim? Assim você não tem chance, cara. Vai, luta! (...) Acha que vai entrar na Academia assim? Quer uma educação melhor? Trabalhe! (PLISSON, 2015)

E, igualmente, recebe apoio de Roberto, seu amigo, quando, após o treino, senta na praia para chorar. 
Roberto - O Yosvani abusa da gente. Albert? Não esquenta com isso. A vida é assim mesmo.

Albert - O professor falou que não vai ser fácil.

Roberto - Não liga para ele. Sabe que eu sou seu treinador. Que tristeza é essa? Estamos num lugar lindo. Vamos lá, campeão. Vamos lá...

(PLISSON, 2015)

Na casa de Nidhi, o momento de preencher a inscrição se transforma quase em uma cerimônia, com toda família presente. Preenche a profissão do pai: "motorista de Tuk-tuk". O pai diz que se passar, ela sentirá saudade de casa e que "será a primeira a sair de casa".

Ainda que seja um percurso escolhido pelas próprias crianças e que sejam reconhecidas como potencialmente boas nessa área, o sucesso não é garantido e o percurso não é realizado sem pressão, seja dos treinadores, seja dos pais. O sucesso pessoal dos filhos, no caminho que eles escolheram, acarretaria, nos quatro casos, em melhorias significativas para todas as famílias. A liberdade da criança de encontrar seu próprio caminho não a exime da cobrança de que seja bem sucedida.

Pais e amigos, aparecem aqui como co-treinadores. De acordo com Singly, como forma de se relacionar com essa suposta natureza individual da criança em desenvolvimento espontâneo, os pais são instigados a se converterem em treinadores:

\begin{abstract}
Segundo o ideal das sociedades individualistas, as famílias proporcionam condições para que cada um, pequeno ou grande, possa tornar-se e continuar ele próprio, por um lado, graças à ajuda personalizada de próximos e, por outro graças a um ambiente que permita criar o seu mundo pessoal. A independência deixada a cada um não basta para definir a atração da família moderna, como o faz supor o modelo da relação pura proposto por Anthony Giddens. De facto, os próximos não se devem limitar a deixar em paz o indivíduo (pequeno ou grande) quando é preciso, devem, noutros momentos igualmente decisivos, olhá-lo, escutá-lo, aconselhá-lo, eventualmente contradizê-lo e criticá-lo. O cônjuge e o pai conseguem desempenhar esta nova missão tornando-se, de certo modo, "treinadores". Os pais interpretam o que a criança exprime sem terem sempre consciência do que ela quer dizer. Eles tranquilizam, apoiam nos momentos difíceis. Em parte, o cônjuge executa o mesmo trabalho de conforto identitário e de interpretação. No entanto, ao contrário do pai, ele espera alguma reciprocidade neste trabalho. (SINGLY, 2011, p. 93-4)
\end{abstract}

Nos outros filmes analisados, o clímax ou o fim das narrativas é anterior a um tempo de um possível treinamento. Os filmes se concentram na descoberta e na aceitação pela família e terminam com a aceitação por uma escola especializada. O momento dos pais que já aceitaram essa individualidade, se relacionando com os filhos, estimulando, interpretando e 
eventualmente confrontando, não aparece nos filmes contemporâneos analisados até aqui. A família de Paula (A Família Bélier), de Billy (Billy Elliot), de Ludovic (Minha Vida em Cor-de-Rosa) e de Moana (Moana) aceitam a individualidade dos filhos após diversos conflitos e os filmes não chegam a mostrar um período em que os pais se convertam em treinadores ou co-treinadores dos filhos. À exceção de Billy Elliot, todos acabam com a aceitação da família. Billy Elliot chega a apresentar o sucesso de Billy adulto, mas é um salto temporal do momento de aceitação e ingresso na academia para o momento do sucesso.

Uma especificidade de $O$ Grande Dia, portanto, é que o filme já parte de uma situação de aceitação das famílias em relação ao projeto dos filhos e apresenta essa relação de apoio e pressão, que caracteriza igualmente o comportamento dos pais, amigos e treinadores.

Uganda, Cuba, Índia e Mongólia. Acompanhamos a vida de quatro pessoas em contextos sociais, culturais, políticos e econômicos bastante distintos. No entanto, nada disso aparece na narrativa. As especificidades de cada região, com sua história e cultura, certamente são determinantes para a escolha do objetivo buscado: o boxe em Cuba, o contorcionismo na Mongólia, a guarda florestal em Uganda e a engenharia na Índia. No entanto, a motivação das escolhas não é nunca referida a características locais. O percurso de cada personagem, igualmente, é descrito apenas em relação aos dramas familiares, sem relacioná-los aos diferentes contextos. Se nos detemos em descrever o que não aparece no filme não é para realizar uma crítica, mas apenas para realçar o contraste que o filme constrói entre a escolha de personagens tão distintos, por um lado, e a regularidade da narrativa referida exclusivamente às questões individuais e familiares, por outro.

O grande dia dos três primeiros personagens é um pouco diferente do de Tom. Além de mais velho que os outros, o momento que acompanhamos, no caso de Tom, é o de uma comissão de especialistas avaliando se ele já está pronto para exercer a função após passar dois anos com outros jovens, longe de casa, em uma escola especializada na formação de guardas florestais. Já nos três outros casos, a prova não é para concluir um curso ou uma etapa, mas, ao contrário, uma apresentação a uma comissão de especialistas que devem avaliar se vale a pena investir no desenvolvimento das habilidades dessa pessoa nessa área, ou seja, é um teste para começar um treinamento. Os dias decisivos de Nidhi, de Albert e de Deegii, portanto, são bastante similares ao de Billy, sendo avaliado para a Escola Real de 
Balé de Londres, em Billy Elliot (DALDRY, 2001) e ao de Paula sendo avaliada para a escola de canto em Paris, em A Família Bélier (LARTIGAU, 2014). Tom, Nidhi e Albert são bem sucedidos no grande dia que acompanhamos, Neegii, falha nesse teste.

Após a conquista, o pai de Albert diz que se sente realizado no filho, vendo o filho conseguir algo que ele não conseguiu, ter algo que ele não teve.

Pai de Albert (para Albert) - Filho, escuta. Quando eu tinha a sua idade, eu queria ter ido para uma escola assim para virar um grande boxeador, um campeão olímpico, um campeão mundial. Eu passava pela escola e via os moleques treinando e estudando, mas eu ficava de fora. E agora você transformou o meu sonho em realidade. Parabéns. Meu Deus... Como eu estou orgulhoso de você!

Pai de Albert (para as câmeras) - Na verdade, eu queria ser como ele, mas nunca consegui. Eu me sentiria realizado. Não fui eu, foi meu filho. Eu me sinto mais feliz ainda.

(PLISSON, 2015)

O pai de Nidhi diz como está orgulhoso da filha e se preocupa com a vida da filha fora de casa e com a dificuldade dos estudos, mas é tranquilizado pela própria filha:

Pai de Nidhi - Estou muito orgulhoso de você. Você passou no Super 30.

Nidhi - Que bom!

Pai - Você vai estudar em Patna. Você está feliz?

Nidhi - Muito feliz. Quando eu tenho que ir?

Pai - Logo. Você vai conseguir morar lá sozinha?

Nidhi - Eu vou me virar. Vou morar com outros estudantes.

Pai - As aulas vão ser muito difíceis.

Nidhi - Não se preocupe. Eu só quero a sua bênção.

Pai - Seja feliz. Vá contar a novidade para a sua mãe e para a sua avó.

(PLISSON, 2015)

Nidhi indica que aquilo que espera dos pais não é instrução, mas tão somente seu apoio, sua bênção, que aceitem sua individualidade.

Pai de Nidhi - Eu sou motorista de tuk-tuk. Não tenho dinheiro para mandar a minha filha para uma boa escola. O Super 30 é um presente de Deus para a nossa família. A Nidhi foi selecionada. Deus atendeu o nosso pedido.

Avó de Nidhi - Ela venceu por sua perseverança. Ela estudou sozinha. Ninguém da família tinha condições de ensiná-la. Os pais dela são pouco instruídos. Os avós, menos ainda. Não havia ninguém para ajudá-la. Ter uma criança como ela na família nos deixa muito felizes. Nós temos muito orgulho dela.

(PLISSON, 2015) 
No caso de Nidhi, o filme acompanha ainda a chegada e a recepção na escola e o discurso proferido pelo instrutor na primeira aula. Chegando na escola preparatória Super 30, após felicitar Nidhi pela aprovação, o instrutor pergunta ao pai o que ele faz:

Pai de Nidhi - Sou motorista de tuk-tuk.

Instrutor (ao pai) - O senhor dá duro no trabalho para a sua filha poder estudar.

Instrutor (para Nidhi) - Você também vai ter que dar duro nos estudos. Os seus pais se sacrificam por você. E você deve realizar o sonho deles.

(PLISSON, 2015)

Foi Nidhi que decidiu seguir esse caminho, estudou por conta, sem ter quem auxiliá-la, pesquisou sobre a oportunidade, se inscreveu e passou na prova para se preparar e ter a chance de se tornar engenheira. Ainda assim, que, como forma de retribuir ao sacrifício dos pais, ela deve se esforçar para realizar o sonho deles. Como o sonho pode ser dos pais se todo o caminho, do começo ao fim, foi escolhido e traçado por Nidhi?

A relação deste enunciado com os enunciados anteriormente pronunciados pelo pai, quando pergunta à filha "você está feliz" e quando afirma que "será a primeira a sair de casa" e com a própria fala de Nidhi dizendo que isso pode mudar a situação de toda a família, sugerem que o sonho dos pais não é que ela seja engenheira, mas que ela supere a condição deles, que tenha boas condições de vida, de preferência melhores do que a deles, para que seja feliz, e talvez para que toda a família tenha melhore condições como consequência. $\mathrm{O}$ pai, na cena seguinte, resume: "É claro que estou triste por ficar um ano longe de minha filha. Mas a gente aceita tudo para garantir o futuro dos filhos." Na primeira aula, o instrutor complementa:

Instrutor - Meus jovens, bem-vindos ao Super 30! Estamos orgulhosos e felizes por ter vocês aqui. Vocês foram selecionados entre milhares de jovens carentes. Vocês são simplesmente brilhantes. A educação é a arma mais poderosa para vocês terem sucesso na vida e se libertarem da pobreza. Aqui nós não temos jornais, nem televisão, nem jogos, nem esportes. Vocês estão preparados para aceitar viver assim?

Alunos - Sim, senhor!

Instrutor - Vocês querem escrever o futuro?

Alunos - Sim, senhor!

Instrutor - Fazer a nação evoluir?

Alunos - Sim, senhor!

(PLISSON, 2015) 
Tom é recebido em casa com o apoio da família, que se diz muito orgulhosa, mas nenhum familiar presta depoimento.

Neegii, foi reprovada no teste, mas, como o filme destaca, recebe o apoio da família e é aprovada algum tempo depois. A professora de Neegii é quem entrega a notícia desagradável na primeira vez:

Treinadora de Deegii - Deegii, minha querida, você não foi selecionada. O nível estava muito alto. Poucas meninas conseguiram passar. Foi uma audição muito difícil. Mas sabe por que você não foi selecionada? Você não foi bem. Por causa das suas posições, dos seus joelhos. Você não dobrou os ombros. Mas você progrediu muito, querida. Na próxima audição vai ser diferente. Nós vamos treinar muito mais. Todo dia, só nós duas. Certo? Você não pode desistir, entendeu? Não fique desanimada. Eu preciso ir embora agora.

Pai de Deegii - Você não deve desistir. Da próxima vez você vai passar. Vai ficar tudo bem. Você vai começar a treinar de novo.

(PLISSON, 2015)

Pouco antes do fim, vemos Deegii treinando e uma legenda nos revela que: "Com o apoio de sua família, Deegii voltou a treinar mais motivada do que nunca”. O filme acaba indicando um desdobramento, alguns meses mais tarde, das quatro histórias narradas:

Na Academia, treinando e estudando, Albert continua sonhando em ser campeão olímpico. Roberto continua gesticulando achando que é o melhor treinador cubano. Nidhi foi a 7000a colocada entre 1700 no vestibular da Politécnica e se prepara para ser engenheira. Além de trabalhar como guarda florestal, Tom continua estudando. Ele prepara uma tese sobre grandes primatas. Meses mais tarde, Deegii entrou na renomada Escola de Circo de Singapura. Ela quer realizar seu sonho de artista, seu sonho de infância.

(PLISSON, 2015)

As quatro histórias acabam com a conquista dos sonhos de cada uma das pessoas apresentadas. O efeito de fechamento (BORDWELL, 2005) é construído pelo sucesso no teste, ainda que não no primeiro teste, como foi o caso de Deegii. Com o apoio da família e dedicação pessoal, é possível conquistar seus sonhos? Não. Ainda que diversas vezes o filme tenda para uma defesa de uma simples meritocracia, da perseverança individual como capacidade de reverter um cenário de pobreza familiar, sobretudo quando se apresenta a história e Nidhi, há um outro elemento que não pode ser ignorado. No último depoimento do 
filme, antes de apresentar os desdobramentos, Roberto, grande amigo de Albert, diz, enxugando as lágrimas:

Roberto - Hoje eu perdi um amigo, mas ganhei um campeão. Perdi um amigo, mas ganhei um campeão. Eu espero ser campeão um dia e entrar na Academia, como o Albert. Mas eu não tenho o mesmo talento que o Albert. É isso.

(PLISSON, 2015)

O apoio da família não é a qualquer projeto, mas àqueles que os filhos têm potencial para atingir. É preciso ter o dom de Deegii, enunciado pelo irmão e reforçado pela confiança da professora, ou o talento de Albert, enunciado pelo próprio Roberto e pelo treinador. É essa essência que a família deve apoiar. O fato de se tratar cada criança em sua especificidade, porém, não diminui o tom meritocrático do documentário. Pelo contrário, segmentando-o e articulando-o ao sucesso, ou seja, ao reconhecimento social e não exclusivamente à prosperidade financeira, a exigência do sucesso é apresentada quase como uma condição à liberdade de escolha: se você é bom nisso e quer seguir esse caminho, deve estar entre os melhores.

\subsection{Pequena Miss Sunshine}

Em Pequena Miss Sunshine somos guiados para dentro da casa e da vida dos Hoover. A família é composta pela mãe Sheryl, o pai Richard, o avô paterno Edwin, o tio Frank, o filho adolescente Dwayne e a filha criança Olive, que dividem todos o mesmo teto em New Mexico, nos EUA. O filme acompanha a viagem da família em uma kombi até a Califórnia para levar Olive ao concurso Pequena Miss Sunshine. A questão central é o apoio ou não da família ao projeto altamente questionável de levar a filha a um concurso de miss.

Na primeira cena de Pequena Miss Sunshine vemos a televisão ligada em uma premiação de Miss América que é acompanhada por Olive. O reflexo da tela do televisor nos óculos de Olive permite que a imagem do concurso seja filmada ao mesmo tempo que seus olhos, de modo que vemos Olive olhando para a televisão e o conteúdo transmitido pela tela 
ao mesmo tempo. A câmera se afasta e vemos Olive imitando os gestos da Miss Kansas, Tara Down Holland, que comemora a vitória no concurso.

Depois, conhecemos o pai de Olive, Richard, ministrando uma palestra motivacional:

Pai - Existem dois tipos de pessoas nesse mundo: vencedores e perdedores. Dentro de cada um de vocês, no núcleo de sua existência, há um vencedor esperando ser acordado e libertado no mundo. Com o meu programa de nove passos "Recusa da Derrota" vocês agora tem as ferramentas necessárias, a intuição e o conhecimento para deixarem seus hábitos fracassados pra trás e sair para que seus sonhos tornem-se realidade. Sem hesitação. Sem reclamação. E sem desculpas. Quero que saiam para o mundo e quero que sejam vencedores!

Quando a fala acaba e as luzes se acendem, porém, vemos uma sala quase vazia e um único homem aplaudindo, de modo que o conteúdo do próprio discurso é colocado em questão pela sequência irônica.

O terceiro personagem que conhecemos é Dwayne, o irmão mais velho de Olive. Ele se exercita sozinho, fechado em seu quarto em frente a um grande lençol em que é possível reconhecer, pintado, o característico bigode do filósofo Friedrich Nietzsche. Após a série de exercícios, ele se levanta e risca em seu controle, o dia 977.

Vemos agora o avô de Olive, Edwin, cheirando cocaína em um banheiro com indumentárias femininas e a mãe de Olive, Sheryl, dirigindo enquanto fuma um cigarro e fala ao celular com o marido: "Estou de saída. Não sei quanto tempo levará. Não sei! Richard, ele não tem mais pra onde ir. Não estou fumando. Não estou! Olha, estou no hospital. Sim, ok. Tchau." A câmera mostra Frank Ginsberg, irmão de Sheryl e, portanto, tio de Olive, de camisola em um hospital, com olhar triste, sentado em uma cadeira de rodas. É por cima do rosto de Frank que aparece o título "Pequena Miss Sunshine", indicando que a apresentação das personagens encerrou e que começa agora a trama.

Sheryl entra no hospital para buscar Frank, tio de Olive. Ele acabara de ser socorrido após uma tentativa frustrada de cometer suicídio. Sheryl abraça o irmão, mas ele não reage; se diz feliz que ele ainda esteja vivo, mas ele responde que deve ser a única; pergunta se ele quer conversar, mas ele rejeita a proposta.

Chegando em casa, vemos roupas largadas pelo chão e a mãe anuncia que tio Frank poderá ficar no quarto com Dwayne. São ordens do doutor: ele não deve dormir sozinho e a 
porta deve ficar sempre aberta. A mãe diz que irá preparar o jantar e pede a Dwayne que busque um balde de frangos no carro e que coloque pratos de papelão. Depois, pergunta a Olive se o avô está com ela. Olive responde que estão ensaiando. Chega o pai, carregado de caixas e corre à secretária eletrônica para ver se há mensagens de Stan Grossman, com quem negocia para publicar um livro. $\mathrm{Na}$ ausência de mensagens liga para Grossman, mas é atendido por outra pessoa e pede para que entre em contato.

Quando Dwayne vai chamar o tio Frank para jantar, descobrir que ele não pode falar. O tio faz perguntas e adivinha as resposta pelos gestos do sobrinho. Ele fez um voto de silêncio inspirado por Nietzsche. O tio questiona com quem Dwayne tem passado o tempo e recebe uma resposta por escrito: “eu odeio todos". "E sua família?”, pergunta o tio. Dwayne sublinha a palavra "todos". O tio Frank questiona sua irmã, mãe de Dwayne, sobre o silêncio do filho e ela explica: "Ele irá se alistar na Academia da Força Aérea, será piloto de testes e fez um voto de silêncio até alcançar esse objetivo."

Olive chega feliz, beija o tio e pergunta o que aconteceu com seus braços, demonstrando não saber sobre o ocorrido. O tio diz que foi um acidente. Mudando de assunto, perguntam a Olive quando ela irá apresentar o número, mas ela diz que depende do avô, que a ajuda a ensaiar. $\mathrm{O}$ avô chega à mesa, responde que ela precisa de mais alguns dias e critica a refeição: “O que é isso? Frango? Toda noite é esse maldito frango! Pelo amor de Deus! É possível pelo menos uma vez comermos algo por aqui que não seja esse maldito frango?" Richard censura a atitude do pai e descobrimos que ele foi expulso de Sunset Manor.

Todos os personagens estão agora reunidos pela primeira vez em uma típica cena à mesa. Um padrão nos filmes analisados, a estrutura familiar que foge à família nuclear (pai, mãe e filhos) é novamente justificada. Assim como em Billy Elliot (DALDRY, 2001), foi preciso explicar a morte da mãe e a presença da avó por sua invalidez, em Pequena Miss Sunshine, a presença do tio e do avô são igualmente justificadas pela narrativa: um tentou cometer suicídio e não deve ficar sozinho, o outro foi expulso da casa de repouso por comportamento considerado inadequado pela instituição.

O tio pergunta há quanto tempo Dwayne realiza o voto de silêncio: 
Pai - Passaram-se nove meses, Frank. Não disse uma palavra. Nenhuma. Isso demonstra uma considerável disciplina.

Tio - Acho mesmo.

Pai - É sério. Poderíamos aprender algo com Dwayne. Dwayne tem uma meta. Ele tem um sonho. Pode não ser o meu sonho, pode não ser o seu, mas ele o está perseguindo com grande convicção e concentração. Eu estava pensando nos nove passos.

Mãe - Por todos os céus!

Pai - Dwayne utiliza sete deles em busca da sua realização pessoal.

Mãe - Richard, por favor.

Pai - Bem, só disse que estou convencido. Penso que ele poderia usar nosso apoio.

O pai responde de modo a utilizar a oportunidade para dar uma lição aos filhos e demonstrar apoio. O apoio do pai está direcionado a tornar os filhos “vencedores". Essa ideia é sempre apresentada de modo irônico pela própria construção da trajetória do pai na narrativa, mas os argumentos que são apresentados vão se desconectar, ao longo da narrativa, do resultado e se apresentar de forma menos irônica. Ao reforçar a disciplina necessária para atingir a meta, o pai diz que a meta em si não importa e sim a busca e o resultado: "Ele tem um sonho. Pode não ser o meu sonho, pode não ser o seu, mas ele o está perseguindo com grande convicção e concentração". Ainda diz que deve apoiar o filho, mesmo que o filho não perceba a atitude do pai como um apoio real nesse momento.

Olive pergunta ao tio sobre o "acidente". A mãe tenta desviar o foco, mas o tio diz que “Oh, não, tudo bem. A menos que se oponha.". A mãe então, responde que "Não, aprecio a sinceridade. Só penso que, sabe, depende de você." e conta que o tio tentou se matar. O pai fica indignado: "Creio não ser uma conversa apropriada para uma garota de 7 anos." Olive continua perguntando e o pai tentando censurar a conversa. A mãe argumenta que "Ela irá descobrir mesmo assim". O tio conta que se apaixonou por um aluno, mas que o aluno estava interessado por outro acadêmico: Larry Sugarman, "o segundo mais citado dos Estados Unidos", atrás apenas dele. Frank conta que "disse coisas que não deveria ter dito", que perdeu o trabalho e que, alguns dias antes dessa conversa, a Fundação McArthur concedeu o Troféu Gênio à Larry. Foi, então, que resolveu se matar.

O pai, novamente, dá a última palavra de modo a reinterpretar o ocorrido ao seu modo: "Olive, é importante que entenda que seu tio Frank se deu por vencido. Tomou uma série de decisões tontas. Desculpe E se deu por vencido, algo que vencedores nunca fazem. Então essa é a estória, ok?" 
Nesse ponto do filme, já todas as personagens adultas já foram construídas como anti-heróis ou, para utilizar o termo que o próprio filme reforça pelas falas do pai: "perdedores". O tio, de acordo com a narrativa, teria fracassado no relacionamento amoroso e na vida acadêmica, o avô foi expulso do casa de repouso, o pai não consegue deslanchar no sonho de ser palestrante motivacional e a mãe, que não tem individualidade marcada, que não tem nenhum sonho enunciado por si mesma, é apresentada como dona de casa fracassada, que compra frango frito, serve sprite e pratos de papelão para o jantar. O pai direciona seus esforços aos filhos.

Olive conta que ficou em segundo lugar num concurso de regional de miss e que acha que tem chance de vencer, porque as outras desfilam a mais tempo, mas ela treina diariamente. O tio deseja boa sorte, mas é interrompido pelo pai:

Pai (para Frank)- Não se trata de sorte, Frank. "Sorte" é o nome que perdedores dão à seus próprios fracassos. Se trata de querer ganhar, implorando à si mesmo para ganhar."

Pai (para Olive) - Deve querer isso mais do que ninguém."

Olive - Eu quero.

Pai - Então você será a vencedora. É a verdade.

O pai lembra que há um recada na secretária eletrônica sobre Miss Sunshine. Todos escutam a mensagem. A menina que teria ficado em primeiro lugar foi desclassificada por uso de pílulas de dieta. Olive fica, então, com o primeiro lugar e pode concorrer na competição estadual Pequena Miss Sunshine, em Redondo Beach. Eles não podem pagar passagens de avião. $\mathrm{O}$ avô deve ir junto porque é o treinador. $\mathrm{O}$ tio não pode ficar sozinho. Acham responsabilidade demais deixá-lo sozinho com Dwayne. Todos viajarão juntos de Kombi.

Antes de começar o pai aborda a filha:

Pai - Olive, venha cá um segundo. Sente-se por um segundo. Veja, não tem sentido participar de um concurso se você acha que não irá vencê-lo. Então você acha que pode ganhar o Miss Sol? Irá vencer?

Olive - Sim!

Pai - Estamos indo pra Califórnia.

Na viagem, o avô passa um bom tempo aconselhando Dwayne a fazer bastante sexo enquanto é jovem, com várias garotas. Acrescenta que, quando for maior de idade será crime 
e que ele deve aproveitar agora. O tio pergunta sobre o tempo do avô na casa de repouso e ele conta que fez muito sexo e que foi expulso por usar heroína.

$\mathrm{Na}$ primeira parada cada um tem quatro dólares para gastar com comida. Olive pede waffles "à la mode", com sorvete. O tio explica a expressão francesa, mas é interrompido pelo pai que interroga Olive:

Pai - Frank, cale a boca. Olive, posso te dizer algo sobre o sorvete?

Olive - Sim.

Pai - Bem, sorvete é feito de creme, que vem do leite da vaca. E creme tem muita banha.

Mãe - Richard.

Pai - O quê? Ela irá descobrir, lembra?

Olive - O que? Descobrir o que?

Pai - Bem, quando se toma sorvete, a banha do sorvete torna-se banha corporal.

Mãe - Richard, juro por Deus...

Pai - É a verdade...

Olive - $\mathrm{O}$ quê? O que há de errado?

Pai - Nada, querida. Nada de errado. Então se você toma muito sorvete, pode ser que engorde. E se não tomar, ficará linda e magra, querida.

Olive - Mamãe...

Avô - Olive, Richard é um idiota. Gosto de mulheres com carne em seus ossos.

Olive - Por que estão todos chateados?

Mãe - Ninguém está chateado.

Pai - Só quero que entenda. Tudo bem ser magra, tudo bem ser gorda, se é o que procura. Independente do que optar, tudo bem. Mas, Olive, deixe-me perguntar: As garotas do Miss América são magras ou são gordas? Querida?

Olive - Acho que são magras.

Pai - Sim. Suponho que não tomam muito sorvete.

Garçonete - Ok. Café. Café. Suco de toranja. Camomila. E aqui está seu sorvete."Alamode", certo? Voltarei com seus waffles em um segundo.

Olive - Alguém quer meu sorvete?

O pai apresenta as possibilidades para a filha como igualmente válidas, mas sem questionar a legitimidade da própria proposta de ser Miss América, questiona se esse meio é adequado para aquele fim, de modo a impedir que a filha coma sorvete. Todos os outros, comovidos com o desânimo de Olive, começam a comer o sorvete quando ela oferece. Mesmo o irmão. O avô comenta como está gostoso e como sente "pena de gente que que não quer desfrutar de seu sorvete tão cedo da manhã”. Até que Olive resolve comer.

As falas do pai constroem uma dicotomia fracassado-vencedor que ignora a meta, mas dá atenção total ao processo. É ao processo que ele se dedica, é sobre eles que escreve sua palestra motivacional dos "nove passos". Não há julgamento do fim em si mesmo, mas 
apenas da eficiência dos meios para atingir o resultado, da disciplina, da determinação e da vontade.

Na parada seguinte, Frank consegue falar com Stan Grossman sobre seu contrato para vender os nove passos e é informado que o suposto "acordo concreto" que tinham não irá vingar. Na kombi, o avô consola o próprio filho: "Haja o que houver, você tentou fazer do seu jeito, o que já é mais do que qualquer pessoa faria. E eu me incluo nessa categoria. Você pegou uma grande chance. Isso requeriu coragem, estou orgulhoso."

Quando param para dormir, Sheryl e Richard discutem sobre a situação sem o acordo. Olive e o avô ensaiam grunhidos e conversam sobre o concurso:

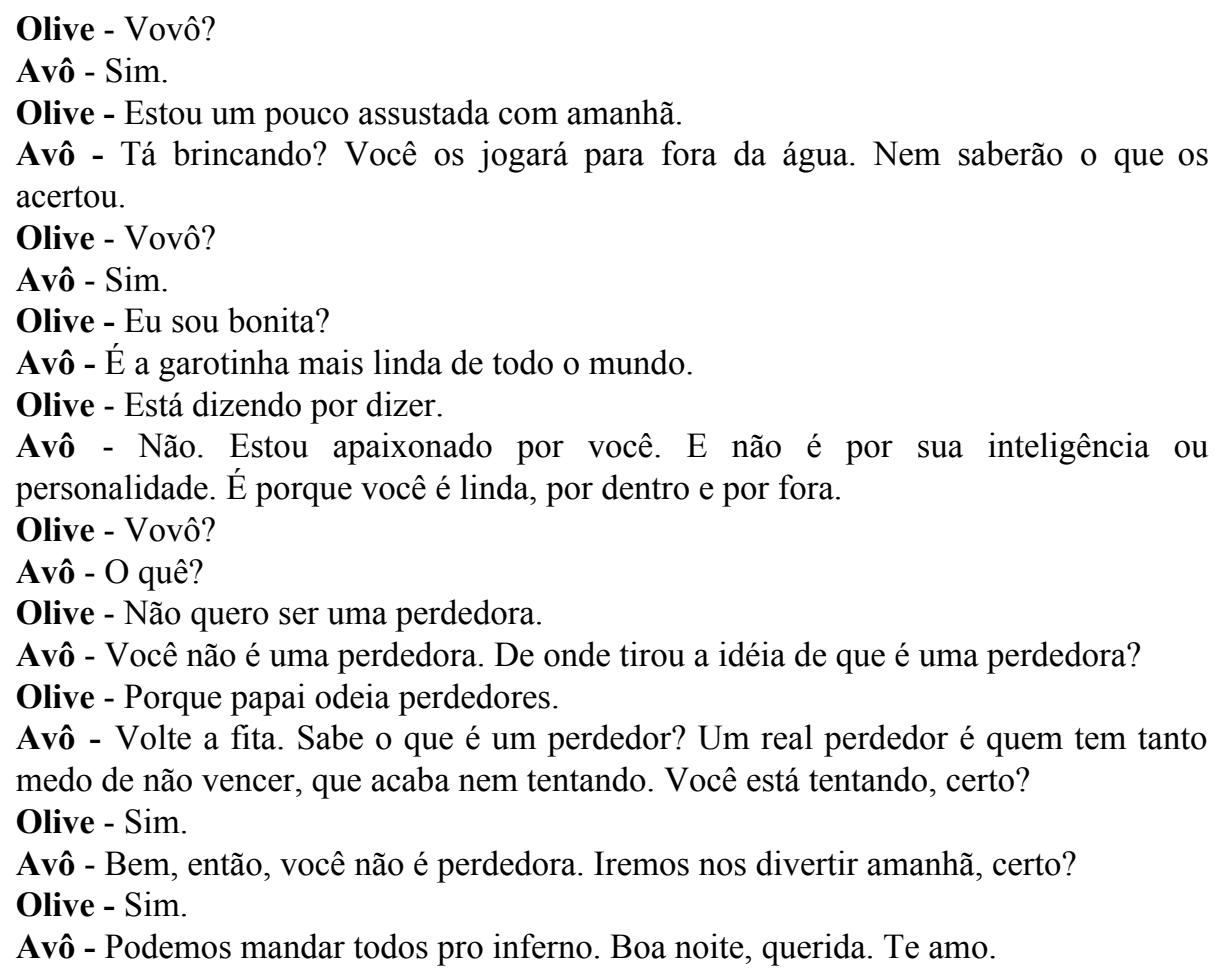

A ideia de "ser vencedor" do pai é reinterpretada pelo avô. Agora, não se trata mais da eficácia dos meios para atingir um fim, trata-se de não ter medo de não vencer, da coragem de tentar e de se divertir.

Na manhã seguinte, Olive vai chamar o avô mas ele não acorda. A família leva Edwin ao hospital, mas ele morre. Como eles já atravessaram a fronteira estadual, uma série questões burocráticas precisam ser resolvidas e impediriam que conseguissem chegar em Albuquerque antes das três horas para o concurso. A mãe diz a Olive que irão ao concurso 
Miss Sunshine no próximo ano, mas o pai, já desiludido com seus próprios planos não aceita: "Não. Não. Viajamos 1100 quilômetros. Ficarei arruinado se faltar a esse concurso, Sheryl." Depois, sugere que levem o corpo do pai:

Pai - Se tem algo que meu pai queria ter visto é a performance de Olive no Miss Sunshine. Agora, acredito que seríamos injustos à memória dele se desistirmos agora. Tudo bem? Há dois tipos de pessoas nesse mundo. Existem vencedores e perdedores, ok? Sabem qual a diferença? Os vencedores não desistem. E o que somos? Somos vencedores ou perdedores?

As cenas seguintes são a parte emocionante do filme. Uma música empolgante acompanha as peripécias da família para colocar o corpo do avô na kombi e para se desvencilhar de um policial que os aborda por conta da buzina quebrada. Quando retomam o caminho, Olive faz testes de visão em Dwayne para passar o tempo e descobre que o irmão é daltônico, o que frustra os planos de se tornar piloto de avião. Eles encostam a kombi e Dwayne tem um momento de raiva:

\footnotetext{
Mãe - Dwayne, querido, sinto muito. Dwayne, vamos. Devemos ir.

Dwayne - Eu não irei. Disse que não vou. Não importa. Não subirei nesse ônibus novamente.

Mãe - Dwayne, para o bem ou para o mal, somos sua família.

Dwayne - Não, não são minha família! Não quero ser parente de vocês! Odeio vocês gente de merda! Odeio vocês! Divórcio, falidos, suicídio! Seus perdedores de merda! São perdedores! Não. Por favor, me deixe aqui, mamãe. Ok? Por favor, por favor, por favor. Por favor, me deixe aqui.
}

Eles não sabem o que fazer. O pai sugere que Olive tenta falar com o irmão. A mãe argumenta que "Não há o que dizer. Só temos é que esperar". Olive vai ao encontro do irmão, passa os braços por seu pescoço, abraçando-o em silêncio, e encosta a cabeça em seu ombro. Dwayne levanta, volta para a kombi e se desculpa pelo que disse. Ao fundo é possível ler uma placa "unidos ficaremos".

Nesse momento, todos da família já fracassaram menos Olive. Diferentemente dos filmes analisados anteriormente, em Pequena Miss Sunshine quase não vemos membros externos à família. Não há nenhuma cena de Olive na escola, por exemplo. A construção da individualidade de Olive não se dá pela comparação em relação outras crianças, não se dá pela identificação de uma norma e de um desvio, mas sim pela repetição das tentativas de 
realização individual de cada membro, construindo essa busca como algo necessário a cada indivíduo.

A aceitação da individualidade também muda: é mais ligada à partilha dos fracassos do que ao desenvolvimento de uma característica extraordinária ou inevitável. Ainda que a busca por realização pessoal de cada membro da família seja bem definida (com exceção da mãe) na construção da narrativa, todos esses projetos são aceitos pela família sem grandes conflitos e a família divide apenas a pena de seu fracasso. Mesmo quando o filho mais velho Dwayne perde a cabeça e insulta o pai, a mãe e o tio (o avô já está morto), ele questiona o fracasso e não aquilo que cada um busca: "Divórcio, falidos, suicídio! Seus perdedores de merda!"

O filme agora se transforma numa empolgante corrida contra o tempo para que Olive possa, com o apoio de todos, chegar ao concurso antes da apresentação. Chegam quatro minutos atrasados. A tensão agora é se conseguirão inscrever Olive. Enquanto os pais tentam resolver esses problemas, tio Frank e Dwayne conversam fora do prédio.

\footnotetext{
Dwayne - Às vezes eu desejo querer dormir até completar 18 anos e ignorar toda essa porcaria, segundo grau e tudo mais.

Tio Frank - Conhece Marcel Proust?

Dwayne - O cara que você ensina.

Tio Frank - Sim. Escritor francês. Um perdedor total. Nunca teve um emprego de verdade. Teve amores não correspondidos. Gay. Passou vinte anos escrevendo um livro que quase ninguém leu. Mas ele deve ser provavelmente o melhor escritor desde Shakespeare. Enfim, ele chegou ao fim de sua vida, olhou pro passado e se deu conta que todos aqueles ano em que sofreu foram os melhores da vida dele, pois mostraram a ele quem ele era. Todos os anos em que era feliz? Sabe, total desperdício. Não aprendeu nada. Então, se dormir até os 18 anos, pense no sofrimento que irá perder. Digo, segundo grau? São os anos de maior sofrimento. Não se consegue sofrimento maior que esse.

Dwayne - Sabe do que mais? Fodam-se os concursos de beleza. A vida é uma porra de um concurso de beleza atrás do outro. Sabe, escola, e então universidade, e então trabalho? Fodam-se. E foda-se a Academia da Força Aérea. Se eu quiser voar, darei um jeito de voar. Você faz o que ama, e foda-se o resto.

Tio Frank - Fico contente que esteja falando novamente, Dwayne. Você não é tão estúpido quanto parecia.
}

O tio, falando da vida Proust, diz a Dwayne que os anos de sofrimento são imprescindíveis porque "mostraram a ele quem ele era". Na fala do tio, o objetivo do desenvolvimento individual é o conhecimento de quem se é verdadeiramente. A conversa entre os dois é também um ponto importante no filme porque generaliza a experiência do 
concurso de beleza, apresentando algo como uma tese subjacente: "a vida é um concurso de beleza atrás do outro". Não se trata apenas da situação de Olive. Essa narrativa, aquilo que ela se propõe ensinar aos pais sobre como se relacionar com os filhos, não é algo específico para Olive, é para todos os pais e todas as crianças. Todos devem viver o sofrimento para saber que realmente são. E os pais devem propiciar isso. A conversa entre os dois já antecipa para o espectador a relativização do resultado do concurso que será construída de forma mais específica a seguir.

As cenas seguintes enaltecem a futilidade, a sexualidazação e as fortes normas de beleza às quais essas meninas estão se sujeitando com a conivência dos pais. Richard observa assustado. Quando já está tudo pronto, o pai chama a mãe de lado, separando-a de Olive e diz: "Não quero que ela continue." Dwayne, já dentro do edifício, observando as outras garotas contra as quais Olive irá concorrer, também se dá conta de quão inadequada é a situação e de como Olive está fora do estereótipo de miss. Ele corre à procura da mãe e da irmã. Quando encontra o pai e a mãe conversando diz:

Dwayne - Mãe, não quero ver Olive fazendo isso. Oh, meu Deus! Olhe em volta. Esse lugar está fodido!

Pai - Ele tem razão!

Dwayne - Olha, não quero que essas pessoas julguem Olive. Fodam-se.

Mãe - Escute, é tarde demais.

Dwayne - Não, não é não.

A mãe sustenta a posição:

Dwayne - Você é a mãe dela e deve protegê-la. Todos irão rir dela, mamãe. Por favor não deixe ela fazer isso.

Voz ao microfone - Olive Hoover, dois minutos.

Dwayne - Olha, ela não é uma rainha da beleza. Simplesmente não é. Irei contar pra ela.

Mãe - Não, Dwayne. Me escute. Olive é quem ela é. Ela trabalhou duro. Se dedicou com tudo a isso. Não podemos tirar isso dela. Não podemos. Sei que quer protegê-la, querido, mas devemos deixar Olive ser Olive.

A mãe realiza, então, um deslocamento que já vinha sendo preparado pelo abraço de Olive no irmão que se descobre daltônico, pelo elogio do avô à tentativa frustrada de seu filho de publicar um livro de autoajuda e pela fala do tio Frank sobre Proust a Dwayne (“Os anos em que foi feliz? Desperdício total. Não aprendeu nada.”). Não se trata, aqui, de apoiar um projeto pensando na sua viabilidade ou no desenvolvimento de um dom, mas de apoiar 
uma vivência, mesmo que sofrida, mesmo que sem perspectivas de conversão em sucesso profissional. O apoio da mãe à Olive desloca nosso olhar da chave sucesso-fracasso, deixando de lado o questionamento sobre a viabilidade ou mesmo pela legitimidade do projeto e nos leva a pensar em um apoio ligado à construção da personalidade. Assim como o tio defende que o sofrimento permitiu que Proust descobrisse quem era, Olive precisa passar por isso para se encontrar. O importante não é mais não ser um fracassado, tal qual pregava o pai nas palestras e nos sermões aos filhos, mas viver essa experiência de maneira intensa, plena, e de se aceitar o outro independentemente do sucesso. Os pais devem proporcionar experiências que permitam aos filhos descobrir quem são: "Não podemos tirar isso dela. Sei que quer protegê-la, mas temos de deixar Olive ser Olive. "

\section{Figura 6 - Cena do filme Pequena Miss Sunshine em que a mãe defende que a filha participe do} concurso de beleza: "Devemos deixar Olive ser Olive".

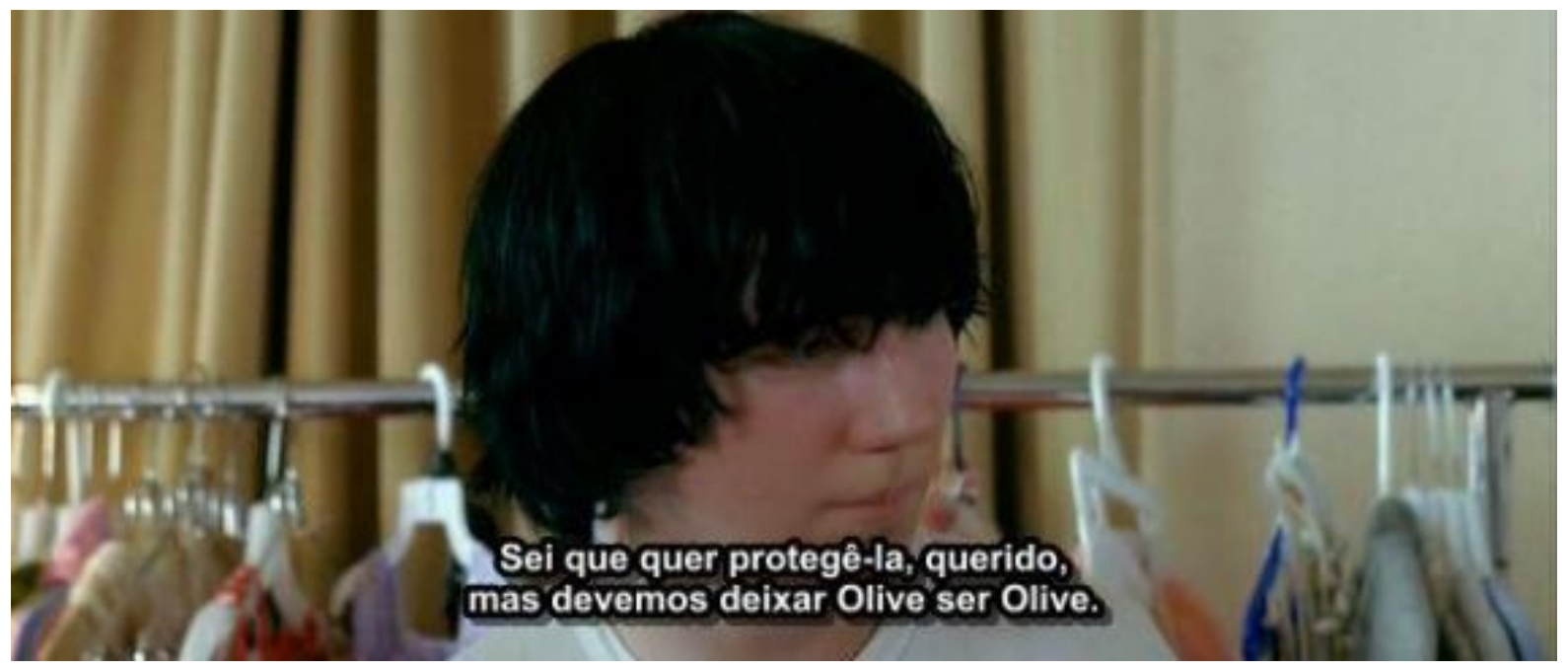

Fonte: print screen do filme Moana.

O sentimento de família em Pequena Miss Sunshine está ligado a uma aceitação que passa pela abdicação do controle total das influências na vida dos filhos, pela abdicação do controle dos desejos e da tentativa de realizá-los, em prol de uma condução para que a vivência da tentativa de realização do projeto (independente do resultado) seja forte. E esse sentimento, em Pequena Miss Sunshine, é construído a partir da multiplicação dos projetos individuais e da saturação das experiências de frustração. 
No livro A Sociologia da Família Contemporânea, o sociólogo François de Singly (2007) introduz as especificidades da família de nosso tempo tomando como exemplo o filme Pequena Miss Sunshine. O autor enfatiza, na apresentação do filme, que há na família Hoover uma conciliação entre pertença e singularidade característica da família contemporânea. De acordo com Singly, no filme, "só através da mobilização coletiva em torno do projeto de Olive [esse grupo] se torna família”. Assim, destaca que a família contemporânea, ilustrada pelos Hoover, não tem lugares definidos, nem é marcada pela disciplina. É uma família personalizada, marca da contemporaneidade. Cada grupo inventa sua própria família construindo um sentimento de pertença e um ambiente que favoreça o desenvolvimento da "própria identidade" de cada membro do grupo, de forma a "desenvolver-se ao mesmo tempo em que participa de uma obra comum". (SINGLY, 2007).

Ao contrário dos outros filmes, porém, essa validação é totalmente interna à família. Não há nenhuma figura de especialista que indique à família uma característica inelutável ou um dom não reconhecido. A aceitação da característica perde espaço para a criação de um um ambiente favorável ao processo de construção ou de descoberta da própria personalidade.

Rosa Maria Bueno Fischer, escreve sobre Pequena Miss Sunshine, que "nós, espectadores, não reagimos ao desejo da menina - apenas acompanhamos, atentos, o desenrolar de uma trajetória destinada ao fracasso" (FISCHER, 2008). No filme, esses projetos são todos fadados ao fracasso, de modo que o foco passa a ser não o projeto, mas o próprio processo de aceitação familiar incondicional à individualidade de cada membro como constitutivo desse sentimento de família. O enunciado de que os pais devem aceitar os filhos como são continua presente e é central para a construção da narrativa e é parte importante da construção do efeito de fechamento (BORDWELL, 2005) do filme. Olive participa do concurso, realiza uma dança totalmente inadequada e sexualizada para sua idade, remetendo a danças de streap tease. Toda família se une à Olive e dança no palco unida. $\mathrm{O}$ fillme reforça, assim, a aceitação da família.

Fischer (2008) desenvolve uma análise do filme apresentado no título a partir das contribuições de Foucault, Alain Badiou, Ismail Xavier e Jurandir Freire Costa. A autora observa que há uma dimensão da análise desse filme que seria óbvia, que seria opor as dificuldades da família Hoover aos sonhos da cultura norte-americana, mas destaca que, para ir além dessa dimensão 
Não se trata de interpretar cada gesto dos personagens, cada fala, e encontrar neles, finalmente, uma explicação causal, a representação de algo que seria exterior à narrativa e às personagens do filme analisado, fatos comprovadores de uma tese que estariam ali expostos, como reprodução de uma dada realidade. (FISCHER, 2008)

Em outras palavras, não se trata de tomar o filme como representação, e sim, como sugere Ismail Xavier, em seu efeito-de-superfície, ou, como sugere Michel Foucault, como discurso. A autora caracteriza o filme como uma "saga de seus anti-heróis americanos que, talvez por essa condição de serem 'menos' na sociedade em que vivem, dão-se a ver como heróis, na medida em que põem a nu um por um os valores já cristalizados dessa mesma sociedade." (FISCHER, 2008) Porém, destaca que "a complexidade de cada um dos personagens como Sherryl, produz algo diferente em nós”, um “espasmo de significado”. Por fim, a partir das análises de Foucault sobre a antiguidade, a autora argumenta que

\footnotetext{
o cinema, partindo dos imaginários dominantes, das relações dadas historicamente, das "impurezas" próprias de qualquer produção cinematográfica - ao criar imagens que ultrapassam os níveis informativos e simbólicos da comunicação, ao buscar atingir espaços de uma certa pureza e ao abrir espaço aos "sentidos obtusos" -, esteja também oferecendo material para o aperfeiçoamento de cada um de nós, no sentido grego do cuidado consigo mesmo. (FISCHER, 2008)
}

Assim, a autora defende uma possibilidade de transformação por meio de filmes que, partindo do imaginário dominante, busque essa "pureza provisória" e nos permita realizar um exercício de aperfeiçoamento do cuidado de si. Mais do que às conclusões às quais a autora chega, confrontando o filme com questões que não são as nossas, atentamos para o fato que as personagens, mesmo que construídas como anti-heróis, não são estereotipadas. São complexas. São dotadas de individualidade. Ao contrário dos filmes analisados anteriormente, em Pequena Miss Sunshine, é exatamente pelo exemplo da construção da individualidade de cada membro buscando seus projetos, que Olive é ensinada a buscar a sua própria. Não se trata apenas, aqui, de aceitar os filhos como eles são. É preciso buscar a próprio individualidade de forma saudável, de modo que os filhos possam aprender, pelo exemplo, a buscar as próprias individualidades.

Mesmo com a alteração da norma, a individualidade da mãe não é construída na narrativa. Sheryl é construída como fracassada no papel de esposa e de dona de casa, mas não tem individualidade dentro da família. É ela, ainda, quem apoia Olive nesse processo, mesmo quando todos querem impedi-la. A dimensão do sacrifício e da devoção total aos filhos, 
portanto, não desaparece. Mas a ela se soma a exigência da busca pela própria personalidade. Aceitar os filhos como eles são, se dedicar totalmente a eles, mas sem abdicar da busca pela própria individualidade.

\subsection{Incompreendida}

O filme começa com a menina Aria, de nove anos, escrevendo e desenhando em seu diário em meio a recortes de revistas com ícones da cultura pop: "Ist \& Ist", "Aria is the Best", "Aria is strong". A voz de Aria entra lendo o próprio diário: "A gata da Angelica teve cinco gatinhos. Quem sabe os meus pais não ficam com um? Já pensei no nome: Dac.” A ideia do gato e o gatinho vão acompanhá-la ao longo do filme, sua única companhia.

A cena seguinte é um jantar com todos da família à mesa. $\mathrm{O}$ homem joga o sal por cima dos ombros enquanto a mulher serve a comida sem sorrir. Além deles, três meninas à mesa. Logo é revelado, por meio das críticas aos companheiros anteriores, que cada menina é fruto de um relacionamento diferente: uma do pai com outra mulher, uma da mãe com outro homem e Aria, dos dois. A mãe toca piano com a filha de seu casamento anterior, Donatina. O pai lê com a filha de seu casamento anterior. Aria sobra. O caderno de piano está rabiscado. Aria percebe que são os mesmos sinais do caderno da outra irmã, Lucrezia. Tenta dedurá-la, mas é reprimida pelo pai: "Quem espia não é filho de Maria, não é filho de Jesus. Morre e fica com o homenzinho que se chama diabinho. Quer ir para o inferno também?". Logo em seguida, Aria joga a almôndega pela janela e é dedurada por Lucrezia.

O pai, Guido Bernadotte, é um ator de cinema famoso e supersticioso. A mãe, Yvonne Casella, é pianista e comunista. Lucrezia, filha de Guido, é retratada como fútil e sempre cria situações para provocar Aria, excluí-la e ter a atenção exclusiva do pai. Donatina, filha de Yvonne, aprende piano com a mãe e é maquiada por ela. Aria, filha de Guido e Yvonne, fica no meio do caminho. 
Fica logo evidente que Aria é preterida em relação às irmãs, não recebendo a mesma atenção. A mãe bate na filha. O pai bate na mãe. A mãe chama o pai de monstro. Aria leva a mão ao próprio machucado.

Figura 7 - Cena do filme Incompreendida em que a mãe chama o pai de monstro e Aria leva a mão ao machucado causado pelo tapa que a mãe the deu.

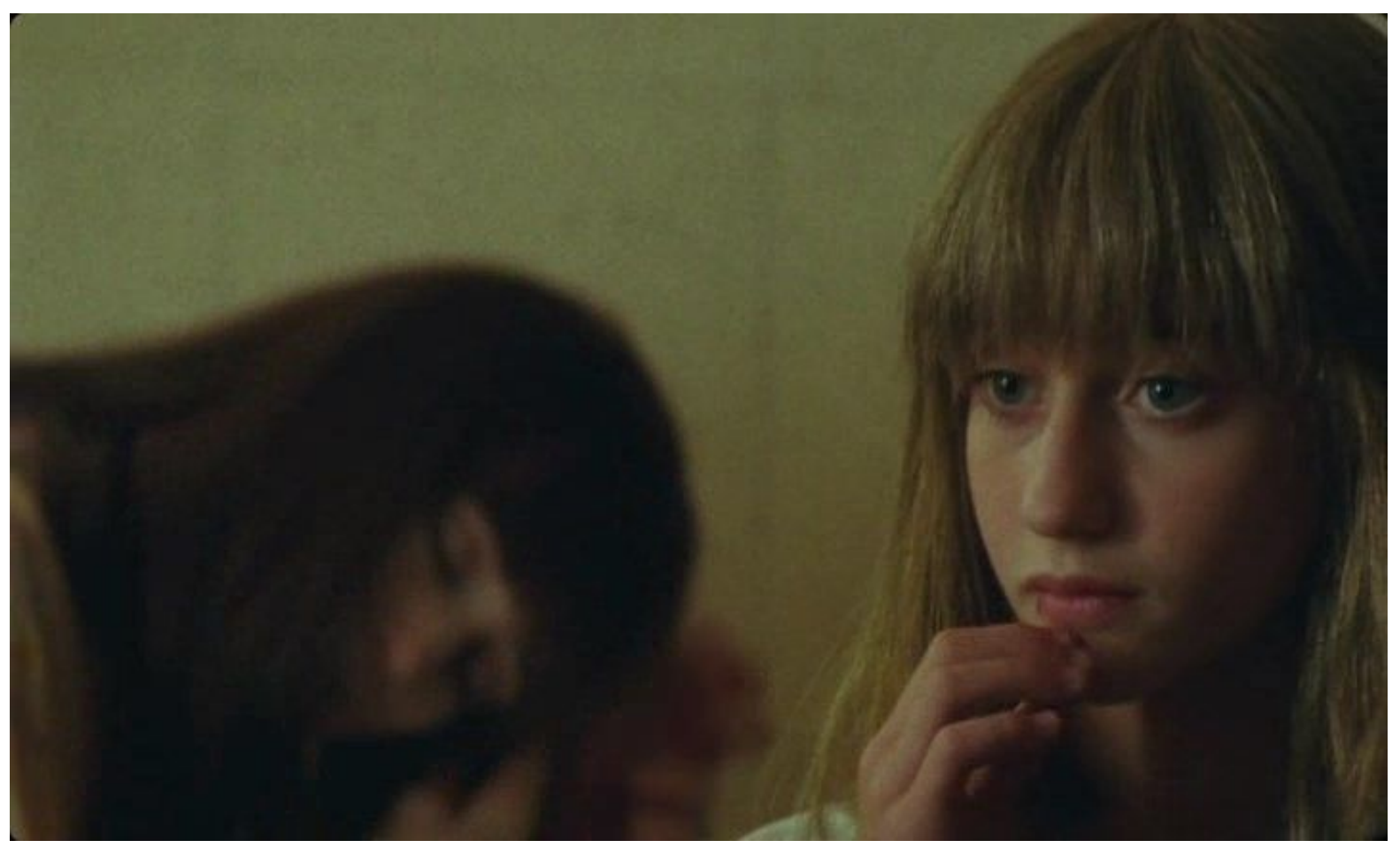

Fonte: print screen do filme Incompreendida.

A dinâmica se repete ao longo de todo o filme. O pai acusa a mãe enquanto age de forma similar; a mãe acusa o pai enquanto age de forma similar.

Aria - Vai me expulsar por causa do gato?

Guido (pai) - Não! Porque a sua mãe é uma puta! Uma louca de manicômio! Larga a filha... para viajar com o primeiro imbecil que aparece. Que mãe é essa? Mulheres assim nem deveriam fazer filhos. Deveria ser proibido por lei! Por lei! Ela cria muito bem vocês. Vão virar duas drogadas. Duas marginais, imbecis feito ela! Perdi dez anos com aquela cretina! Imagine só.

Enquanto diz essas palavras, o pai expulsa a filha que vai com seu gato e sua sacola a pé para a casa da mãe.

Aria - Mãe, sou eu. O papai me mandou embora. 
Yvonne (mãe) - O quê? Ele não pode fazer isso. É maluco? Não se manda filho embora. Não posso ficar com você. Vou viajar de novo. Vá embora!

Enquanto diz essas palavras, a mãe expulsa a filha que vai com seu gato e sua sacola a pé para a casa do pai. A cena se repete a cada desentendimento, cada vez que Aria é vista como um problema, como um impedimento aos projetos individuais do pai ou da mãe, cada vez que um deles se cansa, manda Aria para a casa do outro.

O filme começa com a separação dos pais e acaba com a segunda tentativa de suicídio de Aria.

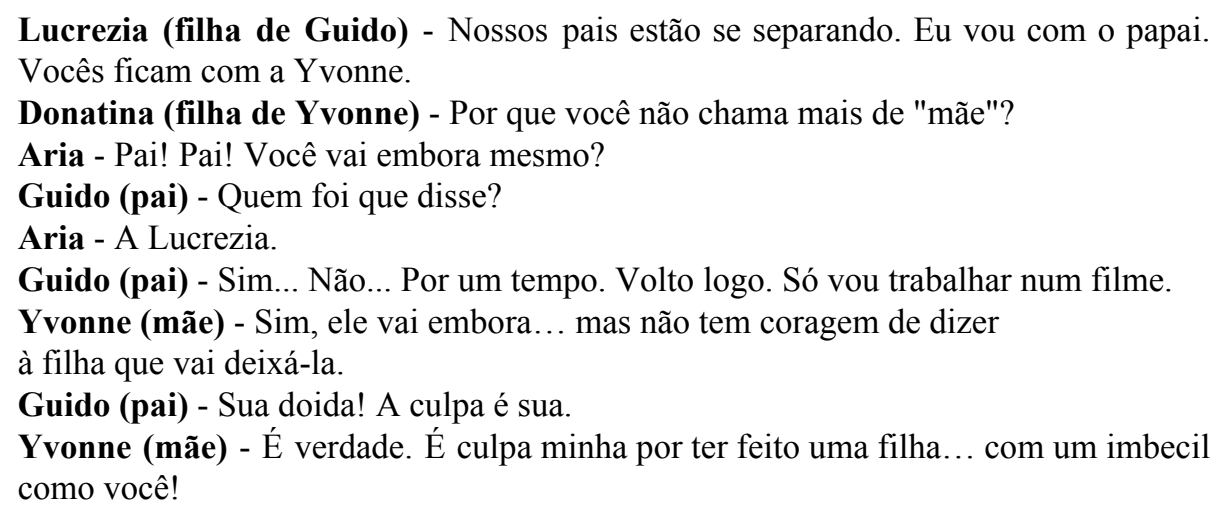

Uma vez separados, a mãe diz à filha que será tudo melhor, que irão viajar em um cruzeiro e faz promessas, que logo em seguida se provam falsas, dinâmica que também se repete algumas vezes ao longo do filme. A repetição e a simetria entre o comportamento dos pais criam um padrão, que permite prever o comportamento que pode ser esperado dos pais, ainda que ocasionalmente rompam o padrão e se mostrem bastante carinhosos, quando lhes convêm.

Entre a casa de um e a casa do outro, Aria encontra um gato preto, que adota e chama de Dac, como havia planejado em seu diário. Uma noite, negada tanto pelo pai quanto pela mãe, fica sozinha, na rua, no meio do caminho, apenas com o gato:

A mamãe tem a Donatina... o papai tem a Lucrezia. Eu tenho você. Dac. Não quero parecer uma menina abandonada. Em parte sim, por isso sou tão livre. Estou me divertindo muito. Nenhuma criança pode andar por aí a esta hora. Nós dois somos "Os Selvagens da Noite". 
Ela e o gato, param, então, não parecerem abandonados, mas livres, se juntam a um grupo de pessoas que bebiam, fumavam e dançavam na praça e passam a noite com eles, bebendo, fumando e dançando. É sobre o gato que Aria escreve uma redação na escola, que ganha o prêmio de melhor redação de Roma. Quando a mãe chega acelerada de uma festa e acorda as filhas para conhecerem a "dança do quadrado", Aria chama-a para a cerimônia e pede que prometa que estará lá. A mãe promete enquanto dança, sem prestar atenção.

Durante a cerimônia, Aria lê a redação premiada:

O Meu Anjo da Guarda. Não acho que o anjo da guarda... seja um guardião invisível... que nos espia. Isso me assustaria como um fantasma... porque ele me vê, mas eu não o vejo. Acho que o anjo entra em alguém que está perto de nós... e nos protege. $\mathrm{O}$ meu entrou num gato preto que se chama Dac. Quando ninguém percebe que quero um carinho... ele percebe. Todos os carinhos que não recebo eu dou a ele. Um pequeno gesto de amor eu faço durar como um pirulito. Vocês sabem o que é um pirulito? É uma bala redonda... que parece não acabar nunca. Mas acaba. É uma bala imaginária, como o amor.

O amor é uma bala imaginária, que acaba. Enquanto lê a redação, Aria imagina os pais entrando e toda a imagem muda de cor, mas tão logo acaba a leitura, volta-se a situação anterior e as cadeiras reservadas aos pais continuam vazias.

Aria tem uma melhor amiga: Angélica. São inseparáveis. Depois descobrimos que se chamam de Ist e Ist, como Aria havia escrito no caderno. Os meninos apontam para elas na aula de educação física, falam que Aria não tem peitos, que é uma nota dois, implicam com elas. Elas se perguntam por quê: "Por que perseguem a gente? Nem peito a gente tem." A amiga responde: "Não interessa. Somos diferentes.Ninguém tem coragem de se vestir como nós. Somos as mais descoladas." Diferentes dos outros, iguais entre si. Sempre que se encontram, Aria e Angélica fazem sinais, e dizem "Somos iguais, Ist".

Mas a amizade com Angélica também não dura o filme inteiro. O pai a abandona, a mãe a abandona e Angélica, também a abandona quando são pegas roubando cartas e o porteiro ameaça chamar os pais das crianças. Ameaça que não tem efeitos para Aria, mas tem muitos efeitos para Angélica que implora: Não os meus não". Depois, diz que chamou a polícia, ao que Angélica reage:

Angélica (amiga) - Satisfeita? A polícia, entendeu? E vai sobrar pra mim. Vou dizer que é tudo culpa sua. Me fez violentar as bonecas, fumar, jogar bexigas com água.

Aria - Mas você gostava. 
Angélica (amiga) - Não! Não sou igual a você. Sou uma menina normal.

A construção da incompreensão, em Incompreendida, está articulada ao amor ou à ausência dele. Após chamar Adriano, o menino por quem está interessada, e não saber o que dizer, Aria reflete: “Eu só queria um pouco de compreensão. Um amor sólido e doce. Só queria um pouco de humildade."

A situação da menina se agrava já próxima ao final do filme, com dois eventos. Primeiro, quando a mãe recebe um pacote de drogas pelo correio e é abordada pela polícia. Ela finge não conhecer o remetente, mas a Aria, ingenuamente, lhe entrega: "Como assim, mãe? Manuel Ginori. Aquele de bigode, simpático. O que deu bonecas pra gente. O Manuel.” A mãe é presa e o pai é procurado pela polícia. O pai interfona para a filha e lhe diz pelo aparelho:

\footnotetext{
Não quero saber de você! Por sua causa, levaram o meu filme. Preso por tráfico. Estou arruinado. Arruinado! Prendem a sua mãe, e você não me avisa? Você é tonta? Eu e a Lucrezia vamos para a Índia... e você não vai me ver mais. Nunca mais! Você não é minha filha, é informante da polícia.
}

"Ninguém me ama", ela chega a afirmar. Abandonada, a menina resolve dar uma festa na casa do pai, que está vazia e acontece o segundo evento. O menino Adriano, de quem Aria gosta, arma-lhe uma situação em um jogo em que os escolhidos deveriam se beijar. No quarto escuro, no lugar de Adriano, vai outro menino, que gosta de Aria, e ela beija-o enganada. A cena é o retrato da humilhação, com todos rindo de Aria e depredando a casa de seu pai.

Sozinha em casa, assiste televisão enquanto escuta a avó falando ao telefone: "Não mandem a menina para o internato. Verdade como? E o pai diz o quê? É filha de vocês. Como podem ser tão cruéis? Ela só tem nove anos. Ela fez com vocês? E o que vocês fizeram com ela?". Na tela, vemos “Quando o Amor é Cruel”, de Luigi Comencini, o filme tratado no capítulo anterior, justamente na cena em que Andrea, na cama, diz: "Não quero viver sem a minha mãe. Mas sempre vou estar por perto, sempre ao seu lado. Não, você não gosta de mim.” A menina caminha até a sacada e se joga de cabeça.

A trama termina com Aria sendo levada de maca em um hospital, pai e mãe abraçados observando. A música e a aparição por escrito do título Incompreendida indicam que a 
narrativa se encerrou, mas Aria aparece novamente, repetindo uma última vez a cena em que caminha com o gato e a sacola pela rua, abandonada pelo pai e pela mãe. Ela deixa seus pertences no chão, se vira para a câmera e, olhando-nos nos olhos, diz: "Contei tudo isso não pra me fazer de vítima, mas para que me conheçam melhor. E, talvez, sejam um pouco mais gentis."

Figura 8 - Cena final do filme Incompreendida.

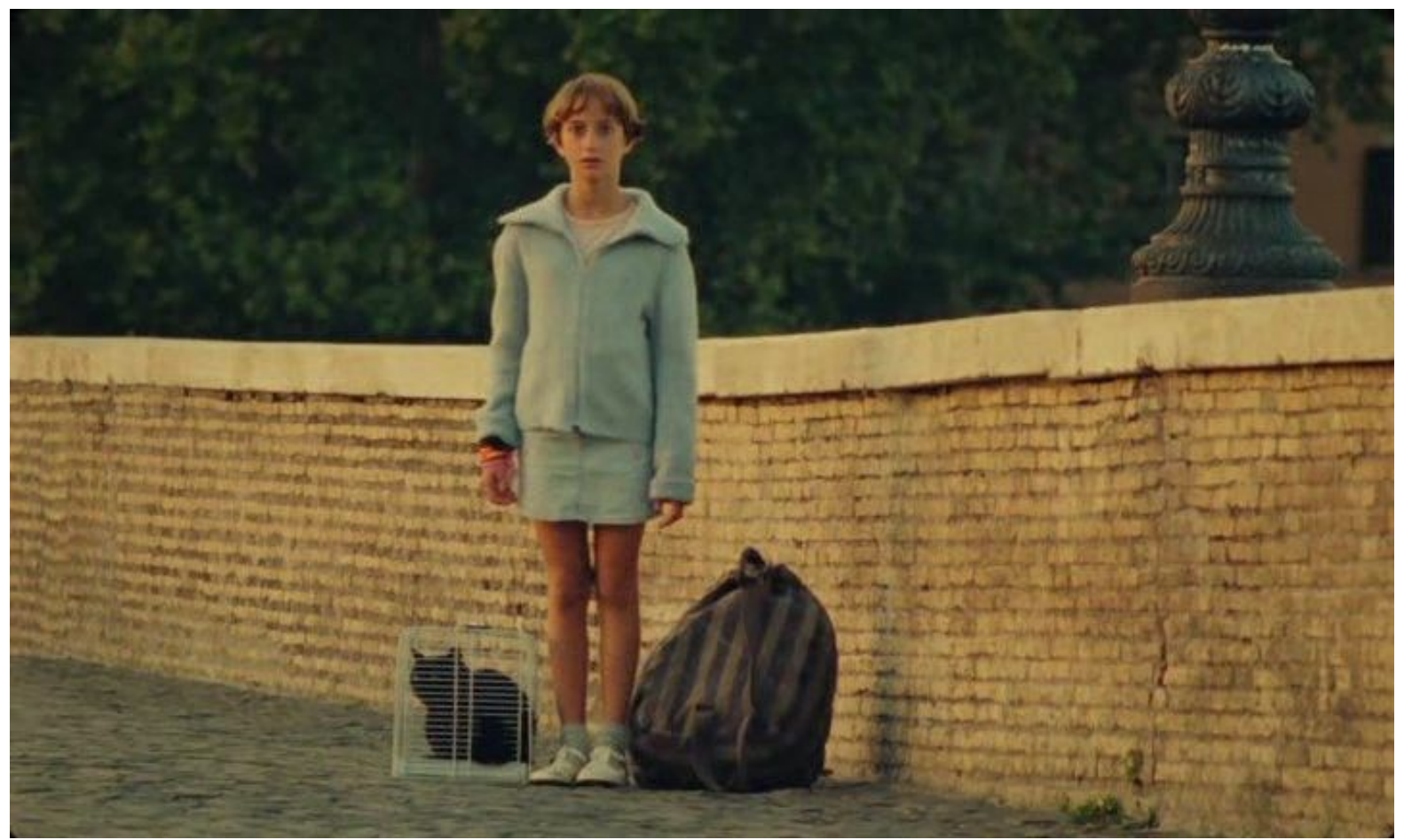

Fonte: print screen do filme Incompreendida.

Assim, o filme acaba do mesmo jeito que começa o livro de 1869, deixando claras suas pretensões educativas: trata-se de um filme que pretende civilizar os pais, ensiná-los como viver em família.

Ser compreendida, aqui, se articula com o enunciado "ter um amor sólido". A criança é incompreendida porque não é amada, porque o amor que têm por ela acaba, como um pirulito. Porque, quando convém à mãe ou ao pai, eles estão juntos dela, quando não convém, a empurram para fora. Se por um lado, neste filme ter individualidade, sonhos próprios, projetos e ambições não é mais uma exclusividade do pai, por outro lado, os filhos são vistos apenas como barreiras a realização de seus objetivos e prazeres individuais. Não há a 
dimensão do sacrifício, tão forte em Billy Elliot. Ou melhor, a dimensão do sacrifício está presente no filme inteiro, como uma ausência. Incompreendida, assim como Misunderstood (1869) e Quando o Amor é Cruel (1966), cada um a seu modo, educam pela tragédia, pela morte, mostrando como não devem agir os pais. Desta forma, a ausência da dimensão do sacrifício, a ausência dos pais, o não envolvimento com os interesses da filha, tudo isso se torna a visão, em negativo, de uma norma.

Incompreendida, apresenta uma família que se aproxima do ideal pós-moderno em que cada membro tem uma individualidade própria e constrói sua identidade em torno da realização de um projeto individual, mas o faz de forma negativa, como um modelo a ser evitado, exaltando os problemas oriundos desse modo de viver em família. Desta forma, acaba por reforçar o ideal de família moderna presente nos outros filmes e reforçando um mesmo discurso de aceitação do filho como ele é, de atenção para a identificação de características próprias do filho que devem ser estimuladas e valorizadas e do sacrifício pelos filhos mesmo quando os pais não compreendem a forma como se desenvolve sua individualidade.

O lamento de Aria, desejante de um amor sólido, humilde, nos remete aos textos de Zygmunt Bauman sobre o amor líquido. A partir da leitura de Erich Fromm, Bauman escreve que o amor é uma relação com o desconhecido, uma relação construída que exigiria grande dose de humildade e coragem, características que teriam se perdido em uma sociedade de consumo, que busca no amor uma mercadoria pronta como qualquer outra.

\footnotetext{
E assim é numa cultura consumista como a nossa, que favorece o produto pronto para uso imediato, o prazer passageiro, a satisfação instantânea, resultados que não exijam esforços prolongados, receitas testadas, garantias de seguro total e devolução do dinheiro. A promessa de aprender a arte de amar é a oferta (falsa, enganosa, mas que se deseja ardentemente que seja verdadeira) de construir a "experiência amorosa" à semelhança de outras mercadorias, que fascinam e seduzem exibindo todas essas características e prometem desejo sem ansiedade, esforço sem suor e resultados sem esforço. Sem humildade e coragem não há amor. Essas duas qualidades são exigidas, em escalas enormes e contínuas, quando se ingressa numa terra inexplorada e não-mapeada. E é a esse território que o amor conduz ao se instalar entre dois ou mais seres humanos. (BAUMAN, 2004, p.21)
}

Bauman não está se referindo, nessas passagens, ao amor entre pais e filhos, mas o lamento de Aria se referindo a um conceito tão famoso do filósofo polonês, intencionalmente 
ou não, permite essa aproximação. Ao observar o amor dos pais de Aria como uma amor líquido, podemos estabelecer um contraste entre esse filme e Billy Elliot, que, de acordo com o professor Julio Groppa Aquino (2011), poderia bem ilustra uma dimensão de sacrifício, praticamente inexistente nas camadas médias urbanas hoje.

Em entrevista a uma revista brasileira, pouco tempo antes de falecer, Zygmunt Bauman respondeu, de forma resumida, o que entendia por "amor líquido":

\begin{abstract}
Amor líquido é um amor "até segundo aviso", o amor a partir do padrão dos bens de consumo: mantenha-os enquanto eles te trouxerem satisfação e os substitua por outros que prometem ainda mais satisfação. $\mathrm{O}$ amor com um espectro de eliminação imediata e, assim, também de ansiedade permanente, pairando acima dele. Na sua forma "líquida", o amor tenta substituir a qualidade por quantidade - mas isso nunca pode ser feito, como seus praticantes mais cedo ou mais tarde acabam percebendo. É bom lembrar que o amor não é um "objeto encontrado", mas um produto de um longo e muitas vezes difícil esforço e de boa vontade.
\end{abstract}

(BAUMAN, 2010)

A caracterização do amor líquido como amor até segundo aviso permite enxergar no filme uma coerência entre os gestos aparentemente incoerentes dos pais, que ora cuidam, ninam, acariciam, ora abandonam, batem e a expulsam de casa, de acordo com sua conveniência, sem sacrifícios. Uma vez que o efeito de fechamento de Incompreendida é moralizante, que o filme se constrói como uma grande mensagem daquilo a ser evitado, pode-se afirmar que tanto Billy Elliot quanto Incompreendida ressaltam a necessidade de um amor sólido como norma das relações entre pais e filhos.

$\mathrm{O}$ amor líquido de Incompreendida apaga inclusive os próprios limites entre adultos e crianças. Enquanto no texto de 1869 o menino Humphrey crê na infalibilidade dos adultos, pois acredita que eles detêm os segredos da vida. (MONTGOMERY, 1869, p.209), no filme Incompreendida de 2014 os adultos se tornam crianças-adultas e as crianças se tornam adultos-crianças. Não mais como uma analogia para falar de nossa dependência em relação à Deus, mas como uma indistinção, nos moldes da análise proposta por Neil Postman em $O$ Desaparecimento da Infância (1999).

Também, e talvez menos evidenciado pela literatura sobre o tema, quando identificamos, em um conjunto de filmes contemporâneos sobre relações entre pais e filhos crianças, um discurso comum que ensina os pais a "aceitarem o filho como ele é”, é possível 
estabelecer um contraste aparente entre uma família que segue esse radicalmente esse discurso em Pequena Miss Sunshine e uma família que não segue em momento algum, em Incompreendida.

O sociólogo francês François de Singly, em uma determinada passagem de seu livro Sociologia da Família Contemporânea, afirma que a construção de normas na contemporaneidade, que ele classifica como "segunda modernidade", se daria justamente por meio desse jogo de contrastes.

\begin{abstract}
Estes constrangimentos não tomam a forma de normas. Na segunda modernidade, elas são originais. Primeiro, não são consideradas como normas por aqueles que as enunciam. Segundo e com mais frequência, não tomam a forma de uma "ordem", exigindo uma obediência obrigatória. Propõem um equilíbrio difícil de alcançar entre dois pólos apresentados como excessos. Terceiro, exigem especialistas que garantam a educação posta em prática e uma formação contínua dos pais: "ensinar os pais a serem pais" tornou-se, desde os anos 1990, uma das palavras de ordem que as políticas familiares têm em comum.(SINGLY, 2011, p. 62)
\end{abstract}

Ao apresentar dois pólos opostos, ambos como excessivos, as famílias se encontrariam na difícil situação de encontrar um equilíbrio, de tal forma que a norma não é percebida como norma. Que seja possível identificar, em uma extremidade um filme como Pequena Miss Sunshine e na outra Incompreendida, que, aparentemente, tensionam o discurso dos outros filmes, isso apenas reforça a própria norma construída nesses filmes sobre como os pais devem educar os filhos.

Singly ainda escreve que esse processo de transformações da família na contemporaneidade ocorreria como um prolongamento do processo civilizador descrito por Norbert Elias, “caracterizado pela interiorização cada vez mais forte das normas sociais". É pela construção dessas normas que se ensina o indivíduo a ser indivíduo, mas também os pais a serem pais. Poderíamos falar, citando um texto menos famoso de Elias, em um processo de civilização dos pais.

Identificamos esse processo de civilização dos pais já no século XIX, com Incompreendido, de Florence Montgomery, quando a criança passa a ser elaborada discursivamente como incompreendida. Apresentemos, pelo jogo de contrastes entre o livro de 1869, sua transformação em filme em 1966 e sua livre adaptação em 2014 e outros filmes tomados em conjunto com estes, uma continuidade desse processo e algumas rupturas no 
discurso sobre a compreensão dos filhos. Destacamos que é possível identificar hoje, nos filmes sobre relacionamentos familiares com crianças, um discurso comum centrado no enunciado de "aceitar seu filho como ele é" e como, mesmo dois filmes que parecem tensionar esse discurso, reforçam essa norma pelos excessos, sem que ela seja percebida enquanto norma. 


\subsection{Aceitar os filhos como eles são}

A seleção dos filmes contemporâneos, todos lançados comercialmente no Brasil, portanto, produções de amplo alcance, foi realizada por um filtro temático: todos são filmes centrados nas relações entre pais adultos e filhos crianças. Por outro lado, a seleção seguiu também um critério de uma diversidade aparente: um menino que quer fazer balé, um menino que ser menina, uma menina que fala em uma família surda, uma menina que sai de casa para cumprir uma profecia e salvar seu povo, crianças ao redor do mundo que se preparam para um dia decisivo, uma menina que quer participar de um concurso de beleza e, finalmente, uma menina incompreendida pelos pais divorciados. Também incluímos uma animação e um documentário para poder observar possíveis nuances entre essas formas de produção e as séries enunciativas ali veiculadas.

No entanto, a partir de uma análise de superfície, ou seja, de uma análise dos enunciados nos jogos de sua articulação no próprio filme, sem remeter a uma verdade oculta que eles poderiam “querer dizer”, inspirada nas propostas de Michel Foucault, constatamos que há um enunciado que é recorrente em todos e que é central para o desenvolvimento da trama e para o efeito de fechamento (BORDWELL, 2005) de todos esses filmes, que é: os pais devem aceitar os filhos como eles são.

Sarah Harwood (1997), a partir das análises de Virginia Wexman, argumenta que o efeito de fechamento dos filmes hollywoodianos se dá, em grande parte dos filmes hollywoodianos centrados em romances heterossexuais, pela construção de uma família incipiente como uma unidade geradora potencial. Harwood chama esse modo de fechamento de Final Romance para depois argumentar que nos anos 1980 esse modo de fechamento já não é mais garantia, sendo as alianças apresentadas nos filmes codificadas como altamente instáveis. De acordo com Harwood, o conflito narrativo da mulher-como-problema das femme-fatales do film noir é deslocado, nos anos 1980, para o pai-como-problema.

A partir da análise das produções fílmicas comerciais contemporâneas (1997 a 2016) centradas na relação entre pais e filhos selecionadas, é possível afirmar que há regularidade tanto na construção do filho-como-problema, a criança incompreendida, quanto no efeito de 
fechamento que, em todos os casos, é centrado na aceitação pelos pais da individualidade dos filhos ou no sucesso dos filhos a partir dessa aceitação. A incompreensão da criança, nesses filmes contemporâneos sobre relações pais e filhos se relaciona necessariamente ao enunciado de que os pais devem aceitar os filhos como eles são, enunciado não está presente nos filmes da década de 1960, nem no livro de 1869 que analisamos nos capítulos anteriores.

Se os filmes, como sustentamos, são discursos que produzem efeitos de governo ou, em outras palavras, se tomarmos o cinema como pedagogia (LOURO, 2000; STEINBERG, 2004), constatamos que uma das formas de tentar conduzir a conduta dos pais pelo cinema é ensinando-os que eles devem aceitar seus filhos como eles são. A busca pela descoberta de uma suposta essência da criança e o apoio nessa descoberta são apresentados, pelos filmes contemporâneos analisados, como ideais de comportamento familiar, que auxiliariam na plena realização e liberdade dos filhos. Essa busca, convertida em norma, orienta, (certamente não sem mediações, mas visa orientar) a conduta dos pais.

Nikolas Rose escreve, em seu livro Inventando Nossos Selfs: psicologia, poder e subjetividade (2011), que

\begin{abstract}
Nós fomos libertados das prescrições arbitrárias de autoridades religiosas e políticas, permitindo, assim, uma série de diferentes respostas à questão de como devemos viver. Mas fomos atados a um relacionamento com novas autoridades, profundamente subjetivadoras porque parecem emanar de nossos desejos individuais de nos realizarmos em nossa vida cotidiana, de esculpir nossas subjetividades, de descobrir quem realmente somos." (ROSE, 2011, p. 33)
\end{abstract}

Essa busca por nossa suposta essência é subjetivadora, uma vez que nos enxergamos enquanto sujeitos por meio dessa questão de uma descoberta e nos relacionamos em família e em sociedade também, em parte, orientados por isso. Ainda, Rose alerta que essa busca nos leva a buscar a ajuda de "experts da alma", de autoridades conselheiras, que nos orientam profissionalmente nessa busca.

Essa figura do psicólogo ou dos especialistas psi em geral, no entanto, aparece apenas no filmes Minha Vida em Cor-de-Rosa, que relaciona a busca de uma suposta essência à uma suposta verdade do sexo, uma orientação sexual e identidade de gênero que deveriam ser descobertas por Ludovic. Nos demais filmes, os especialistas que aparecem e atravessam as famílias fechadas sobre si mesmas são professores ou profissionais de áreas específicas que 
podem enunciar um dom ou uma característica apresentada em estado latente, como uma potência identificada por um indício: a professora de balé identifica que Billy pode ser um gênio (Billy Elliot), o professor de canto percebe que Paula tem um dom (A Família Bélier), a avó profeta identifica que Moana é a escolhida pelo oceano (Moana), Nidhi tem um dom reconhecido pelo irmão, Alberto pelo treinador ( $O$ Grande Dia). Assim, mesmo a presença do psicólogo em Minha Vida em Cor-de-Rosa se justifica, dentro dessa regularidade, como uma profissional especialista em sexualidade que é contratada para modificar o comportamento de Ludovic, mas que termina por reconhecer e apresentar com legitimidade uma essência tida como inelutável.

Não é mais a mãe que compreende a criança por sua natureza maternal ou pela plena devoção à sua função materna. À mãe e ao pai cabe apenas aceitar a natureza da criança e propiciar condições para seus desenvolvimento quando elas se apresentam e são identificadas por um especialista, mesmo que não sejam capaz de compreendê-las. A criança, individualizada desde o nascimento, é incompreendida porque tem uma essência, um dom, uma característica que faz parte de sua essência individual, do núcleo de sua individualidade, mas que, por ser contrário às expectativas da família, não é devidamente reconhecida e estimulada pelos pais.

O sociólogo François de Singly, em seu livro A Sociologia da Família Contemporânea, identifica essa busca como distintiva das normas familiares que se apresentam aos pais desse período contemporâneo ou de uma segunda modernidade:

\footnotetext{
$\mathrm{Na}$ família contemporânea, a criança é dotada de qualidades pessoais desde o nascimento. Os pais não querem criar um filho, o que querem é criar as melhores condições para que a natureza do filho ou da filha possa desenvolver-se. Não têm que impor, têm que descobrir. (SINGLY, 2011, p. 104-5)
}

Cabe aos pais (e aqui, nesse ponto exclusivamente, a norma é a mesma ao pai e à mãe) descobrir a verdade do filho, seu verdadeiro eu, quem ele realmente é. A natureza do filho parece desabrochar espontaneamente, asseguradas as condições ideais de desenvolvimento garantidas pelos pais que apoiam 100\% os filhos.

Esse enunciado presente em todos os filmes analisados produzidos a partir da década de 1990, não se encontra nos filmes da década de 1960 observados no capítulo anterior, nem 
no livro de 1869. No filme A Noviça Rebelde, da década de 1960, vemos sete crianças aprendendo a cantar e até ganhando um prêmio pela performance, mas o canto não é apresentado como um dom individual revelado ou reconhecido e sim como uma habilidade que todos podem desenvolver. No romance vitoriano, lemos um pai dizendo ao filho que determinado comportamento não era a vocação da criança. O fato do pai determinar unilateralmente aquilo que era ou não vocação do filho não contribuia diretamente para a construção discursiva da criança como incompreendida. Em Misunderstood, a construção discursiva da criança incompreendida está relacionada a uma falsa percepção da vivacidade da criança pelo pai, que a compreende como a "falta de coração", como falta de capacidade do filho de sentir remorso e, assim, poder ser juiz de seus próprios atos, ter autocontrole. $\mathrm{O}$ pai temia que o excesso de vigilância o tornasse um "mosca-morta", mas que a falta de vigilância o levasse ao risco de morte. A solução apresentada para tal dilema é a internalização da vigilância, é o autocontrole. Não é à toa, portanto, que o pai atribui tanta importância a esse fato.

Quando saltamos de Misunderstood (1869) para os filmes contemporâneos aqui analisados, vemos uma ruptura. A fala do pai de Humphrey, que, sem constrangimentos, lhe diz: "essa não é sua vocação", é inimaginável nos filmes contemporâneos. Se no livro da inglaterra vitoriana, a vocação do filho era determinada pelo pai, que deve acompanhá-lo de perto, mas deve guiá-lo, formá-lo, possibilitar que tenha autocontrole e determinar sua vocação, agora, aos pais cabe olhar de perto para identificar uma essência, um verdadeiro-eu, uma potência, e aceitar os filhos como eles são. Não são os pais que determinam o melhor percurso formativo para os filhos. São os filhos que, no desabrochar de sua suposta natureza, indicarão aos pais, se eles estiverem atentos aos sinais e aos especialistas que auxiliam a reconhecê-los, o caminho da formação ideal para o desenvolvimento de sua natureza particular.

A predestinação é recolhida do alto dos céus para o interior dos indivíduos na forma de uma natureza particular. Ainda que o destino de cada um só se realize no transcorrer de sua vida, pelos seus atos, pelo contato com o mundo, ele já estaria anunciado, em alguma medida, nas profundezas do ser. Assim, aquilo que Moana está destinada a enfrentar já está 
nela desde o nascimento. Cada criança, uma profecia a ser desvendada; cada criança. um "oceano profundo".

Ao contrário do que observamos nos filmes, porém, Singly argumenta que

A desvalorização relativa do processo de transmissão é conforme este projeto. Para que a criança seja ela própria, deve ter pais que sejam eles próprios, sinceros e autênticos, preocupados sobretudo com o seu desenvolvimento pessoal. (SINGLY, 2011, p. 105).

O desenvolvimento da individualidade dos filhos estaria ligado diretamente, na hipótese do autor, ao desenvolvimento da individualidade dos pais. Nos filmes analisados, com exceção de Pequena Miss Sunshine (DAYTON; FARIS, 2006), no entanto, isso não aparece. Pelo contrário, essa relação, que o François de Singly descreve como característica das famílias contemporâneas ou das famílias da segunda modernidade, aparece, nos filmes, como a de uma oposição. O projeto político do pai de Paula, em A Família Bélier (LARTIGAU, 2014), exigia da filha algo que a atrapalha em sua busca individual; o pai de Moana, no filme homônimo (MUSKER; CLEMENTS, 2016), nega a busca de seu desenvolvimento para proteger a aldeia e a filha após seu melhor amigo morrer afogado nesse processo; o pai de Billy não tem perspectiva nenhuma de deixar a mina de carvão e abre mão da greve para pagar os estudos de Billy (DALDRY, 2001); a mãe de Ludovic, em Minha Vida em Cor-de-Rosa (BERLINER, 1997), abre mão de seus projetos para acompanhar o marido no novo emprego e no novo bairro; o pai de Ludovic, no mesmo filme, perde o emprego por conta do comportamento do filho, mas aceita essa condição ao final, pelo bem da família; nenhuma mãe, à exceção do filme Incompresa (ARGENTO, 2014), tem individualidade. E mesmo nesse filme, isso é apresentado como negativo, como elemento que leva ao abandono da filha. O sacrifício pelos filhos é muito mais presente, nos filmes, do que o exemplo. O silencioso sacrifício da mãe, cuja individualidade sequer é tematizada nos filmes, e o penoso sacrifício dos pais, fonte de quase todo drama.

Portanto, os filmes contemporâneos ensinam os pais ao mesmo tempo a aceitarem os filhos como são e a propiciarem as melhores condições possíveis para o desenvolvimento de uma suposta natureza espontânea dos filhos, mas não o fazem pelo exemplo. A dimensão da imitação, tão presente no livro de Florence Montgomery (1869), agora pouco aparece ou, antes, aparece de forma bastante distinta. Os riscos apresentados às crianças eram justificados 
em Misunderstood pelo fato delas imitarem outros membros da família: o irmão mais novo imita o mais velho e o irmão mais velho imita o pai e as histórias do tio. Nos filmes contemporâneos, os filhos não imitam tanto os pais, ainda que eventualmente alguma cena apresente alguma referência a essa ideia. A teoria de que o Ludovic gosta de se vestir de menina e quer ser menina porque passa tempo demais com a mãe é levantada no filme, mas é apresentada como um conselho popular em meio a outros igualmente falsos. Quem Ludovic imita, do começo ao fim do filme, não é a mãe, é Pam, é a televisão: esse estranho que habita a família.

Há um descompasso entre a norma familiar construída no discurso cinematográfico contemporâneo analisado e aquilo que é chamado por sociólogos como François Singly de família contemporânea. Se, por um lado, o discurso fílmico apresenta uma família que deve aceitar a individualidade do filho, compreendê-lo em suas especificidades e auxiliá-lo a reconhecer sua suposta essência, potencial ou vocação, tal qual a família contemporânea, por outro lado os pais não o fazem pelo exemplo, mas pelo sacrifício, uma vez que não buscam, nesses filmes uma individualidade própria de modo que esse processo possa ser mimetizado pelos filhos. Portanto, ainda que o enunciado central recorrente em todos seja um ideal das família contemporâneas, os filmes reforçam ideais da família moderna, de sacrifício e dedicação total aos filhos.

Pequena Miss Sunshine (DAYTON; FARIS, 2006) é, nesse sentido, uma exceção, uma vez que é o único filme em que a individualidade da criança é construída em paralelo à individualidade dos outros membros da família, cada um buscando seu próprio projeto, mesmo que todos fracassem. O apoio da família à participação fadada ao fracasso de Olive no concurso de Miss Sunshine é construída após o fracasso do pai, que mesmo assim é apoiado pelo avô, a desilusão do tio, que é apoiado pela mãe, e a frustração do irmão, apoiado pelo tio e pela própria Olive. A dimensão do exemplo é construída pela busca de cada membro por seus projetos individuais e não pela legitimidade do projeto em si. O que se coloca em questão é a construção da individualidade por meio de uma busca identitária ligada ao processo de tentar e fracassar e não à validade daquilo que se busca. Assim, o que vemos é uma validação totalmente interna à família, que prescinde da legitimação de especialistas. Ao mesmo tempo, porém, ao apresentar o projeto de Olive de forma irônica como a busca absurda de participar de um concurso de miss mirim em que se vê a sexualização precoce de 
garotas, imposição de estereótipos de beleza e de gênero, constrói-se uma norma ambígua: até que ponto é possível afirmar que se escapa de dependência dos especialistas se o projeto é construído de forma irônica, enfatizando, desde o princípio, que está fadado ao fracasso? Se por um lado, a construção narrativa do filme ensina que o objetivo em si importa muito pouco, por outro lado, a escolha deste objetivo específico pode levar o espectador a problematizar essa aceitação cega.

Em Pequena Miss Sunshine, resgata-se a dimensão do exemplo na família, mas é também neste filme que aparece de forma mais evidente a figura da televisão como esse estranho dentro de casa imitado pelos filhos. Já na cena inicial, a imagem da televisão é refletida nos óculos de Olive enquanto ela assiste ao concurso de Miss América e imita os gesto da vencedora. Se mudarmos um pouco a perspectiva, é possível dizer que desde de o início fomos apresentados aos personagens principais: Olive, a televisão e o concurso.

Figura 9 - Cena inicial do filme Pequena Miss Sunhine em que Olive assiste ao concurso de Miss América na televisão e a imagem é refletida em seus óculos.

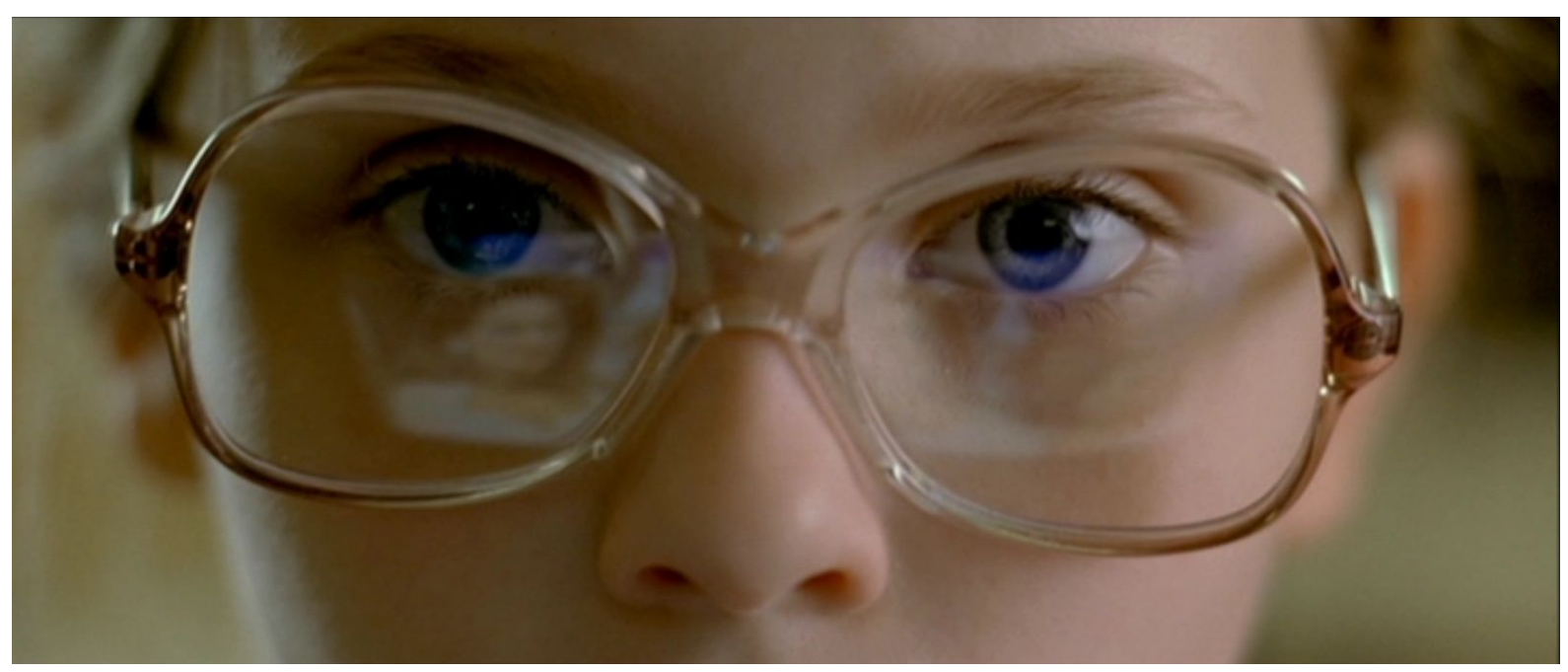

Fonte: print screen do filme Pequena Miss Sunshine. 


\section{CONSIDERAÇÕES FINAIS - TELEVISÃO}

Carlota Boto escreve que, durante o Renascimento, constroem-se algumas estratégias para transformar a criança em aluno, destacando um aspecto civilizador da educação escolar, que também seria uma forma de criar uma distinção de classe. Assim, Boto chama a atenção ao fato de que o modelo que se passava às crianças era um "modelo cultural prévio e anteriormente prescrito". Analisando a obra pedagógica A civilidade pueril de Erasmo, a autora nos conta que os tratados tinham por meta "elencar um conjunto de saberes, de savoir faire, de savoire vivre, que contasse do mundo às crianças, ao mesmo tempo em que configurasse muito precisamente um estilo particular de mundo a ser construído. Tratava-se, portanto, de sumarizar um roteiro prescritivo de civilização." (BOTO, 2009)

Se tomarmos a tese de Neil Postman (1999) sobre o desaparecimento da infância a partir dessa perspectiva, da substituição de um esquema civilizatório previamente estabelecido e transmitido gradativamente, com a cautela do pudor e do segredo que a cultura letrada permite, os filmes contemporâneos analisados se mostram especialmente interessantes. Não para refutar ou confirmar qualquer tese, mas para pensar as tensões que são apresentadas nesses filmes das décadas de 1990 e 2000 entre os projetos apresentados pela família e sobretudo pela escola, preparados previamente por especialistas, e os modelos apresentados por outros agentes mais distantes, via televisão e rádio, e que de certa forma se opõem àqueles da "civilização escolar" (BOTO, 2009).

Em Billy Elliot, o protagonista Billy faz referência aos musicais: "Quem você acha melhor, Fred Astaire ou Ginger Rogers?" (DALDRY, 2001) . Billy também sonha com imagens dos filmes que são apresentadas ao espectador como memórias, fazendo referência aos programas, mas sem que apareça a imagem de um aparelho de televisão. Em Minha Vida em Cor-de-Rosa (BERLINER, 19997), Ludovic sonha que está no mundo de Pam, se refugia no outdoor do programa, brinca com os bonecos de Pam e Ben, sonha que é Pam. Em Pequena Miss Sunshine (DAYTON; FARIS, 2006) essa relação com a televisão é levada ao extremo desde a primeira cena, quando Olive assiste os agradecimentos da miss vencedora de um concurso de beleza e a imagem da televisão é refletida em seu óculos, de modo que vemos as imagens pelos olhos de Olive. Olive rebobina e assiste novamente à cena, imitando 
os gestos. O filme se desenvolve a partir do absurdo projeto, sugerido pela televisão e que une toda a família, de levar essa criança a um concurso de beleza.

Ainda que alguns dos filmes apresentem a televisão como uma possibilidade de referência para uma construção identitária dos filhos estranha aos pais, isso não é apresentado como algo percebido pelas próprias famílias. Essa relação, de qualquer forma, está presente nesses filmes. A televisão, ignorada quase totalmente pelas falas dos personagens, está presente visualmente. As narrativas em questão sugerem que o surgimento de um projeto alheio à família pode ter como influência o contato com referências identitárias externas àquelas da comunidade local via televisão. A televisão aparece como um elemento que permite que a criança escape à família mesmo estando dentro de casa.

Nos filmes Billy Elliot, Minha Vida em Cor-de-Rosa e Pequena Miss Sunshine, o que vemos não são os pais como estorvos, mas a presença da televisão rompendo com o monopólio educativo. Esses três filmes apresentam uma situação próxima daquilo que Maria da Graça Setton chamou de "relação dinâmica" entre mídia, família e escola. De acordo com a autora, as relações entre as "instituições socializadoras e seus agentes" não seriam antagônicas, mas se caracterizariam na contemporaneidade por uma configuração (ela se vale do conceito de Norbert Elias) em que a escola perderia seu monopólio das referências identitárias externas à família para, entre outros agentes, a televisão, o que possibilitaria uma relação da criança com parâmetros não locais e, por definição, multiformes. Assim, "é possível pensar os sujeitos sociais podendo orientar suas práticas e ações, podendo refletir sobre realidade, construí-la e experimentá-la a partir de outros parâmetros que não sejam mais exclusivamente locais, presentes na escola e na família”. (SETTON, 2002).

E se confrontarmos a norma familiar presente em todos os filmes contemporâneos de que os pais devem aceitar os filhos como eles são com a possibilidade de que as pessoas não tenham uma suposta essência a ser descoberta e incentivada pelos pais? E se admitirmos como possível que o desenvolvimento da individualidade das crianças estranhas aos pais possa ser fruto da perda do monopólio da família como referência identitária e não de indícios de uma suposta essência que deveria ser reconhecida? E se levamos essa norma de aceitação cega da individualidade dos filhos ao limite com os pais levando a própria filha a um evento que sexualiza os corpos das crianças e que impõe estereótipos de beleza que 
certamente não contemplam Olive como em Pequena Miss Sunshine? E se tratarmos o suposto dom reconhecido pelos especialistas de cada área como uma forma de governar tanto crianças como pais?

Quais são as consequências se consideramos que o enunciado de uma suposta essência age de forma a substituir um processo formativo civilizatório preestabelecido por um percurso personalizado de certa forma indicado pela própria criança? Não se trata aqui, em hipótese alguma, de defender uma submissão dos filhos à vontade dos pais, o que certamente tem efeitos inadmissíveis para nós, indivíduos modernos. Trata-se apenas de questionar até que ponto a própria forma como se apresenta nossa libertação, a libertação de nossos filhos, não constrói também outras formas de sujeição, para que, tornando-as pensáveis, possamos escolher quais caminhos seguir. E se a profundidade do oceano que é cada criança não estiver ligada à interioridade de uma essência, mas à possibilidade de estabelecer relações? $\mathrm{O}$ fechamento da família sobre si, validando todos projetos de seus membros como processos de uma descoberta, continuaria sendo o ideal de liberdade que buscamos? 


\section{REFERÊNCIAS}

ALTICK, Richard D. "Nineteenth-Century English Best-Sellers: A Third List." Studies in Bibliography, vol. 39, 1986, pp. 235-241.

ARAÚJO, Inácio. Filme mostra proletariado como classe rude. Folha de S. Paulo, 16 mar. 2001.

ARIÈS, Phillipe. História social da família. Rio de Janeiro: Editora Guanabara, 1986.

AQUINO, Júlio Groppa. A família no fogo cruzado da educação contemporânea

[conferência]. CPFL: 2011. Disponível em:

http://www.cpflcultura.com.br/site/?s=julio+aquino. Acessado em 20 dez. 2016.

BAUMAN, Zygmunt. Amor líquido: sobre a fragilidade dos laços humanos. Rio de Janeiro: Zahar, 2004.

- Zygmunt. Vivemos em tempos líquidos. Nada é feito para durar. Revista Istoé

Online. 24 de setembro de 2010. Disponível em: $<$ https://istoe.com.br/102755_VIVEMOS+TEMPOS+LIQUIDOS+NADA+E+PARA+DUR AR+/>. Acesso em: 03 de abril de 2018.

BERGALA, Alain. A hipótese-cinema: pequeno tratado de transmissão do cinema dentro e fora da escola. Rio de Janeiro: Booklink, 2008.

BOTO, Carlota. Civilizar a infância na Renascença: estratégias de distinção de classe. Revista Tempos e Espaços em Educação, v. 2, p. 119-140, jan./jun. 2009.

BORDWELL, David. O cinema clássico hollywoodiano: normas e princípios narrativos. In: RAMOS, Fernão Pessoa (Org.). Teoria contemporânea do cinema: documentário e narratividade ficcional. São Paulo: Senac, 2005. p. 277- 301. Volume 2.

BRASIL. Supremo Tribunal Federal. Ação direta de inconstitucionalidade $n^{\circ}$ 4.277/DF Distrito Federal. Relator: Ministro Ayres Britto. Pesquisa de Jurisprudência, Acórdãos, 05 mai. 2011. Disponível em: < http://redir.stf.jus.br/paginadorpub/paginador.jsp?docTP=AC\&docID=628635>. Acesso em: 16 dez. 2016. 
BRASIL, Câmara dos Deputados. Autor: Dep. Anderson Ferreira. Projeto de Lei PL6.583. Dispõe sobre o Estatuto da Família e dá outras providências. Sala das Sessões, 16 out. 2013. Disponível em: < http://www.camara.gov.br/proposicoesWeb/prop_mostrarintegra;jsessionid=038EE0B762D2 88987067AE870429BC8A.proposicoesWebExterno2? codteor $=1159761 \&$ filename $=$ PL +6583 /2013>. Acesso em: 16 dez. 2016.

COELHO, Marcelo. As dificuldades de ser menino. Folha de S. Paulo, 4 abr. 2001.

CORSO, Diana e Mário. A Psicanálise na Terra do Nunca: ensaios sobre a fantasia. São Paulo, SP: Artmed Editora, 2011.

COSTA, Jurandir Freire. Ordem médica e norma familiar. Rio de Janeiro: Edições Graal, 1989.

DONZELOT, Jacques. A polícia das famílias. Rio de Janeiro: Edições Graal, 1980.

ELIAS, Norbert. A civilização dos pais. In: ELIAS, Norbert. Au delá de Freud: sociologie, psycologie, psychanalise. Paris: Éditions la découverte, 2010. Tradução de Mariana Rocha de Oliveira e Graziela Perosa.

ELLSWORTH, Elizabeth. Modos de endereçamento. In: SILVA, Tomaz Tadeu (Org.). Nunca fomos humanos - nos rastros do sujeito. Belo Horizonte: Autêntica, 2001, p. 07-76.

FISCHER, Rosa Maria Bueno. Pequena Miss Sunshine: para além de uma subjetividade exterior. Pro-Posições. Campinas, v. 19, n. 2, p. 47-57, ago. 2008.

FOUCAULT, Michel. Os anormais: curso no Collège de France (1974-1975). São Paulo: Martins Fontes, 2001

A Arqueologia do Saber. Rio de Janeiro: Forense Universitária, 2014.

A ordem do discurso. In: Gênese e estrutura da antropologia de Kant e A ordem do discurso. Coleção Folha: Grandes nomes do pensamento, v. 6. São Paulo: Folha de S. Paulo, 2015a.

. Vigiar e Punir. Petrópolis: Editora Vozes, 2015b.

HALL, Catherine. Sweet Home. In: PERROT, Michelle. História da vida privada, 4: Da Revolução Francesa à Primeira Guerra, São Paulo: Companhia das Letras, 2009. 
HARRIS, Marl. Cenas de uma revolução: o nascimento da nova Hollywood. Porto Alegre, RS: L\&PM, 2011.

KELLNER, Douglas. A cultura da mídia - estudos culturais: identidade e política entre o moderno e o pós-moderno. Bauru: EDUSC, 2001.

MARCELLO, Fabiana de Amorim; FISCHER, Rosa Maria Bueno. Tópicos para Pensar a Pesquisa em Cinema e Educação. Educação \& Realidade, v. 36, n. 2, p. 505-519, 2011.

MCLEER, Anne. Practical Perfection? The Nanny Negotiates Gender, Class and Family Contradictions in 1960s Popular Culture. In: NWSA Journal, Vol. 14, n. 2, 2002, p. 80-101. MONTGOMERY. Florence. Incompreendido. São Paulo: Primavera, 1960.

Misunderstood. London: Richard Bentley, 1869.

ROSE, Nikolas. Inventando nossos selfs: psicologia, poder e subjetividade. Petrópolis: Vozes, 2011.

ROSENTHAL, L. "Misunderstood: A Victorian Children's Book for Adults." Children's Literature, vol. 3 no. 1, 1974, pp. 94-102.

POSTMAN, Neil. O Desaparecimento da Infância. Rio de Janeiro: Grafhia Editorial, 1999. SCHWARCZ, Lilia. Como viver 'feliz para sempre' (e sem um príncipe encantado). Nexo Jornal, 13 de fevereiro de 2017.

SETTON, Maria da Graça Jacintho. Família, escola e mídia: um campo com novas configurações. Educação e Pesquisa, São Paulo, v. 28, n. 1, p. 107-116, jun. 2002.

SINGLY, François de. Sociologia da família contemporânea. Rio de Janeiro: Editora FGV, 2007.

STEINBERG, Shirley R., KINCHELOE, Joe L. (orgs.). Cultura Infantil: a construção corporativa da infância. Rio de Janeiro: Civilização Brasileira, 2004. 
FILMES

ARGENTO, Asia. Incompreendida (Incompresa). Itália, 2014 (102 min).

BERLINER, Alain. Minha Vida em Cor-de-Rosa (Ma Vie en Rose). França, 1997 (89 min).

COMENCINI, Luigi. Quando o Amor é Cruel (Incompreso - Vita col figlio). Itália, 1966 (99 $\min )$.

DALDRY, Stephen. Billy Elliot. Inglaterra, 2001 (110 min).

DAYTON, Jonathan; FARIS, Valerie. Pequena Miss Sunshine (Little Miss Sunshine). EUA, 2006 (101 min).

LARTIGAU, Eric. A Família Bélier (La Famille Bélier). França, 2014 (105 min).

STEVENSON, Robert. Mary Poppins. EUA, 1964 (139 min).

MUSKER, John; CLEMENTS, Ron. Moana: um mar de aventuras (Moana). EUA, 2016 (107 $\mathrm{min})$.

PLISSON, Pascal. O Grande Dia (Le Grand Jour). França, 2015 (86 min).

WISE, Robert. A Noviça Rebelde (The Sound of Music). EUA, 1965 (174 min). 